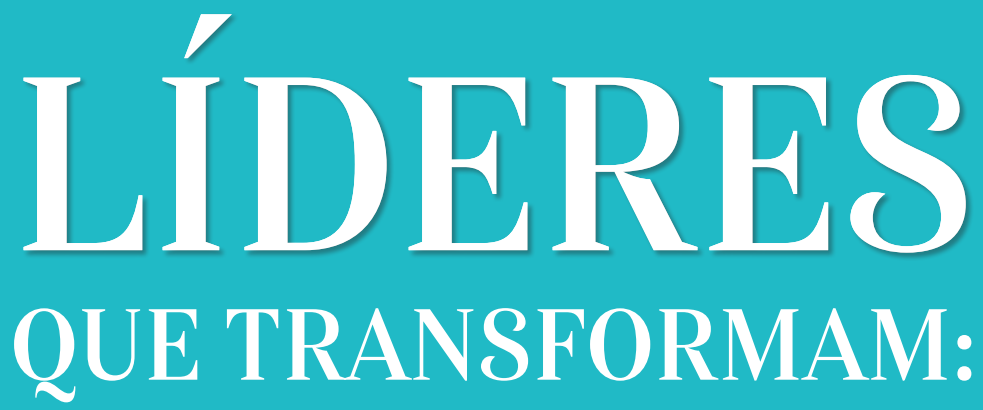

Novos Paradigmas de Gestão na Educação

Dolores Raissa Teixeira Cunha Iury Torquato de Almeida Luciana Mascena Silva Maria Eliene Magalhães da Silva Rita Cristiane de Oliveira Gomes Sueli dos Santos Leitão |Organizadores/as|

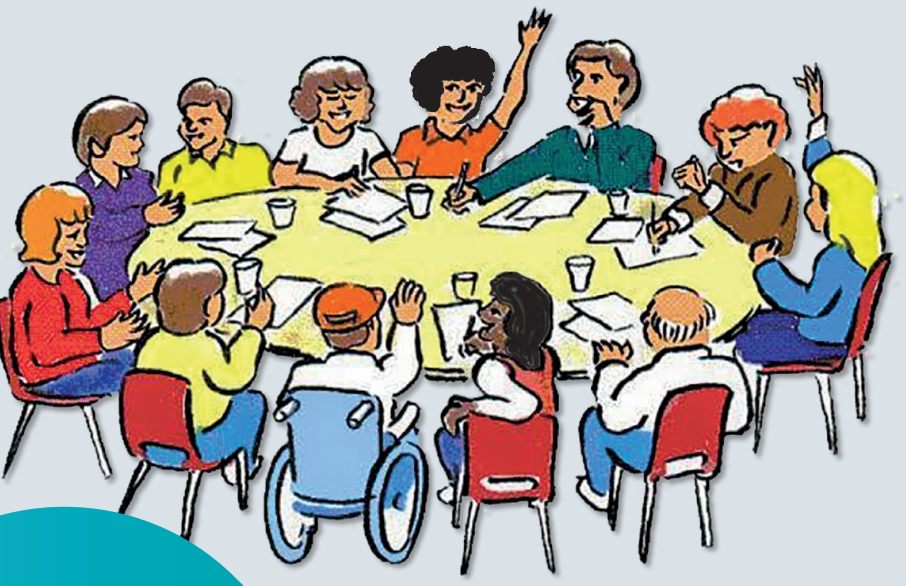




\section{LÍDERES QUE TRANSFORMAM: NOVOS PARADIGMAS DE GESTÃO NA EDUCAÇÃO}

(C) 2021 Copyright by Dolores Raissa Teixeira Cunha, Iury Torquato de Almeida Luciana Mascena Silva, Maria Eliene Magalhães da Silva, Rita Cristiane de Oliveira Gomes e Sueli dos Santos Leitão (Orgs.)

IMPRESSO NO BRASIL / PRINTED IN BRAZIL EFETUADO DEPÓSITO LEGAL NA BIBLIOTECA NACIONAL TODOS OS DIREITOS RESERVADOS

DRA. AIALA VIEIRA AMORIM | UNILAB DR. ALUÍSIO MARQUES DA FONSECA | UNILAB DRA. ANA MARIA IORIO DIAS |UFC DRA. ANA PAULA STHEL CAIADO | UNILAB DRA. ANTONIA IEDA DE SOUZA PRADO | UNINASSAU DR. ANTÔNIO ROBERTO XAVIER | UNILAB DR. CARLOS MENDES TAVARES | UNILAB DR. CHARLITON JOSÉ DOS SANTOS MACHADO | UFPB DR. EDUARDO FERREIRA CHAGAS | UFC DR. ELCIMAR SIMÃO MARTINS | UNILAB DRA. ELISÂNGELA ANDRÉ DA SILVA COSTA | UNILAB DR. ENÉAS DE ARAÚJO ARRAIS NETO | UFC DR. FRANCISCO ARI DE ANDRADE | UFC DR. GERARDO JOSÉ PADILLA VÍQUEZ | UCR DRA. HELENA DE LIMA MARINHO RODRIGUES ARAÚJO | UFC DR. JAVIER BONATTI | UCR DR. JOSÉ BERTO NETO | UNILAB

\section{Conselho Editorial}

DR. JOSÉ GERARDO VASCONCELOS | UFC DRA. JOSEFA JACKLINE RABELO | UFC DR. JUAN CARLOS ALVARADO ALCÓCER | UNILAB DRA. LIA MACHADO FIUZA FIALHO | UECE DRA. LÍDIA AZEVEDO DE MENEZES | UVA DRA. LIVIA PAULIA DIAS RIBEIRO | UNILAB DR. LUÍS MIGUEL DIAS CAETANO | UNILAB DR. LUIS TÁVORA FURTADO RIBEIRO | UFC DRA. MÁRCIA BARBOSA DE SOUSA | UNILAB DRA. MARIA DO ROSÁRIO DE FÁTIMA PORTELA CYSNE | UNILAB DR. MICHEL LOPES GRANJEIRO | UNILAB DR. OSVALDO DOS SANTOS BARROS | UFPA DRA. REGILANY PAULO COLARES | UNILAB DRA. ROSALINA SEMEDO DE ANDRADE TAVARES | UNILAB DRA. SINARA MOTA NEVES DE ALMEIDA | UNILAB DRA. VANESSA LÚCIA RODRIGUES NOGUEIRA | UNILAB

Projeto Gráfico e Capa | Carlos Alberto Alexandre Dantas Revisão | Dolores Raissa Teixeira Cunha

Dados Internacionais de CatalogaçÃo na PublicaÇÃo (CIP) Bibliotecária: Regina Célia Paiva da Silva - CRB 1051

L714 Líderes que transformam: novos paradigmas de gestão na educação / Dolores Raissa Teixeira Cunha; Iury Torquato de Almeida; Luciana Mascena Silva...[et al.], (orgs). - Maracanaú: Imprece, Faculdade Cesma de Maracanaú 2021.

324p.il. 14 cm x 21 cm. (Coleção Facesma, v. 1)

Incluem: imagens e gráficos

ISBN E-book: 978-65-87212-62-3

DOI:

1. Inteligência Emocional - Educação. 2. Avaliação Educacional. 3. Covid-19. 4. Pandemia. 5. Silva, Maria Eliene Magalhães da. 6. Gomes, Rita Cristiane de Oliveira. 7. Leitão, Sueli dos Santos. I. Título.

CDD. 370.153 


\author{
Dolores Raissa Teixeira Cunha \\ Iury Torquato de Almeida \\ Luciana Mascena Silva \\ Maria Eliene Magalhães da Silva \\ Rita Cristiane de Oliveira Gomes \\ Sueli dos Santos Leitão \\ |Organizadores/as|
}

\title{
LÍIDERES \\ QUE TRANSFORMAM: \\ Novos Paradigmas de Gestão na Educação
}

FACULDADE CESMA DE MARACANAÚ

\author{
Coleção Facesma \\ Volume 1
}

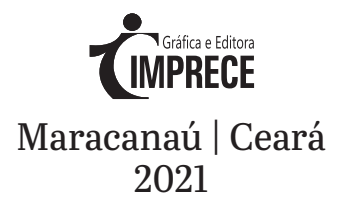




\section{FACESMA}

\section{FACULDADE CESMA DE MARACANAÚ CNPJ: 19.059.424/0001-50 \\ Credenciada pelo MEC - Portaria № 89, de 14 de janeiro de 2019}

Izabel Cristina de Oliveira Pires | Direção Geral Rita Cristiane de Oliveira Gomes | Direção Acadêmica Mayara Cesarina Gomes de Sousa | Mantenedora Luciana Mascena Silva | Secretaria Acadêmica Valéria Alves da Silva | Coordenadora do Curso de Pedagogia Iury Torquato | Coordenador do Curso de Administração

Luis Paulo Gomes de Sousa | Diretor de Marketing Fca Jeane de Paiva Jorge | Dirora de Recursos Humanos Nely Germano | Diretora do Departamento Financeiro Diego do Vale Peixoto | Departamento de Tecnologia Amanda Távora de Souza Tomaz | Assessora Pedagógica Mylene Mariana de Sousa Alencar | Assessora Pedagógica Maria Isabelle Barroso Machado | Assessora Pedagógica Irene Lopes de Sousa | Almoxarifado 


\section{SUMÁRIO}

APRESENTAÇÃO : 11

Dolores Raissa Teixeira Cunha

Luciana Mascena Silva

Iury Torquato de Almeida

Maria Eliene Magalhães da Silva

Rita Cristiane de Oliveira Gomes

Sueli dos Santos Leitão

PREFÁCIO $\cdot 13$

Maria Eliene Magalhães da Silva

CONTRIBUIÇÕES DA DOCÊNCIA NOS ASPECTOS EMOCIONAIS E DE

APRENDIZAGEM EM TEMPOS DE PANDEMIA: PROCESSO DE ALFABETIZAÇÃO EM

CRIANÇAS DE UMA ESCOLA PÚBLICA EM MARACANAÚ-CE $\cdot 15$

Aretuza Alves Oliveira

Gilberto Emerson Nobre Sampaio

Rosa Maria Araújo Peixoto Maia

Maria Eliene Magalhães da Silva

LIMITES E POSSIBILIDADES DO ENSINO REMOTO NA EDUCAÇÃO DE JOVENS

E ADULTOS (EJA DA EMEIEF JOSÉ ASSIS DE OLIVEIRA NO MUNICÍPIO DE

MARACANAÚ - CE) - 28

Beatriz Dias Sousa

Edinir Silva Teixeira

Márcio Roque Cordeiro

Maria Eliene Magalhães da Silva

A ESCOLA BRAZ RIBEIRO DIANTE DA VULNERABILIDADE SOCIAL: POSSIBILIDADES DE APRENDIZAGEM DURANTE O PERÍODO PANDÊMICO * 44

Francisca de Fátima Guilherme de Lima

Israel Monteiro Dantas

Tatiany Freitas Correia Santana

Maria Eliene Magalhães da Silva 


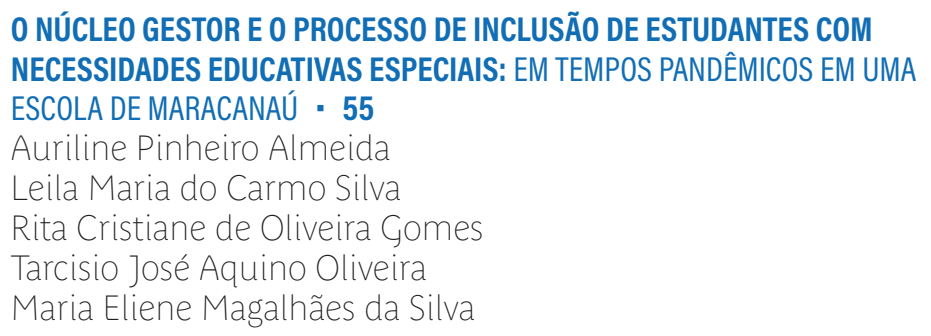

OS DESAFIOS DA GESTÃO ESCOLAR EM TEMPO DE PANDEMIA: AÇÕES

EDUCACIONAIS E PSICOSSOCIAIS NA PERSPECTIVA DE APOIAR PROFESSORES E COMUNIDADES EM ESCOLAS DE MARACANAÚ - CEARÁ · 70

Nadma Maria Soares de Freitas

Patrícia ]o Montaldo de Macedo

Sissi Leyla dos Santos Mendes

Maria Eliane Magalhães da Silva

O DOCENTE E SUAS EMOÇÕES: NA BUSCA DE UMA METODOLOGIA EM MEIO A PANDEMIA $\cdot 85$

Adriana Raisa Alves de Oliveira

Jailson Moreira Lopes

Mariana Rodrigues Torres

lury Torquato de Almeida

A FAMÍLIA E 0 ENSINO REMOTO: OS DESAFIOS EDUCACIONAIS E EMOCIONAIS EM TEMPOS DE PANDEMIA, NA VISÃO DAS FAMÍLIAS NAS AULAS REMOTAS - 105

Almir Pereira dos Santos

Aurileda de Lima

Jenivando Lira Braz

lury Torquato de Almeida

GESTÃO ESCOLAR DEMOCRÁTICA E PARTICIPATIVA: DESAFIOS PARA GARANTIA DO CUMPRIMENTO INTEGRAL DO ECA * 123

Ana Maria Venancio da Silva Helayne Vieira Correa Coêlho

Maria Liduina Venancio Almeida

Lore Ana Terceiro Persch

Iury Torquato de Almeida 
ANÁLISE DA INTELIGÊNCIA EMOCIONAL NO AMBIENTE DE TRABALHO: COMO A INTELIGÊNCIA EMOCIONAL PODE INFLUENCIAR A VIDA DO TRABALHADOR - 130 Antônia Alcir Santos Ramos

Joanna Paula Façanha Mesquita

Lívia Maria Lopes Holanda

Iury Torquato de Almeida

RELATOS DE EXPERIÊNCIA DA PANDEMIA: VIVÊNCIAS DE UMA ESCOLA HUMANIZADA $\cdot 140$

Francisca Edirene de Sousa Mourão

Francica Luzia da Silva Martins

Priscila Holanda Nogueira

lury Torquato de Almeida

O DESENVOLVIMENTO DA INTELIGÊNCIA EMOCIONAL NA EDUCAÇÃO INFANTIL:

UMA CONSTRUÇÃO POSSÍVEL NO ENSINO REMOTO • 149

Maria Leidiane de Sousa Leite

Moacir Rodrigues da Silva

Walcineide Viana Barbosa

Iury Torquato de Almeida

\section{A PANDEMIA E SEUS IMPACTOS NO AGRAVAMENTO DE DISTÚRBIOS} SOCIOEMOCIONAIS EM DOCENTES E DISCENTES - 167

Raquel Matias Costa Queiros

Gabia Cavalcante Lima

Lia de Queiróz Ferreira

Iury Torquato de Almeida

IMPACTOS EMOCIONAIS NA PRÁTICA DOS DOCENTES: RECOMEÇAR E AVANÇAR EM TEMPOS DE PANDEMIA * 181

Maria Rozangela Mourão Miranda Vasconcelos

Maria Virlânia Teixeira de Queirós

Luís Gonzaga Barbosa de Sousa

Rita Cristiane de Oliveira Gomes

Iury Torquato de Almeida 
OS DESAFIOS DOCENTES NO ENSINO REMOTO EM TEMPOS DE ISOLAMENTO SOCIAL SOB O OLHAR DA GESTÃO - 194

Antônia Wilma de Oliveira Andrade Santos

Francisca Esmênia de Souza Teixeira

Káthia Cyléa Meneses Oliveira

Luciana Mascena Silva

INTELIGÊNCIA EMOCIONAL: EXPERIÊNCIAS EXITOSAS DE PROFISSIONAIS DA EDUCAÇÃO, SUPERANDO OS MEDOS E AS EXPECTATIVAS ENTRE QUEM ENSINA E QUEM APRENDE NO PERÍODO PANDÊMICO * 208

Andréa Leal Dias

Anita Lima Figueiredo

Francisca Lúcia da Silva

Luciana Mascena Silva

0 GESTOR ESCOLAR COMO CUIDADOR: DESAFIOS VIVENCIADOS NA COMUNIDADE ESCOLAR NO IMPACTO DA COVID -19 $\cdot 224$

Emília Régia Venâncio Gomes

Fransilvia Barroso Machado

Nivea Maria Costa Vieira

Rita Cristiane de Oliveira Gomes

Luciana Mascena Silva

REFLEXÃO DOCENTE E A IMPORTÂNCIA DA INTELIGÊNCIA EMOCIONAL NA EDUCAÇÃO DE JOVENS E ADULTOS DURANTE 0 ENSINO REMOTO • 236

Francisca Rousane Sales de Oliveira Andrade

Isabel Cristina da Silva Martins

Maria do Socorro de Melo Gonzaga

Nely Germano

Luciana Mascena Silva

OS DESAFIOS DA GESTÃO ESCOLAR NO ENSINO REMOTO DURANTE O PERÍODO PANDÊMICO $\cdot 256$

Natália Maria Martins Moreira

Sheyla Maria Mota Meireles

Sílvia Helena Linhares Coelho da Silva

Luciana Mascena Silva 


\section{ABSENTEÍSMO ESCOLAR DE DISCENTE NO ENSINO REMOTO DURANTE A}

PANDEMIA - COVID19 - 268

Sônia Regina Sena de Souza

Valdira Almeida Monteiro

Romana Fernandes Ferreira

Luciana Mascena Silva

TIPOS DE TEMPERAMENTOS PRIMÁRIOS E SEUS REFLEXOS NO ENSINO-

\section{APRENDIZAGEM - 293}

Daniel Bezerra Bernardino

Izabel Cristina de Oliveira Pires

Valéria Alves da Silva

Luciana Mascena da Silva

A AFETIVIDADE E A INTELIGÊNCIA EMOCIONAL COMO ELEMENTOS DE UMA GESTÃO EDUCACIONAL HUMANIZADA COM VISTAS À APRENDIZAGEM

SIGNIFICATIVA $\cdot 306$

Yana Mara Lessa Bernardo

Maria Marylene Ferreira Farias

George Lopes Valentim

Luciana Mascena Silva

Rita Cristiane de Oliveira Gomes

A GESTÃO ESCOLAR EM MEIO A PANDEMIA DA COVID 19: DESAFIOS DO ENSINO APRENDIZAGEM NO CONTEXTO REMOTO $\cdot 324$

Mara Rubia de Araújo Dantas

Rita de Cassia Lopes Gomes

Rosangela Cosmo Batista

lury Torquato de Almeida

EDUCAÇÃO EM TEMPOS PANDÊMICOS: DESAFIOS SOCIAIS E EMOCIONAIS E OS IMPACTOS DE AÇÕES SOCIAIS NO PROCESSO DE ENSINO APRENDIZAGEM NA EMEIEF JOSÉ ASSIS DE OLIVEIRA (MARACANAÚ-CE) · 340

Antônio Flávio de Sousa

Cristiane Silva Lima

Francisca Ticiane Gondim da Costa Jales

Rita Cristiane de Oliveira Gomes

lury Torquato de Almeida 



\title{
APRESENTAÇÃO
}

\author{
Dolores Raissa Teixeira Cunha \\ Luciana Mascena Silva \\ lury Torquato de Almeida \\ Maria Eliene Magalhães da Silva \\ Rita Cristiane de Oliveira Comes \\ Sueli dos Santos Leitão
}

O volume 01 Lideres que Transformam: Novos paradigmas de gestão na educação, da coleção Facesma, aborda a temática da Inteligência Emocional, que referencia a inspiração da professora Sueli Leitão, na disciplina Assessment, Coaching e Mentoring do MBA em Gestão Educacional Pública e Privada da FACESMA - Faculdade Cesma de Maracanaú.

Este livro nasceu a partir do incentivo da referida professora em seu valoroso trabalho junto à turma de 2021, ao provocar o protagonismo literário dos alunos e alunas para juntos escrevermos as nossas práticas na gestão educacional. Uma pretensão rapidamente mobilizada em ação pela professora Cristiane Oliveira, diretora da FACESMA, que com sua visão empreendedora, dedicou todo o apoio, incentivo e recursos necessários para que chegássemos à publicação desta obra. Entre seus feitos, está a reunião de um time de profissionais de excelência na área da educação, como organizadores desta coletânea, e que dedicaram arduamente seus saberes para a construção do conhecimento coletivo, aqui ofertado aos nossos leitores. A professora Maria Eliene, que ministrou a disciplina de Metodologia Científica, vem contribuindo neste feito literário no estado do Ceará como em todo Brasil com outras literaturas acadêmicas. Nestas trilhas foram envolvidas outras 
organizadoras e um organizador, Cristiane de Oliveira Gomes na coordenação e direção junto aos demais organizadoras e organizador, Luciana Mascena Silva, no sentido de orientar e organizar a obra, Iury com sua experiência que trouxe do doutorado, Raissa no campo da revisão geral.

Assim, além de desenvolvermos nossos alunos e alunas nas práticas do mundo acadêmico, imortalizamos por meio da escrita, nossas vivências profissionais na educação, levando para o mundo reflexões, aprendizados e ações que contribuíram e contribuirão com a adoção de novas formas de agir, pensar e sentir o ato de ensinar. Não temos aqui, a pretensão de transferir conhecimento, mas de apresentar uma aventura criadora, onde tornamos viável a aceitação de novos paradigmas, que nos traz esperança de um novo alvorecer, ainda que em tempos tão desafiadores.

É nessa esperança do aprender e ensinar, que esta coleção nos motivará, tornando real o registro de nossos saberes e fazeres nas escolas e na FACESMA, diante do que hoje vivemos no cenário político, educacional, econômico e social, que nos impulsionam a vivenciar rupturas, descobertas, mudanças, inovações, diálogos, discussões e quebra de paradigmas.

Neste contexto, emergem nossas belas escritas, nas quais relatamos os desafios apresentados e as respostas adotadas no enfrentamento à pandemia da Covid-19 (SARS- CoV-2), em que nós, docentes e discentes, de forma coletiva vivenciamos mudanças e inovações no formato online, sobre às quais dedicamos a construção desta obra, tornando-nos autores e autoras de novos paradigmas na gestão educacional. 


\section{PREFÁCIO}

Maria Eliene Magalhães da Silva?

A presente obra, organizada com profissionais da educação da Facesma (Faculdade Cesma de Maracanaú) e artigos do corpo discente da turma nos traz a reflexão que nos instiga a repensar nossas práticas no novo momento pandêmico por conta do Covid-19.

Ao meio de tantas mudanças, perdas de familiares, amigos e amigas, nestes dois anos de distanciamento nos reinventamos juntos, com orientações a distância, mas, sobretudo fazendo acontecer nossos conhecimentos e aprendizados com nossos alunos que aprendem e nos ensinam de repente, construindo assim uma educação democrática e igualitária. "Não existe docência sem discência." "Se a educação sozinha não transforma a sociedade, sem ela tampouco a sociedade muda." Paulo Freire.

Foram dias desafiadores, mas sobretudo, dias de luta para vencermos e estarmos na literatura acadêmica a abordar nossos trabalhos na faculdade, no universo da educação através desta valorosa obra.

O volume 01, intitulado: Lideres que transformam: novos paradigmas de gestão na educação, compõe a coleção: Facesma (Faculdade Cesma de Maracanaú), que aborda resultados da disciplina em Assessment, Coachong e Metoring do MBA em Gestão

1 Professora da Facesma (Faculdade Cesma de Maracanaú); Doutoranda em Ensino pela UFC; Mestra em Educação pela UFC; Professora concursada dos municípios de Caucaia e São Gonçalo do Amarante. 
Educacional no Setor Público e Privado da Facesma ministrada por nossa querida professora Sueli Leitão.

A mola inspiradora que veio de nossa querida diretora acadêmica, organizadora, professora Rita Cristiane de Oliveira Gomes, que articulou junto com os demais organizadores a demanda aqui citada.

Para isso, a professora Cristiane Oliveira, buscou na disciplina de Metodologia da Pesquisa Cientifica, ministrada pela Professora Eliene Magalhães, organizadora e orientadora dos artigos juntamente com o professor Dr. Iury Torquato de Almeida e a professora doutoranda Luciana Mascena Silva.

Ressalto ainda o papel importante na organização da nossa querida professora revisora geral Dolores Raissa Teixeira Cunha, que esteve sempre junto conosco nessa empreitada.

Com isso, relato aqui a colcha de retalhos que formamos para juntos organizarmos esta bela obra. Nossos acadêmicos deram seu melhor, com isso e através da Facesma (Faculdade Cesma de Maracanaú) nosso trabalho torna-se in memoriam suas práxis pedagógica na gestão.

Os artigos que compõem os capítulos desta obra trazem diferentes situações, desde sala de aula, complexidade no campo emocional, gestão escolar e família abordada em momentos pandêmica e de mudanças no contexto geral da educação no Brasil e no mundo.

Queremos desde já trazer com isso novos paradigmas que nos remota há um trabalho dentro dessas áreas que traz cada artigo e nas práticas educacionais aqui citadas no livro. 


\section{CONTRIBUIÇÕES DA DOCÊNCIA NOS ASPECTOS EMOCIONAIS E DE APRENDIZAGEM EM TEMPOS \\ DE PANDEMIA: PROCESSO DE ALFABETIZAÇÃO \\ EM CRIANÇAS DE UMA ESCOLA PÚBLICA EM \\ MARACANAÚ-CE \\ Aretuza Alves Oliveira \\ Gilberto Emerson Nobre Sampaio² \\ Rosa Maria Araújo Peixoto Maia ${ }^{3}$ \\ Maria Eliene Magalhães da Silva ${ }^{4}$}

\section{Considerações iniciais}

O presente artigo apresenta uma análise das contribuições do trabalho da equipe docente das turmas de 2.0 ano da EMEIEF Governador César Cals de Oliveira Filho como facilitadora e acompanhante do processo de alfabetização de alunos. A escola é uma instituição pública do município de Maracanaú-CE. O aspecto a ser

1 Especialista em Ensino de História e Cultura Afro-brasileira e Indígena/UVA e Gestão e Coordenação Escolar/FACPED. Graduada em Pedagogia/UFC. Graduanda em Psicologia/UNIFOR. Professora efetiva da Educação Básica do Município de Maracanaú/CE. E-mail: aretuzalves@gmail.com

2 Especialista em Gestão Escolar: administração, supervisão e orientação/Faculdade Única. Graduado em Pedagogia/UFC. Professor efetivo da Educação Básica do Município de Maracanaú/ CE. E-mail: gilberto.ens@gmail.com

3 Graduada em Letras Português/Inglês - UECE; Especialista em Gestão e Coordenação EscolaR - FAPSS; Professora do município de Maracanaú/CE E-mail: rosmariaaaraujo45@gmail.com

4 Graduada em Ciências da Religião - ICRE; Graduada em Pedagogia - UVA; Graduada em História UVA; Graduada em Letras/Português - UFC; Especialização em psicopedagogia - UFC; Especialização em Ensino religioso - FINOM; Especialização em História para Formação de Professores de Quilombos - UFC; Mestra em Educação - UFC; Professora de Caucaia e São Gonçalo do Amarante; E-mail: elienemariajacyra@gmail.com 
analisado é o trabalho de emoções frente ao período pandêmico em um grupo de alunos imersos na alfabetização, no contexto em que as estruturas emocionais estão abaladas. Este estudo visa contribuir, de alguma forma, para a melhoria de práticas pedagógicas no que diz respeito ao tratamento de emoções no processo educativo.

A escola hoje é compelida a ser uma instituição de transmissão de conteúdos estipulados e previamente selecionados, geralmente transmitidos de maneira tradicional, privilegiando mais o pensamento lógico e deixando a sensibilidade humana em segundo plano, como destaca Santo (2000), que diz que vivemos um momento de transição paradigmática, por isso, há uma necessidade de mudança da forma de pensar a escola, de promoção da postura mais integradora e de trabalho das emoções, equilibrando assim as necessidades quantitativas com as necessidades qualitativas.

No contexto da pandemia da Covid-19, em que o mundo teve que se ordenar socialmente, os alunos saíram do espaço físico da escola e migraram para as salas de aulas virtuais devido ao isolamento social. Essa migração levou os educadores a um desafio maior, estreitar relações de aspectos emocionais de maneira remota, com a interação limitada a telas e bate-papos. Esse contexto educacional afetou muito a aprendizagem dos alunos, o foco deste estudo. Sabemos que diante de tantas notícias e da taxa de pessoas infectadas, a pandemia assusta e cria nas pessoas sentimentos de medo, angústia, ódio, etc. Harari (2020) destaca que para conter os avanços das infecções, houve uma imposição de isolamento social no mundo todo, isso deixou as pessoas confusas e perdidas com as informações que, em geral, eram de- 
sencontradas e ainda sem tanta comprovação científica, visto que os estudos ainda estão em progresso.

A humanidade ainda sofre sem uma liderança mundial ou instituição capaz de orientar e guiar, pois, tudo ainda é muito novo. Ao pensar em isolamento social, Henrique (2020) destaca que estar em casa não é mais, necessariamente, um isolamento social, mas isolamento físico, pois diante do contexto tecnológico em que estamos, diferente de períodos pandêmicos do passado, a comunicação não deixou de existir, o ciberespaço substituiu os espaços físicos e tornou a socialização mais rápida e abrangente com uso de equipamentos portáteis que tornaram as interações virtuais em tempo real. Sem esse contato físico, Preciado (2020) salienta que ao passo em que o contato físico foi se afastando, as interações digitais foram sendo fomentadas e aceleradas, o que dificultou um trabalho mais qualitativo frente às emoções.

No contexto educacional da escola observada, os alunos iniciaram o ano de 2020 com o ensino presencial sendo afastados com a explosão de casos no Brasil no início daquele mesmo ano. Tanto alunos como professores ficaram em casa à espera de uma orientação superior sobre como se daria o processo de ensino a partir da nova realidade, isso gerou, de início, muita tensão pela demora na elaboração de um plano de ações. Posteriormente, um novo modelo foi apresentado, os grupos de WhatsApp se tornariam as novas salas de aulas, o quadro substituído por videoaulas, 'podcast' e todos os recursos que a tecnologia pode oferecer. De imediato essa nova ordenação de trabalhos causou muito impacto, pois segregou alunos com condições financeiras mais precárias. 
A relação entre as ameaças provenientes da desigualdade social e as respostas afetivas dos que a elas se assujeitam compõe um processo psicológicopolítico poderoso à reprodução da desigualdade, que meu núcleo de pesquisa (Nexin) conceitua de sofrimento ético-político. Assim fazemos para distingui-lo do sofrimento ontológico a que todos os seres vivos estão sujeitos, ao qual se soma (SAWAIA, 2010, p. 370).

Segundo a professora entrevistada, cerca de $30 \%$ da turma está fora desse novo sistema, uma parte deles ainda buscam algumas folhas impressas na escola para fazerem as atividades, uma maneira encontrada para diminuir os danos causados, mas que, segundo a mesma, não garante um acompanhamento mais específico para esses alunos.

Considerando os aspectos metodológicos, realizamos entrevistas como ferramenta de pesquisa em educação, com as professoras das turmas de 2.0 ano. Fizemos um levantamento dos desafios enfrentados e de como eles foram trabalhados pelos atores envolvidos, bem como as ações de apoio ao corpo docente, famílias e alunos. As entrevistas aconteceram de maneira remota e isoladas, para assim ter mais fidedignidade à realidade da escola.

Este artigo propõe compreender as contribuições da docência e da gestão escolar no acompanhamento de aspectos emocionais e do processo de aprendizagem escolar. Especialmente no que se refere à sua atuação na identificação e acompanhamento das crianças nos anos iniciais do Ensino Fundamental em relação ao processo de aprendizagem e suas implicações emocionais durante a pandemia de COVID-19.

A metodologia utilizada neste trabalho foi a entrevista individual em profundidade, "técnica qualitativa 
que explora um assunto a partir da busca de informações, percepções e experiências de informantes para analisá-las e apresentá-las de forma estruturada” (Duarte e Barros, 2005, p. 62).

Utilizamos como instrumento de pesquisa um roteiro de entrevistas semiabertas e tivemos todo o cuidado e postura que este trabalho exige. As entrevistas foram realizadas tendo como guia as perguntas elaboradas pelos alunos sob a supervisão do professor orientador.

Em relação ao embasamento teórico para a entrevista propriamente dita, usamos os ensinamentos de Duarte e Barros para conduzir as entrevistas semiabertas, levando sempre em conta que "as questões, sua ordem, profundidade, forma de apresentação, dependem do entrevistador, mas a partir do conhecimento e disposição do entrevistado, da qualidade das respostas, das circunstâncias da entrevista" (2005, p. 66).

Fizemos as entrevistas com duas profissionais da escola, em função de suas experiências com a área investigada. Ademais, em relação aos resultados, transcrevemos as entrevistas gravadas, analisamos e interpretamos os dados obtidos. Em relação aos dados das entrevistadas, todas as informações serão utilizadas apenas para contexto acadêmico, portanto, seus nomes serão mantidos em anonimato, não havendo risco de serem divulgados em nenhuma circunstância.

Conforme o aprofundamento de nossa pesquisa a respeito das áreas escolhidas, fizemos leituras de obras que colaboraram e embasam cientificamente o nosso trabalho.

Durante as entrevistas realizamos perguntas relacionadas às contribuições de cada área investigada 
em relação ao processo de aprendizagem e as emoções em crianças na fase da aquisição da leitura e escrita.

Algumas perguntas foram adaptadas respeitando a particularidade de atuação de cada profissional e iremos apresentar os resultados das entrevistas e das pesquisas bibliográficas em três pontos mais específicos: trilhas, histórico da escola e comunidade; aspectos emocionais e cognitivos $x$ Ensino remoto no processo de alfabetização; análise dos resultados.

\section{Trilhas, histórico da escola e comunidade}

A escola se localiza no bairro Alto Alegre, bem próxima à divisa dos municípios de Maracanaú e Fortaleza; o bairro está em crescimento, atualmente possui cerca de 15.000 habitantes e, devido ao crescimento rápido e desordenado, é marcado por sérios problemas de infraestrutura, não possuindo rede de esgoto, praticamente em todas as ruas o esgoto corre ao ar livre, as ruas pavimentadas são somente as principais em que o transporte público circula, além de ter sérios problemas de acesso à região central do município. A população do bairro é predominantemente oriunda da zona rural do estado que migraram para a região em busca de oportunidades nas fábricas e galpões que compõem o polo industrial do município e pelo Centro Estadual de Abastecimento (CEASA), que fica próximo ao bairro.

Para compreendermos o contexto social da escola pesquisada e os aspectos emocionais e de aprendizagem das crianças em processo de alfabetização, em tempos de pandemia, podemos citar Gôngora e Souza, que descrevem que a compreensão do pensamento humano para Vigotsky: 
Somente é possível quando se considera sua base afetivo-volitiva, uma vez que as dimensões do afeto e da cognição estão desde cedo relacionadas íntima e dialeticamente. Sendo assim, as emoções do sujeito estão conectadas aos processos psicológicos e ao desenvolvimento da consciência de um modo geral. (SOUZA, 2013, p.01)

Deste modo compreendemos que a instituição escolar contribui para que a criança desenvolva seu potencial e amplie seu conhecimento de mundo. Portanto, o ingresso da criança no ensino fundamental I é de extrema importância, pois é nessa fase que ela é apresentada ao mundo letrado e a função social da leitura e da escrita. Tais aprendizados ampliam as vivências de aprendizado escolar, no âmbito familiar e social. O aprender a ler e a escrever é complexo, pois não depende apenas da idade, mas também do seu desenvolvimento.

Os fatores fundamentais para a aprendizagem são o emocional, o intelectual, o psicomotor, o físico e o social. Além de ser uma atividade que gera significativa expectativa por parte do núcleo familiar da criança. O emocional é o mais importante de todos e dele depende todo o processo educativo. Desse modo compreendemos que o processo da aprendizagem e as emoções são fatores importantes no processo de aquisição do conhecimento e na construção da subjetividade da criança. (SOUZA, 1972, p.26)

\section{Aspectos emocionais e cognitivos x Ensino remoto no processo de alfabetização}

$\mathrm{Na}$ escola é comum as famílias exporem queixas das crianças, sobre questões de aprendizagem, como relatos de baixo rendimento, dificuldade de aprendiza- 
gem em uma ou mais matérias, como também inquietação em sala de aula que impossibilitam a concentração. Conforme a professora entrevistada, atualmente, são questões que chegam na escola com frequência, sendo necessário realizar a avaliação da criança, buscando se há existência de alguma questão que não seja fisiológica e esteja contribuindo para essa situação trazida pela família, pois diversos fatores contribuem para apresentação desse quadro, como questões sociais, familiares e como ela percebe o mundo e suas relações.

A fase inicial da escolarização, ou seja, primeiro e segundo ano do ensino fundamental um, é a fase onde a criança tem o prazer de aprender a ler, porém, algumas pressões externas, como família, escola e sociedade, podem desencadear algumas resistências no aprendizado.

Sendo assim, podemos afirmar que "A aprendizagem de leitura é, em geral, a primeira tarefa educativa geradora de tensão ou ansiedade com o qual a criança se defronta". (MUTSCHELE, 1988, p. 79)

Conforme a profissional entrevistada a pandemia trouxe interferência na aprendizagem de forma direta e indireta, pois as aulas remotas e o isolamento físico/ social interferiram na relação da criança com o mundo, o que contribuiu com dificuldades no rendimento escolar. O papel do professor é trabalhar na identificação e intervenção de situações onde a condição da dificuldade de aprendizagem promove algum tipo de problema que tenha efeitos no desenvolvimento cognitivo e emocional.

Embasado na fala da professora podemos identificar que, "Devido ao desejo primário de ser aceito, de participar da vida do grupo, como seu componente, a experi- 
ência mais penosa para qualquer criança é o sentimento de ser inferior aos outros". (DREIKUSRS, 1971, p. 21)

A entrevistada relata que o contato com a família, nesse momento serve para entender melhor a realidade familiar e social da criança e entender quais intervenções são possíveis. A professora, precisou deixar claro a diferença entre as aulas presenciais e remotas e delimitar o limite das suas ações, para que a partir dessa diferença a família passasse a ter consciência que a dificuldade da criança pode ser por vários fatores. A professora destaca que as aulas remotas dificultaram a experiência das crianças em relação às coisas concretas.

Dessa forma foi essencial proporcionar momentos onde as crianças puderam expressar suas emoções e sentimentos e compreender como as crianças funcionam nas relações, como elas se sentem, como se relacionam e para o que se retrai. Esse trabalho foi realizado de forma lúdica e sensível em parceria com a professora do laboratório de informática, através de atividades, vídeos, músicas e estabeleceu uma ponte de comunicação entre a criança e as professoras, passando a ser um instrumento, onde a criança passa a falar sobre si e como ela lida com situações concretas.

$\mathrm{Na}$ interação mediada pelas atividades, as crianças forneceram elementos e enquanto a criança vai reconhecendo quem ela é, e como lida com as situações, a criança passa a ter a alternativa de mudanças comportamentais e de reconhecimento do que ela está sentindo diante de determinadas situações. Autores de várias orientações ressaltam sobre o valor funcional e experiencial de experiências lúdicas:

Conversar com a criança; dispor de materiais para conversar; compreender as dificuldades de 
uma criança a partir da sua expressão por meio de brinquedos são exemplos de atitudes que pressupõem um diálogo entre um adulto - no caso clínico, o terapeuta - e uma criança, quando ela, mediada pelos brinquedos, tenta dizer quais são suas preocupações, suas dificuldades, se concorda ou não em estar ali naquele contexto ludodiagnóstico. Enfim, trata-se de um "diálogo" em que pressupomos um tipo de linguagem. (AFFONSO, 2012, p.38)

Por vezes esse papel da escola como o espaço de uma possível investigação de um problema de aprendizagem, é citado como um fator de dificuldade pela professora. Pois, a escola surge como um ambiente de investigação das potencialidades e dificuldades de cada estudante. $\mathrm{E}$ muitas vezes um aluno sinaliza que tem algo de que precisa ser cuidado, ainda mais nessa faixa etária, de seis e sete anos, pois, existem situações e possíveis diagnósticos que só ocorrem nesse período, por conta do momento que eles estão vivenciando no processo de aprendizagem em relação à leitura e à escrita. Mas essa situação é ainda mais complicada, pois o sistema municipal, a qual a escola está inserida não oferece uma equipe multiprofissional na identificação e solução de acasos mais específicos. Sobre a importância da contribuição da psicologia na escola e do trabalho conjunto entre psicólogos e professor Martinez discorre:

A orientação aos professores, assim como a contribuição para sua formação no que diz respeito à complexidade, à especificidade e à singularidade dos processos subjetivos implicados na aprendizagem e no desenvolvimento nas suas mais variadas formas de expressão, torna-se uma importante contribuição do psicólogo na instituição escolar. (MARTINEZ, 2010, p.46) 


\section{Análise dos resultados}

A demanda por uma equipe multidisciplinar que apoiasse o trabalho pedagógico na escola sempre existiu, mas com a pandemia, os desafios se acentuaram e o contato diário de outros profissionais com educadores, iriam possibilitar o embasamento necessário para intervir com ações específicas diretamente com a criança, com a escola e se necessário com a família.

No tocante ao entrelaçamento da dificuldade de aprendizagem e as emoções, a professora explica que a criança tem uma interação e uma ligação com o mundo e esse mundo envolve a família e a escola, envolve os coleguinhas e o mundo físico, de acordo com o que vai crescendo, essas experiências aumentam em relação a todos esses elementos e nessa ampliação a criança passa a vivenciar coisas que ao olhar do adulto, pode estar tudo bem ou pode ter alguma problemática e entre essas várias coisas o aprendizado pode ser um fator.

Dessa forma é necessário entender uma dificuldade de aprendizagem ou uma queda de rendimento escolar como uma comunicação, não é apenas a nota ou a dificuldade de leitura, isso é apenas o concreto. Atendimento clínico não é só olhar para criança, ou só para família, ou só para escola, ou só social, é tentar fazer um entrelaçamento desses elementos todos, somados com a relação com o terapeuta.

A família e a escola são provavelmente as instituições sociais mais importantes durante os anos de formação da criança. Cabe a elas transformar uma criança dependente e imatura em um membro responsável, autossuficiente e em condições de contribuir para o bem-estar de sua comunidade. (ALENCAR, 1982, p.135) 
A entrevistada reconhece haver muitas vezes uma pressão da escola para a criança aprender a ler naquela determinada idade, ou seja, existe um padrão e a escola vai tentando adequá-la. Ela explica que essa atitude é um sintoma do sistema educacional, onde as políticas públicas e de recursos financeiros estão ligadas aos resultados de avaliações externas de larga escala. Muitas vezes quando a criança não atende ao esperado, é entendido pela escola que tem algo errado e precisa ser solucionado. Outra questão a ser observada é a pressão da família, onde algumas professoras possuem o entendimento de que a criança tem o tempo dela, e a família acredita que a criança precisa aprender a ler antes dos seis anos. O que ocorre é que "Muitas vezes, o processo de aprendizagem é complicado por pressões externas (família, professores), que desencadeiam conflitos intrapsíquicos da criança”. (DUARTE, 1989, p.155)

Mesmo diante de todos os desafios advindos da pandemia e do ensino remoto, a professora assegura que houve um ganho que favoreceu o aprendizado das crianças nesse período: a família. As famílias nunca estiveram tão perto da escola e tornou-se a principal parceira do processo de ensino e aprendizagem. As famílias contribuíram para o aprendizado das crianças, para além dos aspectos cognitivos, foram essenciais no fortalecimento de aspectos emocionais. Foi necessário conscientizá-los que há uma pressão sob a criança e que caso não haja esse entendimento, é possível dificultar ainda mais a aprendizagem. Mas temos que destacar que houve relatos de negligência no acompanhamento de muitas famílias influenciado por diversos fatores sociais e econômicos. 


\section{Considerações finais}

No decorrer deste artigo foi possível constatar que as questões de cunho afetivo/emocional são de suma importância no que se a refere aluno/escola/família. A transmissão de conteúdo, o pensamento lógico, a afetividade e a sensibilidade humana devem receber a mesma importância que as outras áreas, o ato de educar é um conjunto do todo.

É importante ressaltar que as abordagens devem ser elaboradas com frases curtas, retomando o percurso feito e respondendo aos objetivos. Não devem ser apresentadas informações novas ou citações.

\section{Referências}

SAWALA, Bader Burihan. "Psicologia e desigualdade social: uma reflexão sobre liberdade e transformação social” 2010.

GÔNGORA, Karinna Pereira e SOUZA, Vera Lucia Trevisan de. "Afetividade em Vigostski: um estudo do conceito em pesquisas desenvolvidas sob o enfoque da psicologia histórico-cultural" Anais do XVIII Encontro de Iniciação Científica - ISSN 1982-0178. Anais do III Encontro de Iniciação em Desenvolvimento Tecnológico e Inovação - ISSN 2237-0420, 24 e 25 de setembro de 2013. 
LIMITES E POSSIBILIDADES DO ENSINO REMOTO NA EDUCAÇÃO DE JOVENS E ADULTOS (EJA DA EMEIEF JOSÉ ASSIS DE OLIVEIRA NO MUNICÍPIO DE MARACANAÚ - CE)

\author{
Beatriz Dias Sousa? \\ Edinir Silva Teixeira² \\ Márcio Roque Cordeiro ${ }^{3}$ \\ Maria Eliene Magalhães da Silva ${ }^{4}$
}

\title{
Considerações iniciais
}

A docência é uma atividade complexa que demanda de quem a exerce o domínio de conhecimentos de ordens distintas que permitem não só oportunizar aos educandos o acesso ao conhecimento historicamente

1 Graduada em Pedagogia; Especialista em Didática - UECE; Especialista em Coordenação Pedagógica - UFC; Especialista em Educação Especial e Inclusiva e Neuropsicopedagogia Institucional e Clínica - FAVENI; Gestora escolar do município de Maracanaú/ CE; E-mail: biadiassousa@gmail.com

2 Licenciada Plena em PEDAGOGIA e em Matemática pela UVA. Especialista em Gestão Escolar: UVA. Professora Efetiva da Rede Municipal de Ensino de Maracanaú desde 2008. Gestora Escolar da Rede Estadual de 2013 a 2017. Gestora Escolar da Rede Municipal no Ano de 2012 e hoje na EMEIEF José Assis de Oliveira desde 01.08.2017. E-mail : professoraedinirteixeira@gmail.com

3 Graduado em Pedagogia - UFC; Habilitação em Matemática e Física - UVA; Psicólogo - UNIFOR; Especialista em gestão e avaliação da Educação Básica - UFJF; Professor do município de Maracanaú/CE; Professor da Rede Estadual do Ceará; E-mail: marciorqcordeiro@gmail.com

4 Graduada em Ciências da Religião - ICRE; Graduada em Pedagogia - UVA; Graduada em História UVA; Graduada em Letras/Português - UFC; Especialização em psicopedagogia - UFC; Especialização em Ensino religioso - FINOM; Especialização em História para Formação de Professores de Quilombos - UFC; Mestra em Educação - UFC; Professora de Caucaia e São Gonçalo do Amarante; E-mail: elienemariajacyra@gmail.com 
construído pela humanidade, mas utilizá-lo a favor de uma melhor compreensão da realidade e de inserção nos diferentes espaços de socialização, na cultura, no trabalho, na política, entre outros. Essa compreensão, apesar de não soar estranha aos ouvidos de todos os educadores, se constitui sempre como um desafio, sobretudo pela experiência formativa vivida no contexto brasileiro, marcada, de forma importante, por práticas de reprodução do conhecimento, conforme tanto criticou Paulo Freire (1991).

No contexto educacional do ano de 2020, fomos acometidos pela Pandemia mundial de um novo Coronavírus, que nos conduziu à necessidade de realizar o distanciamento social para prevenção, tendo em vista o alto nível de contágio do vírus e a inexistência de uma medicação com eficácia cientificamente comprovada ou vacina contra o mesmo.

Diante dessa realidade, as aulas em todos os municípios do Ceará foram suspensas, para evitar a rápida propagação do vírus. O mesmo ocorreu com as aulas da Educação de Jovens e Adultos no município de Maracanaú.

No primeiro momento, pensamos que o distanciamento seria breve e logo voltaremos às nossas atividades e rotinas diárias, consequentemente às aulas presenciais, mas infelizmente não foi assim que se sucedeu.

O governador do Estado do Ceará, através do Decreto n.o 33.510, de 16 de março de 2020, determinou a suspensão das aulas em todas as instituições de ensino, inicialmente por um período de 15 dias, mas necessitando ser prorrogado recorrentemente baseado com base nas recomendações da Organização Mundial da 
Saúde (OMS), que indicou o isolamento social como a forma segura de prevenção da doença.

Diante deste cenário, o município de Maracanaú, com a Secretaria de Educação, em comum acordo com o sindicato de professores, antecipou as férias escolares para o mês de abril do corrente ano. Por esse motivo o ensino remoto teve início apenas em maio de 2020, estabelecendo-se essa metodologia de ensino durante a Pandemia da COVID-19.

Frente a essa realidade e considerando o processo de busca de estratégias, construção de recursos e aprendizagem de novas formas de aproximação com os estudantes, o presente texto objetiva relatar a experiência dos professores no ensino remoto da Educação de Jovens Adultos (EJA), numa escola municipal de Maracanaú, no caso a EMEIEF José Assis de Oliveira no período da Pandemia mundial do novo Coronavírus. E ainda, solucionar o problema central deste estudo: quais os limites e as possibilidades do ensino remoto para os alunos do segmento EJA?

$\mathrm{Na}$ tentativa de solucionar o problema proposto, optamos por utilizar a abordagem qualitativa, pois entendemos que escolher os caminhos para um trabalho é muito importante, é o norteador de todo um processo. Assim, optamos por uma pesquisa bibliográfica, caracterizada como uma abordagem que explora fenômenos qualitativos, onde a fundamentação teórica qualifica os levantamentos. (LUDKE; ANDRÉ, 2010).

A área educacional vem se constituindo num campo muito rico para o avanço da investigação qualitativa. Há algum tempo, a pesquisa em educação tem se preocupado em captar a dinâmica do fenômeno educacional e a realidade complexa do dia a dia das escolas. 
Os resultados, discutidos considerando Cortella (2014), Freire (1995) e Gadotti (2014), dentre outros aqui citados, apontam que a simples transposição das práticas presenciais para o modelo remoto reforça os limites já encontrados pelos discentes na assimilação dos conteúdos, potencializando os processos de exclusão, ao passo que a construção das aulas com base nas pistas fornecidas pelos estudantes acerca dos limites e possibilidades das estratégias de ensino utilizadas se aproxima das reais condições de aprendizagem dos mesmos e favorece processos de inclusão.

O relato revela-se de grande importância para os professores e profissionais da educação, em virtude da experiência expor a reflexão sobre a prática docente diante do momento atípico pelo qual estamos passando, pois, o mesmo reflete sobre o ensino remoto na modalidade EJA, destacando os limites e possibilidades dessa metodologia e seus impactos na aprendizagem significativa dos discentes.

\section{O Lócus do relato}

O referido relato apresenta reflexões sobre nossas práticas docentes na turma do Ciclo Inicial 1, da Educação de Jovens e Adultos da EMEIEF José Assis de Oliveira, uma escola pública do município de Maracanaú, no Estado do Ceará.

Somos Gestores na referida escola onde possuímos três turmas da EJA, no turno noturno, e escolhemos observar a turma de Ciclo Inicial I, onde temos duas professoras lotadas, uma desempenhando a função de Professor Regente 1(P1), responsável pelos componentes curriculares de Língua Portuguesa, História, 
Geografia, Artes, Ensino Religioso e Educação Física. E a segunda Professora (P2) tem a responsabilidade pela turma compartilhada com o Professor Regente 1 (P1), sendo que a P2 ministra Matemática e Ciências, nos dias de planejamento, visto que o município disponibiliza um terço da carga horária para o planejamento pedagógico conforme a Lei de Diretrizes e Bases da Educação Nacional LDB n.o 9394/1996. (BRASIL, 1996).

Os planejamentos são acompanhados pela coordenação pedagógica da escola e por uma equipe técnica da Secretaria de Educação do município, com a qual a gestão e professores se reúnem mensalmente para realizar estudos e trocas de saberes e experiências com outras escolas e com outros educadores da EJA. Por ocasião da Pandemia, reuniões e planejamentos estão ocorrendo de maneira remota.

A turma de Ciclo Inicial 1 corresponde ao primeiro segmento da educação básica, onde os alunos estão no processo de alfabetização e letramento, visto que a maioria nunca frequentou a escola anteriormente. A sala é composta por 25 (vinte e cinco) alunos, sendo a maioria adultos, 18 estudantes com idades entre 30 (trinta) e 60 (sessenta) anos, e os demais alunos com idade entre 17 e 29 anos. Os níveis de alfabetização são heterogêneos, porque temos alunos do nível pré-silábico até o nível alfabético.

Salientamos o quanto foi desafiador alfabetizar um grupo de alunos de modo remoto sem o diálogo e a interação que são componentes indispensáveis para o desenvolvimento de uma aprendizagem significativa e emancipadora como defende Freire:

Não devemos chamar o povo à escola para receber instruções, postulados, receitas, ameaças, 
repreensões e punições, mas para participar coletivamente da construção de um saber, que vai além do saber de pura experiência, feito que leve em conta as suas necessidades e o torne instrumento de luta, possibilitando-lhe transformar-se em sujeito de sua própria história (FREIRE,1991, p.16).

Assim concebemos a escola como um espaço de diálogo, de troca de experiências e de construção de conhecimentos capaz de transformar a sociedade. Frequentar a escola, portanto, precisa ter um significado. Os jovens e adultos que abandonam a escola, quando retornam, precisam reconhecer sua importância, se identificar com ela de alguma forma.

Não é possível a educadoras e educadores pensar apenas os procedimentos didáticos e os conteúdos a serem ensinados aos grupos populares. Os próprios conteúdos a serem ensinados não podem ser totalmente estranhos àquela cotidianidade. $\mathrm{O}$ que acontece, no meio popular, nas periferias das cidades, nos campos - trabalhadores urbanos e rurais reunindo-se para rezar ou para discutir seus direitos - nada pode escapar à curiosidade arguta dos educadores envolvidos na prática da Educação Popular. (FREIRE, 1995, p.13).

Educadores que ensinam o conteúdo sem relacioná-lo à vida, tendem a estimular o desinteresse do aluno pela escola e esse desinteresse resulta normalmente na evasão escolar, que, finalmente, atinge o aluno em potencial da EJA. Se esse educando já passou por um fracasso escolar e, por um motivo ou outro, resolver tentar mais uma vez retornar à escola, o mínimo que o professor pode fazer é tornar esse retorno agradável. $\mathrm{O}$ aluno precisa ver que a escola pertence ao seu mundo e não é um universo à parte. 
Nesse sentido, o papel do professor se mostra imprescindível à prática escolar. Não podemos conceber a escola, em especial as turmas de EJA, sem a presença dos docentes. Nesses últimos meses evidenciamos uma verdadeira ressignificação da prática diária de educadores pelo país à medida que buscam novas formas de chegar aos estudantes por conta do isolamento social. $O$ que não diferiu na EJA da EMEIEF José Assis de Oliveira, escola da qual estamos falando.

\section{Tecendo considerações sobre a Educação de Jovens e Adultos}

A educação voltada para jovens e adultos está presente nas mais variadas regiões no estado do Ceará com uma abundante de escolas e atividades prestadas para os estudantes. Encontramos nos centros específicos para esse segmento de ensino e nas escolas que englobam a mesma metodologia de ensino regular que geralmente apresentam o nível fundamental e médio regular durante o período diurno e noturno para o ensino de Jovens e Adultos.

Considerando que na Educação de Jovens e Adultos, é fundamental compreender a especificidade do seu público em relação à diversidade etária, sociocultural, geográfica, cognitiva, de gênero, dentre outras, e traduzir esta especificidade na garantia do acesso e da qualidade sócio educacional necessária à sua emancipação. Pensando nisso a Secretaria de Educação do Estado do Ceará (SEDUC-CE), através das políticas públicas educacionais direcionadas a Educação de Jovens e Adultos assegura a oferta de educação escolar para jovens e adultos, com características adequadas às suas 
necessidades e disponibilidades garantindo aos que forem trabalhadores as condições de acesso e permanência na escola (GADOTTI, 2014).

\section{A experiência do ensino remoto}

As aulas remotas no município de Maracanaú iniciaram em maio de 2020 após o retorno das férias dos professores. Dessa forma, fomos amparados pelo decreto municipal que ampara essa metodologia de ensino para amenizar os impactos do isolamento social no processo de ensino e aprendizagem dos alunos da rede pública de ensino.

Antes do início das aulas, realizamos uma reunião virtual através do aplicativo Google Meet para nos orientar sobre como proceder diante desse novo desafio. Nessa reunião ouvimos e sugerimos que criássemos um grupo no aplicativo de mensagens com alunos, professores e coordenadores para nos comunicarmos, disponibilizar materiais para as aulas, respeitando os respectivos horários, de cada professor e para a devolutiva das atividades propostas aos alunos.

Assim, iniciamos as nossas aulas de forma remota, criamos o grupo e nos surpreendemos com a adesão e participação dos alunos, visto que apenas uma aluna não aderiu ao grupo, por não possuir um aparelho de celular. Estrategicamente, disponibilizamos materiais impressos semanalmente na escola, para que todos os alunos tivessem acesso às atividades propostas.

Então, passamos a utilizar o grupo para as aulas, e percebemos o quanto essa metodologia exigia cuidado nos planejamentos, pois estes precisavam ser mais minuciosos de modo que superaremos o agravante da fal- 
ta do contato direto com os alunos, que dificulta a troca de saberes mediados pelo diálogo, tão necessário nessa modalidade de ensino, sobretudo no processo de alfabetização de alunos da EJA como afirma Freire:

O diálogo é o encontro entre os homens, mediatizados pelo mundo, para designá-lo. Se ao dizer suas palavras, ao chamar ao mundo, os homens o transformam, o diálogo impõe-se como o caminho pelo qual os homens encontram seu significado enquanto homens; o diálogo é, pois, uma necessidade existencial (FREIRE, 1980, p.42)

Dessa forma, como estávamos privados dos encontros presenciais e dos diálogos fundamentais para a troca de saberes, buscamos aporte teórico didático para fomentar as aulas, mediar o processo de ensino aprendizagem nesse novo formato, de modo que nossos alunos conseguissem compreender e desenvolver a sua autonomia na aprendizagem, sendo necessário todos nos apropriar das novas Tecnologias Digitais da Informação e Comunicação (TDIC's).

Discorrer sobre o desafio do educador frente ao uso das novas tecnologias pode parecer desnecessário pelo fato de vivermos na sociedade da informação. Assim chamada por tornar através dos meios tecnológicos, a informação acessível e democrática, permitindo que o conhecimento seja repassado além da escola.

A escola, enquanto espaço de transmissão do conhecimento, vem tentando garantir a integração com a sociedade da informação. Muitas vezes, condições adversas impedem a realização de tal tarefa. Essas condições têm a ver com a dificuldade que as instituições de ensino encontram para exercer sua autonomia técnica financeira. 
O universo digital oferece incontáveis e diferentes possibilidades de aprendizagem dentro e fora da escola. Sobre esse aspecto, é importante saber como acontece a apropriação dessas possibilidades no interior das escolas pelos seus diversos atores.

Complementando e confirmando a importância de um olhar atento sobre a metodologia usada na escola Cortella (2014, p.26) diz que: "Se a escola não prestar atenção nessa dinâmica, no material didático, na leitura, vamos perder essa condição de interagir e de aproximação". O autor considera a interação e a aproximação elementos essenciais e relevantes para a transição entre as duas categorias de educação.

Porque para Cortella (2014, p.53) "Não é a tecnologia que torna uma mente moderna. Mas uma mente moderna não recusa tecnologia quando ela é necessária - e ela o é em inúmeros momentos e não o é em tantos outros".

E a pergunta oportuna é: a tecnologia é necessária na escola? Frente a realidade vivenciada por nós antes após pandemia, percebemos que sim. A escola como uma extensão da família e da sociedade, além de outras funções, precisa estar conectada e aberta às diversas situações de aprendizagem, desde que não se deixe perder pelo fascínio que a tecnologia provoca e esqueça da sua principal função: transmissora e construtora do conhecimento. Esse alerta também é dado por Cortella que ressalta:

Cautela! A área de Educação Escolar ainda não pode ser privada da capacidade de comunicação direta, de trabalho docente, da formação e, especialmente, do uso da mais avançada das tecnologias humanas, um dispositivo chamado cérebro. Ele é wireless, bluetooth, é reformatável, além 
de ser movido a carboidrato, proteína e açúcar (CORTELLA, 2014 p.54).

Na verdade, o autor chama a atenção para a necessidade de sedimentação das informações para garantir que o conhecimento, as relações e a pesquisa nessa sociedade apressada não fiquem apenas na superficialidade.

É necessário destacar que, falta aos professores a capacidade/qualificação técnica e conhecimento sobre quais contribuições as TDIC's podem oferecer nas diversas situações de aprendizagem. Para Perrenoud:

As novas tecnologias podem reforçar a contribuição dos trabalhos pedagógicos e didáticos contemporâneos, pois permitem que sejam criadas situações de aprendizagens ricas, complexas, diversificadas, por meio de uma divisão de trabalho que não faz com que todo o investimento repouse sobre o professor, uma vez que tanto a informação quanto a dimensão interativa são assumidas pelos produtores dos instrumentos (PERRENOUD, 2000, p. 139).

Entendemos que de posse dessas ferramentas tecnológicas é possível aliviar o fardo que recai sobre o professor de solitário detentor e distribuidor do "saber" passando a existir um processo colaborativo de ensino.

\section{Desafios e possibilidades}

Apesar dos esforços para tornar as aulas mais atraentes e motivadoras, percebemos que a participação dos alunos se reduziu significativamente com o passar das semanas. Muitos alegaram não poder acessar a Internet, necessária para visualizar as aulas, visto que as mesmas eram disponibilizadas pelo aplicativo que necessita de internet. 
Diante dessa complexa realidade, decidimos junto à gestão da escola disponibilizar atividades impressas como o conteúdo semanal, repassadas para o correio eletrônico da escola, que se responsabiliza pela impressão e entrega aos alunos, que vão uma vez por semana na escola buscá-las para realizá-las em casa. No entanto, essa didática tem suas limitações visto que o aluno não tem acesso às aulas explicativas, disponibilizadas no grupo de aplicativo através de vídeos e áudios. Outra limitação é o acompanhamento da aprendizagem dos alunos, porque não temos as devolutivas das atividades realizadas.

Percebemos que as aulas precisavam ser mais atrativas, claras e objetivas, visto que alunos e professores não tinham a troca de experiências através do diálogo direto, que tanto enriquece as aulas presenciais contribuindo para o desenvolvimento da aprendizagem dos alunos da EJA.

Com o intuito de superar esses desafios, decidimos produzir vídeos e gravar áudios para nos sentirmos mais próximos dos alunos, viabilizando o sentimento de acolhimento destes também aproximando professores e alunos mesmo que remotamente. Para fomentar as aulas buscamos, também, vídeos nas mídias sociais sobre as temáticas das aulas, vislumbrando tornar as aulas mais atrativas e motivadoras. No entanto, ressaltamos as dificuldades de encontrarmos material próprio para o público da EJA, seja em vídeos ou atividades. Foi necessário cuidado para não infantilizar o ensino nessa modalidade, disponibilizar atividades ou vídeos de determinados assuntos com a linguagem inadequada para essa faixa etária, arriscando ter o efeito contrário, ou seja, no lugar de motivar causar a desmotivação. 
Outro desafio do ensino remoto que podemos destacar, é a limitação por parte dos professores da utilização das TICS e das mídias sociais como recurso para dinamizar as aulas, visto que existe uma certa resistência por parte destes em aprender o novo.

A existência desses meios configura um avanço em termos estruturais, mas é preciso reformular as políticas educacionais e a 'práxis' pedagógica na perspectiva de uma educação transformadora. Segundo Almeida e Prado (2005), a tecnologia nas escolas deve ser pautada em princípios que privilegiam a construção do conhecimento, o aprendizado significativo, interdisciplinar e humanista. Daí a necessidade dos professores se apropriarem das novas tecnologias e desenvolverem estratégias para um ensino-aprendizagem eficaz, não perdendo de vista o educando e o seu contexto social.

Segundo Allan (2015) o problema não é a tecnologia e sim a visão de ensino arcaica, que desconsidera as transformações da sociedade. E acrescenta:

A tecnologia digital, que estimula o compartilha-
mento do saber, representa um grande desafio
para uma geração de professores que estudou e
aprendeu a ensinar em uma era pré digital, sem
recursos de interação e colaboração capazes de
conectar mestres, estudantes e a sociedade civil
de uma forma geral, independentemente de for-
mação, cultura ou nação onde vivem. (ALLAN,
2015, p. 40)

Esse distanciamento entre a formação do professor e as exigências da era digital apresenta-se como uma das principais dificuldades na aplicação pedagógica das tecnologias da informação no dia a dia da sala de aula. Por essa razão, é preciso repensar a prática de ensino e adquirir novas competências para acompanhar as mudanças. 
Percebemos que diante do desafio de planejar e realizar aulas remotas muitos buscaram superar essa limitação buscando conhecimentos nessa área através de cursos ou na aprendizagem autônoma mesmo, pois cabe ao professor utilizar artifícios de modo a desenvolver amplamente as habilidades, enfatizando a competência adequada a cada situação.

Temos ciência dos desafios do ensino remoto da EJA, imensuráveis, mas temos a consciência de que podemos buscar soluções viáveis para superá-los e não permitir que os alunos se desmotivem e desistam, pois, sabemos das dificuldades enfrentadas para que estes voltassem a estudar nessa fase da vida. Dessa forma, necessitamos estar sempre em contato com os discentes, mesmo que remotamente, para que eles se sintam acolhidos nesse momento tão atípico que estamos passando.

\section{Considerações finais}

Diante o estudo podemos constatar que a EJA é uma modalidade de ensino que está, de fato, contemplando muitas pessoas que acreditavam ser impossível retomar os estudos pelas vias tradicionais. É uma oportunidade, já utilizada no Estado do Ceará, de aprimorar os conhecimentos dos alunos que, por diversas razões, abandonaram a escola.

Percebemos de forma muito acentuada, inúmeros desafios do ensino remoto na educação jovens e adultos no município de Maracanaú. Como a falta de aparelho celular ou de internet para acessar as aulas remotas, a falta de material de apoio para os professores que atuam nessa modalidade de ensino, assim como o despre- 
paro dos mesmos na utilização das TDIC's e das mídias sociais. Destacamos também a dificuldade na devolutiva das atividades dos alunos inviabilizando o acompanhamento do processo de ensino - aprendizagem dos alunos. Ressaltamos, contudo, as aprendizagens adquiridas diante desse novo cenário. A necessidade de desenvolver novas habilidades nos fizeram buscar formas diferentes de mediar a aprendizagem através das TICs e das mídias sociais. Diante desse novo cenário, tivemos a oportunidade de refletir sobre a nossa prática, nos levando a repensar nossas metodologias de ensino. Repensamos e mudamos, mesmo que involuntariamente, para viabilizar a aprendizagem significativa dos nossos alunos.

É importante salientar que os alunos buscam a escolarização tentando responder às exigências impostas pelo mundo letrado. Eles acreditam que ao dominar as habilidades de ler e escrever poderão conquistar a independência, facilitando as necessidades ligadas à sobrevivência. Apesar da demora na aquisição dessas habilidades, por conta da falta de oportunidade, eles encontram meios para interagir com a realidade, demonstrando competência comunicativa.

Salientamos, por fim, que ainda estamos em processo, mas estamos convictos de nossa capacidade de nos renovar e reinventar diante das adversidades. É o que estamos fazendo nesse momento histórico para a educação brasileira.

\section{Referências}

ALMEIDA, Maria Elizabeth Bianconcini; PRADO, Maria Elisabette Brisola Brito. Apresentação da Série integração de tecnologias com as mídias digitais. In: Boletim do Salto para o Futuro. Brasília: MEC, SEED, 2005. 
ALLAN, Luciana. Escola.com. Barueri, SP: Figurati, 2015. BRASIL. Ministério da Educação. Lei 9.394, de 20 de dezembro de 1996. Estabelece as diretrizes e bases da educação nacional. Diário Oficial da República.1996.

CORTELLA, Mario Sergio. Educação, Escola e docência: Novos tempos, novas atitudes. São Paulo: Editora Cortez, 2014.

FREIRE, Paulo. Pedagogia do Oprimido. 10. ed. Rio de Janeiro: Paz e Terra, 1995.

. A Educação na Cidade. São Paulo: Cortez; 1991.

. Conscientização: teoria e prática da libertação.

3. ed. São Paulo: Cortez \& Moraes, 1980.

GADOTTI, Moacir. Por uma política nacional de educação popular de jovens e adultos. São Paulo: Moderna: Fundação Santillana, 2014.

LUDKE, Menga; ANDRE, Marli E.D.A. Pesquisa em Educação: abordagem qualitativa. 8. ed. São Paulo: EPU, 2010.

PERRENOUND, Philippe. Dez novas competências para ensinar. Porto Alegre: Artemed, 2000. 


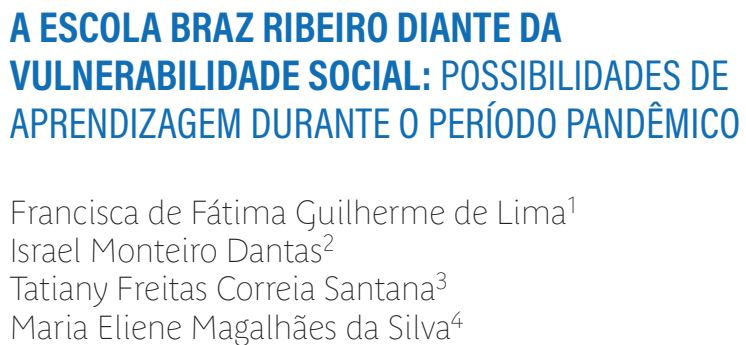

\section{Introdução}

Assim como ocorrera em outros municípios, as escolas municipais de Maracanaú sofreram diante da pandemia da Covid-19, onde as atividades escolares passaram a serem ministradas, via internet, pelo chamado "estudo remoto", consequentemente as atividades domiciliares, exercícios e provas passaram a ser encaradas de forma inesperada para muita gente, seja no ambiente escolar ou familiar. Os pais tiveram de se adaptar a um novo estilo de vida, ao lado dos filhos, por conta da integração imposta pelo sistema on-line nessa

1 Especialista em Gestão Escolar/ISTA, Graduada em Pedagogia/ UVA. Professora efetiva da Educação Básica do Município de Maracanaú/CE. E-mail: fatimaguilherme06@gmail.com

2 Especialista em Administração Escolar/UVA, Especialista em metodologia do ensino fundamental e médio/UVA, Licenciado em pedagogia/UVA. Professor efetivo da Educação Básica do Município de Maracanaú/CE. E-mail: israelmd7@gmail.com

3 Especialista em Gestão Educacional/FAERPI. Licenciada em Biologia/UECE. Professora efetiva da Educação Básica do Município de Maracanaú/CE. E-mail: tatianycorreia@gmail.com

4 Graduada em Ciências da Religião - ICRE; Graduada em Pedagogia - UVA; Graduada em História UVA; Graduada em Letras/Português - UFC; Especialização em psicopedagogia - UFC; Especialização em Ensino religioso - FINOM; Especialização em História para Formação de Professores de Quilombos - UFC; Mestra em Educação - UFC; Professora de Caucaia e São Gonçalo do Amarante; E-mail: elienemariajacyra@gmail.com 
nova modalidade de estudo. Se já era difícil um acompanhamento por parte da família, antes da pandemia, imaginem agora com toda dificuldade econômica e social, e tendo que, ao mesmo tempo, buscarem o alimento para o lar.

A reflexão proposta neste artigo é analisar e buscar os meios necessários para o enfrentamento dos novos desafios educacionais, usando uma metodologia que atendesse tanto de forma on-line (grupo em redes sociais) como de entrega na escola das atividades impressas e, atendendo os casos omissos, entrega em domicílio, visto que a pandemia nos mostrou a importância de sermos responsáveis por nós e pelo próximo. Devemos carregar consigo esta premissa para o novo normal que se avizinha. O futuro ainda incerto traz consigo uma nova nomenclatura que, por enquanto, denomina-se de novo normal.

Uma frase que traduz bem a situação porque passam pessoas e paises nesse período de pandemia é a célebre frase de Albert Einstein:

"Não pretendemos que as coisas mudem, se sempre fazemos o mesmo. A crise é a melhor bênção que pode ocorrer com as pessoas e países, porque a crise traz progressos. A criatividade nasce da angústia, como o dia nasce da noite escura. É na crise que nascem as invenções, os descobrimentos e as grandes estratégias. Quem supera a crise, supera a si mesmo sem ficar "superado". (g1.globo.com, acessado em 17/11/2021, às 15h 10min).

\section{A vulnerabilidade social e suas consequências}

A prefeitura do município publicou um decreto que estabeleceu a suspensão das atividades escolares 
presenciais e, de igual modo, o comércio de Maracanaú, só permitindo a abertura àqueles setores considerados essenciais. Consequentemente, quase toda a comunidade estudantil teve de adaptar-se ao que se convencionou de "estudo remoto", onde as aulas passaram a serem ministradas via internet, assim como as atividades domiciliares, exercícios e provas foram acompanhadas pela família, em sua residência.

Há pouco menos de dois anos temos presenciado a dura realidade social porque passa nossa comunidade da Boa Vista - no município de Maracanaú - CE, mui especialmente nossas crianças em fase estudantil, nesse período pandêmico.

A falta de alimento, a dificuldade de emprego, a reclusão de famílias inteiras em seus lares e sem nenhuma condição de assistência hospitalar são algumas das situações presenciadas, visto que os hospitais foram repletos de pessoas contaminadas pelo vírus da covid-19.

Somos sabedores de que a vulnerabilidade social está ligada intimamente à exclusão de cidadãos, consequentemente à falta de representatividade e oportunidades. Pode ocorrer desde as questões pessoais como as de ordem psicológica e emocional, até as de dimensões maiores como de uma comunidade, tais como: saúde, moradia, renda, alimentação, escolaridade e situações de risco. Adicionando a tudo isso as condições de fragilidade, estado de fraqueza e falta de oportunidade. O que pode gerar, em âmbito educacional, até mesmo uma evasão escolar. Segundo Carara:

As crianças e adolescentes que se encontram em situação de vulnerabilidade social são aquelas que vivem negativamente as consequências 
das desigualdades sociais que vão da pobreza e da exclusão social à falta de acesso à educação, trabalho, saúde, lazer, alimentação e cultura (CARARA, 2017, p. 03 ).

Constatamos que a vulnerabilidade social perpassa e interfere diretamente na forma como cada grupo social enfrenta um período pandêmico. As situações de vulnerabilidade não emergem de forma causal devido à chegado do vírus da Covid-19, ao contrário, as vulnerabilidades são estruturais, pré - existentes à pandemia e perpassam por diversos fatores que as intensificam, sendo exacerbados quando aliadas a fatores externos (CARVALHO; SANTOS; SANTOS, 2020, P.3496).

As autoras Carmo e Guizardi (2018), ao conceituarem vulnerabilidade social, demonstra que:

esta não pode ser entendida somente pela perspectiva da desproporção no acesso à renda, muito mais complexo que isso, vulnerabilidade emite as consequências de vínculos familiares rompidos ou fragilizados, acesso ou não acesso a novas possibilidades de se apresentar no mundo, até as formas com que os serviços públicos chegam aos grupos considerados vulneráveis. As autoras fazem críticas às concepções ainda recentes de vulnerabilidade como representadas no âmbito individual ou limitada à grupos específicos, que, por volta do ano de 1980, passou a ser repensada durante a epidemia da Síndrome da Imunodeficiência Adquirida (Aids), em que se pôde observar que fatores sociais, culturais e econômicos estavam relacionados ao grau de infecção de forma mais intensificada do que a concepção individualizante (CARMO E GUIZARD, 2018, P.06). 


\section{A situação da escola municipal Braz Ribeiro durante a pandemia e a sua aplicabilidade do ensino remoto}

A comunidade do entorno escolar tem característica de baixa escolaridade. São famílias que vivem em condições precárias e sem nenhum tipo de renda. Não há, pelo menos de forma perceptível, nenhuma forma de de parcerias público ou privadas que possam auxiliar em nosso país ou amenizar as condições precárias existentes. Mediante a tanta pobreza e para que se tenha pelo menos uma sobrevivência, o poder público na sua obrigatoriedade, sequer manifesta-se para uma solução imediata, e sim, prefere sua omissão a todos os fatos ocorridos, em todo o período pandêmico. Uma comunidade sem representação mínima junto ao poder público.

No período pandêmico ficou evidente o distanciamento entre ricos e pobres, entre brancos e negros, especialmente no processo ensino-aprendizagem no Brasil, salvo algumas situações isoladas em que cidadãos, de forma solidária, socorriam as famílias mais vulneráveis e de extrema pobreza, com doações de alimentos. No município de Maracanaú, um dos problemas estruturais é a falta de acesso a internet para a clientela das escolas municipais, pois muitos têm sofrido com consequências econômicas, políticas, sociais e educacionais. Este cenário trouxe, inevitavelmente, ao centro do debate educacional o uso das tecnologias educacionais para realização de atividades escolares não presenciais. Pois o papel da escola, mediante o contágio mundial, tornou-se muito difícil. Nos deparamos com a necessidade de concentrar esforços na preparação dos professores para o desenvolvimento de situações de aprendizagem remota, que em geral, sendo medidas 
pelo uso eficiente das tecnologias. Consequentemente, foi demandada por parte dos docentes, a capacidade de experimentar, inovar, sistematizar esse conhecimento verificando o processo de aprendizagem de seus alunos, fazendo o melhor uso possível dessas ferramentas, cuja prática, para muitos era então desconhecida.

A clientela da Escola Braz Ribeiro da Silva tem sofrido com esse paradigma e por mais que os professores desenvolvesse um esforço maior, os dados revelam um extremo abismo ainda maior, juntando-se ao período pandêmico e à vulnerabilidade social, a escancada problemática de como auxiliar os nossos estudantes de forma remota e que acaba impondo desafios ainda mais urgentes. Pensamos no melhor: observar todo ciclo de aprendizagem, uso de instrumentos variados de aprimoramento no ensino remoto, promovendo uma aproximação virtual com os estudantes.

Os recursos tecnológicos mais utilizados no ensino remoto pelos professores na escola em estudo, foram as redes sociais. Ainda que, diante da dificuldade enfrentada pelos alunos no acesso à conectividade, a escola disponibilizou atividades impressas a esses estudantes. Apesar da possibilidade da ferramenta digital disponível para o novo formato de ensino, precisamos destacar que esse meio de ensino não favoreceu a todos. Muitos alunos, como já foi mencionado anteriormente, enfrentam às adversidades com a desigualdade social, como a falta de acesso a internet, ou a falta de um computador em sua residência, ou até mesmo a falta de um celular com internet.

Uma das grandes problemáticas identificadas no ensino remoto é que existe uma desigualdade de acesso à internet. 


\section{Dificuldades de aprendizagem no sistema remoto}

Aprendizagem envolve muitas variáveis como, por exemplo: questões biológicas, cognitivas, sociais, entre outras. Mas, muitas vezes o que eles de fato precisam é encontrar uma metodologia que se encaixa com seu perfil. Por outro lado, existem alunos que apresentam dificuldade de aprendizagem seja por não se adaptarem às metodologias aplicadas ou por questões psicológicas. Entende-se que dificuldade de aprendizagem é uma desordem mental que atrapalha o ritmo com que um estudante aprende. Essa desordem pode acontecer por vários motivos, como: metodologia de ensino, ambiente escolar, problemas pessoais e familiares.

As pessoas quando questionadas sobre a possibilidade de haver alguma relação entre vulnerabilidade social e dificuldades de aprendizagem, a resposta é quase que imediata e afirmativa. Isso porque mesmo antes do surgimento da pandemia da covid-19, os estudantes já apresentavam dificuldades de aprendizagem por uma série fatores ligados à família, alimentação, falta de estímulo e sem afetividade. Imagina-se que durante um período pandêmico, as consequências se avolumam em todos os níveis. É violência no lar e fora do lar.

Há uma forte ligação entre o processo de aprender e o bem estar físico, psíquico e social. Há um entendimento diante dessa dificuldade de aprendizagem, pois:

"Dificuldade de aprendizagem significa um distúrbio em um ou mais dos processos psicológicos básicos envolvidos no entendimento ou no uso da linguagem, falada ou escrita, que pode 
se manifestar em uma aptidão imperfeita para ouvir, pensar, falar, ler, escrever, soletrar ou realizar cálculos matemáticos”. Segundo (GRIGORENKO, STERNEMBERG, 2003, P.29)

Figura 1 - Aluna Gabriele em seu estudo remoto, turma Pré II - A

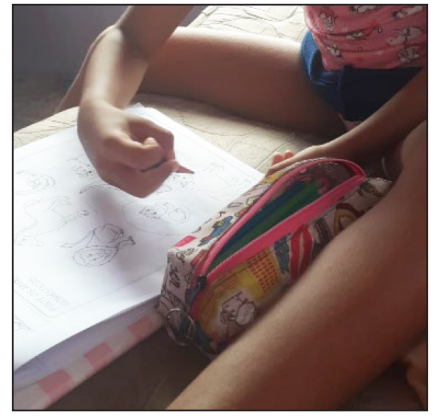

Fonte: Graça, 2021. (vó da Gabriele)

Figura 2 - Aluna Luiza Nathaly, em seu estudo remoto, turma Pré II B

Fonte : Raimunda Santos (avó da Luiza Nathaly).

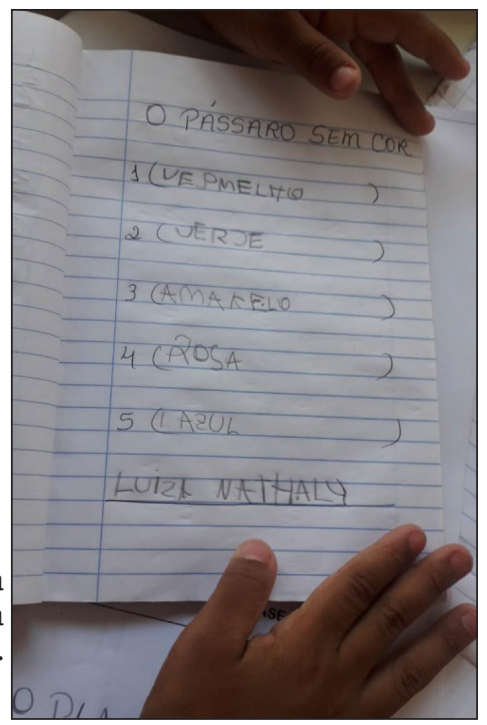




\section{Considerações finais}

A pandemia da COVID-19 obrigou as instituições educacionais e consequentemente os professores, em nível mundial, a alterar drasticamente as suas práticas educativas. Da sala de aula presencial, estudantes no mundo inteiro passaram a ter aulas numa sala de aula virtual, de um momento para o outro, sem um preparo prévio. A adaptação a esta nova realidade não foi um processo fácil , encontramos muitas dificuldades em todos os níveis de ensino, mas foi o possível a fazer diante dos acontecimentos.

Diante de todo um contexto de isolamento social, conclui-se que o resultado desse novo formato de ensino, o ensino remoto, derivou de um acentuado quadro de desigualdade social, mais fragilizada na profissão docente e consequentemente mais desestruturada na educação pública. Haja vista, as limitações dos docentes quanto à sua competência digital e habilidades nas tecnologias e, principalmente, as limitações de um aparato tecnológico e de conectividade dos estudantes das escolas públicas em situações de vulnerabilidade social no qual estão inseridos, conforme o seu perfil socioeconômico.

Por fim, a interação e a qualidade da formação mediadas pelas TIC na EaD estão diretamente vinculadas à competência digital dos envolvidos no processo de ensino-aprendizagem (Oliveira; Coelho; Vieira, 2017), especialmente do professor, sendo condição sine-qua-non para promover uma educação online de qualidade. Essa competência traduz-se, para além da competência técnica em relação ao uso de plataformas e dos recursos digitais, na capacidade de organizar e orientar didatica- 
mente o processo de ensino-aprendizagem à distância, na presença virtual constante e na habilidade para ler e escrever com fluência em ambientes digitais (Vieira; Silva, 2020).

É preciso repensar na concepção de aprendizagem, renovando as nossas práticas de educação, as ações pedagógicas e os próprios sujeitos do processo educacional, os professores, em prol de uma educação transformadora, emancipatória, inclusiva e de qualidade em nosso país. Promovendo impacto na vida de quem vive uma realidade menos favorecida e que sofre com a vulnerabilidade social, tão crescente em nosso país.

\section{Referências}

CARARA, Mariane Lemos. Dificuldade de aprendizagem e vulnerabilidade social sob a percepção da comunidade escolar. (Artigo apresentado como trabalho de conclusão de curso de Pós graduação em Educação e Direitos Humanos: Escola, Violência e Garantias de Direitos, da Universidade do Sul de Santa Catarina), 2017.

CARVALHO, S. G.; SANTOS, A. B. S.; SANTOS, I. M. A pandemia no cárcere: intervenções no superisolamento. Ciênc. saúde coletiva, Rio de Janeiro, v. 25, n. 9, p. 3493-3502, set. 2020. Disponível em: http:// www.scielo.br/scielo.php? script=sci_arttext\&pi$\mathrm{d}=\mathrm{S} 1413-81232020000903493 \& \operatorname{lng}=\mathrm{en} \& \mathrm{nrm}=\mathrm{iso}$. Acesso em: 17/11/2021.

Disponível em: htts:Ilg1.globo.com, acessado em 17/11/2021.

GRIGORENKO, Elena L; Sternberg, Robert J. Crianças Rotuladas - O que é necessário saber sobre as dificuldades de aprendizagem. Porto Alegre: Artmed, 2003. 
LIMA, J. L.; MELO, A. B. de; PERPETUO, C. L. Pandemia e a exacerbação das vulnerabilidades sociais: impactos na saúde mental. Akrópolis, Umuarama, v. 29, n. 1, p. 5974 ,jan./jun. 2021.

OLIVEIRA, B. R.; COELHO, J. I. F.; VIEIRA, M. F. Limites e possibilidades do uso das TDICs no processo de formação de professores na modalidade a distância: a experiência do Programa Escola de Gestores na Universidade Federal de Ouro Preto. Dialogia, São Paulo, n. 27, p. 65-78, set./dez, 2017.

VIEIRA, Márcia de Freitas; da SILVA, Carlos Manuel Seco. A Educação no contexto da pandemia de COVID-19: uma revisão sistemática de literatura. Revista Brasileira de Informática na Educação - RBIE. 28, 10131031, 2020. 


\section{NÚCLEO GESTOR E 0 PROCESSO DE INCLUSÃO DE ESTUDANTES COM NECESSIDADES EDUCATIVAS \\ ESPECIAIS: EM TEMPOS PANDÊMICOS EM UMA ESCOLA DE MARACANAÚ \\ Auriline Pinheiro Almeida ${ }^{1}$ \\ Leila Maria do Carmo Silva² \\ Rita Cristiane de Oliveira Comes ${ }^{3}$ \\ Tarcisio José Aquino Oliveira ${ }^{4}$ \\ Maria Eliene Magalhães da Silva 5}

\section{Considerações Iniciais}

O interesse pelo tema "O Núcleo Gestor como condutor do processo de inclusão de estudantes com

1 Graduada em pedagogia - UVA; Especialista em Planejamento Educacional - Faculdade Universo Salgado de Oliveira; Especialista em Docência do Ensino Superior - FACESMA; Coordenador escolar do Município de Maracanaú/CE. E-mail: ari.line@hotmail.com

2 Especialista em Educação Especial e Inclusiva - FSV; Especialista em Gestão Escolar e Coordenação Pedagógica - FA7; Graduada em Pedagogia - UECE Professora do Município de Maracanaú/CE; E-mail: leilaliberato@gmail.com

3 Especialista em Docência do Ensino Superior - Facesma; Gestão Escolar e Coordenação Pedagógica - Falc; Psicopedagogia Clínica, institucional e hospitalar - CETREDE; Gestão e Políticas Públicas - Fak. Graduada em Licenciatura Pedagogia - UVA; Professora da rede municipal de Maracanau há 33 anos e de Fortaleza há 20 anos; Atualmente Diretora Acadêmica da Faculdade Cesma de Maracanaú- FACESMA; E-mail: cristiane@facesma.com.br

4 Graduado em Pedagogia - UVA; Especialista em gestão escolar pela UDESC -Universidade de Santa Catarina Especialista em docência do ensino superior- FACESMA; Professor do município de Maracanaú/CE; E-mail tarcisioquino@gmail.com

5 Graduada em Ciências da Religião - ICRE; Graduada em Pedagogia - UVA; Graduada em História UVA; Graduada em Letras/Português - UFC; Especialização em psicopedagogia - UFC; Especialização em Ensino religioso - FINOM; Especialização em História para Formação de Professores de Quilombos - UFC; Mestra em Educação - UFC; Professora de Caucaia e São Gonçalo do Amarante; E-mail: elienemariajacyra@gmail.com 
Necessidades Educativas Especiais em uma Escola de Maracanaú", surgiu a partir de um interesse do Grupo pela temática da educação inclusiva, aliada ao interesse em gestão escolar.

Considerando a escola como um espaço para todos que ao longo dos anos vem se transformando através de uma busca de uma Gestão Democrática e Participativa. A busca por uma escola nos moldes democráticos vem modificando cada vez mais as relações sociais, mas a realidade é que ainda convivemos com práticas discriminatórias e de exclusão. A luta por uma gestão democrática e participativa foi reafirmada na maior legislação do país, a Constituição Federal de 1988 e ressaltada na Lei de Diretrizes e Bases da Educação Nacional - Lei n.o 9394/96.

Acreditando que a escola, enquanto espaço democrático deve buscar caminhos possíveis para criar ações que permitam a oferta de um ensino de qualidade que incluam todos no processo educativo, independentemente de suas limitações, e valorize as suas potencialidades frente aos desafios da aprendizagem. Cresce a responsabilidade do gestor escolar e o seu compromisso em estimular práticas inclusivas, criar mecanismos para que a escola se torne mais humanitária, justa, democrática e verdadeiramente inclusiva.

Compreendemos que a gestão escolar tem uma função essencial na condução do processo de inclusão escolar, inclusive em gerir uma escola que atenda a todos os estudantes, sem nenhuma discriminação e preconceito e isso se fez imprescindível nos tempos de pandemia. A escola deve ser vista como espaço para todos. Um espaço democrático, que abraça a diversidade, 
onde haja a busca de práticas inclusivas que atenda às necessidades de uma política pautada nos direitos humanos, por um ensino de qualidade.

A pesquisa teve como objetivo geral analisar a atuação do Núcleo Gestor na inclusão de estudantes com necessidades educacionais especializadas em tempos de pandemia. Determinamos como objetivos específicos conceituar a inclusão como direito dos estudantes matriculados em todos os níveis e modalidades de ensino; investigar sobre a prática da inclusão na escola pesquisa em tempos pandêmicos; identificar como a Gestão Escolar agiu com os demais profissionais da escola, para manter o vínculo destas crianças.

Como metodologia foi utilizada a pesquisa bibliográfica e o estudo de caso que segundo Severino (2016, p.56) diz "se tratar de uma pesquisa qualitativa". Quanto a pesquisa bibliográfica Marconi e Lakatos (2011, p.98) esclarecem que "tem importância fundamental para a realização de um trabalho científico, pois proporciona embasamento teórico do objeto da pesquisa de tudo o que foi escrito e publicado e esteja relacionado ao tema em estudo".

Os casos a serem objetos de pesquisas devem ser significativos em deferência do tema escolhido e devem ser analisados de forma rigorosa e imparcial.

O estudo de caso é caracterizado pelo estudo profundo e exaustivo de um ou de poucos objetos, de maneira a permitir conhecimentos amplos e detalhados do mesmo, tarefa praticamente impossível mediante os outros tipos de delineamentos considerados. (GIL, 2010, p. 73) 
O Núcleo gestor como agente de inclusão das crianças com necessidades educacionais especiais em tempos pandêmicos

Ao abordar o tema da inclusão na Gestão, não podemos deixar de falar da Gestão democrática da escola pública, tal política que ganhou destaque em termos de legislação a partir da Constituição Federal de 1988, que a incorpora como um princípio do ensino público na forma da lei. Sendo a primeira Constituição na história do Brasil a definir que o ensino deve ser ministrado com base no princípio da gestão democrática, em seu Art. 206, revela que o ensino será ministrado com base nos princípios de igualdade de condições e permanência na escola e da gestão democrática do ensino público.

A gestão democrática é aqui compreendida, en-
tão como um processo político no qual as pesso-
as que atuam na/ sobre a escola identificam, de-
liberam e planejam, encaminham, acompanham,
controlam e avaliam o conjunto das ações vol-
tadas ao desenvolvimento da própria escola na
busca da solução daqueles problemas. (SOUZA,
2006, p.125)

Podemos afirmar que a gestão democrática irrompe paradigmas e alcança mudanças nas rotinas das escolas, baseando-se nos processos decisórios com a participação de todos. Mas para isso acontecer, é preciso que haja cooperação de toda a equipe escolar e comunidade, não só em eventos escolares ocasionais ou em reuniões de pais, mas em situações que demandam tomadas de decisões no que se refere às questões políticas educacionais e pedagógicas da escola.

O princípio da gestão democrática foi regulamentado, em parte, na Lei de Diretrizes e Bases da Educa- 
ção (LDB 9.394/96), ao definir que os sistemas de ensino determinem as normas da gestão democrática do ensino público na educação básica, conforme as suas particularidades. O artigo 3.o, inciso VIII, vem reafirmar o princípio de gestão democrática do ensino público, expresso no artigo 206 inciso VI da Constituição Federal de 1988.

É exatamente em uma escola democrática que os sujeitos conhecem e reconhecem seus direitos e deveres, assim como as leis que fazem parte da nossa sociedade. Esta escola democrática é efetivada pela participação de todos que dela fazem parte. É imperativo reconhecer quais as ações de uma gestão democrática para que a inclusão escolar ocorra e seja verdadeiramente garantido o direito dos estudantes com necessidades especiais de aprendizagem. Conforme Machado (2000, p.125), "a ação do gestor da escola para tornar uma realidade a inclusão, ocorre na busca pela constante capacitação dos docentes, troca de experiências e ideias, valorização do trabalho coletivo". Podemos afirmar que através de planejamento, obtenção de resultados positivos com a comunidade escolar, elaboração do Projeto Político Pedagógico (PPP), interação da comunidade escolar, administrar os recursos humanos e financeiros, gerenciais e adequar o currículo básico nacional.

Considerando que estudantes com necessidade especiais de ensino e aprendizagem, têm direito a uma escola acessível e o Grupo Gestor tem o papel de construir condições para que a escola garanta este direito, quando se pensa em acessibilidade, não é apenas nas condições físicas, mas em todas as condições, inclusive nas condições pedagógicas. Segundo Dutra e Griboski 
(2005, p.67), "o gestor para colaborar com a inclusão deve mobilizar a sociedade, a comunidade escolar, os órgãos competentes e deve ainda acompanhar as transformações dos sistemas educacionais, deve contribuir para qualidade de ensino e aprendizagem, e sempre responder aos anseios daqueles grupos que têm sido excluídos do processo educativo".

De acordo com Carneiro (2006, p.38) "o papel dos diretores escolares é criar condições adequadas para a inclusão de todas as crianças, assim, transformando o ambiente escolar em uma gestão participativa e democrática. $O$ gestor deve envolver toda a equipe escolar de modo a atender as necessidades dos alunos."

Conforme a literatura estudada observamos a grande relevância do Grupo Gestor na inclusão destes estudantes e o quanto a escola pública, enquanto escola democrática de direito deve estar apta para realizar a inclusão, principalmente em momentos que se faz necessário ir além dos muros da escola, já que neste período foi necessário quebrar paradigmas para manter os vínculos com profissionais, comunidade e estudantes.

\section{Análise dos Resultados}

A pesquisa foi realizada na Escola Municipal de Ensino Fundamental Pensando e Construindo, no município de Maracanaú-CE, localizada Rua Pereira Silva, 1442- Jardim Jatobá- Maracanaú - CE, que possui em suas instalações uma sala de atendimento educacional especializado.

A escola foi criada há vinte e quatro anos, com a finalidade de promover uma educação de qualidade para os alunos da comunidade do Jatobá, considerada 
como uma área vulnerável. A escola, consolidou-se no bairro onde o nível de violência que antes fazia parte do cotidiano diminuiu consideravelmente. Nossa escola vem galgando os seus melhores índices na aprendizagem dos estudantes e atualmente podemos considerar a nossa unidade escolar como referência de aprendizado. Inclusive muitos pais tiram os filhos de escolas particulares para buscarem vagas dentro da nossa escola. Contamos com um excelente quadro de professores comprometidos e que se envolvem dentro das condições possíveis com a problemática da nossa comunidade escolar. Atualmente contamos com 349 alunos, matriculados em 16 turmas.

Desde o dia 18 de março de 2020, estamos trabalhando de forma remota, no entanto, a escola nunca deixou de funcionar, sempre esteve aberta à comunidade, sob a responsabilidade da Gestão Escolar. Após as férias dos professores, organizamos os grupos de WhatsApp por turmas e retornarmos sempre com contato com os alunos, foi construído um sistema de conversa e de estudo, foi feito também com grupo dos alunos do AEE, sempre tivemos a preocupação se todos eles estariam presentes e participando neste grupo. Consolidamos com muito sucesso o trabalho com os estudantes de todos os níveis, inclusive o AEE. Tivemos algumas dificuldades no início, para que os pais de adaptassem às novas tecnologias e ao ensino remoto, bem como com os professores, mas as dificuldades foram vencidas, com muito estudo e acolhimento.

Realizamos frequentemente buscas dos alunos que não estão participando, através de ligações, visitas domiciliares, chamadas de vídeo para resgatar os vínculos. 
De acordo com dados obtidos com a gestão da escola estão matriculados atualmente e participando ativamente de forma remota, em seu quadro de discentes da sala de AEE, vinte e três estudantes, com laudos, que comprovam a necessidade de atendimento especializado.

A proposta deste trabalho baseia-se na pesquisa sobre o papel da gestão escolar diante da inclusão dos alunos especiais em tempos pandêmicos, como também analisar as principais dificuldades encontradas para manter o vínculo com os estudantes. Realizamos entrevistas com o Gestor Geral da Escola, com a professora da Sala de AEE e com uma mãe de um dos alunos que mais participou durante o período pandêmico, que faz acompanhamento com a Sala de AEE. Os entrevistados responderam de forma muito receptiva, todas as entrevistas foram realizadas de forma remota, através de aplicativos de mensagens instantâneas.

Durante a pandemia conforme a fala da professora o atendimento foi realizado de acordo com as condições que o sistema apresentou, ou seja, a maioria dos recursos materiais foi dos professores e em relação aos vínculos, foi feito um trabalho de conscientização com as famílias, sobre a importância de manter a rotina de estudos para que não houvesse retrocesso na aprendizagem, mas as dificuldades foram muitas.

O trabalho do professor competente é ajudar todos os alunos a construir aprendizagens significativas. A forma como se propõe as situações de ensino e de aprendizagem é determinante para se conseguir ou não uma aprendizagem significativa. A construção de aprendizagens significativas implica que todos os alunos tenham uma predisposição favorável para aprender, atribuam 
um sentido especial às experiências de aprendizagem e estabeleçam relações substanciais com as novas aprendizagens e o que já sabem. (COLL, MARCHESI, PALACIOS, 2004, p. 15).

Questionada sobre as dificuldades a professora relata que, o uso dos recursos tecnológicos, tanto pelas famílias, como pelos profissionais da educação, dificultou um pouco a realização do trabalho, visto que alguns pais e profissionais, não tinham muita afinidade com a tecnologia.

O movimento no sentido das escolas inclusivas procede, em grande medida, do campo da educação especial e se propôs a atingir uma mudança profunda na educação que seja capaz de integrar todos os alunos. Tal situação obriga mudanças profundas se o que se pretende em última análise é que todos os alunos, sem nenhum tipo de discriminação, atinjam o máximo desenvolvimento possível de suas capacidades pessoais, sociais e intelectuais. (COLL, MARCHESI, PALACIOS, 2004, p. 15)

Quanto a motivação para o trabalho, a professora informa que não houve motivação material, tais como, disponibilização de dispositivos pela rede de ensino, incentivos financeiros, mas houve muito incentivo emocional por parte de seus gestores.

Sobre a participação dos estudantes, a profissional informa que não houve evasão, que a gestão escolar realizou um trabalho ótimo de busca ativa, não apenas com os estudantes do AEE, mas com todos matriculados na escola. Relata ainda que a maioria dos estudantes participava de forma significativa, considerando o contexto, podendo afirmar que alguns até surpreenderam nas participações. 
Podemos observar na fala da professora que, houve boa vontade e esforço no atendimento, acolhimento, na manutenção do vínculo e inclusão destes alunos. Podemos nos embasar na fala de Cury (2006, p.3) quanto à inclusão que afirma: "a primeira garantia é que ele esteja inscrito no coração de nossas escolas cercado de todas as condições. Nesse sentido, o papel do gestor e de todos que fazem a escola é o de assumir e liderar a efetivação desse direito no âmbito de suas atribuições".

Entrevistamos uma mãe e o filho que participaram ativamente neste período pandêmico e trazemos aqui a suas percepções.

Quanto à relação com a gestão da escola na pandemia: A nossa da gestão da escola no período para anemia foi boa foi de bom proveito, porque antes disso nós só iríamos eu pensava a gente só ia buscar meu menino na escola e não sabia o que era vista em sala de aula e já agora no tempo da pandemia Foi até melhor porque nós ficarmos sabendo que ele tava dando lá na escola principalmente na sala do aee aí foi boa porque estreitou nossa relação entre professor e pais né e alunos também porque os alunos tiveram mais contato agora com os professores porque ficou um a um não ficou um professor para turma toda falando e agora ficou de o professor falar com próprio aluno se quisesse.

Percebemos que a mãe se mostrou satisfeita com a proximidade que houve com a gestão e com os professores neste período, mesmo as aulas acontecendo de forma remota, houve uma aproximação do estudante e da família com estes profissionais.

Analisando a fala da mãe podemos citar Mantoan (1997, p.43) que observa o seguinte no processo educativo, os recursos físicos e os meios materiais cedem 
sua prioridade ao desenvolvimento de novas atitudes e formas de interação, exigindo mudanças no relacionamento pessoal e social e na forma de cumprir os processos de ensino e aprendizagem, e a inclusão.

Quanto a dificuldade para manter o vínculo do filho na escola:

"Não Tenho dificuldades para manter o vínculo dele com a escola, ele aceita bem se eu falar para ele que tem algo da escola ele aceita de boa eu não tenho muita dificuldade quanto a isso não professor."

Quanto aos pontos positivos neste período:

"Os pontos positivos que eu achei o contato diário com o que ele faz em sala de aula vindo tarefinhas de todas as semanas aumentem para de fazer aí eu fico sabendo o que ele faz na escola não fica só aquela coisa aí buscar meu filho chegar lá trazer para casa não aqui eu já sabia o que ele faz em sala de aula e também o contato se nós tivermos alguma dúvida, nós podemos questionar a qualquer professor daí aí ficou ótima, ficou bom esse período aí."

Quanto às dificuldades de aprendizagens do filho neste período:

"Dificuldades emocionais tive muitos professores, eu tenho um comércio pequeno aqui, mas atende a pessoas diariamente diretamente. Aí fica aquela coisa a gente ter que tá usando álcool em gel lavando as mãos para manter todo aquele cuidado para que o vírus não entrasse em casa e para quem não pegasse no meu filho, aí foi difícil, foi difícil, mas passamos por essa fase aí graças a Deus."

Perguntamos sobre a motivação no período:

"Principalmente as tarefas venham tarefas que eu fazia vídeo com ele que ele adorava ele adora aquelas 
de receita então ele fica maravilhado. Tem que ajudar ter que fazer algo quando era dia de fazer receita para escola ele não me deixava em paz tem que estar fazendo, tem que fazer, ele queria participar ele quer participar. Esse foi um dos principais pontos que eu achei bom para que ele participasse de alguma coisa da escola."

Percebemos na fala da mãe a importância das atividades escolares para o filho, quanto o mesmo valoriza o trabalho dos professores e sente-se incluído no processo, o que está implicitamente ligado ao planejamento pedagógico direcionado para a manutenção dos vínculos com os estudantes. $O$ planejamento das atividades escolares deve ser voltado para que haja a inclusão destes alunos em todos os projetos da escola. Carvalho (2007, p.68) recomenda uma nova maneira no ato de planejar e assim um menor grupo decide para haver uma maior participação de todos no processo, principalmente daqueles que adquiriram mais experiência e conhecimentos na educação e demonstra compromisso com o interesse do coletivo.

Conforme relata o Gestor Geral da Escola, ficamos felicíssimos em ver o retorno à alegria de cada um quando postava as suas atividades e isso nos deixou com vontade de fazer mais e a nossa escola está ganhando a presença efetiva desses meninos com a consciência dos professores e dos funcionários da Gestão em construir essa educação no momento tão difícil em que estamos superando a da pandemia do covid-19.

Observamos nas falas do Gestor que muitas foram às ações desenvolvidas pela Gestão Escolar no período pandêmico, todas as ações desenvolvidas no espaço escolar em prol dos alunos com necessidades educativas especiais, para que os mesmos não perdessem os vín- 
culos com a escola. Dentre os pontos que destacamos podemos citar importância da construção coletiva do processo de inclusão na escola, através de vários recursos tecnológicos e físicos, como visitas às residências dos estudantes, atividades com a participação da família, bem como a necessidade dos professores buscarem novos recursos e metodologias para manter os vínculos.

\section{Considerações Finais}

Podemos concluir com o estudo de caso que o Grupo Gestor de uma escola regular que atende estudantes com necessidades educacionais especiais em tempos pandêmicos, pode criar ações para promover a inclusão, mesmo diante da situação da escola, que teve que adaptar as metodologias, para atender os estudantes de forma remota. Observamos que gestor tem o compromisso de ajudar no processo de inclusão de todos os alunos, independente a necessidade de cada um, e da situação que a inclusão deva acontecer, presencialmente ou remotamente, "Construir uma educação emancipadora e inclusiva é instituir continuamente novas relações educativas numa sociedade contraditória e excludente" (BRASIL, 2004, p.18).

Sabemos que existem dificuldades na construção de uma escola inclusiva que ainda precisa ser melhor em muitos aspectos, a escola Municipal de ensino regular, apresenta condições para o atendimento dos alunos com necessidades educacionais de aprendizagem, com qualidade, observamos a infraestrutura, os materiais pedagógicos, professores qualificados e atendimentos em projetos, que mesmo a distância foram bem conduzidos. 
A gestão atua de forma ativa junto às famílias, professores e todos que fazem a escola para que ocorra o processo de inclusão, realizando acompanhamento das atividades pedagógicas, dos grupos de WhatsApp, realizando buscas ativas. Podemos concluir, que a dedicação de professores, Gestores e Famílias, fez toda a diferença para a inclusão e manutenção dos vínculos dos estudantes da sala de AEE, e que a gestão escolar fez toda a diferença neste processo.

\section{Referências}

. Constituição (1988). Constituição da República Federativa do Brasil. Brasília, DF: Senado 1988.

Declaração de Salamanca e linhas de ação sobre as necessidades educativas especiais. Brasília. Ministério da Justiça/Secretaria Nacional de Direitos Humanos, 1994.

BRASIL, Ministério da Educação. Lei de Diretrizes e Bases da Educação Nacional. № 9394 de 20 de dezembro de 1996.

BRASIL. Programa Nacional de Fortalecimento dos Conselhos Escolares. Conselho Escolar e o respeito e a valorização do saber e da cultura do estudante e da comunidade. Brasília: MEC; SEB, 2004. v. 3.

CARNEIRO, Relma U.C. Formação sobre a gestão escolar inclusiva para os diretores de escolas da Educação Infantil. Tese- Universidade Federal de São Carlos, São Carlos, 2006.

CARVALHO, R. E. Educação inclusiva: com os pingos nos "is". Porto Alegre: Mediação, 2007.

COLL, MARCHESI, PALÁCIOS. César, Álvaro, Jesús; Trad. Fátima Murad- Desenvolvimento psicológico e educação: Transtornos de desenvolvimento e necessida- 
des educativas especiais. Volume 3. 2. ed. Porto Alegre: Artmed, 2004.

CURY, C. R. J. O direito à educação: um campo de atuação do gestor. Brasília: Ministério da Educação, 2006.

DEMO, Pedro. Introdução ao ensino da metodologia da ciência. 2.ed. São Paulo: Atlas, 1987.

DUTRA, CR, GRIBOSKI, GM. Gestão para inclusão. Revista Educação Especial, 2005. Disponível em http://corolx.Ufsm.br/revece/ceesp/2005/02/a1htm.Acesso em 29 de julho de 2020.

GIL, Antônio Carlos. Como Elaborar Projetos de Pesquisa. 5. ed. São Paulo: Atlas, 2010.

MACHADO, Maria Aglaê de Medeiros. Desafios a serem enfrentados na capacitação de gestores escolares. Em Aberto, Brasília, 2000.

MANTOAN, M. T. E. e Colaboradores. A Integração de Pessoas com Deficiência: contribuições para uma reflexão sobre o tema Ed. Memnon. Edições Científicas Ltda.: Ed. SENAC, São Paulo, 1997.

MARCONI, M. de A. LAKATOS, E. M. Metodologia Científica. 5. ed. São Paulo: Atlas, 2011.

PRODANOV, Cleber Cristiano. Freitas, Ernani César. Metodologia do trabalho científico [recurso eletrônico] : métodos e técnicas da pesquisa e do trabalho acadêmico. 2. ed. Novo Hamburgo: Feevale, 2013.

SEVERINO, Antônio Joaquim. Metodologia do Trabalho Científico. 24 Ed. Revista e atualizada. São Paulo: Cortez, 2016.

SOUZA, S. M. Z. Avaliação institucional elementos para discussão. Escolas democráticas: concepções,2006. Disponível em: http://gestores.mec.gov.br. Acesso em 16 de agosto de 2020. 


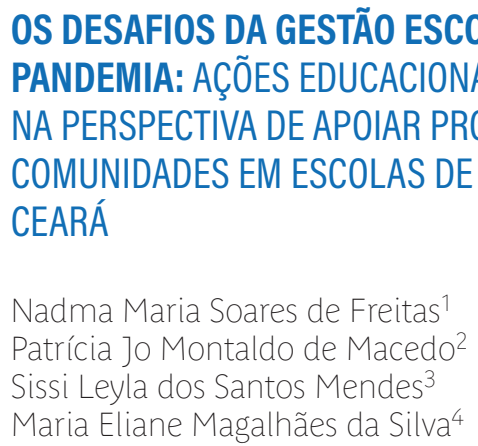

\section{Introdução}

Iniciamos o ano de 2020 com rumores de que havia chegado ao Brasil um vírus que já assolava as pessoas de um país distante - China. Não imaginávamos, porém, que em um curto espaço de tempo esse vírus atingiria a população brasileira de forma tão brutal a ponto de paralisar praticamente todos os setores do nosso país.

Esse texto aborda a realidade que a gestão escolar do Município de Maracanaú enfrentou e continua enfrentando diante do contexto pandêmico decorrente

1 Graduada em Pedagogia; Especialista em Gestão Escolar; Especialista em Gestão Escolar.

2 Habilitada em Administração Escolar; Graduada em Pedagogia, UECE; Especialista em Gestão Escolar.

3 Graduada em Pedagogia; Habilitada em Administração Escolar; Especialista em Educação Infantil; Especialista em Português e Inglês.

4 Graduada em Ciências da Religião - ICRE; Graduada em Pedagogia - UVA; Graduada em História UVA; Graduada em Letras/Português - UFC; Especialização em psicopedagogia - UFC; Especialização em Ensino religioso - FINOM; Especialização em História para Formação de Professores de Quilombos - UFC; Mestra em Educação - UFC; Professora de Caucaia e São Gonçalo do Amarante; E-mail: elienemariajacyra@gmail.com 
da COVID 19. Muitos foram e estão sendo os desafios enfrentados: mudanças de paradigmas sobre o que e como ensinar, paradigmas esse que gradualmente "são quebrados" conforme o aperfeiçoamento do professor (https://educere.bruc.com.br). Necessidade de se reinventar profissionalmente tendo que adentrar num mundo das novas tecnologias, o desemprego dos familiares dos nossos alunos, a dificuldade para nos conectarmos com os estudantes, e tendo em simultâneo, que enfrentar um cenário onde a quantidade de perdas era inimaginável diferente da nossa realidade habitual.

Diante desse cenário, foi necessário buscar mecanismos de apoio emocional para os professores, alunos e suas famílias, pois não podia deixar aqueles que acreditavam na Escola como espaço de referência e acolhimento perder a esperança. Era preciso enfrentar todos juntos esse momento. Então, a gestão das escolas utilizou-se de várias ações para minimizar os transtornos emocionais decorrentes desse contexto.

Foram realizadas entrevistas com professores, famílias, colaboradores das escolas e embasamento teórico, no intuito de apresentar ações realizadas tanto no espaço escolar quanto através de aplicativos, via internet, que possibilitaram o apoio de todos que fazem parte dessas escolas para o enfrentamento desse momento pandêmico.

A dinâmica do dia a dia na escola é bastante intensa e constantemente ocorrem desafios travados no campo emocional. Dessa forma, se faz necessário conhecer mecanismos e ações que possam auxiliar a gestão das escolas a lidar com essas questões para que a instituição possa garantir além da aprendizagem cognitiva, o respeito ao outro como ser humano. 


\section{Instituições: breve histórico}

A EMEIEF Cora Coralina está localizada na Rua Geraldo Nobre, $\mathrm{n}^{\circ} 1945$, bairro Alto Alegre II, no município de Maracanaú - Ce. A Escola atualmente tem 825 alunos matriculados e oferece as seguintes modalidades de ensino: Educação Infantil, Ensino Fundamental e Educação de Jovens e Adultos - EJA. A Gestão Escolar é composta por Diretora Escolar, uma Coordenadora Pedagógica e um Secretário Escolar. A Escola situa-se na zona urbana do município, considerado bairro de limite com o município de Fortaleza e a clientela assistida é composta por famílias carentes beneficiadas por Programas do Governo Federal: domésticas, diaristas, desempregados e trabalhadores autônomos.

A EMEIEF Professora Norma Célia Pinheiro Crispim está localizada à Avenida Juscelino Kubitschek, n.o 2295, bairro Jardim Jatobá no município de Maracanaú. A escola atende a 825 alunos distribuídos nos seguintes níveis de ensino: Educação Infantil (creche Pré I e II), Ensino Fundamental I (1.0 ao 5.0 ano) e Educação de Jovens e Adultos (EJA). O núcleo gestor é composto por uma gestora geral, duas coordenadoras pedagógicas, um coordenador administrativo-financeiro e uma secretária. A escola está situada na zona urbana do município e sua clientela é composta, em sua maioria, por famílias beneficiadas pelo Programa Bolsa Família: domésticas, diaristas e trabalhadores autônomos.

A EMEIEF Santa Edwirges tem seu nome como referência à santa protetora dos endividados sendo fundada em 3 de março de 1972, a partir da necessidade de alfabetizar os operários da Cerâmica Santa Edwirges. 
Em 1986 A EMEIEF Santa Edwirges passou a ter sede própria, e administração da Cidade de Maracanaú tendo como Prefeito Almir Freitas Dutra. Desde essa data até os dias atuais a Escola está situada na Rua Paulo Afonso n.o 1840, no Bairro Alto Alegre I, na zona urbana do município em uma área de comunidade muito carente que sobrevive praticamente da reciclagem, alguns trabalham na CEASA e outros são trabalhadores informais. Atualmente o Programa Bolsa Família é considerado a principal renda familiar da comunidade em questão. A escola atende atualmente a 212 alunos nos níveis da Educação Infantil (Pré I e II), Ensino Fundamental: séries iniciais(1.0 ao 5.0 ano) e séries finais(6.0 ao 9.0 ano). O núcleo gestor é composto por uma gestora geral, uma coordenadora pedagógica e uma secretária.

\section{COVID 19 - as escolas param}

Janeiro de 2020, estávamos na nossa rotina recebendo alunos e comunidade na escola, realizando eventos para acomodar os pais, procurando formas para melhorar o aprendizado das crianças, pois de acordo com Paulo Freire "ensinar não é transferir conhecimento, mas criar possibilidades para sua produção ou sua construção” (p.13). Professores realizando um belíssimo trabalho proporcionando atividades que possibilitaram a construção do conhecimento de maneira dinâmica e agradável, pais presentes e confiantes, servidores felizes no seu ambiente de trabalho e comunidade contente com a gestão das instituições.

Março de 2020, início de uma época marcada por muitas perdas oriundas de um vírus que não sabíamos sua real origem nem mesmo o grau de contaminação, 
estávamos perdidos e temerosos. Soubemos que tal vírus, COVID 19, que "começou a cidade na cidade de Wuhan na China, em dezembro de 2019" (http://butantan.gov.br/covid/butantan) causava uma infecção, a preocupação foi inerente. Porém, era num país muito distante do nosso, acreditávamos que jamais chegaria, ou poderia demorar demais para chegar aqui, até lá os cientistas já teriam conseguido um antídoto para controlar essa doença, afinal estávamos falando de um país das tecnologias, das ciências... Começamos mesmo sem acreditar que esse vírus chegaria tão rápido, a ensinar as crianças como se proteger com uso de máscara, jeito certo de espirrar, uso de álcool gel... Em menos de uma semana a triste notícia que a escola deveria fechar as portas.

Os anos de 2020 e 2021 estão sendo um grande desafio para a humanidade, todas as áreas foram afetadas, especificamente à educação. Considerando a necessidade de isolamento social como medida de enfrentamento à pandemia do Coronavírus, doença que assola o mundo, comprometendo inclusive a nossa saúde, medidas diferenciadas no sistema de ensino precisaram ser tomadas, seguindo as orientações da Organização Mundial da Saúde (OMS), como consequência, aconteceu o fechamento das unidades escolares determinado por decretos. A Secretaria de Educação de Maracanaú optou por estratégias alternativas de ensino. Dessa forma, desde o dia 18 de março de 2020 e prevalecendo até os dias atuais, estamos seguindo a Portaria da SME $0258 / 2020$, as aulas passaram a ocorrer na modalidade de ensino remoto, com atividades diárias, de segunda a sexta-feira, no app WhatsApp, as crianças foram adicionadas a grupos específicos seguindo a matrícula do 
ano atual, onde o responsável pela criança pode acessar usando aparelho celular, tablet ou computador. Ficamos longe fisicamente, porém próximos e presentes, seja através do aplicativo disponível e acessível pela comunidade ou pelas ações estratégicas criadas pela gestão escolar.

\section{O que fazer para seguir em frente?}

Em 17 de março de 2020 quando de fato precisamos nos distanciar, as notícias já eram assustadoras, ficamos abalados emocionalmente, vieram as medidas de enfrentamento e tivemos que nos reinventar, seguir com novas estratégias. A liderança da nossa gestão escolar nesse momento foi de fundamental importância, uma gestão com hábitos já enraizados de parceria, de proximidade intersectorial, de ações coletivas, de conquistas e valorização profissional, injetou em cada equipe um clima de união.

Baseados nos princípios da equidade, flexibilidade e inclusão foi adotado o ensino remoto como alternativa às práticas pedagógicas. Passamos a conviver com isolamento físico, mas com a mesma intensidade de parceria, o desafio era de todos, ser gestor de forma virtual, acolher as dificuldades e gerir problemas mantendo os distanciamentos não foram fáceis, porém, oferecemos o melhor suporte possível, com força e dinamismo, segundo os professores, em nenhum momento deixamos de ser presentes ou atuantes articulamos reuniões para informes e orientações, organizamos as salas de aulas virtuais em grupos de WhatsApp, rastreando todos os alunos e seus contatos, fizemos a busca ativa dos contatos indisponíveis, ofertamos material pedagógico para 
os professores montarem seus ambientes em casa, de forma que as crianças recebessem estímulos visuais durante as interações, sugestões de aulas foram oferecidas para que cada professor se adequasse e pudesse preparar um material de qualidade para as crianças, respeitando seus níveis e dificuldades.

Diariamente de forma presencial a gestão esteve na escola, ambiente físico, em escala de atendimento. Várias ações foram realizadas, livros foram distribuídos de forma organizada, por horários, por séries, da mesma forma famílias foram recebidas para entregas de cesta básicas, atividades impressas como recurso adicional foram ofertadas para que os prejuízos fossem amenizados. Parece muito, realmente é muito, pensando na pandemia que estava destruindo famílias, pondo fim em vidas e histórias, pegando de surpresa as pessoas que pensavam estar protegidas.

Entretanto, não podíamos parar, alguns espaços físicos foram transformados, respeitando todas as normas de segurança que o momento exigia, projetos sociais foram abraçados para acolher as necessidades da comunidade, principalmente a fome; ações coletivas para ajudar colegas em dificuldades foram gerenciadas; o Setor de Educação Especial/Inclusiva de Maracanaú elaborou orientações para o trabalho domiciliar dos professores do Atendimento Educacional Especializado (AEE).

A professora do Atendimento Educacional Especializado - AEE, com as coordenadoras pedagógicas, criaram alternativas para viabilizar uma maior interação entre os professores e o estudante com deficiência, primando pelo respeito à diversidade e o reconhecimento de cada um dos estudantes de acordo com suas potencialidades/habilidades e necessidades/dificulda- 
des como: chamadas online com a participação da família, reunião com os professores avaliando a real necessidade de adaptação de cada educando, assessoramento aos professores com materiais explorados durante as interações diárias, sugestões de possíveis adaptações necessárias aos estudantes com deficiência, principalmente no uso de atividades sensoriais para aqueles com dificuldades motoras (cadeirantes), há um trabalho contínuo no contato com os familiares dos alunos, para amenizar os impactos causados pela falta de relação com o grupo escolar.

A mediação com a família está sendo fundamental principalmente para aquele estudante que não possui autonomia para realizar as atividades sozinhas, viabilizando seu acompanhamento nas atividades propostas tanto com os professores da sala de aula comum, como as da professora do AEE.

Durante as aulas foram lançados desafios pedagógicos e as crianças receberam mimos kit com cadernos, lápis, biscoitos, doces, bombons, bolachas... Como incentivo para as crianças que realizassem as atividades online e para aqueles que não tinham acesso à internet deveriam pegar atividades xerocadas na escola e na devolução também ganhariam o kit, realizamos essas ações até os dias atuais.

A gestão esteve presente em todos os grupos de aulas remotas, sempre aparecendo para incentivar a participação nas aulas, para elogiar as lindas postagens, desejar melhoras quando alguém estava indisposto ou felicitar pelo aniversário, todo o esforço para que nenhum funcionário, aluno ou a comunidade deixassem de ser atendidos, nenhum membro das escolas deixou de ser mapeado. 


\section{Escola: Lugar de Aconchego}

No meio a perdas materiais, psicológicas, entes queridos, amigos próximos com o vírus, famílias passando fome, alunos sem acesso às tecnologias necessárias para assistir aulas remotas, comunidade chegando à escola a procura de comida, de atenção, de um olhar, de um abraço, mesmo que, apenas com os gestos, pais dizendo não ter paciência de ensinar seus filhos, outros querendo tirar a própria vida... Os pais iam buscar refúgio por a escola ser e sempre será o espaço de referência, jamais podendo fechar as portas na sua totalidade.

Lá estavam, nós gestores, na ponta precisando ter equilíbrio emocional mesmo nos momentos de desequilíbrio, buscando no nosso interior forças para transmitir àqueles que acreditam no nosso trabalho a esperança de um futuro melhor e de que nada estava perdido. Nossa preocupação ia além do cognitivo visto que acreditamos que o aluno precisa estar bem no sentido global para poder ter um bom desenvolvimento. Segundo Goleman "um indivíduo que consegue controlar suas emoções também consegue desenvolver melhor sua inteligência." (Goleman, Daniel Inteligência Emocional) Fomos, através da sociabilidade entrando em contradição com o momento que era de isolamento social, buscar meios para podermos ajudar a comunidade, a gestão acompanhou cada componente e cada situação, gerenciou os problemas de forma que soluções fossem pensadas coletivamente e direcionadas a cada família.

A união é um ponto primordial na nossa gestão, para momentos de sensibilização e fortalecimento da amizade, da fé e aspectos emocionais foram oferecidos 
aos professores encontros pelo Meet com psicólogos e profissionais da biodança, reflexões, palavras de conforto e força, o nosso grupo virtual de WhatsApp passou a ser a nosso ponto de encontro diário, nossa sala dos professores, nosso momento de desabafo, a comemoração de nossas conquistas, nosso choro ou nosso grito de medo, nossa chegada e nossa despedida do dia pedagógico, diariamente ofertamos mensagens de otimismo, de reconhecimento profissional e pessoal, aniversários foram lembrados e perdas foram inevitáveis, infelizmente doenças, demissões e mortes foram anunciadas, e de pessoas queridas precisamos nos despedir, realizar essa missão de ser porta-voz e manter o equilíbrio nesses momentos. Segundo uma professora da educação infantil "anunciar o fim de pessoas e relações exige muita coragem e sensibilidade, é momento de muita dor, uma mistura de sentimentos que esse grupo viveu, mas a gestão estava lá, para nos lembrar que a vida é feita de tudo isso", cada momento e cada pessoa tem o seu valor e precisamos nos reerguer, continuar nossos caminhos, a missão continua, pedagógica ou pessoal, fácil ou difícil, ganhando ou perdendo, nunca podemos parar.

Um exemplo de acolhimento aos professores, nesse momento de isolamento foi o Projeto Sala de Afetos, criado durante a pandemia da Covid 19, pelo psicoterapeuta e psicólogo educacional Renê Vieira Dinelli. Acolhendo professores, de modo a fortalecer a saúde mental dos educadores.

O projeto foi compartilhado na EMEIEF Cora Coralina, onde foi possível criar um espaço virtual de acolhimento e fortalecimento através de escutas empáticas, com trocas entre pares e metodologias afetivas, 
fazendo com que professores sintam-se cuidados. A Sala de Afetos é um lembrete de que tem alguém olhando para mim, enquanto professor. Mostra que o professor também precisa de um cuidado.

A experiência foi tão positiva, que foi compartilhada com outras escolas do Município de Maracanaú.

\section{Ações Fundamentais}

Todo brasileiro desde a infância tem seus direitos sociais subjetivos perante a Constituição Federal Brasileira no seu artigo 6.o que diz "são direitos sociais a saúde, a alimentação, o trabalho, a moradia, o transporte, o lazer..." (Brasil, 1990, Art.6.o), porém, no decorrer da pandemia com as ações governamentais voltadas para o combate ao vírus, houve um aumento significativo de pessoas em situação de pobreza extrema tornando o Brasil um dos maiores epicentros da fome devido ao impacto causado pelo Coronavírus.

Ao depararmos com pessoas passando necessidades resolvemos transformar o grupo de zumba da escola no PROJETO SOS PERIFERIA na coordenação de Lucas Alves e Rodney Júnior esse último professor de zumba da escola. Publicamos nas redes sociais: Instagram, TV, Facebook, WhatsApp o projeto e a que nos propomos. Foi feito parcerias com outros projetos como AUÊ DO AMOR, CUFA, MESA BRASIL e pessoas físicas, começamos a receber grandes doações de todo gênero e roupas usadas.

Com a chegada dos gêneros e apoio do secretário de educação da época, professor Marcelo Farias. Organizamos na escola uma cozinha solidária, com chefe de cozinha, nutricionistas e as mães do grupo zumba 
como voluntária para cozinhar as refeições. Passamos a atender não só a comunidade escolar como também a comunidade do entorno, além da comida feita foi entregue cestas básicas, chip social, cartão alimentação, kit higiene e lanches.

Tivemos a oportunidade de unirmos em prol dos menos favorecidos buscamos apoio de outras entidades solidárias como o ROTARY CLUB de FORTALEZA-BARRA na presidência do senhor Delberg Ponce de Leon - arquiteto, o membro da instituição o senhor Paulo César Queiroz Dias - engenheiro, mais trinta e quatro associados do clube e ex-alunos do colégio Santo Inácio, professores, amigos e gestores da escola com ajuda de recursos financeiro e material para mais uma ação de responsabilidade social:

Estávamos na escola quando uma mãe chegou chorando desesperadamente pedindo ajuda, ela estava em conflito em todos os sentidos, (lembramos que a Secretaria de Educação nos presenteou com um curso de mediação de conflitos a qual fez muita diferença nas nossas ações nos momentos atuais) bem, a senhora tomava remédio antidepressivo, estava sem alimento para dá aos seus filhos e sua casa era de taipa, com dois pequenos cômodos, coberta telhas gastas e plástico, terra batida e paredes caídas enfim espaço totalmente insalubre. No seu depoimento disse que nesse dia dormira muito para tomar o remédio, quando acordou seu filho (nosso aluno) estava segurando uma panela sobre sua rede para que as goteiras não a molhasse. Sensibilizados com a narrativa, resolvemos fazer uma campanha junto aos professores e amigos para levantar o quarto com tijolos e colocar telhas novas, reforçando a questão da segurança e evitando desmoronamento imi- 
nente. Foi demolida a casa antiga e construída uma linda residência. No dia da entrega grande foi a emoção da família, a mãe chorando dizia: "não tenho palavras para agradecer o que fizeram por mim, foi Deus que colocou todos vocês na minha vida muito obrigada mesmo..." essa ação e a satisfação de poder ajudar nos estimulará a continuar com nosso desejo de servir movidos pela solidariedade, força, amor e empatia.

\section{Esperança de Dias Melhores}

Viramos o ano apreensivos, o desejo de que tudo seria melhor confundia-se com o temor das novas variantes do coronavírus. $\mathrm{O}$ misto de sentimento era inevitável naquele momento, o número de mortes aumentando assustadoramente além dos altos índices de pessoas com situação de vulnerabilidade social.

Passamos por momentos difíceis e desesperadores, porém com uma fé inabalável em Deus e na Ciência. Especialistas realizaram inúmeras pesquisas com o vírus, testes e uma incansável busca para tirar o mundo da aflição acometida pelo COVID 19. Lá estavam nossos guerreiros na linha de frente salvando vidas, arriscando suas vidas, analisando, estudando, criando protocolos sanitários e obtendo respostas positivas em meio a negacionistas, descrença e mutações assustadoras do vírus. Em pouco tempo começou a aparecer indícios de vacinas eficazes, iniciando a fase de teste e nos aflorando a cada dia a esperança de voltarmos a nos abraçar, estar junto, ficar perto, sentir o outro passamos a entender e acreditar que a única saída seria imunização em massa através da vacina.

Sabendo da necessidade da vacina e preocupados com o pequeno número de pais cadastrados no site saú- 
de digital por motivo de não ter conhecimento tecnológico, não ter acesso à internet, não ter aparelho para esse fim ou até mesmo por falta de conhecimento do programa, resolvemos fazer uma campanha na escola para realizar os cadastros com hora marcada e obedecendo todo protocolo sanitário. Tivemos uma grande aceitação e grandes foram os agradecimentos e elogios pela iniciativa.

\section{Considerações Finais}

O período em que estamos vivenciando a Pandemia COVID 19 revisitou diversas reflexões e aprendizagens no universo escolar. Possibilitou a percepção de que a escola não é apenas um lugar onde se busca o conhecimento, mas também, um lugar onde se deve pensar e agir como seres humanos que precisam ser solidários e acolher a todos que adentram seus portões.

Percebeu-se que o ensinar e o aprender perpassam prioritariamente pelo sentir: sentir-se acolhido, seguro, compreendido e valorizado independentemente da realidade de cada um. A escola precisa ser um espaço de várias possibilidades e, assim criar condições de aprendizagem para seus alunos, mesmo quando a situação for desfavorável.

Apesar da gestão não estarem preparadas para enfrentar as adversidades que a pandemia trouxe as escolas citadas neste texto mostraram que com responsabilidade, boa vontade, profissionalismo, trabalho em equipe e com humanidade pode-se realizar mais do que a função social pretendida pelas instituições de ensino para isso se faz necessário que a gestão tenha o apoio da comunidade escolar, das famílias, das parcerias e 
da Secretaria de Educação, afinal ninguém trabalha sozinho.

Sabemos dos inúmeros desafios para se enfrentar, pois, a vida é feita de obstáculos e conquistas, algumas batalhas foram vencidas, mas a guerra ainda não acabou e o vírus continua a nos rondar. A gestão das escolas continuará a trabalhar em prol de seus alunos, servidores e da comunidade em seu entorno com a certeza de que, independente dos desafios, possuem ferramentas para criar as possibilidades de fazer seu trabalho cada dia melhor, a educação é a porta de entrada e de saída para um futuro igualitário, humano, justo, respeitoso e honesto, portanto, nossa grande responsabilidade perante a sociedade. Somos formadores de opiniões, temos o futuro dos educandos em nossas mãos. Por esse motivo não podemos desistir nunca.

\section{Referências}

FREIRE, Paulo. Pedagogia da autonomia: saberes necessários à prática educativa. 30. ed. São Paulo: Paz e Terra, 1996. (Coleção Leitura)

GOLEMAN, Daniel Inteligência Emocional. A Teoria Revolucionária que Redefine o que é Ser Inteligente. Tradução: Marcos Santarrita.Rio de Janeiro. Editora Objetiva Limitada, 2011, 420 páginas apud https://barcelonasuperficies.com.br/blog/inteligencia-emocional-na-escola/

Portaria da SME 0258/2020

Brasil.[Constituição(1988)]. Constituição da República Federativa do Brasil: promulgada em 5 de outubro de 1988. Ed. São Paulo: Saraiva , 1990. 
O DOCENTE E SUAS EMOÇ̃̃ES: NA BUSCA DE UMA

METODOLOGIA EM MEIO A PANDEMIA

Adriana Raisa Alves de Oliveira1
Jailson Moreira Lopes
Mariana Rodrigues Torres
M
lury Torquato de Almeida

Introdução

A busca por mecanismos de aprendizagem não é uma tarefa muito fácil, mas no atual cenário em que estamos vivendo, essa busca teve que ser rápida e de fácil execução, pois, por conta da COVID-19 o mundo inteiro teve que se recolher de forma repentina em seus lares buscando principalmente sua própria sobrevivência e de seus familiares.

Com o avanço das tecnologias em tempos "normais", surge atualmente a inerente necessidade de adquirir habilidades para utilização de equipamentos fora do ambiente escolar e consequentemente tornar as aulas ainda mais atrativas e interativas. O desenvol-

1 Graduada em Matemática /UECE. Especialista em Gestão Escolar e Coordenação Pedagógica/UECE. Professora efetiva da Educação Básica do Município de Maracanaú - CE

2 Graduado em Pedagogia/FA7. Especialista em Gestão Escolar e Coordenação Pedagógica/FMB. Professor efetivo da Educação Básica do Município de Maracanaú - CE

3 Especialista em Gestão Escolar e Graduada em Pedagogia - UECE Articuladora do Contraturno em Maracanaú/CE. Email: maritorresoficial@gmail.com

4 Graduado em Administração - FAK; Licenciado em Pedagogia - FAK; Especialista em Gestão de Projetos - ABED; Especialista em Psicologia Organizacional e do Trabalho - FAK; Especialista em Gestão Escolar - FAESL; Especialista em Docência do Ensino Superior - FAK; Especialista em Gestão e Tutoria - UNIASSELVI; Mestre em Gestão de Negócios Turísticos - UECE; Doutor em Ciências da Educação - USC/PY; E-mail: iuryt.almeida@gmail.com 
vimento de competências e habilidades ligadas à tecnologia é fator de grande importância na construção de novas ideias, na exploração do novo, das experiências adquiridas entre outros elementos que contribuem para o crescimento intelectual dos educandos. Partindo desse ponto, o presente artigo busca mostrar caminhos e vivências de Docentes da Educação Básica na investigação de Metodologias de ensino para suas aulas remotas durante a COVID-19 e, ao mesmo tempo, procurando cuidar de suas emoções nesse tempo pandêmico.

No atual momento, as Tecnologias Digitais de Informação e Comunicação estão sendo utilizadas de forma mais ativas para aplicação de aulas remotas, para conter a proliferação do vírus causada pela Covid - 19 . As unidades de ensino do mundo inteiro tiveram que aderir ao modelo de educação a distância, com o propósito de que os discentes não ficassem sem aula e acabam comprometendo ainda mais o seu desenvolvimento. Logo, uma metodologia adequada e bem executada poderia ser um caminho para que o ensino à distância e o aprendizado acontecesse de forma concreta e verdadeira.

O cotidiano no mundo inteiro não foi o mesmo após a existência desse vírus, pois, o choro e a dor, o medo de perder alguém e a angústia foram muitas vezes mostradas nos meios de comunicação, deixando o dia a dia ainda mais caótico. As consequências iniciais e assombros iniciais da COVID-19 foram bem expressas por Bittar (2020) quando diz:

A erupção do vírus surge, no século XXI, como a explosão de um vulcão. A princípio, a expansão da contaminação na China. Depois, na Itália. Em seguida, Espanha, França, etc. e Brasil. De 
forma cataclísmica, o vírus se espalha, gerando contaminação, e, espantosamente, faz o mundo parar. Em seguida, começam as fortes oscilações nas bolsas de todo o mundo, a depressão dos mercados e a desaceleração econômica. Afinal, começam as medidas de quarentena compulsória, de fechamento de fronteiras, de impedimento internacional de circulação de pessoas, até chegarmos às políticas setoriais compensatórias propostas pelos governos, como forma de lidar com os efeitos econômicos imediatos da disseminação do vírus, com riscos à saúde e à vida para milhões de pessoas, em todo o mundo. Para muitos, a única explicação possível vem à carreira do fatalismo fanático, e se proliferam as visões apocalípticas com as quais o 'fim do mundo' vem sendo invocado. (BITTAR, 2020, on-line)

O Docente no meio de tudo isso, passou a buscar mecanismos de aprendizagem ainda mais eficazes e tendo que lidar com seus medos e aflições durante esses tempos tão difíceis.

As profundas e gigantescas transformações metodológicas que vinham acontecendo a passos medianos, tiveram que apressadas no que diz respeito por boa parte dos educadores, que atualmente sofreram a revolução tecnológica e a globalização que exigem da educação uma nova atuação para um cenário social, e com isso nos levam alguns problemas, entre eles, podemos destacar o que trata este artigo, onde se parte da ideia do docente ter de procurar caminhos para conduzir suas aulas mesmo sem um material adequado, nenhum apoio financeiro e ainda ter o equilíbrio para cuidar do corpo e da mente. Partindo disso, questionamos: como o docente em tempos pandêmicos consegue buscar mecanismos de ensino e cuidar de suas emoções ao mesmo tempo? 
O presente artigo teve como objetivo verificar os impactos causados pela Covid 19 nos mecanismos de ensino para os docentes e suas dolorosas consequências emocionais. Relacionados a ele estão os seguintes objetivos específicos: conhecer os recursos utilizados pelos docentes durante as aulas remotas; investigar quais as adaptações e aprendizagens os docentes tiveram para executar as novas metodologias; identificar as emoções dos docentes e suas interferências no ensinar; analisar suas consequências emocionais para os docentes.

Para a construção desse artigo foi utilizada uma pesquisa bibliográfica exploratória com abordagem qualitativa.

\section{Tecnologia e o novo jeito de fazer escola}

O uso de recursos tecnológicos em atividades escolares exige do docente, uma dedicação para se apropriar dessas ferramentas, mais tempo, apoio dos seus gestores e de toda a escola, para que os resultados e objetivos desejados sejam obtidos por todos. No atual cenário que estamos vivendo, onde tivemos que nos recolher em nossos lares, nós professores tivemos a mudança do espaço, da comunicação e do tempo com os alunos. Passamos por uma grande alteração na rotina em que fomos da sala de aula presencial em que estávamos acostumados a conviver, para o virtual, onde tivemos que aprender a reaprender. Como afirma Perrenoud (2000),

formar para as novas tecnologias é formar o julgamento, o senso crítico, o pensamento hipotético e dedutivo, as faculdades de observação e de pesquisa, a imaginação, a capacidade de memo- 
rizar e classificar, a leitura e a análise de textos e imagens, a representação de redes, de procedimentos e de estratégias de comunicação. (PERRENOUD, 2000, p. 128)

Introduzir tecnologia na escola é fazer a inclusão dos alunos como parte de um todo, que produz, que pensa, que observa e que pesquisa, na busca de estratégias para cada vez mais ser autor da sua própria história. Pensando nisso, educador e tecnologia fazem parte do mesmo time e suas forças se somam para que o ensino aconteça de forma verdadeira e jamais ser em lados opostos onde um rejeita o outro ou poder ser substituído em suas atividades. No atual cenário, presenciamos a junção desses dois times trabalhando juntos, para ajudar no planejamento, diminuindo o esforço e reduzindo o tempo gasto.

É de suma importância acharmos novos caminhos e abordagens pedagógicas que finalizem o distanciamento das tecnologias e escola. Percebemos isso quando tivemos que nos adaptar e nos colocamos em permanente situação de diálogo, cooperação e sobretudo, nos aproximando cada vez mais do contexto dos alunos. Sobre esse aspecto, Kenski (2012) salienta que:

a escola hoje não deve servir apenas para preparar pessoas para exercer funções sociais e adaptar-se às oportunidades sociais existentes, ligadas à empregabilidade cada vez mais fugaz, mas sim, pautar-se pela intensificação das oportunidades e autonomia dos alunos em relação à busca de conhecimentos, da definição de caminhos, da liberdade para que possam criar oportunidades e serem os sujeitos da própria existência. (KENSKI, 2012, p. 66) 
Além de diminuir a distância nos tempos atuais em que nos apresenta, o uso das tecnologias pode ajudar a transformar a escola em um lugar de exploração de culturas, de realizações de projetos, de conhecimentos constantes, de investigação, de grandes debates e senso crítico, tornando o aluno protagonista da sua história. Escolas fechadas de forma inesperada gerou a necessidade de assumir emergencialmente o ensino remoto. Discriminado por Behar (2020), esse modelo de aulas remotas tornando-se:

[...] uma modalidade de ensino que pressupõe
o distanciamento geográfico de professores e
alunos e foi adotada de forma temporária nos
diferentes níveis de ensino por instituições edu-
cacionais do mundo inteiro para que as ativida-
des escolares não sejam interrompidas. Dessa
forma, o ensino presencial físico precisou ser
transposto para os meios digitais. (BEHAR, 2020,
online)

Logo, o mundo passou a adotar o sistema de ensino remoto. De forma, direta ou indiretamente, os impactos no contexto social causados pelo fechamento das escolas refletiu não apenas nos muros da escola, mas entre pais e alunos. Transformar a sala de aula, apesar do distanciamento, em um espaço de reflexão e de aprendizagem ativa, onde discentes e docentes se unem e passam a serem parceiros de um mesmo processo de construção e aprofundamento de conhecimento.

Nesse mesmo cenário, o uso de forma diferenciada e inovadora das ferramentas tecnológicas, a exemplo, podem ajudar os docentes no processo de ensino e aprendizagem dos alunos, indo além das disciplinas ministradas. Contudo, para desfrutar e utilizar das vantagens do uso das novas tecnologias de forma ins- 
titucional não basta apenas fazer o uso da mesma, mas também observar quais são as mais importantes e adequadas a realidades de seus educandos no meio em que eles vivem e quais eles demonstram mais interesse e facilidade em aprender o que está sendo exposto para eles.

Vivemos hoje momentos difíceis, mas com muita luta e persistência estamos aprendendo a conviver com esse "novo mundo", onde precisamos manter um certo distanciamento entre as pessoas, onde ficamos mais em casa, onde trabalhamos de forma remota, onde aprendemos a usar máscaras e a cuidar mais de se e das outras pessoas ao nosso redor. Percebemos que apesar de estarmos passando por isso há um certo tempo e ter já aprendido bastante com a nova rotina, a escola continua insubstituível quando falamos de formação das novas gerações para os embates das exigências postas pela sociedade moderna ou pós-industrial. Sobre as novas tecnologias, Mercado (1999, p. 27), afirma que

As novas tecnologias criam novas chances de reformular as relações entre alunos e professores e de rever a relação da escola com o meio social, ao diversificar os espaços de construção do conhecimento, ao revolucionar os processos e metodologias de aprendizagem, permitindo à escola um novo diálogo com os indivíduos e com o mundo (MERCADO, 1999).

Compreendemos que houve uma expansão das tecnologias digitais bem antes da COVID-19 e trouxeram muitos benefícios para a sociedade, por meio dessas ferramentas, existem diversas maneiras das pessoas se comunicarem (SILVA,2019). Esses avanços dos recursos nos permitiram e nos permitem ministrar 
aulas de forma remota durante a pandemia e ter uma aprendizagem mais significativa, só sendo possível por conta da qualidade das ferramentas digitais que tornaram isso possível mesmo que de forma remota.

Por conta da COVID-19, o ensinar e o aprender tiveram que mudar de lugar, de forma inesperada e rápida. Os docentes tiveram que transformar seus lares para poderem ministrar suas aulas e, além disso, tiveram que buscar formas diferentes para que o ensino chegasse no lar de seus alunos, por conta da pandemia. Pensando em deixar o conteúdo mais claro e acessível, o uso das tecnologias digitais tem auxiliado nesse sentido, com suporte para tirar suas dúvidas e sendo desafiado constantemente. Nessa mesma linha, Garcia et al. (2020, p.09) afirma que:

Aprender é uma atitude cuja competência precisa ser desenvolvida. A pró atividade, a inventividade, a responsabilidade e o compromisso são condutas que precisam ser construídas e incentivadas. No ensino remoto, o estudante terá de ser gradativa e continuamente incentivado e promovido para a aprendizagem.

Nos distanciarmos das pessoas de forma repentina não é uma tarefa agradável para muitos e de forma repentina torna isso ainda pior e doloroso, assim como em muitas profissões, professores e alunos passaram e ainda passam por isso; ter que aprender fora do ambiente escolar. Para tentar diminuir esse distanciamento, as tecnologias tentam criar elos entre educador e educando, para que as metas antes da pandemia estabelecidas sejam alcançadas de forma positiva, em relação ao rendimento e que as dificuldades encontradas sejam sanadas. 
No cenário em que vivemos, a utilização das novas tecnologias foram um grande desafio, avaliando assim, ao baixo uso de ferramentas e plataformas digitais pelos docentes (VAILLANT; ZIDAN; BIAGAS, 2020), que muitas vezes não por dúvida para o seu acesso ou por não dominar as diversas ferramentas disponíveis para utilização escolar. Além do que, segundo Ries, Rocha e Silva (2020) a falta de hábito com o uso das tecnologias refletiu na forma com que os professores disponibilizavam o material de estudo de forma inadequada nas plataformas tecnológicas utilizadas para interagir com os alunos, conduzindo assim um possível prejuízo ao ensino. Isso nos leva a fazer uma reflexão sobre a necessidade da capacitação tecnológica dos professores, no mesmo instante em que sua metodologia de forma presencial e dentro dos muros da escola deu lugar a uma prática virtual com o uso de ferramentas digitais, para que essas ações contribuam no "uso das novas tecnologias e metodologias ativas na sua práxis, principalmente em casos nos quais não foi possível a habilitação prévia para substituição de aulas presenciais por aulas através de meios digitais." (RIES; ROCHA; SILVA, 2020, p. 16).

O apoio dos sistemas de ensino e as suas instituições escolares nesse período, tem uma importância significativa para que o ensino remoto não se distancie tanto do ensino presencial. Neste aspecto, e com a mesma finalidade de manter as atividades educacionais durante o período de isolamento social como dito anteriormente, muito instituições tiveram que adaptar seus conteúdos programados antes de forma presencial para o online, adotando assim o ensino remota como saída para enfrentar o distanciamento. Não é uma ta- 
refa fácil, refazer os planejamentos e tentar de alguma forma direcionar os conteúdos para plataformas online para as interações com os alunos. Apesar de todos os entraves e desafios, atividades como essas são cruciais para tentar minimizar os prejuízos neste período de isolamento social.

\section{Aulas Remotas E Seus Desafios}

No Início Da Pandemia E Do Isolamento social, muitas dúvidas vieram à mente de muitos professores, autoridades, especialistas e muitas pessoas da sociedade, como poderíamos fazer o ensino acontecer mesmo ocupando outros espaços, onde grande parte dos sistemas de ensino não estavam preparados para um surto como esse de tamanha proporção que arrasou o mundo no início do ano de 2020 e até os tempos atuais, levando a uma paralisação global. Assim, a utilização das tecnologias digitais associadas ao ensino remoto são de extrema importância para enfrentar as grandes demandas emergenciais.

Para os docentes, o processo de ensino e aprendizagem nas aulas tiveram que ter adaptações para que os recursos pudessem ser utilizados e meios digitais fossem executados de forma rápida, precisa e de fácil execução e isso não foi uma tarefa muito fácil para muitos educadores, ter que se familiarizar com as tecnologias para conseguir dar suas aulas à distância poderiam ser um dos maiores problemas. Os métodos de comunicação utilizados por muitas escolas, atividades enviadas pelas redes sociais, em específico o WhatsApp, aplicativos de videoconferência, fotos das atividades e entre outras ferramentas que antes não eram utiliza- 
das para o ensino, acabou sendo sua principal fonte de comunicação entre escola e aluno. Muitos professores estão trabalhando muito mais para planejarem suas aulas em formatos digitais e adotar metodologias ativas para que o mesmo interaja cada vez mais e que o ensino aconteça de forma verdadeira. Notamos também que no desenrolar dos acontecimentos, uma grande parceria surgiu de forma ainda mais presente, uma parceria entre escola e família, que mesmo enfrentando tantas dificuldades nesses tempos difíceis como, desemprego, dificuldade de acesso e falta de recursos, muito deles colaboraram para que as crianças pudessem participar das atividades escolares. Também tivemos que nos confrontar com a dificuldade de acesso, por parte de algumas famílias onde tiveram que ir às escolas pegarem atividades impressas de forma presencial para que as crianças pudessem acompanhar as aulas que estavam sendo ministradas pela da internet. Troca de informação e de forma proveitosa, é essencial e de grande importância para que o processo possa acontecer.

Tecnologias e metodologias ativas favorecem o processo de ensino e aprendizagem de forma mais eficaz e autônoma, voltadas principalmente para realidade onde vivenciamos e com foco no desenvolvimento humano, nos leva a caminhos verdadeiros de crescimentos em todos os sentidos. Ter uma linguagem de fácil compreensão no meio digital não é uma tarefa de fácil execução, mas que precisou ser aplicada pelos docentes para haver uma comunicação a distância de qualidade, onde não houvesse nenhum tipo de prejuízo.

Fica bem nítido, quando percebemos que houve uma revolução educacional, sabemos que ainda precisamos caminhar muito e aumentar nossa compreen- 
são sobre essas ferramentas tecnológicas e utilizarmos ao nosso favor, mas ela se mostra eficiente e o quanto precisamos cada vez mais nos atualizar para poder acompanhar seu avanço. Quando voltarmos às aulas presenciais, jamais esqueçamos que podemos sim, utilizar essas ferramentas para uma melhor qualidade em nossas aulas.

\section{Professor e sua saúde mental}

A pandemia causada pela COVID-19 nos trouxe danos irreparáveis, tanto na perda de familiares, amigos, como na forma econômica, social, física e mental. Falando nisso, podemos trazer essa realidade para a área da educação, onde estamos propícios ao adoecimento mental, pois além de ter que nos reinventarmos para procurar caminhos para que o ensino ocorra, notícias de mortes nos chegam a todo instante pelos meios de comunicação, aumento dos casos de contágios, pressões das escolas, além da vida pessoal, filhos, atividades domésticas e outras responsabilidades que lhe são impostas (SHAW, 2020).

Segundo Moreira e Rodrigues (2018), desenvolver alguns transtornos é possível no ambiente em qual você trabalha e outras doenças nesse mesmo contexto, podendo ser uma das causas por conta do convívio com outros colaboradores, por conta da gestão, além da grande das pressões contínuas para que o trabalho seja executado de forma mais eficaz para se obter resultados mais rápidos. As incertezas, estresse, ansiedade, depressão e outras doenças mentais, são doenças que muitos professores vêm sofrendo diante de dias tão incertos e medos ainda mais constantes, o que leva a uma 
síndrome do esgotamento mental e físico (ARAUJO et al., 2020).

Pensar na saúde mental é tão importante quanto a saúde física e ela precisa constantemente de cuidados, mantendo-a estável e saudável. Ho et., al (2020), fugir um pouco da realidade pode ser um caminho para mantê-la forte mesmo em períodos de crises emocionais ou algo externo que tenha abalado, essa fuga poderia fortalecer a saúde mental de qualquer pessoa.

Existem várias atividades que podem nos ajudar a manter nossa mente saudável e forte emocionalmente para lidar com os vários acontecimentos da nossa vida como, correr, fazer uma boa caminhada, praticar atividade esportiva, ter momentos mais em família, fazer reflexões para si, é muito importância e procurar fazer aquilo que gosta de realizar entre outras atividades.

Assim como falado em algumas páginas anteriores deste presente artigo, por conta da mudança do ensino presencial para o ensino remoto e sua mudança do local de trabalho, os docentes são empurrados ou até mesmo coagidos a se adequarem às novas formas de atribuir o seu trabalho, tendo assim um novo perfil profissional e, implicando nas novas exigências para que os resultados sejam atingidos e com interações que para muitos, não se tinha quaisquer tipos de domínio para a execução nas suas aulas remotas. Fatores como esses podem gerar graves problemas à saúde mental dos docentes.

O professor e sua urgência de se adaptar e se reinventar, mediante ao atual momento em que a educação se encontra devido à COVID-19, muitos professores estão com a sensação de mal-estar por conta dos desafios impostos por esse cenário, pois muitos não conseguem 
acompanhar essa nova rotina e a forma de se trabalhar remotamente. Rápida adaptação dos professores, recursos tecnológicos e aplicação de metodologias ativas podem ser algumas das demandas escolares. Esse mal-estar docente para Pachiega e Milani (2020) é causado por essas novas formas das relações das práticas pedagógicas associada a tecnologia, as novas demandas do mundo que não estão no poder dos docentes e discentes, e essa identidade docente.

Sobre o agravamento na saúde mental dos docentes, Souza (2021) ressalta que, ocasionados pelo atual formato de trabalho. No atual cenário pandêmico, algumas causas desse agravamento dos educadores estão diretamente ligadas com a falta de apoio da gestão e relações interpessoais insatisfatórias, inexistência de tempo para desfrutar um descanso em muitos casos atendendo alunos fora do seu horário de trabalho, alunos desinteressados pelo aprendizado e cobranças de desempenho e qualidade no processo de ensino e aprendizagem.

Impactos psicológicos e psiquiátricos causados pela COVID-19 e seu adoecimento mental, de acordo com Brooks (2020) e Carvalho (2020) em seus levantamentos e estudos por essa temática, geram grandes problemas e desconforto de fácil visualização como, humor triste e deprimido, falta de concentração, dificuldade de ter atenção e de memorizar as coisas, tomada de decisão se torna algo demorado e de grande dificuldade, impaciente e agressivo com as pessoas, dor de cabeça constante e alteração do sono.

Dedicação ampliada de suas funções acrescidas à comunidade escolar e às famílias, essa é atual missão do professor atualmente, ultrapassando os muros 
da escola e indo além da sala de aula, não que antes isso não acontecia, contudo, agora está mais visível, de modo a garantir assim uma maior interação e articulação entre escola e comunidade (SILVA e NASCIMENTO, 2020).

Sabemos que estudos e teorias sobre o atual momento que estamos vivendo causados pela pandemia da COVID-19 e consequentemente sobre o estado mental de muitos educadores causados por vários motivos citados anteriormente ainda são primários, por se tratar de um fenômeno completamente novo para essa geração e precisa ser estudado, mas já acendem um sinal de alerta para grandes implicações consideravelmente negativas, aponta o autor Schmidt (2020) em seus estudos sobre "Saúde Mental e Intervenções Psicológicas durante a Pandemia”. Ainda temos que aprender muita coisa sobre tudo isso que estamos vivendo e compreender o quanto é importante pararmos um pouco, nos conhecer melhor e cuidar de nossa mente.

\section{Metodologia}

A pesquisa foi realizada utilizando a metodologia qualitativa ao nível de autopercepção e revisão bibliográfica.

A finalidade da pesquisa qualitativa é colher elementos que norteiam a compreensão dos comportamentos, das motivações e de atitudes de um grupo de pessoas, que no caso em questão são os professores, buscando perceber o ponto de vista dessa classe. Nesse sentido, Denzin e Lincoln (2006) dizem que a pesquisa qualitativa compreende uma abordagem interpretativa do mundo em que seus pesquisadores investigam as 
coisas em suas perspectivas naturais, buscando achar os fenômenos em que as pessoas atribuem significado.

No que tange a pesquisa bibliográfica, Dalbério e Dalbério (2009, p. 167) afirma que: “[...]o pesquisador deve tomar cuidado com a fidedignidade e validade científica das informações [sob o risco de] incorrer em possíveis incoerências e contradições causadas por material de baixa credibilidade". O que nos faz ser criteriosos nas informações e autores apresentados neste artigo.

\section{Considerações finais}

O presente artigo teve como objetivo verificar os impactos causados pela Covid-19 nos mecanismos de ensino para os docentes, conhecer os recursos utilizados, investigar as adaptações dos docentes em relação às aulas remotas para se apropriar de metodologias e identificar as emoções dos docentes ao longo desse processo.

Sabemos que a pandemia veio como um divisor de águas para determinar quem estava disposto a aprender de forma relâmpago os mecanismos e desafios que as tecnologias trazem e quem foi obrigado a se adaptar ao novo formato de aula e recursos utilizados para que o ensino não fosse ainda mais prejudicado por conta do isolamento social.

Os impactos emocionais e suas dolorosas consequências causados pela pandemia e as perdas irreparáveis que boa parte da população sofreu, apenas teremos a real dimensão quando o "novo normal" com sua rotina transformada pelas cicatrizes pandêmicas começar a se ajustar conforme as necessidades iniciarem como 
antes. Tais impactos causados nos mecanismos de ensino se devem pelo fato da maioria dos docentes não terem as habilidades necessárias para acessarem os mais diferentes recursos disponíveis nas plataformas virtuais. $O$ docente teve que se reinventar para conseguir administrar os recursos e utilizá-los da forma correta.

Os recursos utilizados ao longo do isolamento social são: as redes sociais, em específico o WhatsApp, aplicativos de videoconferência, fotos das atividades e entre outras ferramentas que antes não eram utilizadas para o ensino, que culminou como sendo a principal fonte de comunicação entre escola, aluno e os responsáveis.

O isolamento social tem abalado consideravelmente a saúde mental dos professores. A ansiedade e exaustão pelo excesso de trabalho e por perder de certa forma a privacidade dos lares. Hoje, a qualquer momento alunos têm acesso ao contato dos professores principalmente por meio do WhatsApp, o que tem causado frustrações e dificuldades diárias, o que compromete a saúde psicológica dos docentes.

Contudo, a adaptação do "novo normal", mesmo com todas as dificuldades de acesso, o pouco conhecimento das tecnologias, as emoções em constantes oscilações, a extensa rotina online e o medo de muitos perderem o emprego, faz com que o ensino remoto comprometa ainda mais o emocional dos educadores. Diante do que apresentamos, é necessário buscar modos mais apropriados para lidar com as demandas dos profissionais da educação. Por isso, para garantir uma saúde mental mais equilibrada, a ajuda profissional é indispensável. 


\section{Referências}

ARAÚJO, F.J.O et al. Impactof Sars-Cov-2 and its Reverberation in Global HigherEducationand Mental Health. PsychiatryResearch, V. 288, P. 112977, 2020. Disponível em: https://www.ncbi.nlm.nih.gov/pmc/articles/ PMC7152919/ .Acesso em:11 de setembro 2021.

BEHAR, P. A. O Ensino Remoto Emergencial e a Educação a Distância, 2020. Disponível em: https://www. ufrgs.br/coronavirus/base/artigo-o-ensino-remoto emergencial-e-a-educacao-a-distancia/ . Acesso em: 16 de agost. 2021.

BITTAR, E. C. B. GenJuridico. Coronavírus: uma pandemia para rever as patologias sociais do cotidiano, 2020. Disponível em http://genjuridico.com. br/2020/04/13/coronavirus-pandemia-patologias-sociais/\#_ftn1. Acesso em: 02 agosto 2021.

BROOKS, Samantha. O impacto psicológico da quarentena e como reduzi-lo: revisão rápida das evidências. The Lancet, v. 395, p. 912-920. 2020.

DALBERIO, O.; DALBERIO, M. C. B. Metodologia Científica: desafios e caminhos. São Paulo: Paulus, 2009.

DENZIN, N. K. e LINCOLN, Y. S. (Orgs.). O planejamento da pesquisa qualitativa: teorias e abordagens. 2. ed. Porto Alegre: Artmed, 2006. p. 15-41.

GARCIA, T. C. M. et al. Ensino remoto emergencial: proposta de design para organização de aulas.Caderno de Ensino Mediado por TIC. Natal, 2020.

HO, C. S., Chee, C. Y., \& Ho, R. C. (2020). Mental Health StrategiestoCombatthe PsychologicalImpactof COVID-19 Beyond Paranoia andPanic. Ann AcadMed Singapore, 49(3), 155-160. doi: https://pubmed.ncbi.nlm. nih.gov/32200399/. Acesso em 10 setem. 2021.

KENSKI, Vani Moreira. Educação e Tecnologias: O novo ritmo da informação. Campinas, SP. Papirus, 2007. 
MERCADO, Luís Paulo Leopoldo. Formação continuada de professores e novas tecnologias. Maceió: EDUFAL, 1999.

MOREIRA, D. Z.; RODRIGUES, M. B. "Saúde mental e trabalho docente”. Estudos de Psicologia, vol. 23, n. 3, 2018.

PACHIEGA, Michel Douglas; MILANI, Débora Raquel da Costa. Pandemia, as reinvenções educacionais e o mal-estar docente: uma contribuição sob a ótica psicanalítica. Dialogia, São Paulo, n. 36, p. 220-234, set./dez. 2020.

PERRENOUD, Philippe. Dez novas competências para ensinar. Porto Alegre: Artmed, 2000.

RIES, E. F.; ROCHA, V. M. P.; SILVA, C. G. L. Avaliação do ensino remoto de Epidemiologia em uma universidade pública do Sul do Brasil durante pandemia de COVID-19. Scielo em Perspectiva, 2020. Disponível em: https://preprints.scielo.org/index.php/scielo/preprint/ download/1152/1736/1818 . Acesso em: 24 agost. 2021.

SCHMIDT, Beatriz. Saúde mental e intervenções psicológicas diante da pandemia do novo coronavírus (COVID-19). Estud. psicol. Campinas, 2020.

SHAW, K. Collegesexpand VPN capacity, conferencingtoanswer COVID-19. Network World (online), Apr 2, 2020. Disponível em: https://www.networkworld.com/ article/3535415/colleges-expand-vpn capacityconferencing-to-answer-covid-19.html . Acesso em: 10 agost. 2021

SILVA, A. P. S. Diagnóstico Do Uso Das Tdics Nas Escolas Públicas Da Zona Urbana Do Município De Angicos/RN - 2019. Universidade Federal Rural do Semi-árido, disponível em:https://repositorio.ufersa.edu.br/handle/ prefix/2438 . Acesso em: 16 de agos. de 2021.

SILVA, Andrey Ferreira. Saúde mental de docentes universitários em tempos de pandemia. Physis, Rio de Janeiro, v. 30, n. 2, 2020. 
SILVA, Regina Célia Ribeiro da; NASCIMENTO, Dandara Lorrayne do. Trabalho docente na rede municipal de São Paulo no contexto da pandemia de Covid-19. Educação Pública, v. 20, n. 32., ago. 2020.

TORRES, A. C. M.; ALVES, L. R. G.; COSTA, A. C. N. Educação e Saúde: reflexões sobre o contexto universitário em tempos de COVID-19. Scielo em Perspectiva, 2020. Disponível em: https://preprints.scielo.org/index.php/ scielo/preprint/view/640/885 . Acesso em:10 agost. 2021.

VAILLANT, D.; ZIDAN, E. R.; BIAGAS, G. B. Uso de plataformas e ferramentas digitais para o ensino da Matemática. Ensaio: aval.pol.públ.Educ., Rio de Janeiro, v. 28, n. 108, p. 718-740, set. 2020. Disponível em: https:// www.scielo.br/j/ensaio/a/FqJdDMbX7FdGg3TYPmfqSBh/?lang=es . Acesso em: 24 agost. 2021.

ZAIDAN, Junia de Mattos; GALVÃO, Ana Carolina. COVID19 e os abutres do setor educacional: a superexploração da força de trabalho escancarada. In: AUGUSTO,

Cristiane Brandão; SANTOS, Rogerio Dultra dos (orgs.). Pandemias e pandemônio no Brasil. São Paulo: Instituto Defesa da Classe Trabalhadora, 2020. 
A FAMÍLIA E 0 ENSINO REMOTO: OS DESAFIOS EDUCACIONAIS E EMOCIONAIS EM TEMPOS DE PANDEMIA, NA VISÃO DAS FAMÍLIAS NAS AULAS REMOTAS

\author{
Almir Pereira dos Santos ${ }^{1}$ \\ Aurileda de Lima² \\ Jenivando Lira Braz ${ }^{3}$ \\ lury Torquato de Almeida ${ }^{4}$
}

\title{
Introdução
}

A educação assim como vários outros setores, não é mais a mesma, com a chegada da pandemia e diante de um vírus altamente letal, conforme estudos científicos e pelo número de óbitos registrados em todo mundo, muitas mudanças aconteceram e transformaram as vidas de milhões de pessoas em todas as partes. Essas alterações afetam pessoas de várias formas, físicas,

1 Graduado em Letras - UEMA; Especialista em Gestão Escolar UDESC; Professor do município de Maracanaú/CE.

E-mail: almirsantos_45@hotmail.com

2 Especialista em Gestão Escolar (UECE) e Psicopedagogia Clínica e Institucional (Faculdade Maciço de Baturité); Graduada em Pedagogia (UVA); Professora efetiva da Educação Básica do Município de Maracanaú/Ceará. E-mail: aurileda.lima@hotmail.com

3 Especialista em Gestão Escolar (FAK), Docência do Ensino Superior (FAK), Educação Infantil ( FAK). Graduado em Pedagogia e Licenciatura em Matemática (UVA); Professor efetivo da Educação Básica do Município de Maracanaú/Ceará e PACATUBA/Ceará. E-mail:vando_lira@yahoo.com.br

4 Graduado em Administração pela FAK com Registro no CRA/CE de № 12.183, Especialista em Gestão de Projetos pela ABED. Licenciado em Pedagogia pela FAK. Especialista em Psicologia Organizacional e do Trabalho pela FAK. Especialista em Gestão Escolar pela FAESL Especialista em Docência do Ensino Superior pela FAK. Especialista em Gestão e Tutoria pela Uniasselvi. Mestre em Gestão de Negócios Turísticos pela UECE. Doutor em Ciências da Educação pela USC/PY. E-mail: iuryt.almeida@gmail.com 
mentais e emocionais, e alterou o curso "normal" das atividades escolares, as emoções despertadas, em especial, o processo educacional, e consequentemente a forma de ensinar no Brasil, assim como em todo mundo.

Como tudo que é novo, esse "novo normal", nomenclatura muito utilizada com a chegada do Vírus da Covid 19 (Coronavírus). Surgiram também as necessidades de mudanças no comportamento da sociedade, seja de forma voluntária ou compulsória, como as medidas adotadas pelos governos em forma lockdown, ou isolamento social, atitude essa, para tentar garantir a contenção da doença. Com essas ações por parte dos órgãos governamentais, todos os setores públicos e privados, tiveram que se reinventar na sua forma de prestar serviços à sociedade, sejam eles essenciais ou não. Reaprender é a palavra mais falada com o surgimento da pandemia, todos tiveram que se reinventar, a viver diante da nova normalidade.

Diante da suspensão de várias atividades presenciais tidas como não necessárias, e com o fechamento das escolas na sua forma tradicional (presencial), as aulas remotas surgem como alternativas mais seguras diante do atual cenário. Vários setores investiram em novas alternativas para manter seus serviços, e com as escolas não poderiam ser diferentes, encontrar alternativas que torne seguro o processo educacional, manter a qualidade do ensino, e ainda a participação efetiva dos alunos, é o maior dos dilemas. As escolas passam a adotar dentro de suas condições, tecnologias que conectem os alunos aos conhecimentos que antes eram passados de forma presencial, nas salas de aula, sentindo toda aquela atenção e calor humano dos professores e colegas de classe. 
É nesse sentido, que tentaremos aqui, avaliar, ou mensurar os danos sentidos diretamente pelos alunos e suas famílias, desde o momento em que passaram a conviver "trancados" dentro de casa, quais os desafios, as principais dificuldades, as emoções vividas e principalmente o que os alunos sentiram com essa "nova" forma de estudar, e o que pais sentem em relação à aprendizagem de seus filhos, e o que esses pensam sobre o ensino remoto? E verificar os maiores desafios enfrentados pelas famílias, no acompanhamento do ensino-aprendizagem dos filhos nas aulas virtuais.

Em virtude das mudanças ocorridas na vida de todos, pensar em um ensino remoto, parece ser não a única metodologia viável, mas sem dúvida a mais segura para transmitir as aulas e minimizar os prejuízos educacionais, já sentidos, dos alunos diante de um fato tenebroso, que ameaça a saúde(vida) de discentes e docentes indivíduos diretamente ligados no processo ensino-aprendizagem. Enxergar a visão deles, alunos, o depoimento de suas famílias em relação ao novo "ensino remoto" ou híbrido, como já é proposto, é passo importante na retomada das aulas, até porque, as escolas precisam adquirir informações que possam permitir traçar um perfil do nível dos alunos em termos emocionais e da qualidade da aprendizagem na forma aplicada nesse período.

Observar as evoluções, os dramas, os anseios, as incertezas e as garantias que essa nova metodologia possa atingir ou não, a qualidade do ensino, a presença e assiduidade dos alunos, o apoio dos pais, enfim são pontos cruciais que precisam ser considerados, para termos uma visão da profundidade dos danos emocionais e principalmente intelectuais, que a pandemia 
causou, e ainda vai causar no processo ensino-aprendizagem, na visão daqueles que estão na ponta do processo educacional a família.

\section{A pandemia}

De acordo com informações adquiridas através da Organização Pan-Americana da Saúde," a descoberta da covid-19, trata do dia 31 de dezembro de 2019, a Organização Mundial da Saúde (OMS) foi alertada sobre vários casos de pneumonia na cidade de Wuhan, província de Hubei, na República Popular da China. Tratava-se de uma nova cepa (tipo) de coronavírus que não havia sido identificada antes em seres humanos".

Em janeiro de 2020, autoridades chinesas confirmaram um novo tipo de coronavírus que já se espalhou por toda parte. Segundo ainda a fonte de pesquisa, o vírus é a segunda principal causa de resfriado comum (após rinovírus) que, nas últimas décadas, muito raramente causavam doenças mais graves em humanos". (Organização Pan-Americana da Saúde - OPAS)

Com o avanço do vírus, fronteiras foram fechadas, e como um efeito cascata, países, estados e municípios foram se isolando, e isolando através de decretos seus habitantes do convívio social, todos os serviços são suspensos, exceto os essenciais, e esses nos rigores de higiene e segurança. Nessa onda do isolamento social, todos os setores tiveram que se adaptar ao agora, "novo normal”.

\section{A Educação e a transformação}

Com todos os acontecimentos o processo educacional também não é mais o mesmo, com a ameaça 
pandêmica de alta letalidade as mudanças eram inevitáveis, era preciso reaprender uma nova forma de viver em isolamento em todas as partes, e por milhões de pessoas. As mudanças não eram mais uma opção, era questão de sobrevivência. A modificação no novo modo de viver afeta o comportamento e o cotidiano de todo o curso "normal" das atividades escolares deixa de existir, e dispositivos já conhecidos passam a ter nova utilização, e integram agora o processo educacional, a forma de ensinar no Brasil, e no mundo. Reaprender a viver é a palavra-chave, a pandemia tira todos do trilho, a normalidade agora é o "Novo Normal".

Avaliar as consequências emocionais e os prejuízos educacionais sofridos pelos alunos, durante o período da pandemia, não é uma tarefa fácil, principalmente quando se fala de alunos de escolas públicas e de uma comunidade já muito carente de recursos financeiros, culturais e com pouco acesso às novas tecnologias. É um trabalho que exige uma pesquisa direta com os entes familiares envolvidos nesse processo. Não tem como perceber de forma clara, que mudanças aconteceram no âmbito familiar em relação à educação dos filhos, se não questionarmos quem sentiu, viu e acompanhou diariamente lado a lado, todas as dificuldades de nossos alunos em participar das aulas e atividades propostas pelos professores.

De um lado está a escola com a estrutura que lhe possível, toda a equipe de gestores, professores e coordenadores envolvidos no processo educacional, pensando na melhor e mais viável forma de repassar aos alunos todos os conteúdos já planejados, sem eles terem tanto prejuízo, além dos que serão inevitáveis, como a presença diária nas salas de aulas, ao lado pro- 
fessores, sempre presentes na hora da dúvida, e o convívio social entre os próprios alunos. Certamente esse ponto em especial, a falta de contato presencial nas salas de aulas, seja de longe o maior problema que os alunos enfrentaram, pois, nesse instante se instala outro grande dilema, o distanciamento social. Imaginar como ficaria a cabeça dessas crianças, adolescentes e jovens diante deste afastamento, especialmente, quando falamos de uma comunidade pobre, em que a escola é vista, não apenas como um lugar para "educar", transmitir conhecimentos, mas como espaço onde seus filhos ficam enquanto os pais precisam trabalhar. No entanto, essa parceria presencial entre escola e comunidade foi quebrada, e agora os pais passam a assumir o papel de "professor adjunto", e essa "nova" função não parece ser fácil, principalmente, quando lidamos com pais que em boa parte, são semi alfabetizados.

\section{O dilema e o caminho}

A grande questão era saber como adaptar as aulas para minimizar os danos na educação dos alunos, o que fazer para que o ensino-aprendizagem não ficasse totalmente comprometido. As escolas ficaram diante de um grande desafio, como lidar, como levar o conhecimento até os alunos, para garantir transmissão dos conteúdos e manter a qualidade do ensino, sem comprometer a saúde de todos os envolvidos. A tecnologia então é a forma utilizada, para levar às aulas, as casas dos alunos, através de ferramentas que exigia das famílias um mínimo de estrutura tecnológica, para ter acesso aos conteúdos das aulas, além do conhecimento das ferramentas utilizadas. 
Além dos fatos citados em relação aos alunos e suas famílias, tem também os professores, que não estão imunes às consequências causadas pelo afastamento social em virtude do coronavírus, eles também tiveram que mudar seus hábitos, costumes e toda uma rotina, para se adaptar ao dito "novo normal" e com essas mudanças apareceram também os problemas emocionais e físicos. De acordo com pesquisa realizada pelo Instituto Península " 7 em cada 10 professores já havia mudado muito ou totalmente suas rotinas; A preocupação maior estava na saúde dos seus familiares e na disseminação de informações de combate ao vírus, se comparado à interação remota com os estudantes; • Redes Federais, Estaduais e Municipais começavam a paralisar suas aulas presenciais; enquanto as Particulares já buscavam formas de manter o suporte à distância; A organização da vida familiar e o estudos passavam a ocupar posição importante na rotina dos docentes; e já surgiam os primeiros sinais de impacto sobre a saúde mental".

Não bastassem os impactos causados na rotina, no modo de vida de todos, conforme relatado na pesquisa, ainda tem a questão econômica, os prejuízos talvez irreparáveis, que certamente essa pandemia causaria. Conforme o economista Ricardo Paes de Barros, em estudo elaborado, à Folha de S. Paulo, "Um estudo do Insper (Instituto de Ensino e Pesquisa) sobre o impacto da perda de aprendizado neste ano ao longo da vida dos estudantes aponta que os jovens podem perder $R \$ 42,5$ mil de renda se os conteúdos não forem repostos e eles seguirem para o mercado de trabalho com esses déficits. "Não foi planejado, não houve transição para esse novo modelo. Então, houve perdas e precisamos olhar agora para elas". 
Portanto, conforme se percebe os professores também tinham dilemas pessoais que precisavam ser observados, respeitados e resolvidos. E como garantir aos alunos, o menor dos prejuízos em relação à transmissão dos conteúdos, para assegurar o ensino-aprendizagem com a mesma qualidade de antes, no ensino presencial. Como preparar esses jovens, para que não tivessem perdas substanciais, quando forem lançados ao mercado de trabalho. $O$ desafio maior era garantir que todos os alunos tivessem acesso aos conteúdos das aulas, mas para isso é preciso antes que os professores estivessem emocionalmente estáveis para aplicabilidade de uma nova metodologia de ensino, o ensino remoto, e que não fosse somente aceitável, mas que fosse eficiente e eficaz, de modo a assegurar o menor prejuízo possível. Para produzir o efeito esperado, que mostre realmente resultados na forma esperada, é preciso que todos os alunos tenham as mínimas condições de acesso às tecnologias utilizadas neste contexto. E essa condição, em se tratando da comunidade em que a escola esteja inserida, é um problema que não impede, mas dificulta a eficácia dos resultados. Alternativas precisavam surgir na tentativa de assegurar, que todas as atividades fossem acompanhadas pelo máximo de alunos possíveis. Os alunos que não possuíam celulares, ou esses não fossem compatíveis para receber dados através seus aparelhos de celular, precisariam obter as atividades propostas pelos professores, por outros meios, que não o virtual. Quando indagados aos professores sobre o acompanhamento dos alunos as aulas remotas, a assiduidade e o feedback das atividades propostas, foram quase unânimes em relação à participação dos alunos ... me sinto um pouco decepcionada, pois boa parte dos 
alunos não participam das aulas de forma nenhuma, falta compromisso dos pais com a aprendizagem dos filhos". Sobre o que poderia ser feito para não comprometer a aprendizagem dos alunos, a sugestão é a busca ativa dos que não estão envolvidos nos estudos, conversar com os responsáveis para relatar a situação a qual eles(alunos) se encontram. O problema é que a busca ativa também só poderia ser realizada de forma remota em função da pandemia, do isolamento social imposto, para evitar possível contaminação do vírus da Covid-19.

Quando realizamos os questionamentos juntos aos pais e alunos, sobre como eles estão vivenciando o atual momento, diante das novas metodologias educacionais aplicada de forma mais intensa através de aulas remotas, transmitidas via celular, os alunos foram taxativos em suas respostas, $86,9 \%$ dos entrevistados confirmaram que querem voltar as aulas presenciais, que sentem dificuldades em estudar em casa, mesmo que às vezes tenha ajuda dos pais no acompanhamento das atividades, enquanto $13,1 \%$ afirmaram que estão gostando da nova forma de ensino, no entanto, sentem-se também preocupados, ansiosos e às vezes tristes em função de não estarem indo para a escola, do convívio com os outros alunos. Questionado sobre como se sente estudando em casa, um aluno do 7.0 ano do ensino fundamental afirma,“... estou preocupado porque eu quase não estou entendendo o conteúdo, mas estou tentando e acabo ficando preocupado com medo de não passar de ano”, já outro do 9. ano," Eu nunca sei se as respostas estão certas, e às vezes queria poder ter o ensino dos professores". Na visão de $59,6 \%$ dos alunos que responderam ao questionário proposto, dizem sentir-se angustiados por não ter a presença dos professores, 
mesmo com acesso aos equipamentos tecnológicos(celular/computador) e internet disponível em casa, não é a mesma coisa, principalmente quando enfrentam dúvidas em determinados assuntos. Nas respostas uma boa parte dos estudantes alegaram que sentem dificuldades de estudar em casa, pois geralmente fazem as atividades sozinhos, sem o apoio dos pais ou familiares, o que é sem dúvida outro fato que pode afetar a qualidade do aprendizado dessas crianças e jovens, já muita enfraquecida. Aliado às angústias e dificuldades expostas pelos alunos, acrescenta-se ainda a baixa frequência desses durante as aulas remotas. "Além do desafio de utilizar várias ferramentas tecnológicas na tentativa de melhorar e obter uma participação mais ativa foi pensado em primeiro momento em estruturar um horário para transmissão das aulas, pois a maioria dos alunos não possui seu próprio celular, e só poderia participar, realizar as atividades, tirar dúvidas e fazer as devidas correções, quando os pais chegavam do trabalho, e com isso os horários ficaram mais extensos que nas aulas presenciais", relata uma professora.

O que fica claro nesse contexto é as angústias serem visíveis de todos os lados, alunos, pais e professores enfrentam suas próprias limitações, dificuldades em realidades diferentes, onde o centro da questão é a certeza de um ensino-aprendizagem de qualidade, que garanta nesse momento, pelo menos, o mínimo na transmissão dos conteúdos, e a absorção desses por parte dos alunos. Fica evidente também nas declarações, e na forma como está sendo o atual momento da educação no Brasil, já tão castigado, principalmente quando se fala em investimento nessa área, é que, com a Pandemia os prejuízos educacionais são certos e es- 
tão aí postos, não só na carga horária já prejudicada, mais no nível de aprendizagem que ficou sensivelmente prejudicada. As Secretarias, escolas e aos professores, coube inovar nas metodologias de modo a atenuar o que já se encontrava comprometido, a educação na sua forma mais legítima, quando falamos legítima, não nos referimos a legalidade na forma de ensinar, mais sim, com base nas respostas dos envolvidos nesse estudo, professores, alunos e pais. Nós reportamos ao ensino regular presencial, que nossos alunos perderam nesses quase dois anos de isolamento social, de março de 2020 até fins de 2021, sem aulas presenciais.

\section{Pai "professor adjunto"}

Nas pesquisas realizadas com cerca de $10 \%$ dos pais com filhos matriculados em uma escola pública nas séries iniciais do 1.0 ao 5.o do ensino fundamental 1, no municipal de Maracanaú-CE, 46,5\% dos pais afirmam que têm dificuldades para ensinar seus filhos, 40,7\% responderam às vezes, e somente $12,8 \%$ dizem não ter dificuldades para assumir a tarefa de acompanhar os ensinamentos dos filhos. Fica comprovado com os depoimentos, como é grande a quantidade de filhos sem o acompanhamento necessário na hora de realizar as atividades escolares no modo virtual no dia a dia, estamos falando aqui de crianças de 6 a 10 anos, de famílias carentes, de uma escola pública, localizada em um bairro altamente desprovido economicamente, social e cultural. São crianças que em sua grande maioria tem pais com um nível de escolaridade baixo, limitado ao ensino médio incompleto, que ainda não se fazem, ou podem estar presentes durante o dia, pois de $69,2 \%$ desses pais 
afirmam que trabalham fora, e só chegam em casa no final da tarde ou à noite, o que impossibilita o auxílio na educação dos filhos, mais diretamente nesse caso, na participação das aulas remotas e na execução das atividades diárias. É importante acrescentar, que mesmo assumindo que não tem tempo de assistir aos filhos no desenvolvimento das tarefas diárias, $70,7 \%$ dos pais acreditam que a escola está preparada para atender aos filhos na "modalidade" do ensino remoto, embora em sua grande maioria, sejam categóricos em afirmar que não veem seus filhos com uma evolução satisfatória, com esse novo método de ensinar, “... penso que não é a mesma coisa que presencial, porque às vezes não dão tempo de ensinar, ela porque chegou tarde e também penso que ela não se concentra tanto, não presta atenção, é muito diferente por que não sou professora, eu como mãe não consigo ensinar aos meus filhos”.

Além de suas próprias dificuldades em acompanhar os filhos nesse processo de ensino-aprendizagem como co-responsáveis, os pais citam várias situações, por seus filhos não estarem evoluindo nesse sistema de aulas virtuais. Enquanto uns desabavam que não ter tempo, outros colocam a culpa nos próprios filhos(as), “... ela está com dificuldade na aprendizagem, ela não aprendeu a ler ainda” “ É porque ele não quer fazer as tarefas, pois ainda tem dificuldade na leitura", outro diz: ele tem muitas dificuldades nas leituras e escritas, e observo algumas dificuldades às vezes”,“... ele tem preguiça de copiar do celular". E assim são diversas as queixas dos pais sobre a efetividade das aulas remotas, sua eficiência, principalmente quando se fala em resultados de uma educação de qualidade, e não quantidade. $\mathrm{O}$ que se percebe é que em grande parte das reclama- 
ções, e insatisfações, gira em torno do baixo nível de escolaridade dos alunos, respeitando aqui suas particularidades, em especial no tempo e permanência de acesso às aulas remotas, que não são regulares a todos os alunos. Vale lembrar ainda, que as respostas aqui retratadas, se referem aos pais de alunos do Ensino Fundamental 1, de 6 a 10 anos, como dito anteriormente, ou seja, crianças que ainda estão em processo de alfabetização, mais especificamente no caso do $11^{\circ}, 2.0$ e 3.0 anos. No entanto, com a situação da pandemia e o isolamento social imposto logo no início do ano de 2020, e consequentemente a suspensão das aulas, esse processo de alfabetização ficou ainda mais frágil, complexo, pois alfabetizar já não é uma tarefa fácil, simples, imagine alfabetizar através de aulas remotas, sem o devido acompanhamento da família(pais), e ainda em um contexto de "confinamento social". Nesse cenário o nível dos alunos do $1 .^{\circ}$ ao 5.o ensino fundamental 1 e consequentemente as demais séries de ensino, passados quase dois anos da pandemia, em eficiência e eficácia, não tiveram a devida evolução que certamente teriam no cotidiano das aulas presenciais, esse processo praticamente estagnou, em relação ao nível que os alunos se encontravam no início de 2020.

O sentimento predominante demonstrado pelos pais é de profunda tristeza e angústia, e muito expressivo, cerca $73 \%$ dos entrevistados afirmam não saberem ensinar, ou não ter tempo disponível para ficar ao lado dos filhos, quando estes não conseguem entender o que deve ser feito, ainda nas respostas obtidas em relação ao sentimento que eles nutrem, $27 \%$ se declaram felizes com o desempenho e aprendizado dos filhos. Existe um conflito de sentimentos, pois mesmo os pais afirmando 
que a escola está preparada, que os materiais oferecidos são suficientes e adequados para o bom desenvolvimento de seus filhos em casa, uma grande parcela deles dizem que se sentem felizes, e, em simultâneo, tristes e aflitos, um misto de emoções que traduz fielmente o momento que estamos passando com essa Pandemia. Talvez por estarem lhe dando com fatores imprevistos como as aulas remotas, que requer um apoio direto a seus filhos nesse processo, e vale lembrar que muitos são analfabetos digitais. Houve casos também de professores que tiveram grande dificuldades em lidar com essa "nova" ferramenta tecnológica, em manusear outras funções que o celular dispõe, e muitos nem sequer tinham essa habilidade, mas agora era necessário, importante e crucial para o desenrolar das aulas virtuais. Certamente este é mais um dos fatores que mais contribui para que muitos pais deixem de auxiliar seus filhos nos estudos, isso fica evidente, com a frequência com que os pais ligam para os professores, pedindo auxílio para poderem ajudar os filhos. Sem esse amparo, muitas crianças deixam de participar das atividades e isso fica comprovado com o alto índice de evasão ocorrido durante as aulas virtuais. Para que todos tenham êxito é necessária uma maior interação entre os entes envolvidos, escola e família, pois só assim os danos já causados, poderão ser reduzidos até que seja restaurado o ambiente regular de ensino, as salas de aulas, a escola.

\section{Conclusão}

Em suma, diante dos fatos observados nas pesquisas, realizadas com professores, pais e alunos, coordenadores e diretores de escolas, chega-se ao final deste 
artigo, com a certeza de que todos os envolvidos nesse "novo processo de ensino" precisam estar cientes do papel que cada um terá que desenvolver, o aluno precisa assumir sua condição de aluno, e saber que ele por ser o foco de todo processo educacional, deve estabelecer e manter suas rotinas de estudo como prioridade, e na "incapacidade" de realizar tais rotinas, cabe aos pais ou a família essa responsabilidade, de acompanhar, apoiar, cobrar e fazer com essas rotinas estabelecidas sejam de fato obedecidas diariamente. Não existe educação isolada, toda forma de educar é coletiva, mesmo quando estamos sós, em casa, nesse momento de aulas remotas, e isolamento social. O ensino é universal, e como tal precisa ser auxiliado, e nesse aspecto, os pais têm papel fundamental em apoiar mais diretamente seus filhos para estes sentirem-se estimulados.

No entanto, nesse contexto em que estamos descrevendo, percebemos diante das respostas obtidas, que existe pouca cooperação da família, por motivos diversos, desde a falta de tempo, até o nível intelectual dos próprios pais. Certamente para os alunos da rede pública é ainda mais difícil acompanhar as aulas remotas, em especial por que tratamos aqui de famílias carentes, em sua grande maioria semialfabetizados, e com pouquíssimos recursos financeiros. Diante de diversos aspectos negativos demonstrado na pesquisa, manter em plena funcionalidade as aulas remotas em especial na escola pública, chega a ser memorável, pelo esforço e dedicação de todos os que uniram forças na tentativa de manter a qualidade do ensino-aprendizagem em tempos de pandemia. Como bem disse uma mãe: "Faço o meu melhor para que ele não fique atrasado, mas não sou professora...”, ou seja, fica claro nesse 
depoimento, que dentro de suas possibilidades alguns pais estão fazendo o seu melhor, na hora de apoiar os filhos nas atividades remotas.

É importante deixar claro, que não estamos dando como concluído, como definitivo este estudo, é certo que muito ainda precisa ser feito, pesquisado e analisado, de modo a termos números mais expressivos, consistentes e reais, sobretudo em relação ao universo de alunos pesquisados, e regularmente matriculados nas escolas da rede pública municipal de Maracanaú, ponto de partida da pesquisa.

Portanto, em nossas considerações finais, queremos deixar aqui nesse primeiro momento, que apesar do universo pesquisado, cerca de $10 \%$ de pais, alunos e professores de uma única escola pública municipal de Maracanaú, a abordagem foi produtiva, pois podemos perceber alguns sentimentos das famílias diante do ensino remoto. Não queremos fixar falsas impressões, sejam essas positivas ou negativas. O importante é lembrar e perceber, que não só por conta da pandemia, mas os alunos de escolas públicas, são os que mais tem prejuízos em termos educacionais. "Segundo levantamento feito pela Secretaria Estadual da Educação de São Paulo (Seduc-SP). Os impactos da troca do ambiente escolar pelo virtual se demonstram ainda maiores para os alunos dos anos iniciais, especialmente os da rede pública... estudantes do 5.0 ano do ensino fundamental apresentaram os piores índices de queda na aprendizagem, na comparação com resultados do Saeb de 2019”. (Fonte: Agência Senado)

É imprescindível deixar claro, que durante a realização da pesquisa, não foi possível estabelecer um parâmetro de aprendizado de anos anteriores, com o 
atual ano letivo durante a pandemia, do nível de conhecimento dos alunos em relação às atividades $\mathrm{e}$ matérias que estão sendo trabalhadas com eles, seria necessário para isso a realização de um teste avaliativo sobre os conteúdos estudados nesse período, o que não é foco desse estudo. Certamente esse ponto em especial pode se tornar pauta de um estudo posterior. Portanto, como já mencionado, o ponto em questão era estabelecer uma conexão entre, o que os pais pensam e acreditam sobre o ensino remoto e seus resultados. Apesar de um universo pequeno de pesquisados, o resultado serve como base para estudos mais profundos, em relação à capacidade e compromisso dos pais no acompanhar as atividades dos filhos e principalmente o sentimento que nutrem diante "novo" momento do ensino remoto. Suas angústias, anseios, dificuldades, esperanças e os questionamentos apresentados sobre o desempenho e evolução dos filhos nas aulas virtuais. Sendo assim, acreditamos que o objetivo dentro proposto, foi consideravelmente atingido, apesar das dificuldades encontradas na pesquisa, em especial em relação ao número de pais e alunos que responderam aos questionários de modo virtual, já que o isolamento não permitia a pesquisa presencial. Mesmo assim, os percentuais demonstrados nas pesquisas revelam o sentimento dos envolvidos com essa nova metodologia de ensino, e deve servir como fonte de aprimoramento para novas ações que reduzam os prejuízos dos alunos da rede pública.

\section{Referências}

Organização Pan-Americana da Saúde e Organização Mundial da Saúde (OMS), Histórico da pandemia de 
COVID-19( https://www.paho.org/pt/covid19/historico-da-pandemia-covid-19).

Instituto Península - Relatório de pesquisa: Sentimento e Percepção ds Professores (https://www.institutopeninsula.org.br/wp-content/uploads/2020/05/Pulso-Covid-19).

Insper (Instituto de Ensino e Pesquisa) Reratos da Educação no Brasil- Paes, Ricardo de Barros,publicado na Folha de S. Paulo em 2017, 38 páginas.

Secretaria Estadual da Educação de São Paulo (Seduc-SP) - Saeb de 2019", Pademia acentua deficite Educacional.

(https://www12.senado.leg.br/noticias/infomaterias/2021/07). Fonte: Agência Senado. 


\title{
GESTÃO ESCOLAR DEMOCRÁTICA E PARTICIPATIVA: \\ DESAFIOS PARA GARANTIA DO CUMPRIMENTO \\ INTEGRAL DO ECA
}

\author{
Ana Maria Venancio da Silva \\ Helayne Vieira Correa Coêlho² \\ Maria Liduina Venancio Almeida 3 \\ Lore Ana Terceiro Persch ${ }^{4}$ \\ lury Torquato de Almeida ${ }^{5}$
}

\section{Introdução}

Os desafios para a gestão escolar só tendem a aumentar com o passar dos anos. É muito natural que os gestores encontrem dificuldades para se adaptar às mudanças. Quem diria que em pleno século XXI, uma pandemia iria atingir o mundo inteiro e caberia a co-

1 Graduada em Pedagogia - UECE; Especialista em Ensino de História - Faculdade Kurios; Especialista em Gestão e Coordenação Escolar - Faculdade Kurios; Professora do Município de Maracanaú/CE; E-mail: anamariavenancio3@gmail.com

2 Graduada em Pedagogia - UVA; Especialista em Ensino de Língua Portuguesa - UVA; Especialista em Gestão e Coordenação Escolar - Faculdade de Tecnologia Darcy Ribeiro; Especialista em Psicopedagogia - Faculdade de Tecnologia Darcy Ribeiro; Professora do Município de Maracanaú/CE; E-mail: helaynecorrea@hotmail.com

3 Graduada em licenciatura - UECE; Pós Graduada em Gestão Escolar e Coordenação Pedagógica - Faculdade Kirius;.

4 Lore Ana Terceiro Persch; Especialista em Gestão Escolar e Coordenação Pedagógica - kurios; Graduada em Pedagogia - UVA; Gestora do município de Maracanaú/CE; Professora do município de Maracanaú/CE; E-mail: lorepersch@gmail.com

5 Graduado em Administração - FAK; Licenciado em Pedagogia - FAK; Especialista em Gestão de Projetos - ABED; Especialista em Psicologia Organizacional e do Trabalho - FAK; Especialista em Gestão Escolar - FAESL; Especialista em Docência do Ensino Superior - FAK; Especialista em Gestão e Tutoria - UNIASSELVI; Mestre em Gestão de Negócios Turísticos - UECE; Doutor em Ciências da Educação - USC/PY; E-mail: iuryt.almeida@gmail.com 
munidade escolar se moldar às novas demandas que o cenário exige?

Verifica-se, portanto, que diante o contexto apresentado, a escola e a família não podem estar dissociadas, visto que uma depende da outra para alcançar o seu objetivo macro: o ensino-aprendizagem do educando, ou seja, precisam caminhar de forma conjunta para que o aluno aprenda, almeja um futuro promissor e possa colaborar na construção de uma sociedade mais justa, imparcial, igualitária e plural. Nesse contexto, Tiba (1996) cita que a escola precisa compreender ser uma instituição que tem, também, a função de complementar a família e que as duas instituições, tanto a familiar quanto a escolar, necessitam se apresentar como locais agradáveis e afetivos para os filhos que também são alunos. Assim, os pais e a escola devem apresentar princípios consonantes para o benefício desses educandos. Essa parceria, portanto, na visão de Tiba, incide em, primeiramente, uma instituição pôr-se no lugar da outra, e não somente no que se refere à troca de favores, entretanto, cooperando entre si, ou seja, buscando transmitir afetos, devem consentir escolhas e desejos, para que desse modo, o aluno/filho possa desenvolver-se de forma integral.

Existem alguns aspectos que precisam ser revistos nessa parceria. Um deles é a questão que muito preocupa os partícipes desse processo, inclusive os professores, gestores e a família do próprio aluno - trata-se da questão da não participação dos alunos no contexto das atividades não presenciais. Existem três fatores bastante robustos: o não acesso às tecnologias, a desestruturação familiar e o desinteresse do aluno/família. Grande parte dos alunos não conseguem participar 
desse novo cenário e/ou contexto, de um cotidiano escolar a distância gerando uma situação de desigualdade para quem já é desigual socialmente. Portanto, a escola tem a responsabilidade de se associar com a família, e os pais têm o direito a ter conhecimento da realidade enfrentada.

A princípio, faz-se necessária uma tomada de consciência de que as reuniões norteadas em temáticas teóricas e abstratas, empregadas para obter a atenção dos pais, a respeito da quantidade de problemas apresentados sobre os seus filhos - acerca das suas notas nas avaliações e trabalhos -, reuniões estas sendo bem extensas, sem planejamento adequado, em que só o professor e/ou coordenador opinam, não são aconselháveis e não proporcionam a abertura para o princípio de uma proposta de parceria, pois estes temas não interessam aos pais.

Vale ressaltar, aqui, o que consta no parágrafo único do Capítulo IV do Estatuto da Criança e do Adolescente - ECA (BRASIL, 1990), "é direito dos pais ou responsáveis ter ciência do processo pedagógico, bem como participar da definição das propostas educacionais". Nesse aspecto, é necessário conduzir as famílias ao convívio escolar, visto que o que se encontra prescrito no ECA, por conseguinte, falta ser colocado em prática.

A resposta destas e de outras dificuldades apresentadas que se tornam questões bastante atuais na educação, é encontrada nas próprias gerações. A geração dos avós educou seus filhos de forma patriarcal, com autoridade vertical. Por isso, os pais eram submetidos ao autoritarismo. A intenção destes pais subjugados pelos seus antecessores é a de não repetir a façanha dos seus pais. Assim, querem educar os seus filhos de 
maneira bem diferente do autoritarismo de outrora, entretanto, muitos são extremamente permissivos, aderindo à horizontalidade. A nova configuração familiar, ou seja, a geração atual, é a de mães sendo as mantenedoras das suas casas, criam seus filhos sozinhos, e, necessitam trabalhar fora para auxiliar no sustento familiar e, em muitas das vezes, é a única que garante a subsistência dos seus filhos. Inclusive, muitas se sentem culpadas por trabalhar fora de casa e deixar os seus filhos sozinhos ou com os filhos maiores, com a vizinha, tios, avós ou afins.

Nesse contexto, Ferreira (2018, p. 10-11) esclarece que.

Esses empecilhos devem ser objetos de reflexão pela família e pela escola, pois são circunstâncias que interferem na maneira com que ambas as partes se relacionam, dentro de uma dinâmica que precisa ser superada. Existe também a questão da falta de tempo, colocada como empecilho pelas famílias que, muitas vezes, afirmam que por razão dos empregos, não possuem tempo para comparecer às reuniões escolares dos seus filhos e nem participar das tarefas diárias, ficando a educação em segundo plano.

É fundamental pensar a função social da escola, considerando a função do gestor e da comunidade escolar nos vínculos de poder no caminho da gestão democrática.

A finalidade é que essa parceria se edifique por uma intervenção planejada e bem executada, em que a escola crie espaços de reflexão e experiências de vida em uma comunidade educativa, promovendo, assim, a aproximação entre as instituições familiar e escolar. A finalidade é clarificar a escola do seu papel na constru- 
ção dessa parceria: a intervenção pedagógica a essas questões tão atuais precisam ser concretizada no sentido de sopesar a necessidade da família em experienciar reflexões que lhes proporcionem a reconstrução da autoestima, para que se percebam, a princípio, compreendidos, e não acusados, recebidos e não desacolhidos, pela instituição escolar, para que, dessa forma, sintam-se reconhecidos e consolidados como parceiros nesta relação entre família e escola. Desse modo, é importante que a escola tenha uma cultura de prática ativa do estudante, provendo recursos e ferramentas que lhe dê a possibilidade e capacidade de conseguir resolver problemas, não sendo apenas um mero receptor de conhecimento.

Ademais, isso permite que o aluno aprenda de fato o conteúdo que lhe é transmitido, sinta-se seguro para colocar em prática todo o ensino que recebeu e recebe de seus educadores, com plena consciência de que consegue produzir, articular, analisar e desenvolver uma mentalidade crítica do mundo que o cerca.

Ao agir desse modo, a escola contribui para pleno desenvolvimento do aluno, ressalta, portanto, a sua importância para a sociedade, contribui efetivamente para a qualidade da educação e cumpre seu propósito de educar, ensinar e formar novos cidadãos prontos a atuar no mundo e dispostos a enfrentar os desafios que se apresentam na sociedade e, assim, desempenhar bem o seu papel de cidadão.

\section{Conclusão}

As reflexões apresentadas durante este trabalho sinalizaram a importância de estabelecer o clima de sa- 
tisfação, participação e integração de toda comunidade escolar, para adquirir resultados positivos aos preceitos legais e pedagógicos no ambiente escolar. Através de leitura com base nos autores citados e suas obras, confirma-se na literatura que o diretor é a peça chave para o processo democrático da gestão escolar, pois, nota-se na comunidade escolar a quantidade de especulações acerca da realidade, porém pouca percepção e certeza do real.

Por meio da participação familiar, facilita-se a relação dos alunos com os meios de aprendizagem, além de colaborar para a aquisição de valores como cumplicidade, afetividade, solidariedade, entre outros. No dia a dia profissional, nota-se como algumas famílias lidam com as dificuldades escolares de seus filhos, sobretudo, com o relacionamento destes com os professores e colegas. Assim, percebe-se, em muitas das vezes, a omissão dos pais em relação ao cotidiano escolar dos seus filhos. Faz-se necessário que a escola conheça as famílias dos alunos para mapear quantas e quais famílias podem apenas cumprem o seu dever legal, quantas e quais têm condições para um acompanhamento sistemático da escolarização dos filhos e quantas e quais podem, além de acompanhar os filhos, participar mais ativamente com a gestão escolar e, assim, apoiar outras crianças e famílias.

É nesse sentido que a interação com famílias se destaca como uma estratégia importante para o planejamento escolar e educacional. Sendo assim, é necessário que o diretor tenha a certeza de que a presença não se dá pela oportunidade, porém as ações positivas, sem dúvidas, contribuem de forma significativa na inovação e no apresentar de caminhos para o hábito de pensar, 
estudar e discutir de forma coletiva sobre a democratização escolar.

\section{Referências}

BRASIL. Estatuto da Criança e do Adolescente. Lei no 8069, de julho de 1990.

BRASIL. Lei de Diretrizes e Bases da Educação Nacional - Lei no 9.394/96, de 20 de dezembro de 1996. Diário Oficial da União, 23 de dezembro de 1996.

FERREIRA, Carla Hariele. Discutindo a relação família-escola na educação infantil: Reflexões a partir da perspectiva de mães. Trabalho de Conclusão de Curso (Graduação em Psicologia) - Universidade Federal de Uberlândia, 2018, p. 1 a 31. Disponível em: https://repositorio.ufu.br/handle/123456789/26124. Acesso em: 27/03/2021.

TIBA, I. Disciplina, limite na medida certa. 41. ed. São Paulo: Gente, 1996.

TIBA, I. Quem ama, educa. 2. ed. São Paulo: Gente, 2002. 


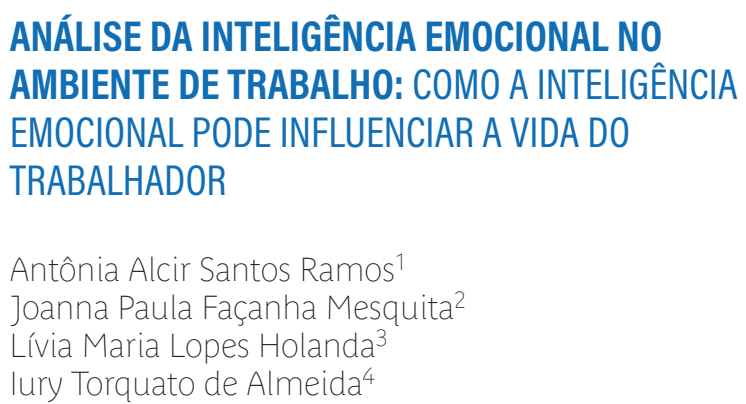

\section{Introdução}

A inteligência emocional foi um conceito proposto pelos psicólogos Peter Salovey e Jhon Mayer na década de 90 e atualmente sua definição refere-se "à capacidade de perceber acuradamente, de avaliar e de expressar emoções; a capacidade de perceber e/ou gerar sentimentos quando eles facilitam o pensamento; a ca-

1 Graduada em Pedagogia - UVA; Graduada em Matemática - UVA; Especialista em Gestão escolar e em Educação Especial - UVA; Professora do município de Maracanaú/CE; Professora do município de Maranguape/CE; E-mail: alcirramoslais@gmail.com

2 Graduada em Pedagogia - UVA; Especialista em Gestão Escolar Universidade São Luís; Professora da Prefeitura de Maracanaú-CE; E-mail: joannafacanhamesquita@gmail.com

3 Graduada em Lic. Plena em Pedagogia e Matemática - UVA, Especialista em Gestão Educacional e Escolar - INTA. Professora da rede municipal de Maracanaú. Atuante na área educacional desde de 1993 com experiência em Gestão Educacional, Gestão Escolar e Coordenação Pedagógica, em redes públicas e privadas, tendo atuação também nas séries iniciais e finais do ensino fundamental, médio no Ensino Superior; liviamarialhjr@gmail.com

4 Graduado em Administração - FAK; Licenciado em Pedagogia - FAK; Especialista em Gestão de Projetos - ABED; Especialista em Psicologia Organizacional e do Trabalho - FAK; Especialista em Gestão Escolar - FAESL; Especialista em Docência do Ensino Superior - FAK; Especialista em Gestão e Tutoria - UNIASSELVI; Mestre em Gestão de Negócios Turísticos - UECE; Doutor em Ciências da Educação - USC/PY; E-mail: iuryt.almeida@gmail.com 
pacidade de compreender a emoção e o conhecimento emocional; e a capacidade de controlar emoções para promover o crescimento emocional e o intelectual" (MAYER E SALOVEY, 1997).

A inteligência emocional ficou então definida em quatro aspectos ou áreas. A primeira área diz respeito à percepção, avaliação e expressão da emoção, que significa que as pessoas são capazes de identificar emoções em si e nos outros. A segunda área refere-se à emoção facilitando o ato de pensar, associando a influência das emoções na inteligência. Em alguns casos, a emoção pode dar preferência ao pensamento, quando necessário sua atenção para execuções de tarefas. A pessoa que tem uma inteligência emocional mais eficaz teria que conseguir entender suas mudanças de humor e se planejar de acordo com ele (MAYER, SALOVEY, CARUSO E SITARENIOS, 2001). A terceira é chamada compreensão de análise de emoções, que se refere à capacidade de rotular emoções, de decifrar os conceitos que elas trazem sobre os relacionamentos interpessoais. Por fim, a quarta área trata do controle reflexivo de emoções para promover o crescimento emocional e intelectual, em que se declara que um indivíduo deveria ser aberto às emoções quando elas sucederem, sejam agradáveis ou desagradáveis, controlando a emoção tanto em si como nos outros, refreando ou evitando emoções negativas e valorizando as agradáveis (MAYER E SALOVEY, 1997).

Quando se trata de ambiente de trabalho percebe-se que nas organizações as emoções podem interferir nas mudanças dos planos estratégicos, mesmo que estes estejam alicerçados em princípios de racionalidade, como metas, estratégias, objetivos e tantos outros, com a finalidade de cumprir seus propósitos na empresa. As 
emoções fazem parte do ambiente de trabalho e podem mostrar-se de formas agradáveis e positivas bem como desagradáveis e negativas, como exemplos tem-se a altivez ao ganhar uma promoção, ciúme pela conquista do colega de trabalho, raiva ou desânimo por não alcançar uma meta, euforia por um projeto novo (CHERNISS \& GOLEMAN, 1998). O desenvolvimento do coeficiente emocional, sendo um parâmetro usado para mensurar o nível de inteligência emocional, está associado com a capacidade de lidar com mudanças na rotina e ter controle emocional a respeito das emoções e sentimentos e tem se tornado cada vez mais importante para o sucesso e sobrevivência da organização. $O$ interesse das empresas pela inteligência emocional pode estar associado a uma hipótese de que os profissionais com maior controle sobre suas emoções são provavelmente os mais bem sucedidos no mercado de trabalho e também têm uma melhor qualidade de vida (ROBERTS, FLORES-MENDOZA E NASCIMENTO, 2002).

Sendo assim, o objetivo deste trabalho é desenvolver uma pesquisa teórica de natureza bibliográfica para analisar o uso da inteligência emocional no ambiente de trabalho e também em como ela contribui para as relações interpessoais, bem como a capacidade do indivíduo de controlar suas emoções em busca de se ter crescimento intelectual e emocional no ambiente de trabalho.

A realização da pesquisa justifica-se em compreender como a inteligência emocional pode influenciar no desempenho do indivíduo em seu ambiente de trabalho para que ele se torne um profissional bem-sucedido. 


\section{Inteligência emocional no ambiente de trabalho}

A inteligência emocional é meramente a utilização da inteligência das emoções, ou seja, é fazer propositadamente com que suas emoções trabalhem a seu favor, usando-as como ajuda para impor o aperfeiçoamento de seus resultados por meio do seu comportamento e raciocínio (WEISINGER, 2001).

É incontável a quantidade de episódios e situações em que a inteligência emocional pode ser posta em prática no ambiente de trabalho e ela pode ser usada tanto pelo próprio profissional quanto em relações interpessoais. As emoções têm um papel bastante importante no local de trabalho, pois o indivíduo diariamente encontra-se em novas situações nas quais é necessário utilizar as emoções de forma inteligente para orientá-lo em seu comportamento e raciocínio de modo a alcançar melhores resultados. Desta forma, a prática da inteligência emocional no ambiente de trabalho leva o profissional a ter resultados positivos, tanto para ele mesmo quanto para a organização. Logo, torna-se fundamental aprender a usar algumas técnicas que integram a inteligência emocional, entre elas, destaco neste trabalho, a autoconsciência, o controle emocional e a motivação (GUEBUR, POLETTO e VIEIRA, 2007).

Inicialmente abordar-se-á neste artigo sobre a autoconsciência que é a base em que são construídas as características da inteligência emocional e a partir dela é possível controlar-se, proporcionando que as próprias ações funcionem em seu benefício. Quando o profissional tem consciência de seus sentimentos e suas atitudes isso pode ajudá-lo a ter uma melhor compreensão das situações que se apresentam em sua rotina de tra- 
balho colaborando na forma de agir, reagir, comunicar e intervir de forma racional em diferentes situações, ou seja, ter autoconsciência significa verificar as informações antes de tomar qualquer atitude. Sendo a autoconsciência um elemento básico da inteligência emocional, quando se aprende a controlar as emoções e a motivar-se, torna-se possível expandi-la. A inteligência emocional entra em ação quando as informações chegam ao sistema perceptivo, isso significa, que só é possível ao indivíduo controlar a raiva, por exemplo, ao ter consciência do que a provoca. Outro exemplo é o desânimo, para não o deixar dominar e conseguir ter motivação, é necessário ter consciência do modo com que as afirmações negativas o influenciam e, prejudicam seu desenvolvimento no trabalho. $\mathrm{E}$ para isso é necessário fazer uma autoanálise, de modo a compreender o que o leva a agir de tal forma, controlando-se antes de mudar de comportamento em busca de se obter melhores resultados. Um baixo nível de autoconsciência pode prejudicar o desempenho das tarefas, por não disponibilizar informações necessárias para tomada de decisões eficientes, o que podem causar danos no trato com as pessoas e com situações em que se apresentam e para evitar isto é necessário aprender a prestar atenção nos sentidos para assim conseguir examinar, esclarecer e alterar suas opiniões sempre que foram necessários (WEISINGER, 2001).

Outra técnica importante é o controle emocional. As emoções são feitas por uma interação de pensamentos ou avaliações cognitivas, alterações fisiológicas e atitude ou tendência de ação. É possível controlar as emoções monitorando esses componentes. Quando o indivíduo compreende que os pensamentos são altera- 
ções físicas e atitudes que comandam as reações emocionais, fica possível reconhecer que o poder de controlar qualquer emoção pertence a ele mesmo e não a outra pessoa e isso fará com que ele esteja no controle. As situações perturbadoras tendem a gerar estilos e padrões de raciocínio distorcidos que mudam sua percepção da realidade, e podem ser elas, uma repreensão do chefe ou estar chateado com um colega de trabalho. Quando se aprende a evitar o raciocínio distorcido se tem melhores condições de conseguir maior controle sobre os pensamentos automáticos e as emoções. Esses pensamentos automáticos são espontâneos e frequentemente produz um resultado oposto do esperado, em contrapartida, os diálogos internos são construtivos, pois ajudam a desfazer os efeitos negativos de tais pensamentos. Isto é, diante de uma situação emocionalmente desgastante é importante ter um diálogo interno e buscar fazer uma avaliação do contexto, presumindo que emoções acarretaria e fazendo anotações das informações positivas. Com isso, seria possível controlar as emoções de forma eficaz e também estaria apto para lidar com a situação de forma emocionalmente inteligente. É preciso aprender a observar as próprias ações e a desenvolver a capacidade de usar a inteligência emocional, para fazer com que as emoções ajam a seu favor. Dessa forma, o controle das emoções é um elemento fundamental nas relações pessoais e também profissionais, visto que reduz o estresse e aumenta a eficiência (WEISINGER, 2001).

Diante desse cenário, entra a motivação como um fator fundamental para alcançar os objetivos pessoais e melhorar a eficiência profissional. A motivação é uma característica muito apreciada nas organizações, pois quando o funcionário está motivado ele é mais esfor- 
çado e tem menos períodos de baixa produtividade. $\mathrm{Na}$ inteligência emocional a motivação tem o significado de usar a energia necessária para um objetivo específico e mantendo sua evolução até atingir o objetivo desejado. Existem formas de manter ou recuperar a motivação, antes de tudo é preciso que o indivíduo busque a motivação em si mesmo, esforçando-se para reforçar o otimismo com afirmações motivadoras. Também é importante no processo de motivação ter uma autocrítica construtiva e traçar metas, pois elas estimulam e mantém o indivíduo em direção ao seu objetivo. É importante que o local de trabalho disponha de um ambiente saudável e estimulante. Recomenda-se que tenha uma boa ventilação, iluminação e sons agradáveis, pois estes também podem afetar a motivação. São muitos os motivos que interferem de forma negativa ou positiva no desempenho das atividades em uma organização, por isso, é importante que haja uma organização do local de trabalho para que ajude no desempenho das funções de forma produtiva (WEISINGER, 2001).

Outro elemento de grande importância no ambiente de trabalho, e que é a base de qualquer relacionamento, é a comunicação. Quando se usa a inteligência emocional para a comunicação, nota-se o que se está sendo comunicado, por meio dos pensamentos, sentimentos e atitudes dos demais, assim, convém adequar-lhes a comunicação de maneira que a sensibilidade passe a ser uma técnica. Sendo assim, faz-se necessário desenvolver técnicas de comunicação para que situações conflitantes sejam solucionadas de forma positiva. São elas a auto revelação (revelar o que se pensa, sente e deseja); a positividade (defender as opiniões, ideias, crenças e necessidades próprias e, em simultâneo, respeitar as 
dos outros); a escuta dinâmica (ouvir o que o outro está dizendo); a crítica (expor construtivamente as ideias e sentimentos em relação a ideias e atos de outros); a comunicação de equipe (saber comunicar-se em uma situação de grupo). As técnicas de comunicação são fundamentais para a inteligência emocional do indivíduo e elas têm valor incalculável no ambiente de trabalho. Pôr em prática os conceitos da inteligência emocional nas relações profissionais faz com que se tenha um aumento da satisfação do profissional e de sua eficiência no desenvolvimento de suas atividades (WEISINGER, 2001).

Diante disso, profissionais com habilidades em sua inteligência emocional podem aumentar a qualidade de suas relações com colegas de trabalho e também aumentar a confiança em suas técnicas emocionais, como interagir mais efetivamente com os outros. A inteligência emocional pode ajudar no desempenho do profissional, e isso pode refletir no aumento de salário e no grau de relacionamentos com outros funcionários, habilitando-o na criação de relações efetivas, a trabalharem de forma positiva em times e também pode contribuir para o desempenho do profissional em seu ambiente de trabalho permitindo que ele possa regular suas emoções para o controle efetivo da tensão, e assim executar suas tarefas mesmo sob pressão, ajustando-se as mudanças organizacionais satisfatoriamente (LOPES et al, 2004).

Em tempos atuais em que se tem um avanço na tecnologia, é necessário desenvolver o amadurecimento da cognição humana. Logo, é de grande importância aprender a usar a inteligência emocional para haver empatia nos relacionamentos e para pôr em prática habilidades necessárias para um bom desempenho de suas atividades (GUEBUR, POLETTO e VIEIRA, 2007). 


\section{Conclusão}

O conteúdo abordado neste trabalho teve como objetivo analisar e contribuir para o conhecimento sobre como a inteligência emocional pode influenciar no desempenho do indivíduo em seu ambiente de trabalho para que ele se torne um profissional bem-sucedido.

Os indivíduos que aprendem a desenvolver a inteligência emocional tende a aprimorar suas concepções e ideias assumindo o controle de suas emoções, não deixando elas dominarem e assumirem o controle da situação, o que poderia acarretar um resultado oposto do que se espera de um bom profissional, e com isso o indivíduo tem uma maior probabilidade de alcançar sucesso em sua carreira.

A inteligência emocional permite que o profissional tenha habilidade para o trabalho em equipe, possibilitando que ele tenha equilíbrio consigo mesmo e com os outros, tornando-o mais eficiente e cooperativo. As emoções têm grande influência no local de trabalho, pois o profissional diariamente encontra-se em diferentes situações nas quais é necessário utilizar as emoções de forma inteligente para orientá-lo em seu comportamento de modo a alcançar melhores resultados.

Desta forma, a prática da inteligência emocional no ambiente de trabalho leva o profissional a ter resultados positivos, tanto para ele mesmo quanto para a organização. Para se ter um bom desempenho no ambiente de trabalho e também ter uma melhor qualidade de vida é necessário, primeiramente, conhecer-se a si mesmo, para ser possível entender o outro e assim se possa ter uma maior comunicação com as pessoas do grupo, tendo paciência para escutar e saber responder 
no momento adequado, buscando agir com tranquilidade, proporcionando um ambiente em que o trabalho possa ser desempenhado com qualidade.

\section{Referências}

CHERNISS, C; GOLEMAN, D. (1998) Bringing emotional intelligence to the woekplace. Consortium for research on Emotional Intelligence in Organizations, October.

GUEBUR, Andréa Z.; POLETTO, Cleusa A.; VIEIRA, Daicy M. S. (2007). Inteligência emocional no trabalho. Revista Intersaberes, Curitiba, ano 2, n. 3, p. 71 - 96.

LOPES, P. N.; BRACKETT, M. A; NEZLEK, J. B.; SCHUTZ, A.; SELLIN, I.; SALOVEY, P. (2004). Emotional intelligence and social interaction. Journal of Personality and Social Psychology, v.30, n.8, p. 1018-1034.

Mayer, J. D., \& Salovey, P. (1997). What is emotional intelligence. P. Salovey \& D. J. Sluyter (Eds.), Emotional Development and Emotional Intelligence: Implications for Educators (pp. 3-31). New York: Basic Books.

Mayer, J. D., Salovey, P., Caruso, D. R. \& Sitarenios, G. (2001). Emotional Intelligence as a Standard Intelligence. Emotion, 1(3), 232-242.

Roberts, R. D.; Flores-Mendoza, C. E., \& Nascimento, E. (2002). Inteligência Emocional: Um Construto Científico. Cadernos de Psicologia e Educação Paidéia, 12 (23), 77-92.

WEISINGER, H. (2001). Inteligência emocional no trabalho: como aplicar os conceitos revolucionários da I. E. nas suas relações profissionais, reduzindo o estresse, aumentando sua satisfação, eficiência e competitividade. Rio de Janeiro: Objetiva. 


\section{RELATOS DE EXPERIÊNCIA DA PANDEMIA: VIVÊNCIAS DE UMA ESCOLA HUMANIZADA \\ Francisca Edirene de Sousa Mourão \\ Francica Luzia da Silva Martins² \\ Priscila Holanda Nogueira ${ }^{3}$ \\ Iury Torquato de Almeida ${ }^{4}$}

\section{Introdução}

Vivemos atualmente em uma sociedade contemporânea marcada pela violência, disputa pelo poder territorial por facções, causando muita instabilidade social e econômica principalmente das populações mais carentes e vulneráveis.

Além de tudo isso o mundo vem enfrentando, dede o final de 2019 grandes mudanças ocasionadas pela pandemia do Vírus COVID 19, muitas foram as perdas. A cada dia o número de casos de contaminação e de mortes, só aumentava uma das medidas de enfrentamento à propagação do vírus, orientação essa proveniente da

1 Especialista em Terapia Familiar/ UFC, Gestão Escolar /FMB, graduada em Pedagogia /UVA; Professora efetiva da Prefeitura de Maracanaú

2 Graduada em Pedagogia - UVA; Especialista em Administração Escolar, Supervisão e Orientação. Universidade CÂndido Mendes.; Secretária Escolar do município de Maracanaú/CE; E-mail: luzia367@gmail.com

3 Especialista em Gestão e Coordenação Pedagógica - FMB; Graduada em Pedagogia - FAK/UFC; Professora do município de Maracanaú/CE; E-mail: priscilaholanda7@gmail.com

4 Graduado em Administração - FAK; Licenciado em Pedagogia - FAK; Especialista em Gestão de Projetos - ABED; Especialista em Psicologia Organizacional e do Trabalho - FAK; Especialista em Gestão Escolar - FAESL; Especialista em Docência do Ensino Superior - FAK; Especialista em Gestão e Tutoria - UNIASSELVI; Mestre em Gestão de Negócios Turísticos - UECE; Doutor em Ciências da Educação - USC/PY; E-mail: iuryt.almeida@gmail.com 
OMS (Organização Mundial da Saúde) foi o distanciamento social, medida esta, desacata pela mesma entidade, como primordial para atenuar a propagação da mesma. Tal estratégia levou ao fechamento de escolas e universidades, a proibição de eventos de massa e de aglomerações, a restrição de viagens e transportes públicos, a conscientização da população para que permaneça em casa, até a completa proibição da circulação nas ruas, exceto para a compra de alimentos e medicamentos ou a busca de assistência à saúde. Essas medidas têm sido implementadas de modo gradual e distinto nos diferentes países, com maior ou menor intensidade.

No Brasil, imensas são as desigualdades sociais, mais da metade da população enquadra-se na situação de pobres e extremamente pobres, e apenas $40 \%$ da população está ocupada formalmente. Tais dados nos reflete a necessidade de medidas econômicas urgentes para a garantia de renda mínima aos mais vulneráveis e de proteção ao trabalho dos assalariados, de modo a garantir a adesão de uma relevante parcela da população às medidas de distanciamento social.

O objetivo deste estudo foi analisar o impacto positivo de uma escola humanizada frente as das políticas de distanciamento social na pandemia de COVID-19 e os desafios para sua implementação, de forma a ampliar a compreensão da necessidade de uma escola atuante na comunidade, por parte da população, dos docentes e dos órgãos que a regulam.

\section{Desenvolvimento}

A sociedade contemporânea exige um redimensionamento do olhar para as práticas educativas. Nes- 
se cenário, não se enquadra a educação fragmentada, o momento é de promover o diálogo e a ação interdisciplinar. Logo, é preciso perceber e proporcionar a interligação dos saberes, produzir e disseminar conhecimentos, conscientizando os sujeitos da necessidade de serem os protagonistas da sociedade. Além disso, é necessário redesenhar nossa educação para ir ao encontro das necessidades do futuro, a fim de prover aos alunos as competências para uma ação responsável, comprometida numa atmosfera solidária e colaborativa no universo social. Conforme Morin (2000, p.76).

Morin apresenta um desafio à educação quando fala em necessidades do futuro, cabendo à escola formar sujeitos capazes de saber viver num futuro incerto, com profissões ainda desconhecidas e com necessidades e interesses que se modificam constantemente. Nesse cenário, precisamos formar sujeitos capazes de lidar com a fluidez da atual sociedade. Mudanças serão constantes, por isso a necessidade de investir na capacitação de um sujeito crítico, criativo e consciente que saiba lidar com as emoções e com as pessoas, conforme o documento da Base Nacional Comum Curricular que enfatiza as habilidades socioemocionais, entre as cognitivas e de cunho comunicativo.

A educação atual, que prioriza a educação integral do ser e prima por um desenvolvimento em todos os aspectos, torna-se cada vez mais necessária, frente ao cenário vivenciado. Ao nos depararmos com o ensino à distância, foi necessário uma utilização emergencial de tecnologias remotas para o mantimento das aulas. Contudo muitos foram os prejuízos acarretados, frente a realidade de miséria existente no nosso País. 
Embora o fechamento das escolas possa ter o benefício adicional de contribuir para manter os pais em casa, esse efeito tende a dificultar o desenvolvimento dos alunos, a atuação do professor e por conseguinte a aprendizagem. Além disso, outros efeitos negativos seriam o aumento do número de crianças cuidadas pelos avós idosos, ou até mesmo nas ruas sem nenhum cuidado, a interrupção de programas gratuitos de merenda escolar para crianças vulneráveis e, evidentemente, os meses que as crianças ficariam sem educação formal.

Objetivou-se nesta pesquisa, analisar a experiência de uma escola da rede municipal de Maracanaú, com a oferta de ensino remoto durante a pandemia da COVID-19. A metodologia aplicada foi uma pesquisa descritiva e exploratória. Utilizamos um relato de experiência buscando descrever as vivência da escola que suscitou reflexões novas sobre a importância de uma escola humanizada, principalmente em períodos pandêmicos, tendo as pesquisadoras como sujeitos da pesquisa, que observou e relatou as experiências vivenciadas pela equipe escolar de uma escola pública que localiza-se próximo ao aterro sanitário do município e atende aos moradores que tiram seu sustento deste ambiente, através do trabalho de captação de resíduos, são pessoas humildes e desassistidas pelo poder público, tendo a escola como único equipamento presente e atuante na melhoria de vida dos mesmos. Segundo Saviane é "preciso compreender a própria finalidade da educação, colocando-a a serviço das forças emergentes da sociedade" (SAVIANI, 1989, p.23).

A pandemia por COVID 19, tornou mais evidente as dificuldades vivenciadas na escola, que propõe um plano de trabalho para amenizar a o impacto da pobre- 
za dentro do contexto de sala de aula. Pois acredita-se que com fome, sono e outras necessidades fisiológicas desassistidas dificulta-se ainda mais desenvolvimento cognitivo, físico, social e emocional das crianças. O trabalho da escola está vinculado diretamente à realidade social, econômica, cultural e política, na qual o docente e os alunos integram (LIBÂNEO,1994). A escola tendo como sua missão desenvolver habilidades na vida acadêmica inquietou-se com a realidade dos alunos, familiares, membros da comunidade, que sobrevivem da catação de resíduos no lixão. Ambiente esse insalubre, onde realmente prevalece a disputa pela sobrevivência. Com sensibilidade e empatia a escola buscou meios para garantir o mínimo de dignidade para todos, através de ações pedagógicas, culturais e sociais. Parte dessas ações, tornam-se possíveis devido um sistema de parcerias criado pela escola entre diversos órgãos públicos, entidades beneficentes, pessoas físicas e pessoas jurídicas.

A escola sofreu alterações em diversos aspectos desde a sua fundação, de um Centro e lavanderia comunitários para uma escola com adaptações físicas bem conservadas pela comunidade essas alterações foram de ordem física, estrutural e relacional por meio de recursos provenientes do PAE, bem como também por meio de ações que vem sendo desenvolvidas desde 2012 para que os moradores se empoderem com pertencimento, tornando-se responsáveis pelo processo e sucesso da escola e consequentemente da comunidade local. A partir das necessidades detectadas foi lançada a projeção da mesma ser escola de educação básica em tempo integral na busca de ampliar a jornada escolar e a permanência do aluno na escola. Após alguns ajustes 
a escola iniciou seu funcionamento em tempo integral em janeiro de 2020.

O primeiro projeto criado e desenvolvido na escola foi o Arte e Identidade que tem como objetivo principal o fortalecimento das relações interpessoais, elevar a autoestima e fortalecer a equipe para participação nos demais projetos e ações desenvolvidas na escola. No referido projeto foram realizadas reuniões para planejamento das ações, solicitação de demandas e verificação de materiais e pessoas disponíveis, a partir de então, parceiros foram solicitados, onde os mesmos realizaram capacitações por meio das artes, da música e das relações interpessoais. $O$ sucesso alcançado neste projeto nos permitiu a realização de vários outros projetos, a maioria deles criados e implantados no contexto da escola refletindo na comunidade, onde os profissionais da escola após as ações desenvolvidas pela escola, sentiram suas ideias valorizadas e apoiadas pela gestão, tornando-se assim, possível muitos dos demais projetos realizados. Desde então, a escola, a cada ano e a cada ideia acolhida, vem ampliando seus projetos e suas áreas de atuação.

Hoje, em meio a essa realidade de pandemia, temos tentado adequar os projetos a essa nova versão remota de funcionamento tanto para as atividades regulares quanto paras as atividades formativas do tempo integral, obedecendo a todos os protocolos de segurança, incentivando a formação de novos hábitos que garantam a segurança de todos. Atualmente devido o distanciamento social, exigido como medida de enfrentamento ao coronavírus, a escola exerce na comunidade além de suas funções específicas, a mesma desenvolve o atendimento de algumas necessidades bá- 
sicas de nossos estudantes, que encontram na mesma, cuidados com saúde, higiene e amenização da fome. A escola Irmã Dulce tem procurado manter o contato máximo com os nossos alunos, foram criados grupos de WhatsApp por turma onde diariamente os professores interagem com as crianças, infelizmente devido às condições sociais e econômicas muitas delas são privados da possibilidade de acesso às aulas remotas (atividades não presenciais). Cerca de $35 \%$ dos nossos alunos matriculados encontram-se off-line, recebendo atividades impressas na escola, número que só aumenta com o decorrer do tempo, onde se faz necessário a troca dos equipamentos tecnológicos utilizados pelas crianças por alimentos.

A escola continua por meio de suas parcerias fazendo doações semanais de leite e sempre que possível doações de alimentos, chips, objetos utilitários, roupas e calçados, medicamentos, sendo também veículo de distribuição, quando procurada por entidades locais e/ ou externas, na tentativa de amenizar os efeitos causados pela atual pandemia.

Carbonell (2001), defende a formação colaborativa como maneira de mudar a escola. Segundo ele, a cultura colaborativa que inicia-se na escola, mas deve avançar, formar "redes que se transformam em coletivos de renovação pedagógica que pensem e avancem em direção a uma escola diferente junto com outros movimentos sociais; a única maneira de mudar a escola" (CARBONELL, 2001, p.112)

\section{Conclusão}

A partir das pesquisas realizadas no contexto da comunidade escolar, ficou notório que dentre as princi- 
pais dificuldades pedagógicas, a migração pendular, as diversas idas e vindas durante o ano letivo, onde o mesmo aluno chega a ser matriculado e transferido inúmeras vezes dentro do mesmo ano letivo, impossibilitando a continuidade nas ações educativas, fator esse ocasionado pela violência local e pela disputa territorial por gangues e facções. Temos também, como fatores agravantes a fome e a violência doméstica, onde muitas de nossas crianças não dormem e nem se alimentam em suas residências, encontrando apenas na escola, abrigo seguro para manutenção dessas necessidades básicas e com a pandemia COVID 19 que acentuou ainda mais o estado de miséria da comunidade local, tornou-se necessário essa atuação humanizada por parte de toda a comunidade escolar, na tentativas de atenuar os efeito da pandemia sobre a aprendizagem e os envolvidos nela.

Um dos resultados alcançados com esse trabalho humanizado foi o envolvimento de toda a comunidade escolar e seu respectivo sucesso. Assim, quando a voz da comunidade tornou-se fundamental, a partilha de decisões e a influência dos pais deram grande suporte aos objetivos a serem alcançados e ainda favoreceu o processo de aprendizagem. Essa participação, oferecida pela EMEIEF Irmã Dulce tem possibilitado o desenvolvimento da comunidade, fortalecendo os laços, as relações e as reações necessárias à cultura cotidiana em comunidade, promovendo o pluralismo no respeito, exercícios de cidadania, comprometimento de todos, bem como senso de pertencimento ao processo educativo e sucesso no mesmo. Diminuindo o número de evadidos e reprovados, elevando suas notas em avaliações externas e conseguindo promover uma educação 
para vida com conceitos e valores essenciais aos seres humanos.

A escola vem crescendo em todos os aspectos, sendo uma referência de parceria e transformação para a comunidade local e vizinhança. Conta com uma boa fama conquistada com esforços coletivos, disciplina e crença que a Educação é transformadora, que liberta e torna feliz os que a possuem.

\section{Referências}

Conforme Norma ABNT. Disponível em: https://www. caedjus.com/wp-content/uploads/2019/07/Regras_ ABNT.pdf. Acesso em: 10 de junho de 2021.

Instituto Brasileiro de Geografia, Estatística (IBGE). Síntese de indicadores sociais: uma análise das condições de vida da população brasileira. Rio de Janeiro: IBGE; 2018

de Oliveira Lopes, Marcos Venícios SOBRE ESTUDOS DE CASOS E RELATOS DE EXPERIÊNCIAS ... Revista da Rede de Enfermagem do Nordeste, vol. 13, núm. 4, 2012 Universidade Federal do Ceará Fortaleza, Brasil

CARBONELL, J. A aventura de inovar. Porto Alegre: Artmed, 2001.

Câmara Monteiro, Edna. EDUCAÇÃO NA PANDEMIA: A EXPERIÊNCIA DE UMA ESCOLA DA REDE MUNICIPAL DE ENSINO DE CAMPINA GRANDE(PB). VII Congresso Nacional de Educação, 2020, Maceió

LIBÂNEO, J. C. Didática. São Paulo: Cortez, 1994, 263 p. (Coleção magistério. Série formação do professor).

SAVIANI, D. A filosofia da educação e o problema da inovação em educação. In: GARCIA, W. E. (org). Inovação educacional no Brasil: problemas e perspectivas. São Paulo: Cortez, p. 15-29, 1989. 


\section{O DESENVOLVIMENTO DA INTELIGÊNCIA}

EMOCIONAL NA EDUCAÇÃO INFANTIL: UMA

CONSTRUÇÃO POSSÍVEL NO ENSINO REMOTO

Maria Leidiane de Sousa Leite ${ }^{1}$

Moacir Rodrigues da Silva ${ }^{2}$

Walcineide Viana Barbosa ${ }^{3}$

lury Torquato de Almeida ${ }^{4}$

\section{Introdução}

O conceito de inteligência emocional ganhou espaço no cenário mundial na década de $1990 \mathrm{com}$ a publicação do artigo de Peter Salovey e John D. Mayer e de uma forma considerável em 1995, com os estudos de Daniel Goleman intitulado inteligência emocional.

Atualmente o tema é considerado a "competência do século" devendo estar inserido em todos os ambientes sociais, sobretudo da educação escolar, em todas as suas etapas de ensino, oportunizando uma melhor compreensão da importância da inteligência emocio-

1 Graduada em Pedagogia - UVA; Especialista em Lígua Portuguesa e Literatura Brasileira - UFC; Administração Escolar - UVA; Professora do município de Maracanaú/CE; E-mail: leidianeleite13@gmail.com

2 Especialista em Gestão Escolar - UDESC; Graduado em Pedagogia - UVA; Graduado em História e Geografia - UVA; Gestor do município de Maracanaú/CE; E-mail: mocirodrigues2808@gmail.com

3 Especialista em Avaliação e Planejamento do Ensino e Aprendizagem - UFC Graduada em Pedagogia - UVA; Coordenadora escolar do Município de Maracanaú/CE;

E-mail:Walcineide.vb@gmail.com

4 Graduado em Administração - FAK; Licenciado em Pedagogia - FAK; Especialista em Gestão de Projetos - ABED; Especialista em Psicologia Organizacional e do Trabalho - FAK; Especialista em Gestão Escolar - FAESL; Especialista em Docência do Ensino Superior - FAK; Especialista em Gestão e Tutoria - UNIASSELVI; Mestre em Gestão de Negócios Turísticos - UECE; Doutor em Ciências da Educação - USC/PY; E-mail: iuryt.almeida@gmail.com 
nal como fator favorável ao desenvolvimento integral dos educandos.

Este capítulo além de tratar do desenvolvimento da inteligência emocional na educação infantil, visa disseminar praticas pedagógicas que possibilitaram mesmo em tempos remotos, a realização de momentos de interação e ludicidade para o despertar das emoções por parte das crianças.

Inicialmente, será apresentado um breve percurso da inteligência emocional no século $\mathrm{XX}$, bem como alguns conceitos de inteligência emocional necessários para entendimento do tema. Em seguida, trataremos da particularidade da etapa da educação infantil na perspectiva das contribuições das emoções no desenvolvimento integral das crianças, à luz dos documentos educacionais oficiais para esta etapa de ensino.

Posteriormente, apresentamos vivências emocionais exitosas, em tempos remotos, observadas na EMEIEF Francisco Antônio Fontenele e na EMEIEF Governador César Cals de Oliveira Filho, que ao longo do período pandêmico colaboraram de forma significativa no desenvolvimento emocional das crianças.

Fechamos com as considerações finais, onde discorremos sobre questões pertinentes a partir dos relatos das vivências emocionais do trabalho.

\section{Inteligência emocional: percurso, conceitos e desenvolvimento}

Tendo em vista a compreensão do tema que nos propomos trabalhar, iniciaremos nosso estudo apresentando um breve percurso da inteligência emocional no século XX, seus conceitos e estudos acerca do desenvolvimento da mente emocional. 
O estudo acadêmico das emoções humana remonta ao século XX, com um extenso número de trabalhos, explorado sobretudo no campo da psicologia, como exemplos podemos citar os trabalhos de Eduard Thorndike (1920) "Administrar as emoções para agir de forma sensata nas relações humanas”, David Wechsler (1940) com o trabalho "Outros fatores além da habilidade intelectual estão envolvidos em comportamentos inteligentes", Abrahn Maslow(1950) com o estudo "Construir força emocional”, Howard Gardner (1980) com o importante estudo: "Estruturas da mentes - Teoria das inteligências múltiplas", Wayne Payne (1985) "Desenvolvendo a inteligência emocional".

$O$ percurso dos estudos referente às emoções $\mathrm{e}$ seus desdobramentos, mostram que os impactos das reações emocionais se constituíram como foco de pesquisas ao longo do século XX, contudo somente na década de 1990, ganhou reconhecimento ao nível mundial, impulsionado pelos trabalhos de Peter Salovey e Jonh D. Mayer (1990), chegando ao seu "auge" com os estudos do psicólogo Daniel Goleman (1995), inteligência emocional.

Segundo Salovey e Mayer (1990), emoções são definidas como respostas a acontecimentos internos ou externos e podem ser positivas ou negativas. Nesse viés, para a manutenção ou alcance do bem-estar é necessário o desenvolvimento da inteligência emocional, compreendendo-a como a capacidade de perceber e expressar a emoção, assimilá-la em si e nos outros. Entendemos assim, que para ser emocionalmente inteligente deve o sujeito estabeleça relações entre seus pensamentos e emoções, conhecendo e exercendo o autocontrole sobre as reações provocadas pelas emoções, 
reações do próprio sujeito bem como, dos demais atores envolvidos no processo interativo.

Ainda segundo os autores apud Goleman (2012, p. 66 e 67) as aptidões da inteligência emocional têm cinco domínios principais, "conhecer as próprias emoções, lidar com emoções, motivar-se, reconhecer emoções nos outros, lidar com relacionamentos" domínios estes, considerados pelos autores como necessários para viver bem.

Desta forma, percebe-se que conhecer as próprias emoções, ter autoconsciência acerca de um sentimento quando ele acontece é fundamental para a autocompreensão, se concretizando como o primeiro passo para o êxito ao lidar "gerenciar" as emoções. No entanto, é necessária uma busca constante da motivação para não perder o foco, por meio do estabelecimento de metas, com vistas ao desempenho eficaz. Estas aptidões são consideradas por Gardner (2000) como "inteligência intrapessoal", chave do autoconhecimento humano.

Reconhecer emoções no outro, também é elencado pelos autores como uma aptidão crucial para o desenvolvimento emocional inteligente, trazendo a escuta ativa como possibilidade fundamental de sintonia com o mundo, capacitando os sujeitos para interagir de forma positiva e construtiva. Gardner (2000) considera estas aptidões como, "inteligência interpessoal", capacidade de compreender outras pessoas.

Sobre a aptidão emocional Goleman (2012, p 60) afirma que, "é uma meta capacidade que determina até onde podemos usar bem quaisquer outras aptidões que tenhamos, incluindo o intelecto bruto". Por essa perspectiva, percebemos que o desenvolvimento da inteligência emocional, institui-se como a "mola mes- 
tra" propulsora da condução das reações emocionais, refletidas diretamente nas ações sociais dos sujeitos, pois conforme afirma o autor (p. 30) "quando se trata de moldar nossas decisões e ações, a emoção pesa tanto e às vezes muito mais - quanto a razão", o que torna imprescindível o entendimento das emoções, bem como compreender o desenvolvimento do processo inteligente do autoconhecimento das emoções e das reações emocionais para a conquista do equilíbrio emocional e bem-estar social do sujeito.

Em relação ao desenvolvimento da inteligência emocional Goleman (2012, p. 25), diz que "as lições emocionais que aprendemos na infância seja em casa ou na escola, modelam os circuitos emocionais, tornando-nos mais aptos - ou inaptos - nos fundamentos da inteligência emocional", o desenvolvimento emocional tem início no seio familiar e estende-se por todos os ambientes sociais. Desde cedo as crianças lidam social e emocionalmente com regras, falas, atitudes e exemplos que despertam suas emoções, no entanto, um maior cuidado e conhecimento deve ser dispensado à construção emocional positiva das crianças, especialmente na instituição família e na escola, em todas as suas etapas de ensino.

\section{Educação infantil no brasil: trajetória e concepções}

No Brasil, a educação infantil está entrelaçada à entrada das mulheres no mercado de trabalho. A partir dessa condição surgiram os primeiros espaços para abrigar as crianças de forma assistencial, muitas vezes em condições precárias de estruturas e higiene. Carac- 
terizada por uma relação de "favor" e por atendimentos empobrecidos, estes espaços se consolidaram como um "mal necessário".

Segundo Ortiz e Carvalho (2012), às creches e pré-escolas tiveram origens distintas. As creches surgiram como uma necessidade de organização e assistencialismo à mãe trabalhadora. Desse modo as creches nasceram de

iniciativa de mães trabalhadoras, igrejas, senhoras da alta sociedade, sindicatos, sem apoio governamental, como forma de atender aos mais pobres. Seu caráter era absolutamente assistencial e filantrópico e o objetivo explícito era a guarda da criança. (Ortiz e Carvalho, 2012, p. 19)

Nesse contexto, os espaços destinados às crianças eram caracterizados pelo teor de improvisação de estruturas físicas, recursos precários e quadro de profissionais sem formação específica, formado muitas vezes por voluntários, se constituindo como uma instituição improvisada e emergencial. Ainda conforme as autoras, a pré-escola nasceu, a partir das ideias de Froebel, na Alemanha, em 1960.

O grande marco para educação infantil, veio com a Constituição Federal de 1988, que regulamentou o atendimento em creche e pré-escola às crianças de zero a 06 anos, reconhecendo esta etapa como parte integrante do sistema educacional do Brasil, sob a responsabilidade do Estado. Esta regulamentação também está contida na lei federal n.o 8069 de 1990, Estatuto da Criança e do Adolescente - ECA, que traz o atendimento às crianças dessa faixa etária em creches e pré-escola como um direito. Posteriormente com a promulgação da Lei de Diretrizes e Bases da Educação Nacional n.o 9394/1996, 
rompendo com a visão assistencialista, a educação infantil passou a integrar à educação básica sob a responsabilidade dos municípios.

Atualmente a educação infantil atende às crianças de zero a 05 anos, em virtude da alteração ocorrida no ano de 2006 que estabelece para acesso ao ensino fundamental a faixa etária de 06 anos.

Conforme os documentos oficiais para educação infantil, a concepção de educação para esta etapa de ensino deve vincular o educar e o cuidar, rompendo com a visão de que a creche e a pré-escola, são espaços apenas para o cuidado. Nesse sentido, a visão adultocêntrica, ao longo dos anos, foi gradativamente substituída pelo conceito de criança como sujeito de direitos, que tem suas peculiaridades e necessita experienciar a infância, etapa fundamental do desenvolvimento humano.

A educação infantil primeira etapa da educação básica tem como finalidade a formação integral das crianças, em seus aspectos físicos, psicológicos, intelectuais e sociais complementando as ações das famílias e da comunidade, conforme é preconizado no artigo 29 da Lei 9394/1996, Lei de Diretrizes e Bases da Educação Nacional. Desse modo, há uma compreensão que esta etapa de ensino abrange todas as formas educacionais de interação das quais as crianças participam, seja em seu ambiente familiar, escolar ou social ao qual estão inseridas.

Nesse processo colaborativo para o desenvolvimento integral das crianças, compreende-se que à instituição escolar é instituído maior empenho e dedicação profissional, por ser um espaço educacional que traz em sua essência a marca de ser "lócus" do desenvolvimento educacional. Em se tratando da educação infan- 
til, conforme a Base Nacional Comum Curricular, nas últimas décadas esta etapa de ensino vem consolidando a concepção que vincula o cuidar e o educar, compreendendo que o cuidado é indissociável ao processo educativo.

As interações desenvolvidas na educação infantil devem estar alinhadas ao desenvolvimento dos direitos de aprendizagem para a educação infantil estabelecidos na BNCC, assegurados às crianças o direito de conviver com seus pares e adultos, o direito de brincar diariamente, de diversas formas e em variados espaços, o direito de participar e decidir, se posicionando nas escolhas da rotina escolar, o direito de explorar, o corpo, o ambiente, a natureza, o direito de expressar suas necessidades e emoções, utilizando diferentes linguagens e o direito de conhecer-se e construir sua identidade pessoal, social e cultural.

Nessa perspectiva, as vivências desenvolvidas na educação infantil devem estar diretamente ligadas ao desenvolvimento integral das crianças, considerando os aspectos particulares e coletivos que potencializam e favorecem tal desenvolvimento, entendendo assim, que as crianças constroem sua identidade ao longo da vida por meio da relação consigo mesmo e nas relações com seus pares, em um processo dinâmico e complexo, permeado de intencionalidades educativas por parte dos profissionais da educação infantil.

\section{Inteligência emocional no contexto da educação infantil}

As Diretrizes Curriculares Nacionais da Educação Infantil (DCNEI, Resolução no 5/2009), em seu artigo 4ํ, definem a criança como 
sujeito histórico e de direitos que, nas interações, relações e práticas cotidianas que vivencia, constrói sua identidade pessoal e coletiva, brinca, imagina, fantasia, deseja, aprende, observa, experimenta, narra, questiona e constrói sentidos sobre a natureza e a sociedade, produzindo cultura (BRASIL, 2009).

Em seu artigo 9.0, as DCNEI institui que as interações e as brincadeiras são os eixos estruturantes das práticas pedagógicas dessa etapa de ensino, possibilitando experiências nas quais as crianças possam construir e apropriar-se de conhecimentos sobre si e sobre o "mundo", por interações com seus pares e com os adultos, o que possibilita o autoconhecimento, a concretização de aprendizagens significativas e o desenvolvimento integral dos sujeitos, bem como sua socialização.

$\mathrm{Na}$ educação infantil as interações devem assegurar às crianças os direitos de conviver, brincar, explorar, participar, expressar-se e conhecer-se, organizados e estruturados em cinco campos de experiências, que devem acolher as experiências e situações cotidianas das crianças, "complementando a ação da família e da comunidade", conforme artigo 29, da Lei de Diretrizes e Bases da Educação 9394/1996.

Assim como as interações, a brincadeira é indispensável na infância. É por meio do brincar que a criança desenvolve seu sistema emocional, psíquico e cognitivo. $O$ ato de brincar possibilita vivências, exploração, experimentação e interação, oportunizando a tomada de decisões e resolução de conflitos.

Desse modo, para assegurar a efetivação dos direitos de aprendizagem dessa etapa de ensino, as práticas pedagógicas desenvolvidas devem ser caracterizadas pelo comprometimento com a construção intencional 
de processos educativos que promovam aprendizagens sintonizadas com as necessidades, as possibilidades e os interesses dos estudantes e com os desafios da sociedade contemporânea, considerando as diferentes infâncias (BRASIL, 2018). Como sujeitos em desenvolvimento, as crianças desde os primeiros meses de vida, constituem-se no contato diário com adultos e com outras crianças, aprendendo sobre o próprio corpo, sobre o corpo do outro, sobre os objetos e sobre a natureza. Nas relações estabelecidas no ambiente escolar, as ações pedagógicas desenvolvidas devem expressar a responsabilidade e compromisso com a integralidade da criança em todos os seus aspectos, considerando sua totalidade, sem compartimentá-la.

Para Goleman (2012, p. 25), "a infância e a adolescência são ótimas oportunidades para determinar os hábitos emocionais básicos que irão governar nossas vidas". Percebe-se assim que, a educação escolar, e em especial a educação infantil, pode contribuir de modo significativo para o despertar consciente das emoções das crianças, por mediações interativas que coadunem os conhecimentos culturais acumulados historicamente e o entendimento das emoções por parte de cada criança, propiciando um agir ético e humano perante a sociedade.

Para Alfandéry (2010, p. 71), "é inevitável que as influências afetivas que rodeiam a criança desde o berço tenham sobre sua evolução mental uma ação determinante”, nesse sentido, para colaborar com o desenvolvimento da inteligência emocional é fundamental que as práticas pedagógicas imprimam em sua "essência", "intencionalidade educativa", permeadas por experiências que considerem a criança com centro de toda ação pedagógica, bem como sua identidade e sua realidade 
emocional e social, proporcionando possibilidades de autoconhecimento, conhecimento e compreensão das relações sociais por situações planejadas/medidas que tenham como objetivo promover o desenvolvimento integral das crianças.

\section{Desenvolvimento emocional infantil no ensino remoto}

O aparecimento da Covid-19, cujos estudos apontam que teve origem em 2019 na cidade de Wuhan na China provocou modificações em todas as esferas sociais do mundo moderno. A infecção humana pelo vírus em um curto espaço de tempo foi declarada pela Organização Mundial de Saúde (OMS) como sendo uma pandemia, seu acelerado contágio e os altos índices de mortalidade demandaram das autoridades de governos internacionais e nacionais a adoção de medidas estratégicas para a preservação da vida.

Dentre as medidas adotadas para combater o vírus podemos citar o uso de máscara, higienização das mãos e o isolamento social, medidas estas que, enquanto pareciam simples, afetou profundamente a vida humana em todos os aspectos: emocionais, sociais, econômicos e culturais.

O novo contexto impactou fortemente as relações interpessoais e com a esfera educacional, que teve como primeira medida a suspensão das atividades escolares por leis e decretos federais, estaduais e municipais de deliberação e normatização de medidas para enfrentamento a Covid-19. Diante da nova realidade, o ensino remoto possibilitou a continuidade do percurso escolar, no entanto, esse novo modelo de ensino instigou e ainda 
necessita de uma maior preparação e compromisso de todos os profissionais envolvidos no processo de ensino e aprendizagem, convidados a repensar diariamente os caminhos da educação escolar, no intuito de atender as necessidades básicas dos estudantes, como garantir seus direitos de aprendizagens.

Assim, repensar as práticas pedagógicas no âmbito escolar foi uma necessidade vital e urgente, sobretudo na educação infantil, que tem como eixos estruturantes as interações e brincadeiras como base de todas as ações desenvolvidas nessa etapa de ensino, conforme é estabelecido no artigo 9.0 das Diretrizes Curriculares Nacionais para a Educação Infantil. Em meio a este cenário, a tecnologia tornou-se aliada potente para o "encontro" da escola com as famílias, fortalecendo as mediações diárias com as crianças, fortalecendo vínculos e contribuindo positivamente na educação das crianças e de forma especial no desenvolvimento emocional, por experiências lúdicas estreitando suas relações pessoais e coletivas, exercendo o protagonismo no processo de desenvolvimento emocional, conforme apresentaremos a seguir.

\section{Trabalhando as emoções na Emeief Francisco Antônio Fontenele}

As experiências na educação infantil devem ser organizadas para possibilitar a construção da identidade pessoal, social e cultural das crianças. No município de Maracanaú, lócus do nosso exercício profissional, atenção especial é dada a esta etapa de ensino, acerca do favorecimento e implementação de metodologias para o desenvolvimento emocional qualitativo das crianças, especialmente em meio ao atual cenário pandêmico, 
trazendo grande relevância para a formação crítica e reflexiva dos educandos.

O fazer pedagógico diário das instituições de educação infantil do município buscam garantir os direitos de aprendizagem das crianças para colaborar na construção do seu desenvolvimento integral, cognitivo, emocional e social, por meio do desenvolvimento de atividades que possibilitem a participação das crianças, usando diferentes linguagens, ampliando o conhecimento sobre si e sobre o outro, estimulando-as a expressar suas necessidades e emoções, sentimentos, dúvidas e descobertas, vivenciando experiências significativas de cuidados, interações e brincadeiras.

De acordo com Goleman (2012, p. 135) "a maior parte do contágio emocional é muito mais sútil, parte de um tácito intercâmbio que ocorre em qualquer interação com o outro. Transmitimos e captamos modos uns com os outros (...) alguns encontros são tóxicos, outros, revigorantes", desta forma na EMEIEF Francisco Antônio Fontenele buscamos colaborar de forma positiva no desenvolvimento emocional das crianças, por práticas metodológicas intencionalmente planejadas, que considerem as emoções das crianças e seus desdobramentos, colocando-as no centro de todo processo educacional, conforme descrição das atividades a seguir.

No atual cenário pandêmico, as professoras da educação infantil da escola desenvolveram interações de acolhimento de ideias, incentivando a participação das crianças mesmo de forma remota, buscando fortalecer o vínculo afetivo com as crianças e as famílias, favorecendo assim o desenvolvimento individual e coletivo.

No desenvolvimento da atividade "Os amores da minha vida" realizada na turma do Pré II, evidenciando 
o campo de experiência o eu, o outro e nós, a professora por meio do acolhimento de ideias, diálogos interativos, buscou estimular o processo de autoconhecimento das crianças, ressaltando o desenvolvimento do sentimento de pertencimento a determinados grupos (família, amigos, escola, etc.), enfatizando a importância da empatia em nosso cotidiano e a percepção por parte das crianças, que as pessoas têm diferentes sentimentos, necessidades e maneiras de pensar e agir.

A atividade foi realizada de forma on-line, as crianças assistiram vídeo sobre a temática, participaram descrevendo seus sentimentos, momentos afetivos vivenciados, exploraram suas memórias, em seguida a professora sugeriu que as crianças desenhassem suas mãozinhas, escrevessem seu nome no centro e nos dedos escrevessem com ajuda de um adulto os nomes das pessoas sendo os amores da vida de cada uma.

$\mathrm{Na}$ atividade "conhecendo minhas emoções", no campo de experiência o eu, o outro e nós" desenvolvida na turma do Pré I, a professora por interações virtual e apresentação do vídeo "cara de que", estimulou as crianças a perceberem suas emoções, em que momentos e elas "afloram", a raiva, o medo, a alegria, colaborando assim na compreensão das próprias emoções, bem como no exercício da empatia por parte das crianças.

Essas atividades proporcionaram vários desdobramentos, possibilitando a reflexão e compreensão do contexto familiar das crianças, conhecimento esses que se constituem em pontos fundamentais para reflexão e para o compartilhamento do cuidado e educação das crianças, tornando as práticas desenvolvidas carregadas de significados e potentes na colaboração no desenvolvimento qualitativo das emoções das crianças. 


\section{Vivências emocionais na Emeief Governador César Calls De Oliveira Filho}

A experiência mais marcante que vivemos no ensino remoto na EMEIEF Governador César Cals de Oliveira Filho e em especial na Educação Infantil, foi entender que estar junto não significa necessariamente estar perto e que mesmo a distância um professor pode transformar o seu fazer pedagógico em prol do aluno e de sua família.

Para tanto, as professoras tiveram que pensar em novas formas de interação e envolvimento das crianças no cotidiano, bem como repensar sempre que necessário a ação docente no processo de ensino e aprendizagem a partir da concepção que vincula educar e cuidar, entendendo o cuidado como algo indissociável do processo formativo. Aproveitando as vivências e os conhecimentos das crianças construídos nos ambientes familiares e sociais, para integrar as ações pedagógicas e ampliar o universo de experiências, conhecimentos e habilidades das mesmas, diversificando e consolidando novos conhecimentos.

Desenvolvendo atividades lúdicas e voltadas para despertar nas crianças o interesse pelo conhecimento e as diversas formas de ver o mundo através do compartilhamento de responsabilidades. Desta forma, as professoras em parceria com sua coordenação procuraram no período pandêmico planejar estratégias para montar uma rotina de acolhidas às crianças e as famílias com foco no desenvolvimento das competências e habilidades voltadas para melhor compreensão e construção sócio emocional das crianças.

O acolhimento e desenvolvimento das emoções se constitui em uma prática pedagógica básica, trabalha 
nas turmas on-line diariamente, onde por meio da escuta ativa as professoras da educação infantil direcionaram suas atividades, trazendo a voz das crianças para a organização e implementação do planejamento pedagógico. Já nesse momento inicial da rotina escola, as crianças estimuladas pelas docentes, estão sempre abertas a participarem, contagiadas pelo acolhimento encantador das mediadoras participam naturalmente da interação, dialogando sobre suas ideias, seus medos, suas alegrias e seus desejos, momentos estes de grande significado na construção individual e coletiva das crianças.

Nas turmas do Pré II, o momento da acolhida é um momento potencializador da rotina das crianças, fomentando várias outras atividades pedagógicas. Outro momento bastante colaborativo são as "lives" organizadas conforme o "termômetro" da necessidade observada pelas professoras. Nas lives as crianças fortalecem os vínculos com os colegas de turma e professoras, nesses momentos é possível perceber como as crianças estão emocionalmente e por meio da reflexão-ação, as professoras buscam mediar as situações observadas para colaborar com o bem-estar emocional das crianças e das famílias, pois compreendemos que trabalhar emoções é crucial para o desenvolvimento integral do ser humano.

\section{Considerações Finais}

Nesse estudo, tivemos como objetivo principal realizar uma análise da possibilidade do desenvolvimento da inteligência emocional na educação infantil, em tempos de ensino remoto.

À vista do que foi exposto, concluímos que o desenvolvimento emocional das crianças está intrínseco ao 
seu processo de desenvolvimento integral, demandando conhecimento e reflexão dos profissionais educacionais, acerca dos conceitos que norteiam a concepção do desenvolvimento emocional e as ações pedagógicas a serem implementadas no processo formativo da educação infantil.

Assim, mesmo diante do cenário atípico ocasionado pelo covid-19 e os impactos sofridos por todos os setores da sociedade e na sua capacidade de enfrentar os desafios é possível identificar diversas estratégias para enfrentamento desse novo cenário, sobretudo no sistema educacional, tendo em vistas a necessidade de redefinir seus "caminhos" de implementação de experiências significativas para construção e desenvolvimento emocional das crianças em seus aspectos cognitivos, sociais e culturais.

As práticas pedagógicas vivenciadas na EMEIEF Francisco Antônio Fontenele e na EMEIEF Governador César Calls de Oliveira Filho, apresentam evidências de experiências exitosas no processo de construção de vínculos afetivos e na colaboração do bem-estar emocional das crianças, por ações e estratégias construídas a partir de atividades remotas.

Procuramos a partir deste trabalho, contribuir com a reflexão sobre o desenvolvimento emocional de crianças, na idade escolar da educação infantil, em suas experiências educacionais e interações no conjunto de atividades vivenciadas em seu cotidiano.

Compreendemos que vivenciamos um momento novo, que ainda requer aprofundamentos e uma constante reflexão das metodologias a serem implementadas acerca desta temática. No entanto, acreditamos ter atingido com nossos estudos os objetivos propostos. 


\section{Referências}

ALFANDÉRY. G. Hélène, Henri Wallon. Tradução: Patrícia Junqueira. Org. Elaine T.D.M. Dias - Recife: Fundação Joaquim Nabuco, Ed. Massangana, (Coleção Educadores), 2010.

BRASIL. Base Nacional Comum Curricular. Brasília: BNCC, 2018. Disponível em: http://basenacionalcomum.mec.gov.br. Acesso em 02 de ago. de 2021.

. Lei n. 8069, de 13 de julho de 1990. Estatuto da Criança e do Adolescente. Disponível em: https://www. gov.br. Acesso em 05 de ago. de 2021.

Lei n. 9394, de 20 de dezembro de 1996. Lei de Diretrizes e Bases da Educação nacional. Brasília: MEC, Disponível em: http://www.planalto.gov.br/ccivil_03/ leis/19394.htm. Acesso em 02 de ago. de 2021.

Resolução CNE/CEB no 5, de 17 de dezembro de 2009. Disponível em: http://portal.mec.gov.br/. Acesso em 06 de ago. de 2021.

GARDNER, Howard. Inteligências Múltiplas: a teoria na prática. Porto Alegre: Artes Médicas, 2000.

GOLEMAN. Daniel, ph.D. Inteligência Emocional: a teoria revolucionária que redefine o que é ser inteligente. 2. ed. Rio de Janeiro: Objetiva, 2012.

ORTIZ. Cisele; CARVALHO. Maria Teresa Venceslau. Interações: ser professor de bebês - cuidar, educar e brincar, uma única ação. Editora Edgar Blucher. São Paulo. 2012.

SALOVEY, P.; MAYER, J. D. Emotional intelligence. Imagination, Cognition and Personality, 9, 185-221, (1990). 


\title{
A PANDEMIA E SEUS IMPACTOS NO AGRAVAMENTO DE DISTÚRBIOS SOCIOEMOCIONAIS EM DOCENTES E DISCENTES
}

\author{
Raquel Matias Costa Queiros ${ }^{1}$ \\ Gabia Cavalcante Lima² \\ Lia de Queiróz Ferreira ${ }^{3}$ \\ Iury Torquato de Almeida ${ }^{4}$
}

\section{Considerações iniciais}

Atualmente, são vivenciados momentos de novos desafios diante de um mundo em profundas transformações, tanto nos aspectos políticos, econômicos e sociais, exigindo da sociedade inúmeras adaptações, tendo em vista as circunstâncias impostas pela pandemia que tem assolado o cenário mundial, a COVID - 19, causada pelo vírus Sars-Cov-2, considerado um novo tipo de pneumonia, provocando o adoecimento da população.

1 Graduada no Curso de Formação de Professores; para Ensino Fundamental de $1^{\circ}$ a $8^{\circ}$ séries, nas Áreas Específicas - UECE; Especialista em Administração Escolar - UVA; Professora no município de Maracanaú/CE; Professora no município de Maranguape/ CE; Email: gabiaprofessora-22@hotmail.com

2 Graduada em Letras Português/Literatura - UFC; Especialista em Metodologia do Ensino Fundamental e Médio- UVA; Especialista em Gestão e Coordenação Escola - UNIRB; Coordenadora escolar do município de Maracanaú/CE; E-mail: rachelmatias34@gmail.com

3 Graduada em Pedagogia - UNIFOR; Especialista em Educação de Jovens e Adulto- IFCE; Especialista em Gestão e Coordenação Escolar - FACESMA; Coordenadora escolar do município Maracanaú/CE; E-mail: liaqueiroz1963@hotmail.com

4 Graduado em Administração - FAK; Licenciado em Pedagogia - FAK; Especialista em Gestão de Projetos - ABED; Especialista em Psicologia Organizacional e do Trabalho - FAK; Especialista em Gestão Escolar - FAESL; Especialista em Docência do Ensino Superior - FAK; Especialista em Gestão e Tutoria - UNIASSELVI; Mestre em Gestão de Negócios Turísticos - UECE; Doutor em Ciências da Educação - USC/PY; E-mail: iuryt.almeida@gmail.com 
Nesse sentido, para o enfrentamento da pandemia, segundo relatos de alguns especialistas, dentre estes, Schorn e Sehn (2021), medidas foram adotadas, provocando mudanças na rotina e nos hábitos de grande parte da população, como o isolamento de famílias, fechamento de comércio, bancos, universidades, escolas entre outras instituições, que em sua maioria, foram fechadas, trazendo impactos para todos, especialmente, estudantes e professores em geral, colocando em evidência o contexto educacional.

Nesse entendimento, aponta também Saviani (2020), que a pandemia inseriu gradativamente, um conjunto de dilemas, no âmbito educacional, como a organização pedagógica de ensino, o atendimento individualizado aos estudantes, o ensino remoto virtual, para ser garantido o prosseguimento das aulas, sem perdas e danos ao ano letivo.

No que lhe concerne, reportando-se aos efeitos e consequências do ensino remoto, Holmes (2020), ressalta principalmente, os problemas emocionais, face às exigências dos profissionais na adaptação do seu currículo com incorporação dos recursos tecnológicos e de comunicação, além dos recursos socioemocionais.

Em face disto, o artigo em questão, trata da Pandemia e seus impactos no agravamento de distúrbios socioemocionais em docentes e discentes, tendo em vista as consequências provocadas pelo distanciamento social e as alterações das rotinas e hábitos de grande parte dessa população, como perdas da liberdade, sobrecarga laboral e precarização das condições de ensino e aprendizagem, levando à ansiedade e depressão, trazendo como foco de investigação: quais as consequências causadas pela pandemia que assola o cenário mun- 
dial? Quais os impactos provocados no agravamento de distúrbios socioemocionais em docentes e discentes?

Com a intenção de responder aos problemas em questão, ressalta-se como objetivo analisar os impactos da pandemia no agravamento de distúrbios socioemocionais em docentes e discentes. Os objetivos específicos visam descrever as consequências da pandemia na educação; identificar os tipos de distúrbios socioemocionais e seus sintomas; relacionar a importância das competências socioemocionais na relação professor-aluno diante da pandemia.

Na perspectiva de discutir sobre essas questões, vários especialistas, dentre eles Saviani (2020), Santos (2020), Schorn e Sehn (2021), e outros estudiosos fundamentam o estudo, tendo ainda como suporte teórico, algumas legislações pertinentes como a BNCC, Decretos e Resoluções.

Nesta pesquisa, recorreu-se a uma metodologia de investigação de cunho bibliográfico descritivo com abordagem qualitativa, a partir de referências publicadas em livros, revistas e pesquisas em biblioteca eletrônica que abrange uma coleção selecionada de periódicos científicos brasileiros, analisando e discutindo as contribuições culturais e científicas

Desse modo, encontram-se distribuídos, a seguir, os resultados dessa articulação teórica, contextualizando inicialmente, as consequências da pandemia nos diferentes contextos mundial, nacional e no cenário educacional e as adaptações para o seu enfrentamento, em seguida, trata-se dos distúrbios socioemocionais e seus sintomas; bem como da importância de relacionar as competências socioemocionais como contribuições 
para minimizar os impactos gerados diante do cenário de crise pandêmica.

\section{As consequências da pandemia nos diferentes contextos mundial, nacional e no cenário educacional e as adaptações para o seu enfrentamento}

No início do ano de 2020, o cenário mundial vivenciou uma situação de Emergência de Saúde Pública de Âmbito Internacional em razão do surgimento de um novo coronavírus, na China, em dezembro do ano anterior. Já em 11 de março de 2020, a COVID-19, doença causada pelo vírus Sars-Cov-2, foi declarada pela Organização Mundial da Saúde (OMS) como "pandêmica", pois, registrava-se a epidemia de uma doença infecciosa, provocando uma situação de calamidade pública, de perturbação mundial (SANTOS, 2020).

Diante deste cenário, algumas reflexões acerca dessa pandemia podem ser apontadas, tendo em vista, segundo estudos de Barbosa e Almeida (2021), que a OMS iniciou discussões para o seu enfrentamento, como adoção de medidas empregadas pela situação de emergência impostas. Outro estudioso do assunto, Khatib (2021, p. 4), revelou que além do Brasil "[...] em 13 de março de 2020, 61 países na África, Ásia, Europa, Oriente Médio, América do Norte e América do Sul anunciaram ou implementaram o fechamento de atividades econômicas, além de escolas e universidades".

Barbosa e Almeida (2021), trazem algumas definições acerca dessa doença, com base no Ministério da Saúde (BRASIL, 2020), a saber:

A COVID-19 é uma doença causada pelo coronavírus, denominado SARS-CoV-2, que apresen- 
ta um espectro clínico variando de infecções assintomáticas a quadros graves. De acordo com a Organização Mundial de Saúde, a maioria (cerca de 80\%) dos pacientes com COVID-19 podem ser assintomáticos ou oligossintomáticos (poucos sintomas), e aproximadamente $20 \%$ dos casos detectados requer atendimento hospitalar por apresentarem dificuldade respiratória, dos quais aproximadamente $5 \%$ podem necessitar de suporte ventilatório (BRASIL, 2020, n.p.1).

É importante afirmar que os desafios foram imensos para a população brasileira e mundial para se adaptarem a essa doença, tendo em vista as suas consequências e sequelas, ao observar o desenrolar dos acontecimentos, diante das dificuldades, temores e acesso aos hospitais e ao isolamento social imposto e políticas públicas adotadas.

Com relação às características da Pandemia, segundo Cordeiro (2021, p. 7), "[...] denominação que se caracteriza quando há um aumento elevado de número de casos de uma determinada doença, acima do esperado em uma região e extrapola para outros lugares do país e ainda se estende por diversas regiões do planeta". Em um cenário de medo e instabilidade foram tomadas várias medidas para conter o avanço da pandemia, era preciso reunir forças de toda a sociedade para enfrentar o surto. As autoridades de saúde de todos os países afetados, recomendaram o isolamento social como estratégia para conter o contágio.

Nessa intenção, as medidas de combate para essa doença ocasionaram diversas publicações em jornais, revistas, e inúmeras reportagens, sobretudo visando conter a disseminação do vírus, entre outras, o Jornal 
Correio Braziliense, publicado online no dia 1 de abril do corrente ano, descreveu:

A Portaria 356, do Ministério da Saúde, de 11 de março, disciplina as iniciativas que podem ser adotadas para o combate à epidemia do vírus no país. O isolamento é definido como a ação que "objetiva a separação de pessoas sintomáticas ou assintomáticas, em investigação clínica e laboratorial, de maneira a evitar a propagação da infecção e transmissão local”. Ela só pode ser definida por prescrição médica. Já a quarentena, tem como objetivo "garantir a manutenção dos serviços de saúde em local certo e determinado”. E tem de ser determinada por secretarias de Saúde de estados e municípios ou pelo Ministério da Saúde, e pode durar 40 dias, prorrogáveis, se necessário.

No Boletim Epidemiológico 5 do Ministério da Saúde, de 14 de março, o órgão estabeleceu a quarentena quando a ocupação dos leitos de Unidade de Terapia Intensiva (UTI) chegar a $80 \%$ da capacidade mobilizada para resposta à Covid-19.

Cada estado utiliza termos específicos para se referir às medidas de distanciamento social. A Agência Brasil traz a seguir cinco exemplos, a partir da seleção das cinco unidades da federação com mais casos confirmados de coronavírus no país (CORREIO BRASILIENSE, 2020, in BARBOSA; ALMEIDA, 2021, p. 124).

As medidas de isolamento social foram estabelecidas por Decretos nos diversos Estados e Municípios brasileiros, daí o isolamento forçado. Em casos mais extremos onde índice de mortes por conta da Covid-19, fora muito alto, as autoridades decretaram o lockdown, e o fechamento quase total do comércio e de alguns serviços considerados essenciais. 
Enfim, diante de um contexto de isolamento social, com fechamento de comércio, reuniões por videoconferências, vendas por delivery e o trabalho em home office, as demais instituições, como as escolas, tiveram que adotar medidas alternativas para manutenção e continuidade das atividades letivas, com a necessidade de manter os serviços educacionais ativos (BARBOSA; ALMEIDA, 2021).

No âmbito atual, cada vez mais há o consenso acerca da comparação entre ambiente presencial e virtual de aprendizagem, tendo em vista, a necessidade de reflexão sobre os professores estarem preparados para ensinar em ambientes online, bem como quais as mudanças nos paradigmas tradicionais de ensino devem ser consideradas para essa transposição.

Nessas dimensões, diante das mudanças ocorridas por ocasião do isolamento social submetido, o sistema educacional em ensino remoto, procurou adaptar-se, pois grande parte dessa população em casa sofreu impactos psicológicos, como depressão e ansiedade, necessitando de protocolos sanitários repensados e fundamentais para um retorno seguro.

Nesse sentido, reportando-se aos estudos de Crawford et al. (202), acerca da COVID-19 e respostas de pedagogia digital intra-período do ensino superior de 20 países, sua contribuição aponta que essa passagem precisa acontecer de forma cautelosa, por conta de nem todos os alunos terem acesso às ferramentas digitais e os professores não estarem adaptados ao modelo, pois precisam de preparação didática e competências socioemocionais para tanto. 


\section{Tipos de distúrbios socioemocionais e seus sintomas no cotidiano escolar}

As competências socioemocionais segundo Oliveira et al (2021), incluem um conjunto de habilidades necessárias para cada indivíduo lidar com as próprias emoções, relacionar-se com outros e gerenciar objetivos de vida, sobretudo nas resoluções de problemas.

Dessa maneira, ao adentrar nestas habilidades, cabe antecipadamente, delinear acerca dos distúrbios socioemocionais que tanto desgastam a população em geral, neste caso, especificamente, professores e alunos em tempos de isolamento e cenário pandêmico no cotidiano escolar.

Conforme Marques (2021), distúrbio ou transtorno emocional é uma patologia caracterizada por grande mal-estar físico e psíquico, ou seja:

[...] modificação da saúde mental de uma pessoa, que deixa o bem-estar desta em baixa. São basicamente alterações que ocorrem no funcionamento da mente de um indivíduo, afetando o seu humor, raciocínio, comportamentos, atitudes, bem como o desempenho, tanto na vida pessoal, quanto na profissional (MARQUES, 2021, p. 1).

Trata-se, portanto, de um tipo de problema muito sério, transformando-se em uma das principais causas de incapacitação e afastamento trabalhista, segundo dados comprovados pela Organização Mundial da Saúde (OMS), podem ser apresentados por ansiedade, depressão, estresse, fobia social, síndrome do pânico, entre outros (MARQUES, 2021).

Diante desses dados apresentados, com base nos relatos de Marques (2021), a seguir destacam-se algumas das principais características e formas de trata- 
mentos desses distúrbios, que tem afetados estudantes e professores nesses tempos de ensino não presencial, pois no espaço virtual, mesmo que até o momento não seja possível precisar a dimensão dos efeitos e os seus desdobramentos, muitos têm sido evidenciados.

Depressão: tem sua origem na confluência de fatores emocionais, mentais e físicos. O paciente depressivo possui um forte desequilíbrio químico que afeta os seus neurotransmissores. Os sintomas podem ser tanto de ordem emocional quanto física, sendo que a tristeza persistente e profunda é o traço mais marcante da doença. Para o tratamento, há necessidade de acompanhamento médico constante incluindo uso de medicamentos e terapia.

Ansiedade: considerado um grave transtorno emocional que prejudica a vida social e profissional do indivíduo, que não consegue dissociar-se desse foco, sofrendo muito. Para o tratamento o médico deve verificar se a ansiedade está ligada a uma doença física ou a um distúrbio de origem emocional, ou os dois, que pode levar ao uso de medicamentos e terapia.

Síndrome do pânico: um dos transtornos emocionais mais frequentes atualmente, desencadeada por situações estressantes ou traumáticas, acontecem de forma inesperada, tendo sintomas emocionais e físicos que podem levar o indivíduo até um desmaio. $O$ tratamento pode ser feito por psicoterapia e medicamentos.

Estresse: conhecido pelo mal do século, está presente na vida de grande parte da população mundial. Manifesta-se de maneiras diversas (irritação, descontrole emocional, choro e extrema preocupação, fortes dores de cabeça, estômago, pelo corpo, bruxismo, sudo- 
rese, tremores e tonturas). Dependendo do caso, para tratamento, o paciente pode precisar de terapia.

Diante desses distúrbios, para saber se uma pessoa está passando por algum transtorno emocional ou comportamental, deve-se ficar atendo, para levá-la aos profissionais de saúde mental e centros de tratamento que podem avaliar e determinar o modo de tratar.

\section{Importância de relacionar as competências} socioemocionais como contribuições para minimizar os impactos gerados diante do cenário de crise pandêmica.

Diante das análises e acompanhamentos das mudanças de rotinas que ocorreram na vida dos professores e alunos nesse tempo de transposição do ensino presencial para o espaço virtual, a adequação do aprendizado foi necessária e nesse processo, as competências socioemocionais (CSE), tem ganhado destaque recentemente, pois segundo Marques (2021), elas são parte do desenvolvimento individual pelo qual todos passamos ao longo da vida e engloba também aspectos físicos (bem-estar) e culturais (identidade e diversidade), além do intelectual.

Para Marques (2021), algumas das habilidades que formam o conjunto de competências socioemocionais são: autoestima, autoconfiança, facilidade para fazer amigos, autocontrole, persistência, resolução de problemas, autonomia, foco, paciência, boa comunicação, empatia e conhecimento em relação ao que é moralmente certo e errado. Estas habilidades citadas são parte da vida e necessárias nas mais diferentes situações. Por isso, o papel do professor torna-se pri- 
mordial não apenas em relação à transmissão de conteúdos, mas também no que diz respeito às estratégias emocionais que podem ser construídas no diálogo professor-aluno.

Para Schorn e Sehn (2021), as competências socioemocionais estão presentes em praticamente todas as situações experimentadas ao longo da vida. Por isso, alunos que apresentam maior facilidade de aprender os conteúdos escolares têm competências socioemocionais desenvolvidas, pois estas interagem com as competências cognitivas, promovendo um avanço na aquisição de conteúdos de diversos componentes curriculares o que, consequentemente, aumenta a perspectiva futura de educação e carreira.

Desse modo, é importante relacionar as competências socioemocionais como contribuições para minimizar os impactos gerados diante do cenário de crise pandêmica, que põe em evidência a crítica situação da educação brasileira e a desigualdade social no país, revelando a ausência de formação continuada dos professores, de recursos tecnológicos no cotidiano escolar e a dificuldade de acesso de alunos e professores a esses recursos.

Para tanto, a adequação do aprendizado significa ter o foco na aprendizagem, do que é mais importante desenvolver segundo previstos na Base Nacional Comum Curricular (BNCC, 2017), como as habilidades socioemocionais, reorganizar conteúdos conforme a nova realidade educacional, rever e adaptar objetivos, avaliar e criar estratégias de recuperação da aprendizagem para aqueles alunos que se encontram em dificuldades, sobretudo, encaminhando para profissionais que poderão ajudá-los, caso necessitem. 


\section{Considerações finais}

Em virtude da determinação do fechamento setores econômicos e financeiros, restaurantes e demais, sendo ainda prioridade, que os setores não essenciais fechassem as portas e os cidadãos se recolhessem em suas casas, as escolas também vivenciaram momentos de novos desafios, exigindo inúmeras adaptações, tendo em vista as circunstâncias impostas.

Dessa forma, os impactos no agravamento de distúrbios socioemocionais em docentes e discentes foram de certa forma acentuados, tendo em vista as consequências provocadas pelo distanciamento social e as alterações das rotinas e hábitos de grande parte dessa população, sobretudo, com a sobrecarga laboral e precarização das condições de ensino e aprendizagem, levando à ansiedade e depressão.

O cenário desafiador e inesperado provocou inúmeros transtornos, necessitando a compreensão de novas metodologias de ensino, das competências socioemocionais como primordiais para manejar com as circunstâncias impostas pela pandemia, em particular, para auxiliar na retomada das atividades presenciais.

Nesses termos, apesar das contribuições para esse estudo, aponta-se a importância de estudos futuros para desdobramentos da pandemia para a saúde mental do professor no intento de identificar os reais efeitos do cenário de crise.

\section{Referências}

BARBOSA, Silvia Danizete Pereira.; ALMEIDA, Daiane Vithoft de. O ensino remoto emergencial: mediação tecnológica e estratégias de ensino-aprendizagem. Cader- 
no Intersaberes, v. 9, no 22, p.123-136, Centro Universitário Internacional Uninter, 2020.

BRASIL/MEC. Lei no. 9.394, de 20 de dezembro de 1996. Lei de Diretrizes e Bases da Educação Nacional. Brasília, DF: 20 de dezembro de 1996.

Base Nacional Comum Curricular (BNCC). Educação é a Base. Brasília, MEC/CONSED/UNDIME, 2017.

Ministério da Saúde. O que é COVID-19. 2020. Disponível em: https://coronavirus.saude.gov.br/sobre-a-doenca. Acesso em: 26. 05. 2021.

CRAWFORD, J., BUTLER-HENDERSON, K., RUDOLPH, J., GLOWATZ, M. COVID-19: 20 respostas da pedagogia digital intra-período do ensino superior dos países. Journal of Applied Teaching e Aprendizagem (JALT), 3 (1), 1-21. Disponível em:〈https://doi.org/10.37074/ jalt.2020.3.1.7 . Acesso em: 28.09.2021.

CORDEIRO, Karolina Maria de Araújo. O impacto da pandemia na educação: a utilização da tecnologia como ferramenta de ensino. Disponível em:/http://idaam. siteworks.com.br/bitstreamrefix〉. Acesso em: 03. 06. 2021.

HOLMES, Emily A. et al. Prioridades de pesquisa multidisciplinar para a pandemia COVID-19: um chamado para ação para as ciências da saúde mental. The Lancet Psychiatry, 2020.

KHATIB, Ahmed Sameer. Aulas por videoconferência: uma solução para o distanciamento social provocado pela COVID-19 ou um grande problema? 2020. Artigo. Disponível em: http://preprints.scielo.org/index.php/ scielo/preprint/view/787/1207. Acesso em: 12 set. 2021.

MARQUES, JOSÉ Roberto. O que é um transtorno emocional? Artigo disponível em: 〈https://www.ibccoaching.com.br/portal/>. Acesso em: 10.10.2021. 
OLIVEIRA, Maria Eveuma de.; CHAVES, Sergio Wellington Freire.; CHAVES, Ana Meire Freire. Caminhos e desafios do ensino remoto: uma realidade da escola profissionalizante no Estado do Ceará. Fortaleza: Imprece, 2021.

SANTOS, Laís Silveira. Dilemas morais da gestão pública brasileira no enfrentamento da pandemia do novo coronavírus. Revista de Administração Pública, Rio de Janeiro, 54(4):909-922, jul-ago. 2020.

SAVIANI, Demerval. Crise estrutural, conjuntural, nacional, coronavírus e educação o desmonte da educação nacional. Revista Exitus, v. 10, 2020. Disponível em: http://www.ufopa.edu.br/portaldeperiodicos/index. php/view/1463. Acesso em: 21.09.2021.

SCHORN, Solange Castro.; SEHN, Amanda Scöffel. Competências socioemocionais: reflexões sobre a educação escolar no contexto da pandemia. Disponível em: DOI: https://doi.org/10.1590/SciELOPreprints.2452〉. Acesso em: 30.09.2021. 


\section{IMPACTOS EMOCIONAIS NA PRÁTICA DOS DOCENTES: RECOMEÇAR E AVANÇAR EM TEMPOS DE PANDEMIA

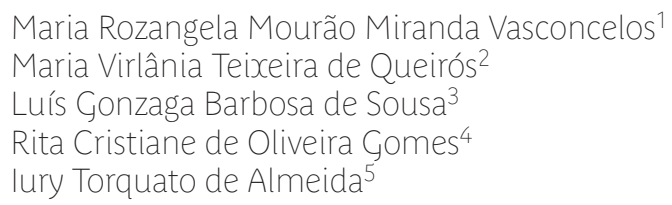

1 Especializanda do curso MBA em Gestão Educacional Pública e MBA Finanças e Gestão Pública e Privada da Faculdade Cesma Maracanaú (FACESMA). Especialista em Administração Escolar pela Fundação Universidade Estadual Vale do Acaraú. Licenciada em Formação de Professores do Ensino Fundamental (Licenciatura Plena) pela Universidade Estadual do Ceará.

E-mail: rozangelavasconcelos@gmail.com

2 Especializanda do curso MBA em Gestão Educacional Pública e MBA Finanças e Gestão Pública e Privada da Faculdade Cesma Maracanaú (FACESMA). Pós-Graduanda em Gestão Escolar pela FATENE Faculdade Tecnológica do Nordeste. Licenciada em Regime Especial pela Universidade Estadual Vale do Acaraú UVA, email: virlaniaqueiroz2020@gmail.com

3 Especializando do curso MBA em Gestão Educacional Pública e MBA Finanças e Gestão Pública e Privada da Faculdade Cesma Maracanaú (FACESMA), com Graduação em Geografia pela Universidade Federal do Ceará (UFC). Pós-graduação em Gestão Escolar pela Universidade Federal de Juiz de Fora (UFJF) e Pós-graduação em Planejamento Educacional pela Universidade Federal Fluminense (UFF), e-mail gbarbosa203@gmail.com

4 Especialista em Docência do Ensino Superior - Facesma; Gestão Escolar e Coordenação Pedagógica - Falc; Psicopedagogia Clínica, institucional e hospitalar - CETREDE; Gestão e Políticas Públicas - Fak. Graduada em Licenciatura Pedagogia - UVA; Professora da rede municipal de Maracanau há 33 anos e de Fortaleza há 20 anos; Atualmente Diretora Acadêmica da Faculdade Cesma de Maracanaú- FACESMA; E-mail: cristiane@facesma.com.br

5 Graduado em Administração - FAK; Licenciado em Pedagogia - FAK; Especialista em Gestão de Projetos - ABED; Especialista em Psicologia Organizacional e do Trabalho - FAK; Especialista em Gestão Escolar - FAESL; Especialista em Docência do Ensino Superior - FAK; Especialista em Gestão e Tutoria - UNIASSELVI; Mestre em Gestão de Negócios Turísticos - UECE; Doutor em Ciências da Educação - USC/PY; E-mail: iuryt.almeida@gmail.com 


\section{Considerações iniciais}

A pandemia veio para colocar as vísceras de fora do sistema educacional brasileiro, especialmente na educação pública onde as condições de trabalho da classe docente já eram muito deficitárias, e a considerar a situação de vulnerabilidade dos alunos atendidos prioritariamente pela rede pública de ensino se verifica que a situação que já era crítica se complicou, conforme aponta o site SAE Digital (2021, p. 1), ao destacar que: "[...] Outro problema... é a desigualdade social e de acesso a tecnologias, o que na área da Educação causa um abismo entre aqueles que podem dar continuidade ao seu processo de aprendizagem e outros que possuem nem sequer um dispositivo eletrônico com conexão à internet em casa". Como os professores estão na linha de frente do processo de ensino aprendizagem em qualquer rede de ensino se percebe a gravidade que este momento difícil da humanidade os impactou emocionalmente.

Nossa abordagem tem como foco principal mostrar como os trabalhadores da educação estão reestruturando sua prática docente e colocando no mais alto grau a sua criatividade para fazer frente a esta situação e proporcionando o máximo possível de aproveitamento aos nossos alunos, e como isso os afeta emocionalmente por se sentirem em muitos momentos impotentes diante de uma situação nunca experimentada em nossa época.

Em seguida trataremos da questão emocional onde apresentamos os desafios e possibilidades de trabalharmos as emoções como forças auxiliares ao nosso desempenho como profissionais e principalmente como cidadãos, para isso tomamos como material de 
referência o trabalho de Goleman (1995), "Inteligência Emocional", e o "Guia sobre competências socioemociocionais" que foi socializado pela Secretaria de Educação de Maracanaú com os coordenadores pedagógicos da rede municipal de ensino daquele município.

A parte experiencial tem como campo de pesquisa a realidade vivida no interior do Centro de Educação de Jovens e Adultos de Maracanaú (CEJAM), como seus docentes enfrentaram as situações didáticas com as aulas remotas, seus instrumentais de trabalho, formas didáticas e avaliativas, para isso contamos com projetos desenvolvidos pelos professores deste centro de educação com destaque para o projeto: "Ensino Remoto: recomeçar e avançar em tempos de pandemia", desenvolvido pelos professores Karla Silva e Yuri Monteiro.

A metodologia do estudo consiste em pesquisas bibliográficas, análise dos instrumentais utilizados na rotina da escola, de dados estatísticos fornecidos pela secretaria escolar, além de observações "in loco", discussões e redação.

Consideramos que o tema é de total relevância por mostrar a capacidade e a grandeza da classe docente em todos os níveis e modalidades, seu compromisso para com a educação, mesmo diante de uma realidade totalmente adversa e sem contar com as condições necessárias para enfrentar a problemática, seja diante da realidade estrutural-física da escola, seja da instabilidade emocional e da pobreza que domina os lares de grande parte de nossa gente.

\section{Sob o domínio da tecnociência}

A ação humana e seu modo de conceber a vida está na base da destruição do seu próprio habitat, daí a 
necessidade de se entender o paradigma tecnocrático na raiz da atual crise planetária, econômica, política, ética e social. A tecnologia pode melhorar a qualidade de vida das pessoas, criar coisas belas e dar condições para o desenvolvimento social, mas também pode ser usada como "máquinas de destruição".

Não há dúvidas que o paradigma tecnocrático orienta as práticas humanas em todas as esferas de sua ação, parece estar presente em tudo. O "homem" passa a ser o sujeito, e as outras coisas são todas objetificadas e manipuladas de acordo com seu interesse. Esta é uma concepção totalmente perniciosa, o ser humano passa a explorar desmedidamente os recursos naturais provocando seu esgotamento, o que compromete a existência da própria vida sobre à terra. O perigo é iminente, "vivemos em uma sociedade de consumidores... que reforça a escolha de um estilo de vida e uma estratégia existencial consumista, e rejeita todas as opções culturais alternativas" (BALMAN, 2008).

A lógica desse paradigma é a exploração e o domínio, e parece que nada escapa dessa ordem, inclusive a humanidade, em todos os seus aspectos. O lucro, o levar vantagem em tudo, a exploração tem a primazia absoluta. E ainda se utiliza da ideologização ao afirmar que a saída para todos os problemas estão na própria lógica:

Não se concebe pensar que seja possível sustentar outro paradigma cultural e servir- se da técnica como instrumento, porque hoje o paradigma tecnocrático tornou-se tão dominante que é muito difícil prescindir dos seus recursos sem ser dominado pela sua lógica (LS 108).

Não se percebe que as mazelas do mundo como a fome, a miséria e os desequilíbrios ambientais es- 
tão todos entrelaçados intimamente com este modelo de crescimento tecnológico e econômico. Vivemos um novo tempo onde tudo parece relativizado, neste a preponderância da tecnociência é inquestionável, sua hegemonia autoritária não encontra limites e tem suas bases na economia, mas atinge todos os campos das relações humanas incluindo afetos e emoções.

Tudo está interligado, uma sociedade que despreza e explora os mais pobres, discrimina os vulneráveis e desrespeita a vida em sua essência não tem como prosperar, está condenada ao fracasso, a técnica por si só não consegue resolver essa tão delicada questão: "[...], aliás, quando a técnica ignora os grandes princípios éticos, acaba por considerar legítima qualquer prática" (LS 136). O modo de produção capitalista, viabilizado pela tecnociência, é o responsável pela relativização de tudo mais que o cerca.

O problema das desigualdades sociais, que estão no centro da discussão, se constituindo como fator determinante para o desempenho do educando nesse período pandêmico é um reflexo da conjuntura atual de nossa sociedade e tem dimensões mundiais. A pandemia serviu para colocar às claras esta situação, os estudantes pobres estão sofrendo muito mais com o ensino remoto porque suas condições econômicas não lhes permitem acompanhar adequadamente as aulas. É notório que vivemos em uma sociedade globalizada que privatiza a riqueza e socializar a miséria, segundo Oliveira (2016), ao afirmar que:

Recorre-se à lógica da globalização para legitimar o desmantelo das instituições de proteção social e de controle de mercados, do exercício do papel equilibrador de Estado e da proteção dos 
direitos dos cidadãos. Grandes massas de indivíduos são os perdedores desse processo (OLIVEIRA, 2016, p. 137).

Os mais humildes pagam as contas mais altas, é a lógica do absurdo, temos um crescimento econômico não acompanhado pelo desenvolvimento humano. A tecnociência trouxe muitos avanços para a humanidade, mas esta continua tão ou mais excludente quanto era antes do advento da modernidade, é uma realidade de profundo desequilíbrio onde o próprio modelo dominante se apresenta como moribundo mais ainda persistente em sua ação e cada vez mais voraz.

\section{Centro de EJA de Maracanaú, adaptando-se ao um novo tempo}

O Centro de Educação de Jovens e Adultos de Maracanaú (CEJAM) é uma instituição de ensino que trabalha exclusivamente com a modalidade da EJA semipresencial (6.o ao 9.o e Ensino Médio), contemplando um público-alvo de jovens e adultos que por diversos motivos não concluíram seus estudos na idade certa. E em tempos de pandemia onde jamais imaginávamos que iríamos passar, os desafios foram diversos para que os educandos não fossem prejudicados.

Sendo assim, tendo uma equipe muito comprometida com a função social que o CEJAM exerce na vida desses alunos, o grupo gestor juntamente ao corpo docente, elaboraram um Plano de Ação para realizarem as atividades e provas no ensino remoto, utilizando recursos tecnológicos e as redes sociais (WhatsApp, facebook). Planejamos e passamos a executar um panorama de fluxo bem organizado, padronizando o aten- 
dimento incluindo desde a abordagem inicial através de: informativos, mensagens após atividades e provas realizadas pelo google meet e google forms, além do acompanhamento e controle das provas, no drive institucional da escola, whakshops com os professores, gestão e outros.

\section{A importância da EJA no cenário educacional do Brasil}

No Brasil, as desigualdades sociais são gritantes. Vivemos em um País onde a má distribuição de renda afeta a maior parcela da população. A conclusão é do relatório de desenvolvimento do Banco Mundial. Segundo esses dados, $51,8 \%$ de toda a renda no país está concentrada nas mãos de apenas $10 \%$ da população, enquanto os $2.0 \%$ mais pobres, que detêm a força do trabalho, dividem apenas $21 \%$ da renda nacional.

Em Maracanaú, a realidade não é muito diferente, apesar de sediar o maior Parque industrial do Estado, paradoxalmente possui um dos maiores conjuntos habitacionais populares, onde residem um grande número de desempregados e de pessoas sem formação escolar Fundamental ou Superior, presas fáceis para a exploração do trabalho. O Centro de Educação de Jovens e Adultos de Maracanaú está seguramente respondendo a esta demanda social, pois um grande número de pessoas procura esta escola para continuar seus estudos, para conquistar o primeiro emprego ou melhorar seu perfil financeiro.

Daí se faz necessário buscar uma Pedagogia Progressista numa concepção libertadora, onde seja contemplado tanto o aspecto das exigências do mercado 
de trabalho quanto uma visão crítica do mundo, especialmente o do trabalho, que possibilite ao educando (jovens e adultos) adquirir uma consciência crítica da estrutura socioeconômica do momento. Diferente da criança, que será o "futuro" de uma nação, os jovens e adultos são a força de trabalho do presente.

Nas novas regras da globalização, novos comportamentos sociais são determinantes para atender a grande competitividade e rotatividade no trabalho. Repensar a educação nos leva a sair de um paradigma ultrapassado para os ditames urgentes da globalização. O Referencial compreende o tipo de sociedade e população onde a escola está inserida bem como a educação que a escola julga apta a oferecer. Segundo Freire (1997, p. 27): “[...] Educar não significa apenas transmitir conhecimento. O processo de educação se constrói verdadeiramente através do diálogo permanente entre professores e alunos e entre ambos".

A Educação de Jovens e Adultos atende a um público não convencional, que faz parte de uma demanda peculiar, com características específicas, que o diferencia do aluno que teve acesso à escola na idade própria. Como ferramenta para melhorar a qualidade e competitividade no setor produtivo, ampliar as condições de empregabilidade do trabalhador e fortalecer a cidadania, ganha particular importância a escolaridade de jovens e adultos no município de Maracanaú, aliada à oferta de cursos profissionalizantes.

Anteriormente conhecida como supletivo, a atual EJA traz consigo a concepção de inclusão social. No contexto cearense, a oferta nos anos finais do ensino fundamental ocorre nos formatos presenciais, na maioria das escolas, e semipresencial nos Centros de Educa- 
ção de Jovens e Adultos (CEJA). É ofertada em diferentes contextos: urbanos, rurais, comunidades indígenas, quilombolas, em situação de privação de liberdade, entre outros.

Dessa forma, o projeto curricular da EJA considera, regra geral, os componentes curriculares estabelecidos na Base Nacional Comum Curricular (BNCC, 2017), devendo atender às características e necessidades dos grupos sociais que buscam a modalidade para retornar à escola ou iniciar seus estudos. Deve ser, portanto, flexível para respeitar as experiências e identidades culturais dessas pessoas, possibilitando o fortalecimento da autonomia no seu processo de aprendizagem e colaborando para o exercício de sua cidadania. É essencial que a ação curricular integre os conhecimentos ensinados, à realidade dos alunos, garantindo uma contextualização que torne significativo o processo de ensinar e aprender. Ademais, a instituição que desenvolve a EJA precisa ter como característica de sua identidade, a natureza indenitária de seus alunos. Precisa, efetivamente, ser uma escola para jovens e adultos, reconhecendo e utilizando a seu favor a experiência e maturidade dos estudantes.

A Educação de Jovens e Adultos com a homologação da BNCC, documento contemporâneo que estabelece objetivamente o conjunto de aprendizagens necessárias e indispensáveis a todos, o Brasil inicia uma nova etapa em sua história educacional buscando alinhar o seu sistema de educação aos melhores do mundo.

A BNCC ratifica o compromisso do Estado Brasileiro em promover a elevação da qualidade do ensino ofertado, garantindo o acesso a conhecimentos, competências e habilidades essenciais a todos. Diante dessas 
funções podemos concluir que a EJA visa minimizar o abismo cultural e social entre os estudantes brasileiros jovens ou adultos, contribuindo para a construção de uma sociedade mais justa, democrática, equitativa, solidária e com menos desigualdade social.

Nesse sentido, a BNCC em suas competências gerais evidencia termos que as funções da EJA buscam superar através de suas ações. Por isso destaca-se, no ensino da EJA, a importância da valorização dos conhecimentos historicamente construídos sobre o mundo físico, social, cultural e digital. O exercício da curiosidade intelectual, a valorização e o fluir das manifestações artísticas e culturais, a utilização das diferentes linguagens, a valorização da diversidade de saberes e vivências culturais, a argumentação com base em fatos, dados e informações.

É fundamental conhecer-se, apreciar-se e cuidar de sua saúde física e emocional, exercitar a empatia, o diálogo, a resolução de conflitos e a cooperação, e por fim o agir pessoal e coletivamente, com autonomia, responsabilidade, flexibilidade, resiliência e determinação. A Base não aponta Unidades Temáticas, Objetos de Conhecimentos ou Habilidades específicas para a modalidade EJA. Entende-se dessa forma que, os direitos de aprendizagem devem estar garantidos para a Educação Básica, para toda e qualquer modalidade de ensino.

Nesse sentido, cabe aos docentes dessa modalidade, com o suporte do coordenador pedagógico da escola, uma apropriação das competências gerais da educação básica, bem como das competências específicas de cada componente curricular, com fins de favorecer a transposição didática de cada objeto de aprendizagem, estratégia imprescindível para o desenvolvimento de 
atitudes, de valores e de habilidades necessárias para o exercício da cidadania.

Atualmente, estamos sob a égide de uma nova Lei de Diretrizes e Bases da Educação Nacional (LDB n.o 9.394/96) (BRASIL, 1996), onde, dentre outros aspectos, traz um conceito mais abrangente sobre a educação; a vinculação da educação com o mundo do trabalho e com as diferentes práticas sociais; as exigências de padrões básicos de qualidade do ensino; pluralidade de formas de acesso aos diversos níveis de modalidade de ensino, para ensejar o cumprimento da sua obrigatoriedade; a busca de construção da identidade do ensino médio; a reconfiguração de toda base curricular, tendo como foco o aluno nas suas diferenças individuais e valorizando a experiência extraescolar, que abrange espaços significativos de articulação escola comunidade.

\section{Perfil do Educador da EJA}

A Educação de Jovens e Adultos é um desafio para o educador, haja vista suas características e a sua diversidade. Com uma metodologia diferenciada que busca preservar o desenvolvimento e a iniciativa de cada um dos aprendizes, de forma mais humana e eficaz, torna o exercício da profissão de educador da EJA, muito mais abrangente do que a que está posto na educação tradicional.

O educador que se propõe a trabalhar na Educação de Jovens e Adultos, mais precisamente neste centro de educação, deve demonstrar a importância prática do assunto a ser estudado, como também transmitir o entusiasmo pelo aprendizado e a projeção de que aquele conhecimento fará diferença em suas vidas da escola.

Pensando na forma construtiva de educação, a EJA procura habilitar seus educadores com a disposi- 
ção de trabalhar com seus alunos, conteúdos significativos, isto é, que sejam verdadeiramente pertencentes ao cotidiano ou que possam ser relacionados às suas experiências, como pensou o "pai” da EJA Freire (1979):

[...] Quando o homem compreender sua realidade, pode levantar hipóteses sobre o desafio dessa realidade e procurar soluções. Assim pode transformá-la e com o seu trabalho pode criar um profundo próprio, seu eu e suas circunferências (FREIRE, 1979, p.84).

Para saber enfrentar a realidade é preciso que o homem passe a perceber o mundo com uma visão crítica, uma mudança de percepção, na forma de ver o mundo. Buscamos, portanto, um professor/criador com uma visão crítica social, na perspectiva de praticar uma educação transformadora. Toda teoria progressista libertadora tem como passaporte, a prática formar um novo homem, sujeito de seu conhecimento, um conhecimento articulado com a realidade, as necessidades e possibilidades de mudanças.

O caminho para haver mudanças é através da educação, mas uma educação libertadora, questionadora dos problemas sociais, onde o aluno sinta-se responsável pelas mudanças requeridas pela sociedade da qual faz parte. Não devemos ancorar neste dilema: "Somos país de terceiro mundo porque temos uma educação falha ou nossa educação é falha porque somos de terceiro mundo"?

\section{Considerações finais}

Por todos os aspectos vivenciados pelos docentes, discentes e comunidade escolar no período de pandemia mencionados anteriormente e ainda considerando os impactos emocionais pelos quais eles passaram. Per- 
cebe-se que adaptações em seus cotidianos tiveram que acontecer.

Acreditamos que os desafios foram superados com bastante maestria. Contudo, precisamos fortalecer os desafios já superados e buscar soluções para os que surgem no decorrer do processo ensino- aprendizagem. Docentes necessitam cuidar do seu emocional para poder cuidar do outro.

Dessa forma, toda a escola continua se reinventando e buscando adaptar sua prática para prover um ensino de qualidade.

\section{Referências}

BAUMAN, Zygmunt. Vida para consumo: a transformação das pessoas em mercadoria. Rio de Janeiro: Zahar, 2008.

BRASIL/MEC. Lei no. 9.394, de 20 de dezembro de 1996. Lei de Diretrizes e Bases da Educação Nacional. Brasília, DF: 20 de dezembro de 1996.

. Base Nacional Comum Curricular (BNCC). Educação é a Base. Brasília, MEC/CONSED/UNDIME, 2017.

FREIRE, Paulo. Educação e mudança. 15. ed. Rio de Janeiro: Paz e Terra, 1979.

. Pedagogia do Oprimido. 24. ed. Rio de Janeiro: Paz e Terra, 1997. GOLEMAN, D. Inteligência Emocional. 82. ed. Rio de Janeiro: Objetiva, 1995.

HTTPS://sae.digital/educacao-e-coronavirus-quais são os impactos da pandemia? Acesso em 23/07/2021.

OLIVEIRA, Manfredo Araújo de. O paradigma tecnocrático. In: MURAD, A.; TAVARES, S. S. Cuidar da casa comum. São Paulo: Paulinas, 2016, p. 129-145.

PAPA FRANCISCO. Carta Encíclica Laudato Si'- sobre o cuidado da casa comum. São Paulo: Paulinas, 2015. 


\title{
OS DESAFIOS DOCENTES NO ENSINO REMOTO EM TEMPOS DE ISOLAMENTO SOCIAL SOB O OLHAR DA GESTÃO
}

\author{
Antônia Wilma de Oliveira Andrade Santos ${ }^{1}$ \\ Francisca Esmênia de Souza Teixeira² \\ Káthia Cyléa Meneses Oliveira ${ }^{3}$ \\ Luciana Mascena Silva ${ }^{4}$
}

\section{Considerações iniciais}

\section{O fazer docente pode ser concebido como uma prá- tica em constante movimento, porém, nunca completo}

1 Licenciada em Pedagogia (Licenciatura Plena) pela Universidade Estadual Vale do Acaraú (UVA), Especialização em Metodologia do Ensino Fundamental e Médio (UVA), Especialização em Gestão Escolar pela Universidade Federal do Ceará (UFC). Atualmente é professora da rede pública da Prefeitura Municipal de Maracanaú-Ce, na função de Gestora Geral da EMEIEF Profa Francisca Florência da Silva de 2017 a 2022.

E-mail: wilmaandradeoliveira@hotmail.com

2 Licenciada em Pedagogia em Regime Especial pela Universidade Estadual Vale do Acaraú - UVA (2003), Especialização em Psicopedagogia Institucional e Clínica pela Universidade Estadual Vale do Acaraú - UVA (2003), Especialização em Informática Educativa pela Faculdade de Carapicuíba - FALC (2014), Especialização em Gestão Escolar Área de Conhecimento Ciências Humanas pela Universidade Federal do Ceará - UFC (2016), Mestrado em Ciências da Educação pela Universidade Interamericana (2015) e Doutoranda em Ciências da Educação pela Universidade Interamericana. Atualmente é professora da rede pública da Prefeitura Municipal de Maracanaú-Ce, e Coordenadora Administrativo Financeira da EMEIEF Profa Francisca Florência da Silva de 2013 a 2021; E-mail: franciscaesmeniadesouza@gmail.com

3 Graduada em Pedagogia- Ens Fundamental 1 (UECE); Especialização em Psicopedagogia Clínica e Institucional (UVA); Especialização em Administração Escolar( UVA); Professora efetiva da Prefeitura de Maracanaú; E-mail kathiacylea@gmail.com

4 Graduada em Biologia - UVA; Especialista em Auditoria ambiental - CENTEC; Mestra em Ciências Morfofuncionais - UFC;

E-mail: lumascena2@gmail.com 
e acabado, pois tendo em vista seus inúmeros desafios para responder às demandas que lhe são impostas, necessita ser repensado e questionado cotidianamente.

Nesse sentido, o artigo em questão, cujo tema aborda os desafios docentes no ensino remoto em tempos de isolamento social sob o olhar da gestão, tem a intenção de explanar algumas reflexões acerca dessa prática docente, improvisada em seu ambiente residencial, e no uso que fazem dos suportes tecnológicos que se encontram à sua disposição, sobretudo, pois aos mesmos são novamente definidas as relações entre o conhecimento a ser ensinado, reinventando-se diariamente, como a finalidade de variar estratégias e utilizar novos recursos para atender a demanda de suas aulas e garantir uma aprendizagem satisfatória aos discentes.

Nesse processo, encontra-se a gestão escolar, seja no âmbito pedagógico ou administrativo, para mediar essas ações, nesses tempos de ensino remoto, com suporte nas atividades curriculares e extracurriculares, com a elaboração e execução de projetos, atividades colaborativas, comunicação constante entre alunos, professores, pais e escola.

Nesse entendimento, constata-se um novo formato de prática docente despontando, onde o quadro, o giz e os livros não são mais considerados como únicos instrumentos para desenvolver a aprendizagem, pois de modo virtual, o Ensino Remoto Emergencial (ERE), surgido nesses novos tempos de isolamento social, vem exigindo novas adequações e novos modelos de ensino.

Isso posto, a ideia de abordar esse tema, partiu das perspectivas de um olhar da gestão sobre esses novos desafios docentes, entre tantos outros, visto que os recursos tecnológicos já fazem parte do cotidiano 
educacional, ainda que haja resistência por parte dos mesmos para essa prática e pouco suporte técnico para que a comunidade discente possa usufruir desse aparato. Esse novo conceito de ensino remoto emergencial, trouxe-nos o desafio de repensar novas estratégias pedagógicas e buscar práticas didáticas oriundas da cultura digital, levando-nos a refletir sobre como esses profissionais estão lidando com essas inovações?

Nesses termos, o objetivo do estudo é analisar o olhar da gestão sobre os desafios docentes no ensino remoto em tempos de isolamento social, mas especificamente, delinear os termos do ensino remoto e isolamento social, bem como destacar a visão dos gestores sobre essa experiência didática de forma articulada e desafiadora.

Desse modo, o estudo foi desenvolvido a partir das análises teóricas de Khatib (2020), Moran (2015), Réginier e Arroio (2019), Silva e Coêlho (2021), entre outros especialistas que tratam do assunto. $O$ procedimento metodológico de abordagem qualitativa de natureza teórica descritiva caracterizou-se por uma revisão bibliográfica em obras ligadas ao assunto, desenvolvida com base em material já elaborado, constituído principalmente de livros, periódicos e artigos científicos.

Assim sendo, a partir desta introdução, este artigo dar ênfase no desenvolvimento do estudo ao quadro de isolamento, distanciamento social e o ensino remoto em tempos de pandemia e os desafios docentes nas adaptações para que o ensino-aprendizagem discente aconteça, posteriormente, apresentamos as considerações finais e os referenciais utilizados. 


\section{Quadro de isolamento, distanciamento social e o ensino remoto em tempos de pandemia}

A partir da situação de emergência deflagrada pela pandemia causada pela Covid-19, no ano de 2020, o cenário educacional passou por inúmeras transformações, uma delas foi um novo modelo de ensino, ou seja, o Ensino Remoto Emergencial (ERE) determinando que os sistemas institucionais e os professores se articularem e, consequentemente, migrassem para essa modalidade de ensino, ofertando aos estudantes cobertura para sua aprendizagem.

Todavia, dentre tantas constatações e informações sobre a temática, ao adentrar no assunto, cabe antecipadamente, explanar ainda que de forma sucinta, os termos isolamento e distanciamento social, para podermos compreender as dificuldades diárias enfrentadas pelos professores para que sua prática pedagógica aconteça.

O termo isolamento tem sua significância no dicionário, ao expressar "[...] s.m. Ação ou efeito de isolar, de separar dos demais; separação. Estado de uma coisa ou de uma pessoa isolada, distanciada, entre outros [...]" (FERREIRA, 2009, p. 434). Já, o distanciamento social traz seu significado sob diversos aspectos, sobretudo, quando ocorre de forma involuntária, por ordem expressa governamental, visando evitar a proliferação de doenças em épocas pandêmicas.

Assim, de acordo com dados do Ministério da Saúde, Portaria n.o 356, de 11 de março de 2020 (BRASIL, 2020), por distanciamento social entende-se:

[...] a diminuição de interação entre as pessoas de uma comunidade para diminuir a velocidade de transmissão do vírus. É uma estratégia impor- 
tante quando há indivíduos já infectados, mas ainda assintomáticos ou oligossintomáticos, que não se sabem portadores da doença e não estão em isolamento (BRASIL, 2020, p. 1).

Nesse caso, no Brasil, para evitar a disseminação do vírus, o governo decretou medidas preventivas para que as pessoas evitarem, aglomerações, suspendendo a realização de grandes eventos, atividades escolares e econômicas, entre outras, solicitando à população para ficarem o máximo possível em casa, mantendo-se uma distância segura umas das outras.

Alguns países determinaram o fechamento de empresas e que os setores não essenciais fechassem suas portas e os cidadãos se recolhessem em suas casas. Khatib (2021, p. 4), revelou que além do Brasil “[...] em 13 de março de 2020, 61 países na África, Ásia, Europa, Oriente Médio, América do Norte e América do Sul anunciaram ou implementaram o fechamento de escolas e universidades".

Com base nessa determinação, conforme evidenciados por Matos e Costa (2020), foi dada a indicação de suspender todas as atividades letivas presenciais e repensar e reprogramar o restante do ano letivo, no sentido de manutenção e concretização das aprendizagens possíveis discentes e conclusão, com menor impacto possível, os percursos escolares.

Diante do contexto exposto, percebe-se a importância de um espaço já conhecido, mas ainda pouco dominado por muitos docentes, ou seja, o "espaço virtual”, conhecido também por "ensino à distância”. A esse respeito, expõem Cabero-Almenara et al (2019, p. 25) que,

[...] o ensino virtual tem se tornado uma abordagem amplamente utilizada no âmbito do ensino 
superior, tanto em sua aplicação completa por meio do e-learning como combinada com o ensino presencial e o b-learning, reconhecendo nesta modalidade várias virtudes como flexibilidade, descentralização, interatividade, entre outras.

Já, o ensino à distância, segundo Costa (2020), há o apoio de tutores, não dependendo de um tempo/horário pré-estabelecido e a carga horária é partilhada, ou seja,

"[...] nos mais diversificados recursos midiáticos de interação que compõem atividades síncronas e assíncronas e com encontros presenciais, obrigatórios, somente para avaliações e práticas". "Mesmo sem a presença, existe um processo de interação na modalidade em que tutores podem sanar dúvidas através de Ambientes Virtuais de Aprendizagem" (AVA) (COSTA, 2020, n.p. in: BARBOSA; ALMEIDA, 2021, p. 127).

Complementando essas informações, segundo Cordeiro (2021), o Ministério da Educação, considera que essa modalidade educacional (ensino à distância) onde alunos e professores estão separados física ou temporalmente por isso, faz-se necessária a utilização de meios e tecnologias de informação e comunicação. Essa modalidade é regulada por uma legislação específica e pode ser implantada na educação básica e na educação superior.

Por sua vez, o termo remoto, refere-se ao distanciamento geográfico entre as pessoas, segundo Dutra (2021), distante no espaço, mas perto pelas redes digitais, mediados e informados pela conectividade para evitar a disseminação do vírus, ainda ressaltando que:

O termo "remoto" significa distante no espaço e se refere a um distanciamento geográfico. $O$ en- 
sino é considerado remoto porque os professores e alunos estão impedidos por decreto de frequentarem instituições educacionais para evitar a disseminação do vírus. É emergencial porque do dia para noite o planejamento pedagógico para o ano letivo de 2020 teve que ser engavetado (DUTRA, 2021, p. 1).

Nesse sentido, complementando a concepção do autor, foi preciso repensar em atividades pedagógicas mediadas pelo uso da internet, para efetivar a aprendizagem discente, aplicadas então, em função das restrições impostas pela pandemia para minimizar os impactos na aprendizagem advindos do ensino presencial, visto que o currículo da maior parte das instituições educacionais não foi criado para ser aplicado remotamente (DUTRA, 2021).

Sendo assim, foi necessário nesse período, que as instituições educacionais redirecionaram sua prática para o Ensino Remoto Emergencial (ERE) objetivando ofertar cobertura aos seus estudantes, que continuavam em confinamento domiciliar.

Nesse sentido, para Costa (2020), o Ensino Remoto Emergencial se encontra em efetiva realização na atualidade, no Brasil, assemelhando-se a Ensino à Distância (EAD) apenas no que se refere a uma educação mediada pela tecnologia. Mas os princípios seguem sendo os mesmos da educação presencial. As aulas remotas, estas são em tempo real e no mesmo horário que as presenciais, com as mesmas disciplinas, a interação é diária com o professor, o calendário é próprio conforme o Plano de ensino adaptado para a situação emergencial. Conforme a Portaria n.o 343 de 17 de março de 2020, o MEC dispõe a substituição das aulas pre- 
senciais por aulas em meio digitais enquanto durar a situação de pandemia do COVID-19.

Neste aspecto todos os meios tecnológicos como internet, mídias digitais, celulares, smartphones, televisão, são fundamentais neste processo (MEC, 2020). Esses recursos didáticos serão abordados na seção a seguir, acerca dos desafios docentes nas adaptações para que o ensino-aprendizagem discente aconteça.

\section{Os desafios docentes nas adaptações para que o ensino-aprendizagem discente aconteça}

Reportando-se aos desafios docentes nestes tempos de pandemia, pode-se considerar que a utilização das ferramentas tecnológicas, ou seja, os recursos didáticos como internet, mídias digitais, celulares, smartphones, televisão, computadores, chromebooks, entre outros, como estratégia pedagógica, é relevante, pois cabe ao professor da sala de informática planejar e ministrar com o professor regente as atividades pedagógicas a serem desenvolvidas, para fins educacionais.

Nesse sentido, Oliveira e Moura (2021) relatam que a ideia de se fazer educação com uso de novas tecnologias é algo cada vez mais presente no cotidiano docente, acrescentando ainda:

O professor pode lançar mão dessa disposição digital para aperfeiçoar processos de ensino e aprendizagem. Ao fazê-lo, ele contempla atitudes cognitivas e modos de pensamento que se desenvolvem juntamente com o crescimento da cibercultura, ou seja, contempla o novo espectador, a geração "net" (OLIVEIRA; MOURA, 2021, p. 65).

Portanto, o acesso à internet e a utilização das redes sociais possibilita a continuação das aulas neste 
período de ensino remoto emergencial. Assim sendo, a frequência com que docentes e alunos utilizam as redes foi observado por Oliveira e Moura (2021), que há uma utilização bem acentuada, principalmente neste período de pandemia onde professores precisam usar de criatividade para manter o foco dos alunos nos conteúdos, num mundo de opções atraentes existentes nas redes sociais, alguns docentes excedem o tempo de suas aulas para interagir com seus alunos, tirando dúvidas, repassando atividades atrasadas, fazendo recuperação paralela.

A esse respeito, para Getschko (2016), o isolamento social nos obrigou a usar a internet de uma forma absurdamente inusitada em todos os setores, bem como as tecnologias, no caso, a internet tem sido utilizada nas atividades pedagógicas, pelos professores, tornando as aulas mais dinâmicas e transformadoras.

Cabe ainda acrescentar, os imensos desafios, relatados por Silva e Coêlho (2021), ao apontar que um dos fatores mais impactantes representa a falta de acesso por parte da população discente aos equipamentos e internet de qualidade, para poderem recorrer às ferramentas indicadas pela escola. Outro fator a ser considerado é a falta de habilidade e domínio docente para essa utilização, tendo em vista, a mínima formação, ou mesmos os poucos recursos disponíveis para que essa formação aconteça.

Dessa forma, segundo relatos de Getschko (2016), como as tecnologias são utilizadas nas atividades pedagógicas, fazem com que possamos refletir sobre a necessidade de mais formações continuadas desses profissionais, com cursos que aliado ao uso das Tecnologias Digitais da Informação e Comunicação (TDIC), 
tornando-se forte parceira na preparação das aulas, impulsionado, portanto, a utilização da internet por um maior período.

Enfim, como os recursos didáticos são escolhidos pelos docentes em sala de aula é de suma importância para o processo de ensino/aprendizagem, pois sendo esses recursos adequados às suas aulas, representam facilitadores capazes de tornar o ensino mais dinâmico, enriquecendo a vivência diária dos educadores e educandos, quando as TDIC são empregadas como facilitadora desse processo de ensino, torna-se evidente o interesse dos alunos, fazem parte do seu cotidiano, o que instiga o interesse de manusear essas ferramentas para aprender o conteúdo ministrado pelo professor (GETSCHKO, 2016).

A utilização das redes sociais pelos professores da escola serve para aprimorar a interação com seus alunos. Consequentemente o educando também se sentirá importante por participar desse processo de aprendizagem, onde o aluno por ter habilidade, ajuda o professor nesse processo de aplicação das aulas (BARBOSA; ALMEIDA, 2020).

Nesse processo, com base nos citados autores, podemos sintetizar a valiosa percepção gestora, quanto a utilização dessas ferramentas e as redes sociais partilhadas por professores e alunos, pois muito mais do que um despertar de curiosidade e interação entre as partes, quando são usadas de maneira proveitosa, possibilitam um melhor aproveitamento do tempo, visto que o aluno se torna protagonista do ensino-aprendizagem junto ao professor.

Nessa concepção, Barbosa e Almeida (2020), justificam a importância dessas interações, ao ressaltar 
que ao reconhecer a realidade atual, provocada pela COVID-19, percebe-se que, por não haver presença física, entre os participantes de uma aula remota emergencial, os métodos de interação precisam ser atrativos, colaborativos e, sobretudo, para superar as distâncias físicas.

\section{Considerações finais}

Considerando os objetivos de estudo almejados, podemos refletir acerca dos desafios docentes no ensino remoto em tempos de isolamento social sob o olhar da gestão que os percalços que se tornaram parte da educação neste período de ensino remoto emergencial, foram imensos, tendo em vista as dificuldades que os docentes tiveram para se reinventar no sentido de buscar formação para utilizar as tecnologias digitais em suas aulas, desafio esses de ordem tecnológica e humana.

Os docentes tiveram que retornar às salas de aulas, em tempos de isolamento social e ensino remoto emergencial, aprendendo em tempo recorde a utilizar os recursos tecnológicos como ferramenta em suas aulas, e assim, muitos tiveram que vencer a resistência à tecnologia, pois estas passaram a ser a única opção de promover aulas e assim conseguir alcançar seus alunos, gerando buscas por inúmeros recursos didáticos para que os mesmos pudessem ter seu aprendizado continuado.

Todavia, dos resultados positivos ou negativos alcançados podemos destacar haver imensa necessidade de um olhar da gestão, quanto a preparação para adequação do tempo pedagógico de trabalho às limitações no uso das TDIC nas estratégias das aulas remotas.

Outro aspecto considerado é a precariedade dos equipamentos utilizados pelos estudantes, exigindo ao 
professor a redução do nível tecnológico das atividades, muitas vezes se limitando ao uso de arquivo em PDF ou foto da atividade, pois a maior parte da turma não possui um processador adequado em seus aparelhos, ou memória no celular para abrir arquivos, links e vídeos que exigem mais velocidade e espaço de memória das mídias digitais. Soma-se a isso, muitos alunos não conseguem utilizar os equipamentos de forma pedagógica e apresentam grande dependência do professor para acompanhamento do processo remoto.

\section{Referências}

BARBOSA, Silvia Danizete Pereira.; ALMEIDA, Daiane Vithoft de. O ensino remoto emergencial: mediação tecnológica e estratégias de ensino-aprendizagem. Caderno Intersaberes, v. 9, no 22, p.123-136, Centro Universitário Internacional Uninter, 2021.

BRASIL, Ministério da Saúde. Portaria no 356, de 11 de março de 2020. Dispõe sobre a regulamentação e operacionalização do disposto na Lei no 13.979, de 6 de fevereiro de 2020, que estabelece as medidas para enfrentamento da emergência de saúde pública de importância internacional decorrente do coronavírus (COVID-19). Diário Oficial da União, Brasília, DF, ed. 49, seção 1, p. 185, 12 Mar 2020.

Ministério da Saúde. O que é COVID-19. 2020. Disponível em: https://coronavirus.saude.gov.br/sobre-a-doenca. Acesso em: 16 set. 2021.

CABERO-ALMENARA, Julio; ARANCIBIA, Maria Luisa; PRETE, Annachiara del. Conhecimento Técnico e Didático do Moodle LMS no Ensino Superior. Além do uso funcional. Jornal de novas abordagens em pesquisa educacional, v. 8, n. 1, pág. 25-33, 2019. 
CORDEIRO, Karolina Maria de Araújo. O impacto da pandemia na educação: a utilização da tecnologia como ferramenta de ensino. Disponível em: http://idaam.siteworks.com.br/>. Acesso em: 13 set. 2021.

DUTRA, Flávio. O Ensino Remoto Emergencial e a Educação a Distância. Disponível em: https://www.ufrgs. br/coronavirus/base/artigo-o-ensino-remoto-emergencial-e-a-educacao-a-distancia/por Patricia Alejandra Behar, 06 jul. 2020. Universidade Federal do Rio Grande do Sul. Acesso em: 17 set. 2021.

COSTA, Renata. Educação remota emergencial X EaD: desafios e oportunidades. Linkedin, 05 abr. 2020. Disponível em: 〈ttps://www.linkedin.com/pulse/educacao-remota-emergencial-x-ead-desafios-e-renata-costa〉 Acesso em: 19 jul. 2020.

FERREIRA, Aurélio Buarque de Holanda. Novo Aurélio Século XXI: o dicionário da língua portuguesa. 3. ed. Rio de Janeiro, Nova Fronteira, 2009.

GETSCHKO, Demi. (Org.). Núcleo de Informação e coordenação do Ponto BR. Educação e tecnologias no Brasil [livro eletrônico]: um estudo de caso longitudinal sobre o uso das tecnologias de informação e comunicação em 12 escolas públicas/Núcleo de Informação e coordenação do Ponto BR. 1. ed. São Paulo: Comitê Gestor da Internet no Brasil, 2016.

KHATIB, Ahmed Sameer. Aulas por videoconferência: uma solução para o distanciamento social provocado pela COVID-19 ou um grande problema? 2020. Artigo. Disponível em: http://preprints.scielo.org/index.php/ scielo/preprint/view/787/1207. Acesso em: 12 set. 2021.

MATOS, Filomena Adelaide de; COSTA, Emília. Aprendizagem e relação interpessoal no ensino à distância em Enfermagem: relato em tempo de pandemia. Revista Docência do Ensino Superior, Belo Horizonte, v. 10, e024719, p. 1-18, 2020. 
MORAN, José Manuel. Educação híbrida: um conceito-chave para a educação, hoje. In: BACICH, Lilian; NETO, Adolfo Tanzi; TREVISANI; Fernando de Mello (org.). Ensino Híbrido: Personalização e Tecnologia na Educação. Porto Alegre: Penso, 2015.

OLIVEIRA, Cláudio de.; MOURA, Samuel Pedrosa. TIC'S na educação: a utilização das tecnologias da informação e comunicação na aprendizagem do aluno. Curso de Pedagogia da UESPI-Campus Dom José Vásquez Díaz. 2015, p.75-94. Disponível em: 〈http://periodicos. pucminas.brarticle Acesso em: 10 set.2021.

SILVA, Maria Eliene Magalhães.; COÊLHO, Raimunda de Fátima Neves (Orgs). Educação e saúde para igualdade em relatos de experiências e pesquisas na pandemia: foco na educação especial, EJA, indígena, quilombola, básica e superior. Fortaleza: Imprece, 2021. 
INTELIGÊNCIA EMOCIONAL: EXPERIÊNCIAS EXITOSAS DE PROFISSIONAIS DA EDUCAÇÃO, SUPERANDO OS MEDOS E AS EXPECTATIVAS ENTRE QUEM ENSINA E QUEM APRENDE NO PERÍODO PANDÊMICO

\author{
Andréa Leal Dias ${ }^{1}$ \\ Anita Lima Figueiredo² \\ Francisca Lúcia da Silva ${ }^{3}$ \\ Luciana Mascena Silva ${ }^{4}$
}

\title{
Introdução
}

O presente artigo propõe uma discussão que tem como base superando os medos e as expectativas entre quem ensina e quem aprendem no período pandêmico. Para tanto é preciso analisar a escola dentro do seu formato atual, tendo em vista que a escola física era vista como espaço para aprender, onde só o educando e educador eram personagens. Entretanto, hoje a escola é um assunto que vem recebendo cada vez mais atenção. A hora presente é para o mundo presente, uma hora de transformação, onde todos estão vivenciando mo-

1 Graduada em Pedagogia - UECE; Especialista em gestão escolar - UFC; Especialista em metodologia do Ensino de Artes - UECE; Professora do município de Maracanaú/CE;

E-mail: alealdias2019@gmail.com

2 Graduada em Letras - UFC; Especialista em gestão escolar - UVA; Professora do município de Maracanaú/CE;

E-mail: anita.lima.figueiredo1@gmail.com

3 Graduada em Lucenciatura em Filosofia - UECE; Especialista em Gestão Escolar - UVA; Especialista em Metodologia do Ensino Fundamental e Médio -UVA; Especialista em Ciências do Ensino Superior - FAK; Professora do município de Maracanaú/CE; E-mail:wpenhalopes@gmail.com

4 Graduada em Biologia - UVA; Especialista em Auditoria ambiental - CENTEC; Mestra em Ciências Morfofuncionais - UFC;

E-mail: lumascena2@gmail.com 
mentos de incertezas, medo, perdas de entes queridos, amigos, conhecidos e desconhecidos, insegurança, angústia, estresse e até mesmo recolhimento, colocando o planeta em uma quarentena perversa atualmente e nos levando ao sofrimento com suas consequências.

Podemos dizer que estamos passando por um processo de "metamorfose humana", melhor dizendo uma transmutação física, moral e emocional, evidenciando a cada experiência a importância e o cuidado com nossa saúde mental e a do outro.

Assim partimos para um novo olhar e foco na ação educativa e inteligência emocional tanto de quem ensina como de quem aprende. Compreender todo esse processo emocional e de complexidade ao lidar com tais adversidades pressupõe compreender a relação entre educador e educando e as consequências que chegaram até as nossas escolas, nos desafiando frente a esse novo mundo, esse novo olhar, novas expectativas e desafios.

Partindo desse pressuposto surgem vários questionamentos: como se adequar a essa nova escola? Quem são os responsáveis pelo seu caminhar? É só o educando? É só o educador? Quem mais? Como será a qualidade do ensino? Como fica a participação dos educandos? Dos pais? E como planejar, preparar e executar as atividades escolares de forma on-line? E como preparar os envolvidos em educação para atender a essa demanda de trabalho o melhor possível, objetivando atender a todos?

Todavia, essa experiência relativamente nova na educação brasileira, nos trouxe a superação dos nossos medos, conflitos internos, nos fez perceber que para doar-se aos outros e aprender a fazer o que antes não nos 
era natural, requer novos pensamentos e consequentemente, novas ações pedagógicas dentro de um momento histórico que a educação está vivendo, onde se concebe novas práticas educacionais e o planejamento das aulas, atividades práticas e exitosas que mexessem com o interesse do educando e o colocasse como protagonista do seu fazer, em simultâneo, engajá-lo a participar ativamente das aulas todo e tornando essas atividades bem como as aulas on-line mais acessível e atraente agora.

Portanto, o grande desafio enfrentado tanto pelos educadores como pelos educandos é inovar o processo educacional com o uso de novas tecnologias e o aprender com o mínimo e/ou o quase nada de tecnologias em casa.

Partindo desse pressuposto este artigo é um convite para um novo olhar a partir das contribuições sobre como podemos desenvolver a inteligência emocional, segundo Goleman (2011), para superar os medos e expectativas de forma segura e com domínio emocional, preservando assim a saúde mental de nossos educadores e de nossos educandos durante o período pandêmico, refletir sobre o trabalho e a saúde mental do professor na atualidade a partir do uso de uma inteligência emocional voltada para a docência, para os desafios próprios do profissional em educação em acompanhamento aos educandos e familiares nas aulas remotas.

Para a elaboração deste, contamos com depoimentos e relatos de educadores sobre suas práticas exitosas nas atividades online, depoimentos de familiares, pesquisas bibliográficas e observações desenvolvidas em nossas instituições escolares por ter tem um papel importante na organização da sociedade, mas também se modifica em função desta. 
O impacto da pandemia sobre a vida das famílias com crianças, adolescentes e jovens em idade escolar é um fenômeno que ainda está por ser estudado em profundidade, o que deve acontecer ao longo dos próximos anos. Porém, enquanto isso não acontece, nós enquanto profissionais da educação, mesmo com um mínimo de informação tecnológica, mas com empatia e consciência social, sabemos ser possível partir de uma experiência pessoal e extrapolar para outros âmbitos no sentido de entender para aonde vai ou para onde deveria ir a nossa educação. E esta foi para a tela dos computadores, para aplicativos dos celulares, sites e plataformas digitais e até mesmo para a casa dos nossos alunos.

Para a efetivação de todo esse processo, foi preciso a participação de todos os educadores com seu núcleo gestor para organizar como se daria esse novo caminhar, esse novo processo educacional que não podia parar em meio a pandemia. E o primeiro ponto de partida foi a importância de conhecer os estudantes: como a escola está trabalhando para atendê-los? Quais os dados relativos ao desempenho escolar? Quais as principais dificuldades na aprendizagem?

Partindo da realidade de nossa clientela, sabendo das dificuldades em que se encontram as famílias dos mesmos, principalmente na ausência de recursos financeiros para a aquisição do material necessário à participação dos educandos nas atividades remotas, cabe a nós enquanto instituição, viabilizar práticas educativas e metodológicas que despertem o interesse, o acesso e a participação dos educandos, embora saibamos que muitos teriam dificuldades em adaptar-se ao ensino remoto, e para isso teríamos que apresentar uma segunda opção, visando garantir o acesso e a per- 
manência de todos, embora distante. Diante de qualquer escolha de ações a serem desenvolvidas, decorrerá dela: os conteúdos a serem desenvolvidos na sala virtual, a metodologia a ser empregada pelos docentes, a avaliação da aprendizagem escolhida, o processo de participação dos educandos nas diversas atividades escolares e a participação dos pais como incentivador deste processo.

Outro ponto importante e precisa ser ressaltado é o cuidado que a instituição ter com os educandos sem acesso a nenhum meio tecnológico digital sendo oferecido a opção de continuar suas atividades escolares com o uso contínuo dos livros didáticos que tem o (a) coordenador(a) pedagógico(a) o papel fundamental de fazer essa interação junto ao educando e repassando seu progresso escolar para os educadores, pelo qual os educandos recebem as orientações dos capítulos a ser estudado e as atividades que devem fazer para garantir seu direito à educação, seu acesso ao conhecimento e sua permanência na escola.

Porém, quando nos detemos em analisar o perfil de nossos educandos, chegamos a nos surpreender com tantas características comuns a quase todos, mesmo cada um sendo único, singular, mas fazendo parte de uma mesma realidade socioeconômica e cultural. A semelhança acontece desde a organização familiar, passando pelo nível socioeconômico, preferências, costumes e hábitos, tipos de diversão e até as perspectivas de futuro, incluindo os seus sonhos com a vida futura.

Do outro lado, os educadores, buscando alternativas para investir no crescimento intelectual e nas aprendizagens de seus educandos nesse novo formato de se fazer escola. O improviso de uma sala de aula 
virtual que os mantém distantes: educadores e educandos, o olhar, o cuidado que precisam ter e da ajuda diferenciada que necessitam oferecer a cada um mesmo que distante, de modo que eles possam fazer sozinhos aquilo que antes só faziam com o auxílio do educador, é um grande desafio. Toda essa responsabilidade trouxe insegurança e angústia mútua, não somente dos educadores e educandos, mas das famílias e demais pessoas envolvidas no processo educacional na totalidade.

Mudar a ideia de que os educandos não vão à escola presencialmente, que os espaços de interação, diálogos e aprendizagens entravam em um novo ritmo, e para muitos, desconhecido, carga horária excessiva de trabalho por parte dos envolvidos no processo ensino e aprendizagem, falta de apoio de órgãos superiores, e a desvalorização dos profissionais em educação, mexeu por demais com os sentimentos e emoções desses profissionais, lhes trazendo momento de aflição e sofrimento perante o novo. É sabido que os educadores não trabalham apenas na sala de aula e sem dúvidas, a mudança brusca de rotina e as dificuldades impostas pelo ensino remoto pioram ainda mais a saúde mental dos educadores, principalmente quando há falta de apoio emocional e treinamento por parte das demais instituições que deveriam mais do que nunca agregar neste momento.

Todavia, a natureza humana requer, entre as várias habilidades e competências necessárias a construção desse novo formato de escola, um conjunto de aptidões que incluem autocontrole, zelo, persistência, capacidade de automotivação. A esse grupo de aptidões chamamos "Inteligência Emocional", tão necessária nesses tempos complexos e confusos em toda e qual- 
quer área do conhecimento humano, seja ao nível pessoal ou profissional.

Inquestionáveis são os desafios que tem a educação frente a este mundo em constante renovação. Assim, considerar esse momento como mais um desafio, é também compreender que o sentimento de medo, não pode ser maior que nossa força, reconhecer em si mesmo, um poder capaz de mudar as circunstâncias. É o que chamamos superação e esta nos traz a compensação emocional das nossas forças de forma positiva.

Assim, considerando o educando e suas aprendizagens como nosso foco é a razão de ser do processo educacional, podemos enfatizar a importância de determinadas habilidades a serem desenvolvidas na escola no modelo de educação remota, utilizando seus saberes, vivências culturais e apropriar-se desses conhecimentos e experiências para adaptar às suas aulas ao mundo online, os medos perderam lugar para a superação e a vontade de fazer, se constituiu como manifestação das forças mentais para a realização dos nossos objetivos e do coletivo.

Não existem respostas prontas, mas pode- se inspirar em muitos caminhos. $\mathrm{O}$ mais inteligente e prudente mesmo é mobilizar os recursos próprios da inteligência emocional e enfrentar a situação com a firme disposição de não se deixar abater de forma alguma. O que também é um desafio tanto para os educadores como para os educandos. Mas, obstáculos são para vencer, e como educadores não desistem nunca, juntos buscamos apoio para superar mais esta adversidade. Assim, a relação escola-educador-educando e famílias começam a ser reconhecidos como instrumento principal das aprendizagens emocionais e escolares. 
Os educadores por sua vez, devem considerar aspectos importantes dos seus educandos, tais como: a participação das aulas e demonstrando interesse por elas, flexibilidade do tempo e horário para participar das aulas, buscar usar atividades possíveis de serem realizadas em aulas remotas, bem como usar jogos e personagens que os educandos gostam e conhecem (educação Infantil e Fundamental I), adaptando para a internet atividades lúdicas, apresentações, projetos e culminâncias que fazia presencialmente, estimular, construir espaços de diálogos e interação, buscar alternativas para manter os educandos engajados, enfim aplicar metodologias ativas de aprendizagem significativas, tornando-os como protagonistas desse processo educacional.

Podemos enfatizar que as atividades exitosas foi uma ferramenta a mais de participação e de construção da autonomia das crianças. É preciso ressaltar, que quando falamos das atividades elaboradas para os estudantes, trabalhamos também com suas dificuldades de aprendizagem, e com suas emoções, que foram bastante despertadas nesse período de pandemia. A falta de interação com a escola e com os amigos, as limitações financeiras e mesmo alimentar, a falta de acompanhamento dos pais devido o tempo fora de casa por conta do trabalho, ou mesmo por negligência à vida escolar dos filhos, muitos deles perderam o vínculo com a escola e isso os entristeceu, levando alguns terem problemas de saúde devidos ao estágio de emoções que imbuídos de tantos outros sentimentos, lhe afetam para o bem ou para o mal do corpo e/ou mente, causando-lhes ansiedade que é uma emoção como qualquer outra, mas o excesso dela pode ser muito prejudicial à saúde emocional. Porém, muitas vezes a ansiedade é apenas um 
sintoma de algo mais profundo que você não faz ideia; e essa ansiedade acometeu também familiares dos educandos e muitos profissionais da educação.

E mais uma vez, a escola foi um condutor de energias para agregar à toda nossa comunidade escolar, a lei da solidariedade e da escuta, prestando-lhes ajuda, repondo o equilíbrio das situações apresentadas.

'A humanidade é um grande ser coletivo, cada indivíduo dela componente deve interessar-se no aperfeiçoamento dos seus semelhantes, certo que todo atentado à dignidade pessoal fere a coletividade e toda boa ação individual se reflete beneficamente sobre a massa"(Psicologia Aplicada ao Comportamento. Pag.138)

Apesar de estarmos mais distantes dos nossos educandos fisicamente, a interação deles e suas famílias têm sido maiores. Sentimos angústia pela falta de convivência com eles durante a pandemia, pois sentimos falta dos sorrisos, abraços, brincadeiras e de tantos momentos que cultivamos dentro desse espaço de aprendizagens múltiplas. É também para a escola o ambiente de formação intelectual de cidadãos que podem e devem fazer grandes transformações sociais. E, nesse momento de mudança no cenário da educação no país, onde o espaço físico escolar passou a acontecer no ambiente familiar e, para tanto, precisou as aulas remotas se tornar fundamental enquanto escola real foi também necessário fortalecer a participação dos pais e/ou responsáveis pelos educandos, se constituírem como participantes ativos do processo ensino aprendizagens de seus filhos.

Entendemos que muitos não foram e nem estão preparados para esse auxílio pedagógico, e isso con- 
sequentemente, lhes trouxe aflição e preocupação. Foi preciso um diálogo esclarecedor entre escolas e famílias para estes compreenderem o momento presente, bem como a importância de se manter o vínculo do educando com sua escola e seus professores. Assim, a colaboração dos pais torna-se imprescindível para o engajamento dos educandos às atividades exitosas propostas, bem como, fundamental para garantia do sucesso e alcance dos nossos objetivos educacionais.

Então, partindo do pressuposto que, cabe à escola viabilizar práticas educativas e metodológicas que despertem o interesse dos educandos, de modo a recuperar a sua função social que é sua aprendizagem, destacamos aqui, uma parceria de verdade, com uma grande maioria dos pais, pois quando precisamos de qualquer apoio, eles estão prontos e disponíveis a colaborar com os educadores, e isso fortalece a relação escola-família.

Notamos também as dinâmicas que os educandos vivenciam nas aulas que lhes são transmitidas remotamente. $O$ sentimento de angústia e incertezas muito presentes devido a essa falta de convivência com eles, mas enfatizamos que estamos cotidianamente presentes através da tela do celular orientando e participando da vida de todos. E aqui cabe muito bem a frase de Goleman: "Inteligência emocional contribui com um número maior de qualidades que nos tornam mais plenamente humanos". E assim os momentos felizes e engraçados, de troca e de aprendizado, de se renovar para transformar o que se tinha em algo novo, eficiente e eficaz capaz de nos trazer a legitimidade do nosso fazer pedagógico através de práticas exitosas, onde se evidencia que mesmo com todas as dificuldades apresen- 
tadas, educadores e educandos são motivados a nova sistemática de educação escolar, que está contribuindo para o bem-estar de todos.

\section{Depoimentos de Professores:}

"As aulas remotas são um grande desafio. A pergunta é: como trabalhar com as crianças nesse período de pandemia? Como alcançar todas as crianças com esse novo método de ensino? Diante de tantas peculiaridades, me angustiou por meses. Mas mesmo com todo o susto e medo desse momento, decidi usar o WhatsApp como ferramenta de ensino visto que a maioria dos pais tinha acesso ao aplicativo e a internet.

Usamos todos os recursos do APP, desde uma simples mensagem de texto, a videochamadas em pequenos grupos. Envio de sequências de vídeos com experiências e orientações bem detalhadas para as crianças no intuito que elas consigam reproduzir em casa com a ajuda de seus pais. Para as crianças que não possuem acesso à internet, a escola se propôs a reproduzir atividades xerocopiadas previamente preparadas pelos professores que prontas, avisamos aos pais, e estes vão buscar na escola. Mesmo superando nossos medos no dia-a-dia, ainda estamos longe do que sonhamos para a qualidade do trabalho escolar e das aprendizagens com os resultados que esperamos com este novo modelo de escola durante a pandemia no ano de 2020, mas estamos nos empenhando para garantir a educação de nossas crianças com todo amor e garra havendo em nós educadores" (Professora Manuela Santos - PRÈ I E II) 


\section{Depoimentos de Pais de alunos:}

"Na minha opinião, é muito difícil as crianças estarem longe da escola, mas temos que manter o distanciamento social por conta da pandemia. É muito importante que as crianças tenham o acompanhamento das professoras, que tenham atividades para fazerem, pois, as crianças precisam de uma rotina, precisam ter hora para estudar e hora para brincar. Sou mãe, dona de casa e trabalho fora, mas sempre tiro um tempo para interagir com meu filho e fazer as atividades com ele. Parabenizo as professoras, pessoas maravilhosas que sempre que precisamos, tiram nossas dúvidas e são muito atenciosas.

É muito importante as aulas à distância para que as crianças tenham responsabilidade. Se Deus permitir, tudo voltará ao normal e levaremos tudo isso para as nossas vidas como uma lição para sermos pessoas melhores”. (Bárbara- mãe do aluno Marlon Breno -PRÉ I-B-Manhã)

\section{Atividades Exitosas:}

ATIVIDADE 1

Criação do Jornal Informativo

Objetivo: manter um canal de informação e relação entre escola e família, bem como utilizar o jornal como portefólio do trabalho da escola durante o período de pandemia.

\section{Atividade 2}

\section{Feira de Ciências Virtual}

Objetivo: instigar a curiosidade científica dos alunos sobre a extinção dos dinossauros e o início do universo. A professora Eliziete Aquino realizou aulas 
virtuais, durante a semana, em que os estudantes pesquisaram, produziram réplicas de dinossauros e gravaram vídeos explicando sobre o ciclo de vida dos animais e sua alimentação.

A professora Eliziete Aquino conta como surgiu a ideia de trabalhar esse tema. "Realizamos um trabalho sobre os animais em extinção, Pássaro Dodô que está no livro de Ciências. Então, fiz a proposta para realizarmos uma Feira de Ciências Virtual, onde cada aluno pesquisou o dinossauro da sua preferência. Foi onde envolvi a matemática e ciências. Os alunos pesquisaram nome, tamanho, peso, alimentação, tempo em que viveu e um trabalho artístico. Eles gravaram vídeos com a ajuda das mães que também estavam empolgadas com o trabalho proposto".

Charleny de Sousa, técnica formadora do 3. ano da Secretaria de Educação, participou auxiliando com vídeos sobre como visualizar animais em $3 \mathrm{D}$, pesquisas e com edição de vídeos. As apresentações podem ser assistidas pelo canal do YouTube disponível no link: bit. ly/2CbqEmO. (Bruna Marques)

\section{Considerações finais}

Relembrando a célebre frase de Paulo Freire "Ensinar exige a convicção de que mudança é possível”, à docência, em si, reúne diversos fatores que interferem no emocional dos profissionais da área, fatores estes que lhes geram angústias, estresses e um conjunto de outros sentimentos que lhes causam mal-estar.

Os profissionais em educação, em especial os educadores, precisam conhecer e usar sua inteligência emocional de modo a construir momentos mais positi- 
vos, dentro e fora do ambiente de trabalho, e, ainda, desconstruir os momentos de sofrimento que os desafios da profissão lhes impõem, como nesse formato de novo de se fazer escola, ou seja, o ensino remoto, sendo atualmente, uma experiência relativamente nova em nosso país que chegou ao ensino brasileiro, criando relações sociais de trabalho e nos dando condições para viabilizá-la dentro das nossas possibilidades profissionais, de fazermos aquilo que entendemos ser melhor para a escola e para a aprendizagem dos nossos educandos desde da educação infantil ao ensino fundamental II.

Levar o processo educacional para o outro lado das telas, de forma atraente, compreensível à linguagem de nossos educandos, seus familiares, e através dele superar o medo vivenciado por todos, à escola virtual com o passar dos dias, passa a ser uma preocupação maior com os estudantes distanciados da escola física, se angustiam e sofrem nesse momento de pandemia, fazendo-os muitas vezes, se desinteressar pelo estudo por conta das dificuldades encontradas e acabam se evadindo. E cabe por parte de todos um olhar minucioso e ações bem definidas e acompanhadas para que isso não se torne do desafio a ser superado ao fracasso escolar, assim a busca ativa e diária desses educandos é fundamental neste processo.

Deve a escola coletivamente repense suas mudanças que devem partir, da nossa atuação enquanto profissionais perante esses desafios, mantendo nosso autocontrole e nossa motivação para encarar essa transformação de forma que estas nos restabeleça o equilíbrio emocional de forma que seja favorável a todos, para que assim, educadores, educandos, famílias e a escola como um todo, possam superar os medos que este 
novo desafio trouxe ao seu cotidiano, criando expectativas, tendo consciência de seus sentimentos e emoções para que juntos, possamos enfrentar os desafios da profissão sobretudo no panorama atual, de uma nova escola em construção, que nos tornou protagonistas do nosso fazer pedagógico, enquanto essa nova rotina de trabalho influencia o emocional de todos os envolvidos.

É preciso ainda que os educadores e os demais profissionais da educação em geral, ao pensar nas aprendizagens escolares no ensino remoto durante esse período de pandemia, sejam sensíveis às condições que estes educandos se encontram junto aos seus familiares, partindo desse pressuposto, desenvolver atividades exitosas, bem elaboradas com um formato adaptável à sua rotina em casa, espaço e acompanhamento familiar, permitindo também que possam definir os horários de preferência para o estudo das atividade e uso dos materiais, contando que a dinâmica das atividades lhes tragam inspirações para o seu dia a dia junto à escola. E por fim, acreditar que tudo pode dar certo é a forma de preparar o caminho para que algo bom aconteça. Isso nós chamamos esperança!

\section{Referências}

FERREIRA, Naura Syria Carapeto(org.) Gestão Democrática da Educação: Atuais Tendências, Novos desafios. São Paulo: Cortez.

CURY, Augusto. Seja líder de si mesmo. Ed. Especial. Rio de Janeiro. Sextante 2009.

GOLEMAN, Daniel, ph.D. Inteligência emocional. A teoria revolucionária que define o que é ser inteligente. Rio de Janeiro: Objetiva, 2007. 
GOLEMAN, Daniel. Inteligência Emocional. Rio de janeiro: Objetiva, 2011.

LIBÂNEO, José Carlos. Didática. São Paulo: Cortez, 2006.RODRIGUES, Miriam. Educação emocional positiva-ed. rev. amp. Novo Hamburgo: Sinopsys, 2015.

SOUSA, A. T. C; FREITAS, M. C. M. A. A interferência da inteligência emocional na práxis do professor. UniEVANGÉLICA,2016 
0 GESTOR ESCOLAR COMO CUIDADOR: DESAFIOS

VIVENCIADOS NA COMUNIDADE ESCOLAR NO IMPACTO

DA COVID -19

Emília Régia Venâncio Gomes ${ }^{1}$

Fransilvia Barroso Machado²

Nivea Maria Costa Vieira ${ }^{3}$

Rita Cristiane de Oliveira Gomes ${ }^{4}$

Luciana Mascena Silva ${ }^{5}$

\section{Introdução}

A sanidade mental é parte integrante da saúde, na verdade, não há saúde do corpo, sem saúde mental. Não se pode entender ou transformar a situação de saúde

1 Graduada em Licenciatura Ciências da Religião Pedagogia pelo ICRE e UNIFRAN; Especialista em Gestão Escolar e Docência do Ensino Superior pela UFC e FAK; Ministra aula na Graduação nos cursos de Pedagogia pelo IDJ/UVA e FACESMA; Professora efetiva da Educação Básica do Município de Maracanaú

2 Graduada em Pedagogia - UVA; Especialista em Gestão Escolar e Coordenação Pedagógico - FACESMA Especialista em Docência do Ensino Superior - FACESMA; Psicopedagogia Clínica e Hospitalar - FACESMA; Palestrante em temas da psicologia comportamental; Professora do município de Maracanaú/CE; E-mail: simplesmentesilvia1@gmail.com

3 Graduada em Pedagogia - UVA; Especialista em Administração Escolar - UVA; Especialista em Docência do Ensino Superior - FACESMA; Professora do Município de Maracanaú/CE; E-mail: niveamaria.costa@educacao.fortaleza.ce.gov.br

4 Especialista em Docência do Ensino Superior - Facesma; Gestão Escolar e Coordenação Pedagógica - Falc; Psicopedagogia Clínica, institucional e hospitalar - CETREDE; Gestão e Políticas Públicas - Fak. Graduada em Licenciatura Pedagogia - UVA; Professora da rede municipal de Maracanau há 33 anos e de Fortaleza há 20 anos; Atualmente Diretora Acadêmica da Faculdade Cesma de Maracanaú- FACESMA; E-mail: cristiane@facesma.com.br

5 Graduada em Biologia - UVA; Especialista em Auditoria ambiental - CENTEC; Mestra em Ciências Morfofuncionais - UFC; E-mail: lumascena2@gmail.com 
de um indivíduo ou de uma coletividade sem levar em conta que ela é produzida nas relações com o meio físico, social e cultural.

Segundo a Fundação Nacional de Saúde (1994)

A promoção de saúde ocorre\{...\} por meio da elaboração, da adoção de estilos de vida saudáveis, do desenvolvimento de aptidões e capacidades individuais, da produção de um ambiente saudável, da eficácia da sociedade na garantia de implantação de políticas publicas voltadas para a qualidade da vida e dos serviços de saúde. (Ministério da Saúde, mec.gov.br)

Os docentes da rede pública e privada se declaram ansiosos e nada realizados com o trabalho no momento atual. $O$ que acende um sinal de alerta. Pesquisa realizada pela Nova Escola (2021): cerca de 5 mil professores em todo o Brasil revelou que $60 \%$ sofrem com ansiedade, estresse e dores de cabeça e $66 \%$ já sentiram fraqueza, incapacidade ou medo de ir trabalhar. Para $87 \%$, os problemas de saúde são ocasionados ou intensificados pela profissão. Onde $70 \%$ deles se dizem ansiosos e só $3 \%$, realizados. E a maioria $75,2 \%$ relata que não receberam até agora nenhum apoio emocional da escola em que trabalha.

A permanência do quadro de incerteza imposto pelo momento pandêmico da COVID-19, tem desafiado diferentes setores que vão além da contenção da doença no país.

No cenário educacional, um dos grandes desafios, se diz respeito aos cuidados com os aspectos emocionais, daqueles que estão na linha de frente das unidades escolares. Diante dessa realidade, abre-se um leque de discurso a respeito da saúde emocional do profissional da educação, com foco na gestão. 
De que forma o Gestor Escolar, administra o autocuidado e enfrenta os desafios imposto com a pandemia COVID-19 na sua comunidade escolar?

Contudo, será apresentada uma pesquisa qualitativa (GODOY, 1995), onde se pretende analisar, refletir e compreender os comportamentos dos diversos segmentos que envolvem a comunidade escolar.

A pesquisa terá como fonte, as Instituições escolares da rede pública de Maracanaú. Através de dados gerados por amostragem, aplicações de questionários e estudo de casos, onde serão consideradas, as particularidades e experiências de cada instituição. Abordando a atuação do Gestor Cuidador, acerca da sua administração nos diversos aspectos.

\section{Os desafios do Ensino Remoto}

Hoje não se concebe mais, gerenciar uma instituição sem utilizar os recursos tecnológicos que estão sendo disponibilizados. No "novo normal" que se apresenta a tecnologia como ferramenta de ensino pode e está auxiliando no processo educativo, burocrático e com essa facilidade se enquadra no dia-a-dia de todos os envolvidos professores; alunos, pais e gestores.

Velloso (2014, p.11) conceitua as Novas Tecnologias de Informação e Comunicação (NTICs) como artifícios utilizando para agilizar, horizontalizar e facilitar a captação, a transmissão e a distribuição de informações em rede surgidas no contexto da Terceira Revolução Industrial, desenvolvida gradativamente desde a metade da década de 1970, com o auge nos anos de 1990.

As tecnologias na educação, oferecem grandes benefícios, se considerarmos a flexibilidade, e otimização 
do espaço de tempo, tornando possível o acesso de professores, alunos, coordenadores, através do compartilhamento de materiais na ferramenta Google, por exemplo.

$O$ gestor neste contexto passa a ser um mediador das articulações em grupos e salas de aula virtuais, promovendo uma interação institucional entre alunos, professores e pais, diante das demandas escolares.

De modo geral. as novas tecnologias estão associadas a interatividade e a quebra do modelo comunicacional-um-todos, em que a informação é transmitida de modo unidirecional, adotando o modelo todos, em que aqueles que integram redes de conexão atuam no envio e recebimento das informações ( VELLOSO, 2014, P.12).

A problemática instaurada pela COVID 19 direciona a comunidade escolar a utilizar ferramentas digitais na redução do distanciamento entre escola e família. Partindo desse princípio compreende-se que o Gestor deve estar preparado para ministrar esses desafios. Buscar junto ao professor, receber formações continuadas para o manuseio das tecnologias digitais de forma complementar à sua práxis, levando em consideração que hoje, as tecnologias, tornam-se ferramentas indispensáveis na atuação de suas funções.
[...] compreender, utilizar e criar tecnologias digi- tais de informação e comunicação de forma crí- tica, significativa, reflexiva e ética nas diversas práticas sociais (incluindo as escolares) para se comunicar, acessar e disseminar informações, produzir conhecimentos, resolver problemas e exercer protagonismo e autoria na vida pessoal e coletiva (BRASIL,2017, p.9).

Nessa perspectiva, todos que estão à frente da instituição escolar, precisam assumir o papel de aprender 
e se reinventar, enfrentando desafios funcionais que perpassam por toda comunidade escolar.

\section{Os Impactos Pandêmicos na Comunidade Escolar}

A gestão escolar procura assegurar aquilo que é próprio de sua finalidade garantido na $\operatorname{LDB}(\mathrm{p} .26)$ no que diz respeito promover o ensino-aprendizagem corroborando a educação como um direito de todos.

Frente ao cenário da pandemia, a figura do gestor escolar como liderança do processo ensino-aprendizagem é de suma importância para gerenciar ações e garantir um trabalho de excelência no cotidiano escolar.

Segundo Luck, o conceito de liderança por sua vez, destaca: liderança como sendo o processo de influência, realizado no âmbito da gestão de pessoas e de processos sociais, no sentido de mobilização de seu talento e esforços, orientados por uma visão clara e abrangente da organização em que se situa e de objetivos que deva realizar, com a perspectiva da melhoria contínua da própria organização, de seus processos e das pessoas envolvidas. (LUCK 2014. p.35)

Na dimensão gestão, liderar viabiliza um diálogo entre todos os segmentos e comunidade escolar em busca de fomentar a função social da escola. Procurando conduzir da melhor forma o clima escolar do grupo docente e discente, garantindo uma saúde mental estável refletindo nas relações interpessoais.

No atual contexto pandêmico os gestores escolares de Maracanaú, enfrentam grandes desafios diante da realidade de desigualdade social, e exclusão digital, comprometendo significativamente a aprendizagem escolar. 
No entanto, houve uma necessidade de adaptar-se a um "novo normal" improvisado nas instituições escolares e dos professores, assim foi inserido o ensino remoto nos grupos de ferramentas tecnológicas.

Leal (2020) destaca que, diante da nova realidade imposta pela situação de pandemia, as limitações que existem no processo de ensino e aprendizagem tornaram-se mais evidentes, isso porque o momento acentuou ainda mais como a desigualdade social tem implicações negativas na aprendizagem de alunos em situações de vulnerabilidade econômica.

Considera-se que cenário atual, mostra dentre outros desafios, um dos mais pertinentes, a divisão no uso de um aparelho celular entre pais e filhos, inviabilizando o tempo de orientação remota por parte do professor e a falta de conhecimento tecnológico por parte dos pais nas orientações das atividades, comprometendo assim a aprendizagem escolar.

Uma realidade onde a minoria das famílias assistidas pela escola, não tem acesso ou aquisição de equipamentos tecnológicos. A busca pela equidade torna-se um grande desafio para o gestor diante de sua comunidade escolar.

Professores e gestores escolares têm a figura desafiadora nesse novo modelo de ensino. Utilizar com propriedade as ferramentas tecnológicas e motivar os alunos a interagir e compreender as informações repassadas, bem como, entender que essa nova forma de ensinar fará parte do seu cotidiano daqui para frente.

\section{Os aspectos Emocionais na Gestão Escolar}

Estudos comprovam que cresce cada vez mais o índice da população mundial que sofre de transtornos 
psicológicos. Não se pode afirmar que todos eles sejam motivados pela vida profissional, considerando o cenário evidenciado com a (COVID-19).

Compreendendo que hoje, o profissional da educação, precisa não só gerir suas competências profissionais, mas também suas competências emocionais diante dos desafios de cuidar dele e do outro.

Cuidar é mais que um ato; é uma atitude. Portanto abrange mais que um momento de atenção, zelo e desvelo. Representa uma atitude de ocupação, preocupação, responsabilidade e envolvimento afetivo com o outro. (BOFF, 2001, p.33)

O conceito de cuidado é amplo e aborda a integralidade do sujeito. Cuidar é uma atitude de preocupação e envolvimento com o ser humano. Envolve afeto e respeito com o outro ser.

Diante dessa conduta, surge a interrogação: quem cuida de quem cuida?

No autocuidado a preocupação e atenção foca em cuidar de si mesmo. Então, para cuidar, de alguém ou de si, é preciso ter estima e afeto, eu preciso desejar o seu bem-estar, na forma integral.

Vale ressaltar que não precisamos excluir o cuidado conosco para exercer o cuidado com o outro. Podemos cuidar de nós enquanto cuidados do outro. Autocuidado não é auto indulgência, mas é autopreservação.

Cuidar do interior, fortalecendo a autoestima, reflete no exterior. $\mathrm{O}$ autoconhecimento, autoconfiança, trabalhar as vulnerabilidades, e analisar, são caminhos para o auto controle. Percebe-se que o momento de pandemia tem nos exigido respostas rápidas; mas como tê-las para algo tão novo? 
Vale ressaltar que, mesmo antes da pandemia evidenciada com a COVID-19, a sociedade já caminhava para um processo de individualização, com a perda da rede de apoio e da convivência em comunidade. $\mathrm{O}$ fato é que as doenças mentais relacionadas ao ambiente de trabalho vêm ganhando mais espaço e trazendo mais impactos, comprometendo os aspectos emocionais das pessoas, e o clima organizacional nas instituições.

A melhor forma de prevenção é com estratégias que diminuam o estresse e a pressão. Adquirir hábitos de conduta saudáveis, evitando o desenvolvimento da doença, tratando sinais e sintomas logo no início.

Compreende-se que hoje, o profissional da educação, precisa não só gerir suas competências profissionais, mas as competências emocionais diante dos desafios de cuidar dele e do outro. Mas como gerir tudo isso?

Considera-se a importância desse Gestor ser assistido nas suas necessidades básicas, o contrário, irá influenciar, comprometendo e interferindo no atendimento do serviço por ele prestado.

\section{Metodologia}

O presente trabalho trata-se de uma pesquisa do parecido com exploratória numa pesquisa de campo, que segundo Gil (2002) é utilizada quando a pesquisa visa familiarizar-se ou conhecer o fenômeno, ou obter nova percepção do mesmo.

Objetivando identificar os desafios enfrentados pelos Gestores Escolares nas instituições do município de Maracanaú, durante a COVID-19. Elaborou-se um protocolo de pesquisa, em forma de questionário, por amostragem em catorze escolas que estiveram em 
funcionamento, na modalidade ensino remotos com as seguintes perguntas.

1. Quais foram os principais desafios enfrentados pela comunidade escolar no período pandêmico?

2. Em relação às aulas remotas, quais foram as maiores dificuldades?

3. Algum membro do núcleo gestor desenvolveu algum problema emocional?

\section{Análise dos dados apresentados}

As respostas do questionário aplicado, resultaram numa gama de informações. Ressaltamos que o questionário foi direcionado aos gestores de forma online. Segue a baixo os resultados compilados.

1. Quais Foram Os Principais Desafios Enfrentados Pela Comunidade Escolar No Período Pandêmico?

2.QUAIS FORAM OS PRINCIPAIS DESAFIOS ENFRENTADOS PELA COMUNIDADE ESCOLAR NO PERIODO PANDÊMICO?

14 respostas

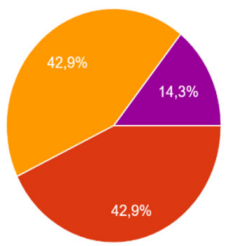

A) EVASÃo dOS ALUNOS

B) FALTA DE ACOMPANHAMENTO DOS PAIS

C) FALTA DA PARTICIPAÇÃO DOS ALUNOS NAS AULAS ON LINE

D) FALTA DE CONHECIMENTO TECNOLÓGICO

E) OUTROS MOTIVOS. QUAIS?

Gráfico 01- A falta de participação dos alunos em $42 \%$ nas aulas online mostra um percentual paritário a $42 \%$ na falta de acompanhamento por parte dos pais. Considerando a falta de conhecimento tecnológico e a desmotivação frente ao sistema remoto que se camuflam entre os $14,3 \%$. 
2. Em relação às aulas remotas, quais foram as maiores dificuldades?

6. EM RELAÇÃO AS AULAS REMOTAS, QUAIS FORAM AS MAIORES DIFICULDADES?

14 respostas

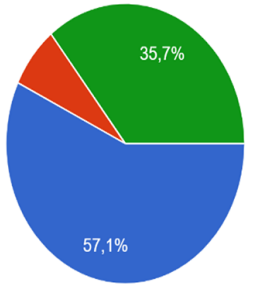

A) FALTA DE CONEXÃO COM A INTERNET POR PARTE DOS ALUNOS

B) FALTA DE DOMINIO TECNOLÓGICO POR PARTE DE PAIS E/OU ALUNOS

C) FALTA DE DOMINIO TECNOLÓGICO POR PARTE DE AL...

D) FALTA DE INCENTIVO

TECNOLÓGICO NAS ESCOLAS MU...

E) NÃO TIVEMOS DIFICULDADES

Gráfico 02 - Apresenta desafios pertinentes, em relação a falta de conexão às aulas, $55 \%$ dos alunos consideram-se desconectados pela internet, levando em consideração a adesão ou acesso à internet por parte das famílias. 35,7\% deles se dizem desmotivados ao modelo remoto. Ressaltando as dificuldades de $15 \%$ no conhecimento tecnológico por parte dos pais e alunos em seguir as orientações das atividades direcionadas pelos professores.

3. Algum membro do núcleo gestor desenvolveu algum problema emocional?

3. ALGUM MEMBRO DO NÚCLEO GESTOR DESENVOLVEU ALGUM PROBLEMA EMOCIONAL? 14 respostas

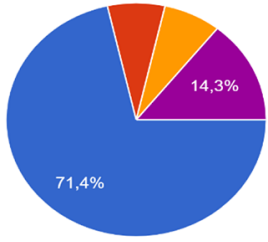

A) SIM. ANSIEDADE

B) SIM. DEPRESSÄO

C) SIM. SINDROME DO PÂNICO

D) SIM. SINDROME DE BOURNOUT

E) NĀO. NENHUM PROBLEMA EMOCIONAL

Opção 6

Gráfico 03 - Percebe-se que 75\% dos Gestores entrevistados desenvolveram um quadro de ansiedade frente ao trabalho às escolas no período pandêmico 
considerando as demais patologias nesse gráfico apresentadas. Nesse processo, faz se necessário que aquele que está a gerir os impactos diante da comunidade escolar, desenvolva habilidades de autocuidado. Preservando assim sua saúde emocional.

\section{Conclusão}

No presente estudo, foram apresentados, saberes à respeito da saúde mental do Gestor escolar e os desafios enfrentados nas instituições de ensino, diante do cenário pandêmico do coronavírus. Em suma compreende-se que o controle emocional da Gestão reflete positivamente na superação desses desafios.

$\mathrm{O}$ ato de cuidar da saúde emocional envolve a realização de intervenções durante a vigência da pandemia para minimizar implicações negativas e promover a o bem-estar de toda comunidade escolar. Bem como a preocupação com o retorno às instituições, no readaptar e lidar com as perdas e transformações posteriores.

A pesquisa apresenta o quão esta pandemia foi danosa para a educação brasileira, pois boa parte da população é muito carente e não dispõe dos recursos necessários para a qualidade de ensino a partir de suas residências. Causando desmotivação por parte dos alunos e tristeza para os pais na falta de interesse e baixo rendimento apresentado pelos filhos.

Pode-se concluir que, por mais triste e difícil que tenha sido esse período, os que estão à frente das instituições escolares do município de Maracanaú não desistiram na sua missão. Diante de todas as dificuldades, buscam ações ativas de resgate ao estudante.

$\mathrm{Na}$ perspectiva de minimizar os danos causados pela covid-19, a comunidade escolar, a Gestão Escolar 
incube-se do seu atual, porém mais pertinente, o de Gestor cuidador.

\section{Referências}

Boff L. Publicações. 2003. citado em 23 maio de 2003. Disponível em: URL: www.leonardoboff.com

Brasil, Secretaria de Educação Fundamental. Parâmetros curriculares nacionais:introdução aos parâmetros curriculares nacionais. Brasília: SEF, 1997

BRASIL. Ministério da Educação, Lei n.9.394, de 23 de dezembro de 1996. Fixa as diretrizes e bases da educação nacional. Brasília, 1996.

FERREIRA, Anna Rachel. Mudança de rotina: Como se manter próximo das famílias em tempos de pandemia. Revista Nova Escola São Paulo. Acesso em: https://nova escola.org. br / conteúdo / 1987 / mudança- de- rotinacomo -se- manter- próximo- das- famílias- em- temposde- pandemia. Acesso em 15 outubros 2020.

LEAL, Paulo Célio de Souza. A educação diante de um novo paradigma: ensino a distância (ead) veio para ficar!. Gestão \& Tecnologia Faculdade Delta, v. 1,n.30,p.41-43.jan./jun.2020

LUCK, Heloisa. Liderança em Gestão Escolar. Petrópolis: Série Cadernos de Gestão. Vozes, 2014.

QUALITATIVA E SUAS POSSIBILIDADES *Arllda Schmidt Godoy em junho/1994, avaliado em agosto/1994 e janeiro/1995, aprovado para publicação em janeiro/1995. Revista Nova Escola; disponível em:https:// novaescola.org.br/conteudo/17037/como-promover-a-saude-mental-do-docente. acessado em 04 de outubro 2021

VERGARA, Sylvia Contant. Gestão de Pessoas 2. ed. São Paulo: Atlas 2000 


\title{
REFLEXÃO DOCENTE E A IMPORTÂNCIA DA INTELIGÊNCIA EMOCIONAL NA EDUCAÇÃO DE JOVENS E ADULTOS DURANTE 0 ENSINO REMOTO
}

\author{
Francisca Rousane Sales de Oliveira Andrade \\ Isabel Cristina da Silva Martins² \\ Maria do Socorro de Melo Gonzaga ${ }^{3}$ \\ Nely Germano 4 \\ Luciana Mascena Silva ${ }^{5}$
}

\section{Introdução}

A Educação de Jovens e Adultos precisa ser bem estruturada, diante disso o docente precisa estar preparado para o ensino deste público, identificando a importância da inteligência emocional na educação principalmente durante o ensino remoto que é cheio

1 Psicopedagogia Clínica e institucional/KURIOS ,Gestão e Coordenação escolar/FACESMA, Atendimento Educacional Especializado com Ênfase em Libras/FACESMA.Graduada em Pedagogia/ Kurios Graduanda em Fisioterapia /UniFametro.. Professora efetiva da Educação Básica do Município de Maranguape/CE e Professora efetiva da Educação básica do Município de Palmácia /CE E-mail:rousanesales@gmail.com

2 Bacharelado em Administração de Empresas na Universidade Estadual do Ceará, Licenciatura em Matemática também na *UECE e Gestão Escolar na FADESNE. Sou Servidora Pública Concursada da Prefeitura Municipal de Maracanaú.

3 Graduada em Pedagogia - UVA; Especialista em Gestão da Educação Pública - UFJF; Coordenadora Administrativa Financeira do município de Maracanaú/CE; Email: socorromelo123@gmail.com

4 Graduada em Administração - UNP; Especialista em Gestão Pública - FAK; Especialista em Docência do Ensino Superior - FAK; Profissional da Área Financeira com mais de 30 anos mercado; Coordenadora Administrativa Financeira - Facesma;

E-mail : nelygermano@gmail.com

5 Graduada em Biologia - UVA; Especialista em Auditoria ambiental - CENTEC; Mestra em Ciências Morfofuncionais - UFC;

E-mail: lumascena2@gmail.com 
de incertezas e medo para os estudantes que muitas vezes não dominam as tecnologias ou não possuem os equipamentos necessários para acompanhar as aulas remotas (PALÚ; SCHUTZ; MAYER, 2020).

A inteligência emocional é a capacidade do ser humano de lidar com as emoções, chegando a agir com inteligência e equilíbrio o que favorece ao aprendizado efetivo, uma vez que é vital conhecer e controlar as emoções, assim como agir na motivação dos alunos, para que mesmo diante das dificuldades haja continuidade nos estudos (CASASSUS, 2009).

Diante do contexto apresentado, buscamos compreender como a inteligência emocional contribui para educação de jovens e adultos durante o ensino remoto.

São muitas as dificuldades diante desta nova modalidade de ensino, docentes e discentes possuem dificuldades, pois, muitos não possuem conhecimento sobre as tecnologias digitais, ainda assim é preciso superar os desafios, a fim de continuar os estudos, onde os professores têm o papel de possibilitar o aprendizado e motivar os alunos (COLEMARX, 2020).

O objetivo geral da pesquisa é identificar a importância da inteligência emocional na educação do EJA durante o ensino remoto. Os objetivos específicos são relatar sobre os princípios do EJA, discorrer sobre a inteligência emocional para jovens e adultos, como ocorre o ensino remoto, e os desafios enfrentados por alunos e professores no ensino remoto, e como utilizar a inteligência emocional para melhores resultados na aprendizagem.

A importância da pesquisa se justifica pela necessidade de debater sobre os desafios encontrados no ensino remoto, e como a educação emocional contribui 
no processo de ensino, pois, este estudo irá contribuir para que docentes e discentes tenham maior conhecimento do tema.

\section{A Educação de Jovens e Adultos}

A educação Brasileira era direcionada a crianças, sendo que os Jesuítas alfabetizaram os indígenas adultos, mas com a saída deles do Brasil não foi continuado à educação para adultos e apenas as crianças de elevada classe social tinha acesso à educação (VENTURA, 2011). Assim, no século XX foi criada a Liga Brasileira contra o Analfabetismo com o objetivo acabar com a falta de instrução no Brasil uma vez que se relacionou a falta o subdesenvolvimento do país a falta de educação.

Inicialmente a alfabetização de adultos para os colonizadores, tinha como objetivo instrumentalizar a população, ensinando-a a ler e a escrever. Essa concepção foi adotada para que os colonos pudessem ler o catecismo e seguir as ordens e instruções da corte, os índios pudessem ser catequizados e, mais tarde, para que os trabalhadores conseguissem cumprir as tarefas exigidas pelo Estado. (LOPES; SOUZA, 2010, p.3)

No decorrer das décadas foram surgindo diversas Leis e movimentos para promover a educação, a Lei Orgânica do Ensino Primário em 1946 que previa o supletivo, depois a criação do Serviço de Educação de Adultos, com o objetivo de coordenar o ensino e planos anuais do ensino supletivo, este movimento foi chamado Primeira Campanha Nacional de Educação de Adultos (STEPHANOU, BASTOS, 2005).

Na Constituição Federal de 1988, a educação é citada no Art. 205, onde diz que: 
A educação, direito de todos e dever do Estado e da família, será promovida e incentivada com a colaboração da sociedade, visando o pleno desenvolvimento da pessoa, o preparo para o exercício da cidadania e qualificação para o trabalho. (BRASIL, 1988)

Diante disso, a educação passou a ser um direito constitucional. O Direito à educação faz parte dos direitos sociais, que visam a igualdade entre as pessoas, desta forma este direito precisa ser garantido, e para isso a Lei de Diretrizes e Bases da Educação Brasileira (LDB 9394/96) foi criada para regulamentar o ensino público e privado no Brasil, na lei ficou definido os direitos que todos têm a educação, a lei não foi formulada em detalhes, sendo assim dá bastante liberdade para as escolas, o que fica bem claro na lei é que a educação é um direito de todos (BRASIL, 1996).

A Educação de Jovens e Adultos foi constituída após muitas lutas para que se tornasse obrigatório à oferta do ensino pelo poder público, conforme foi destacado pela Lei de Diretrizes e Bases - LDB que "a Educação de Jovens e Adultos é destinada para aqueles sujeitos, que por alguma razão, não conseguiram dar prosseguimento ao processo de escolarização no período regular" (BRASIL, 1996).

A educação na EJA tem como foco os alunos que não frequentaram a escola na idade certa, para oferecer um ensino de qualidade para incluir este público que busca inserção social através da educação, mas, para isto é vital que haja políticas públicas para a estruturação escolar, através da educação democrática (FERREIRA; VITORINO, 2019). Os mesmos autores relatam os aspectos que contribuíram para o avanço do EJA: 
[...] o acolhimento da EJA pela Lei de Diretrizes e Bases da Educação Nacional (LDB/1996), o que contribuiu para que essa modalidade de ensino adquirisse relativa importância e direito social. Daí surgirem estudos e pesquisas voltados para esse modelo específico de ensino, além da promoção de eventos em que profissionais atuando na EJA discutem, refletem, vivenciam e trocam experiências sobre os problemas mais evidentes nesse processo de escolarização. (FERREIRA; VITORINO, 2019, p.2)

O dever do estado é oferecer educação de qualidade para todos, crianças a partir de quatro anos até adultos que não estudaram no tempo certo, assim podemos dizer que a educação deve ser acessível a todos e para isto temos as escolas públicas.

A Educação de Jovens e Adultos (EJA) tem o objetivo de garantir o direito à educação da população com mais de 15 anos que não é alfabetizada ou não concluiu o ensino. Oliveira (1999) acredita que a modalidade é definida pela condição de exclusão econômica, social e cultural e educacional da maior parte destes alunos.

A alfabetização de jovens e adultos tem sido um grande desafio, pois a pessoa na fase adulta possui um perfil de diferente como aluno, o ensino precisa motivá-lo para que não haja a evasão escolar, assim trabalhar os conteúdos didáticos e a inteligência emocional é vital para garantir a permanência destes alunos na escola, e favorecer o aprendizado.

A psicologia torna-se importante quando auxilia os docentes na percepção nas fases que vem desde a infância até a vida adulta, onde o comportamento é alterado e obter conhecimento destes comportamentos auxilia o docente a elaborar diferentes métodos para que 
todos consigam um real aprendizado (LEGAL, DELVAN, 2009).

É necessário compreender o momento do aluno de acordo com seu desenvolvimento social e emocional e ter conhecimento de seus interesses, suas aptidões e atitudes, que influenciam diretamente na formação de sua personalidade e no rendimento escolar. O professor precisa ter ciência do nível dos alunos e ajustar o ensino, adquirir uma boa didática e ter cognição das várias abordagens da aprendizagem, pois os alunos são muito diferentes com relação a inteligência, gostos, objetivos (SILVA, 2009).

A população analfabeta e com baixa escolarização precisa que o professor tenha um papel ainda maior, pois é grande a desistência por conta de dificuldades pessoais e também de aprendizado, o docente precisa propor ações onde estimule seus alunos e os conscientizem da importância da educação.

\section{Inteligência Emocional no EJA}

As emoções estão presentes em todos os momentos da vida, nas relações pessoais e demais relações, assim se inicia o processo de socialização das emoções com a família, e posteriormente na escola, chegando ao campo da educação, sendo um processo constituído ao longo da vida (CASASSUS, 2009).

Gonsalves (2015) define a educação emocional como um processo de formação vivencial que está diretamente ligada à emoção e cognição, levando em conta a dimensão cultural, a emoção faz parte de valores, costumes e tradições, baseados no passado, presente e futuro. Existe ainda a necessidade de autoconhecimen- 
to para as diversas questões emocionais, que podem determinar as ações.

A educação emocional busca refletir a formação ao longo da vida, emoção, cognição, cultura e autoconhecimento contribuindo assim para o desenvolvimento de habilidades pessoais e sociais. Ainda sobre o tema Bisquerra (2007) afirma:

A educação emocional é um processo educativo contínuo e permanente que deve estar presente ao longo de todo o currículo acadêmico e na formação permanente durante toda a vida. A educação emocional tem um enfoque do ciclo vital, pois propõe oportunizar o desenvolvimento humano no aspecto pessoal e social. (BISQUERRA, 2007, p. 27)

Deste modo, a escola e família devem junta compreender as emoções dos alunos, utilizar a inteligência emocional como uma estratégia, compreender as necessidades afetivas das pessoas, Santos (2000) acredita que:

A educação com objetivos exclusivamente cognitivos tem se mostrado insatisfatória, pois, apesar de tantos avanços tecnológicos, da televisão, de computadores e, multimídia utilizados no processo educacional, as novas gerações têm mostrado crescente falta de competência emocional e social. (SANTOS, 2000, p. 22)

O modelo educacional atual não dispõe materiais necessários para o desenvolvimento cognitivo do estudante, com as mudanças impostas pela sociedade, a educação escolar precisa passar por diversas transformações nos processos de ensino a fim de garantir uma aprendizagem que atenda as necessidades dos alunos e da sociedade. 
O processo de educação depende da inteligência emocional, o estudante aprende quando o conteúdo se relaciona com sua vida e experiências, que possibilita maior estímulo no processo, Goleman (2012) diz que a capacidade de identificar os próprios sentimentos e de se motivar gerindo as emoções dentro de cada um, assim pode ser dividida em: consciência social, automotivação, autoconsciência, autor regulação e relacionamentos interpessoais. Carício (2016) diz que um trabalho de educação emocional aponta bons resultados como:

Aumento das habilidades sociais e das relações interpessoais satisfatórias; diminuição de pensamentos autodestrutivos, melhora da autoestima; diminuição do índice de violência e agressão; menor conduta antissocial e socialmente desordenada; menor número de expulsões de sala de aula; melhora do rendimento acadêmico; diminuição da iniciação para consumo de drogas (álcool, cigarro, drogas ilegais); melhor adaptação escolar, social e familiar; diminuição da tristeza e sintomas depressivos; diminuição da ansiedade e stress; diminuição das desordens relacionadas com a alimentação. (CARÍCIO, 2016, p. 62)

Assim, percebe-se como é essencial o trabalho da educação emocional no âmbito escolar trazendo resultados para o processo de ensino e aprendizagem, e o conhecimento das próprias emoções, devendo a escola ser um espaço de conexão emocional. Goleman (2012) acredita que na educação de jovens e adultos a inteligência emocional é ainda mais importante, isto porque cada um tem sua história de vida, e precisa saber trabalhar e controlar as emoções, e conseguir ter um bom relacionamento e aprender. Com a necessidade de 
realizar o ensino de forma remota, se torna vital o trabalho da inteligência emocional, uma vez que diversos sentimentos tomam conta do aluno, inclusive a vontade de desistir.

\section{O Ensino Remoto no EJA}

Com a necessidade de aderir às aulas remotas, vieram diversas dificuldades, o acesso não é para todos os alunos uma vez que nem todos tem acesso a internet que atenda a necessidade ou não possuem aparelhos que comportem programas, assim o desafio do EJA é superar um momento difícil, e reforçar os vínculos dos educandos com a cultura escolar, assim a pandemia intensificou a exclusão dos alunos do EJA, uma vez que muitos sentiram grande dificuldades para continuar os estudos, sendo dificuldades de acesso às aulas, ou problemas pessoais, como o medo e estresse, falta de emprego, cuidado da casa e dos filhos, etc (COLEMARX, 2020).

Muitos professores também não possuem conhecimento nem suporte tecnológico para as aulas online, desenvolvendo uma educação de qualidade, assim, uma sociedade que já é desigual, aumentou o processo de exclusão na escola (COLEMARX, 2020).

O uso de tecnologias no ensino remoto é complexo, pois a maior parte dos estudantes não possui experiência com plataformas digitais, apesar de utilizar redes sociais, não possuem domínio das tecnologias digitais para serem utilizados da forma que o ambiente de estudo exige (OLIVEIRA, 2020). Analisando outros aspectos as pessoas estão passando por momentos ainda mais difíceis durante a pandemia, faltam alimentos, água potá- 
vel, condições dignas de moradia, e todos estes fatores favorecem ao abandono escolar (COLEMARX, 2020).

As questões de evasão escolar tiveram um aumento significativo com o ensino remoto, o que demonstra a necessidade de investir em tecnologias educacionais para preparar os alunos para compreender e aprender a utilizar os meios tecnológicos disponíveis (FIORI; GOI, 2020). O ensino do EJA foi bastante afetado com a adesão ao ensino remoto que não atendeu a maioria dos alunos "muitos no Brasil não têm acesso a computadores, celulares ou à Internet de qualidade, realidade constatada pelas secretarias de Educação de Estados e municípios no atual momento" (DIAS; PINTO, 2020, p. 546).

Os docentes tirem pouco tempo para aprender a utilizar as plataformas digitais, sendo preciso obter conhecimento para inserir atividades online, gravar vídeos, avaliar os estudantes, preparar conteúdos que auxiliem os alunos a compreender as aulas remotas (DIAS; PINTO, 2020).

Os docentes vêm demonstrando preocupação com a evasão escolar, pois, os números já são altos, e com o distanciamento da escola e as aulas remotas se acredita que a evasão será ainda maior. Com isto já se pensa em novas medidas para combater o abandono no retorno das aulas presenciais, apesar de não haver ainda dados oficiais, os professores identificam que os alunos que participam dos conteúdos remotos são menos que a metade (EJA, 2020).

De acordo com Lencastre (2021) existem escolas com $100 \%$ de evasão nos cursos do EJA no Estado do Rio Grande do Sul, pois, muitos alunos não possuem acesso à internet, e ainda precisam trabalhar para garantir o sustento da família. Assim o ensino remoto não vem 
sendo eficaz, pois, maior parte dos alunos do EJA são pessoas que não possuem habilidades e nem acesso a tecnologias, com isto o ensino fica prejudicado, esperando que ocorra o retorno das aulas presenciais, e que estes alunos retornem às escolas.

\section{Desafios dos docentes e discentes durante o Ensino Remoto}

O ensino remoto vem sendo um grande desafio para alunos e professores, Dayrell (1996) diz que os alunos possuem saberes e culturas diferentes, que decorre da experiência de vida de cada um. O estudo para este público é uma escolha consciente, que decorre da necessidade de adquirir maior conhecimento por conta do mercado de trabalho, como por realização pessoal. Para haver uma aprendizagem efetiva é preciso considerar o aluno em sua totalidade, possibilitando a construção do novo através do saber, com isto se resgata o papel ativo dos sujeitos, na vida social e escolar (DAYRELL, 1996).

Com o distanciamento social foi inevitável aderir às atividades remotas, mesmo o sistema educacional não estando preparado para isto. O Conselho Nacional de Educação - CNE 2020 fez recomendações para o Ensino de Jovens e Adultos, onde diz que:

Enquanto perdurar a situação de emergência sanitária, as medidas recomendadas para EJA devem considerar as condições de vida dos estudantes, para haver harmonia na rotina de estudos e de trabalho. As aulas, portanto, devem ser transpostas do modo presencial para o ensino remoto, no caso da EJA. De modo que as atividades pedagógicas não presenciais (APNP) devem priorizar os meios digitais, evitando implicar em deslocamento físico ou presencial, com objetivo de ga- 
rantir o distanciamento social que visa proteger a vida e a saúde de integrantes da comunidade acadêmica e de seus familiares (BRASIL, 2020).

As atividades pedagógicas não presenciais devem ter foco no apoio emocional, voltadas à inteligência emocional, a fim de prestar assistência aos alunos em um momento difícil, assim é preciso considerar as vulnerabilidades dos estudantes, compreendendo suas dificuldades a fim de evitar o aumentos das desigualdades, com isto as escolas devem mediar meios que possibilitem aos alunos o acesso ao material de estudo e orientação dos professores.

São grandes os desafios dos professores na educação de jovens e adultos, a evasão e falta de interesse é o principal desafio, o professor precisa criar no aluno o interesse em aprender, ou ela não permanecerá na escola, em conjunto a isto a falta de materiais didáticos e equipamentos que possibilitem planejar uma aula mais dinâmica é frequente no ensino do EJA.

Os educadores precisam buscar caminhos que favoreçam a aprendizagem, pois manter os alunos na escola é tarefa complicada, muitos apresentam dificuldades por conta de outras atividades do dia a dia, como trabalho, família, filhos, atividades domésticas. Di Pierro (2010, p. 35) explica essa dificuldade:

[...] os jovens e adultos analfabetos ou com baixa escolaridade não ocorrem com maior frequência às escolas públicas porque a busca cotidiana dos meios de subsistência absorve todo seu tempo e energia; seus arranjos de vida são de tal forma, precários e instáveis que não se coadunam com a frequência contínua e metódica à escola; a organização da educação escolar é demasiadamente rígida para ser compatibilizada com os modos de 
vida dos jovens e adultos das camadas populares; os conteúdos veiculados são pouco relevantes e significativos para tornar a frequência escolar atrativa e motivadora para pessoas cuja vida cotidiana já está preenchida por compromissos imperiosos e múltiplas exigências sociais (DI PIERRO, 2010, p.35).

Assim, as maiorias destes alunos abandonam a escola para se dedicar ao trabalho, uma vez que necessitam manter o seu sustento e da família, e diante disso o professor não tem como interceder uma vez que as condições sociais e econômicas são mais fortes que o desejo de estudar.

Os docentes devem enfrentar os desafios e desenvolver canais de comunicação com os estudantes, no estado do Pernambuco dentre as ações realizadas foi criado um espaço no portal da Secretaria de Educação, com atividades para que os alunos realizem em casa, mas, devido à falta de acessibilidade dos alunos muitos não possuem acesso (CASASSUS, 2009).

Com isto, é preciso utilizar a inteligência emocional para superar hábitos negativos, oferecer apoio aos alunos a fim de que possam aproveitar o potencial, e superar este momento onde aumentou as desigualdades sociais, e afastaram jovens e adultos das escolas. A escola é uma organização social e emocional, devendo sempre valorizar as emoções, Casassus (2009) diz que a escola é uma organização de um sistema de relações que se estruturam para aprendizagem fundamentada na emoção.

\section{Metodologia}

Este estudo trata-se de uma revisão da literatura, que é definido por autores como: "A revisão de litera- 
tura resultará do processo de levantamento e análise do que já foi publicado sobre o tema e o problema de pesquisa escolhidos" (SILVA; MENEZES, 2001, p. 37). Com isto se busca a problematização de um projeto de pesquisa com o estudo de referências publicadas, assim serão analisadas as contribuições cientificas sobre o tema.

Este artigo propõe uma reflexão sobre a importância da inteligência emocional na educação de jovens e adultos durante o ensino remoto, identificando os desafios do ensino a distância para os adultos, e de qual forma influenciou na aprendizagem.

Para levantamento dos artigos foi realizado busca online, usando os seguintes descritores (Decs): Inteligência emocional na educação; EJA no ensino remoto; Ensino de jovens e adultos na pandemia. Como fontes de pesquisa utilizaram-se documentos encontrados em base de dados confiáveis como a Scielo, Lilacs, Bibliotecas Virtuais.

Realizou-se o estudo do material encontrado a fim de obter maior conhecimento sobre o tema, realizando leitura dos artigos, com isto foi possível selecionar os que atendiam os objetivos da pesquisa, possibilitando maior compreensão do tema, para realização do trabalho proposto.

No decorrer da pesquisa iremos contextualizar a educação de jovens e adultos, a importância da inteligência emocional no ensino remoto, uma vez que afetaram aos alunos, principalmente aqueles que não estão familiarizados com as tecnologias, apresentando maior dificuldade de adaptação ao método. E por fim iremos discorrer sobre os principais desafios enfrentados por professores e alunos para realização do ensino a distância. 


\section{Resultados e Discussões}

A Educação de Jovens e Adultos se difere das demais, pois visa atender as pessoas que não realizaram os estudos no tempo adequado, e com a necessidade diante das exigências do mercado de trabalho, ou para realização pessoal resolver voltar para a escola, diante disso os docentes devem organizar os conteúdos voltados para este público. O ensino precisa ter relação com as experiências e anseios dos alunos, para que haja um aprendizado efetivo.

Com a suspensão das aulas presenciais é o ensino remoto sendo instituído para que haja continuidade nos estudos os alunos da EJA ficaram prejudicados, observa-se que grande parte dos alunos não possuem equipamentos adequados para as aulas online, e nem acesso a internet de qualidade, além de não possuírem conhecimento adequado para utilização das plataformas.

Diante deste cenário, os docentes precisam compreender as dificuldades dos alunos e atuar no campo da inteligência emocional, criar uma relação mais próxima com os alunos, compreendendo o momento em que todos estão vivendo, a fim de mantê-los motivados para retornar à escola quando for possível. No momento de medos e incertezas, muitos alunos desistem das aulas, acreditam que não aprenderam, ou que não vale a pena se dedicar aos estudos diante dos problemas causados pela pandemia.

É vital que a escola busque identificar como se encontra cada aluno, e quando não for possível passar conteúdos pedagógicos, agir no campo da inteligência emocional, oferecendo suporte, para que os mesmos não desistam dos objetivos. 
A educação sofreu grandes prejuízos, pois os docentes não estavam preparados para a nova modalidade de ensino, e o Brasil possui um alto número de pessoas que não dominam as tecnologias, outro fator que agrava a situação é a desigualdade social, onde os alunos principalmente de escolas públicas não possuem celulares, computadores, e acesso a internet, o que inviabiliza a aprendizagem no ensino remoto.

\section{Conclusão}

A pesquisa realizada possibilitou maior compreensão sobre a Educação de Jovens e Adultos, quando surgiu e como vem sendo oferecida nas escolas do Brasil, e enfrentam diariamente grandes desafios, pois os docentes precisam elaborar aulas que venham motivar os alunos.

Identificou-se que a inteligência emocional é essencial para aprendizagem, isto porque os alunos possuem emoções, e sendo adultos já vivenciaram mais coisas e sentimentos, e diante disso é preciso estudar e compreender as emoções, a fim de obter maior controle emocional, favorecendo na sua vida pessoal e na aprendizagem.

Com a implantação do ensino remoto no período de pandemia, diversos alunos desistiram dos estudos, isto porque possuem dificuldades para ter acesso aos conteúdos, não possuem equipamentos adequados, e ainda sentem-se desmotivados, diante das diversas emoções que este período vem proporcionando como o medo, angústia, incertezas, problemas financeiros e de saúde.

Desta forma, os docentes precisam oferecer apoio emocional aos seus alunos, tentando manter um víncu- 
lo para que ao retorno das aulas eles voltem às escolas, pois, apesar de todo esforço das escolas muitos alunos já abandonaram os estudos, e será preciso realizar ações para que os alunos retornem.

Conclui-se que o distanciamento dos alunos das salas de aula será um grande retrocesso no processo de aprendizagem, sendo necessária a realização de políticas públicas para que estes alunos voltem à sala de aula para completar o processo de aprendizagem.

\section{Referências}

BISQUERRA, Rafael; ESCODA, Nuria Perez. Las Competencias Emocionales. Educación XXI, Universidad Nacional de Educación a Distancia Madrid, España, v. 10, p. 61-82, 2007.

BRASIL. Constituição (1988). Constituição da República Federativa do Brasil. Brasília, DF: Centro Gráfico, 1988

BRASIL. Lei de Diretrizes e Bases da Educação Nacional (LDB) 9394/1996. São Paulo: Saraiva, 1996.

BRASIL. Resolução CNE/CP no 2, de 10 de dezembro de 2020. Diário Oficial da União: seção 1, Brasília, DF, edição 237, p.52, $11 \mathrm{dez}$. 2020. Disponível em: https:// www.in.gov.br/en/web/dou/-/resolucao-cne/cp-n-2-de-10-de-dezembro-de-2020-293526006. Acesso em: 29 jul.2021.

CARÍCIO, Márcia Rique. Educação Emocional e Enfermagem: contribuição para um Ato de Trabalho Integral e Afetuoso na Saúde. In: II Congresso Internacional de Educação Inclusiva, CINTEDI, Anais..., João Pessoa, UFPB. p. 1-12, 2016. Disponível em: http://editorarealize.com.br/editora/anais/cintedi/2016/TRABALHO_ EV060_MD1_SA10_ID4093_22102016210111.pdf. Acesso em: 29 jul.2021. 
CASASSUS, Juan. Fundamentos da Educação emocional. Brasília: UNESCO, Liber Livro Editora, 2009.

COLEMARX. Coletivo de Estudos em Marxismo e Educação. Em defesa da educação pública e comprometida com a igualdade social: Por que os trabalhadores não devem aceitar aulas remotas?. Rio de Janeiro: Colemarx, 2020. Disponível em: https://esquerdaonline. com.br/wp-content/uploads/2020/04/Colemarx-texto-cr\%C3\%ADtico-EaD-vers\%C3\%A3o-final-b-1.pdf. Acesso em: 29 jun. 2021.

DAYRELL, J. T. A escola como espaço sócio-cultural. In: Dayrell, J. (Org.). Múltiplos olhares sobre educação e cultura. Belo Horizonte: UFMG, 1996.

DIAS, Érika; PINTO, Fátima Cunha Ferreira. A educação e a covid-19. Ensaio: Aval. Pol. Pub. Educ., Rio de Janeiro, v. 28, n. 108, p. 545-554, jul./set., 2020.

DI PIERRO, Maria Clara. Balanço e desafios das políticas públicas de educação de jovens e adultos no Brasil. In: SOARES, Leôncio et al. (Org.). Convergências e tensões no campo da formação e do trabalho docente. ENDIPE, 15. Belo Horizonte: Autêntica, 2010.

FERREIRA, Edna Maria de Oliveira; VITORINO, César Costa. Passageiros da noite: do trabalho para a EJA. Itinerários pelo direito a uma vida justa. Resenha, Revista Brasileira de Educação, v. 24, Rio de janeiro, 2019.

FIORI, R.; GOI, M. E. J. O ensino de Química na plataforma digital em tempos de Coronavírus. Revista Thema. Edição Especial. v.18, pp. 218-242. Disponível em: http://periodicos.ifsul.edu.br/index.php/thema/article/view/1807/1570. Acesso em: 29 jul. 2021.

GOLEMAN, Daniel. Inteligência Emocional: a teoria revolucionária que redefine o que é ser inteligente. 2 ed. Rio de Janeiro: Objetiva, 2012. 
GONSALVES, E. P. Educação e emoções. Campinas: Alínea, 2015.

LEGAL, José Eduardo e DELVAN, Josiane da Silva. Psicologia do desenvolvimento e aprendizagem. Indaial, SC: ASSELVI, 2009.

LENCASTRE, Carla. Pandemia de abandono e evasão escolar. 2021. Disponível em: https://projetocolabora. com.br/ods4/pandemia-de-abandono-e-evasao-escolar/. Acesso em: 29 jul. 2021.

LIMA, Walkíria dos Reis; PIRES, Luciene Lima de Assis; SOUZA, Paulo Henrique de. A educação de jovens e adultos, o educando e o contexto da pandemia. Dossiê - Educação brasileira e a EAD no contexto da pandemia de Covid-19. Volume 16. 2020. Disponível em: https://www.scielo.br/pdf/rbedu/v24/1809-449X-rbedu-24-e240007.pdf Acesso em: 29 jul. 2021

LOPES, Selva Paraguassu; SOUZA, Luzia Silva. EJA: uma educação possível ou mera utopia? CEREJA. 2010. Disponível em: http://forumeja.org.br/ac/book/export/html/61. Acesso em: 29 jul. 2021.

OLIVEIRA, Fabiane Lopes de. Educação transformada em EAD durante a pandemia: quem está por trás dessa ação? In: AUGUSTO, Cristiane Brandão; SANTOS, Rogerio Dutra (Orgs.). Pandemias e pandemônio no Brasil. São Paulo: Tirant lo Blanch, 2020. p. 247-260. Disponível em: http://www.unicap.br/catedradomhelder/wp-content/uploads/2020/05/Pandemias-e-pandemo\%CC\%82nio-no-Brasil.pdf $>$. Acesso em: 29 jul.2021

OLIVEIRA, Marta Kohl de. Jovens e Adultos como Sujeitos de Conhecimento e Aprendizagem. Revista Brasileira de Educação, n. 12, p. 59-73, set./dez, 1999. Disponível em: http://eixovpsicologia.pbworks.com/f/texto+6.pdf. Acesso em: 29 jul.2021. 
PALÚ, Janete; SCHÜTZ, Jenerton Arlan; MAYER, Leandro (Orgs.). Desafios da educação em tempos de pandemia. Cruz Alta: Ilustração, 2020. 324p.

SANTOS, Jair de Oliveira. Educação Emocional na Escola: a emoção na sala de aula. 2. ed. Salvador, 2000.

SILVA, Edna Lúcia da: MENEZES, Estera Muszkat. Metodologia da pesquisa e elaboração de dissertação. 3 ed. Florianópolis: Laboratório de Ensino a Distância da UFSC, 2001.

SILVA, João Alberto da. O sujeito psicológico e o tempo da aprendizagem. Cadernos de Educação. Pelotas, RS, p. 229-250, jan./abr. 2009. Disponível em: http://www2. ufpel.edu.br/fae/caduc/downloads/n32/13.pdf. Acesso em: 29 Jul. 2021.

STEPHANOU, Maria; BASTOS, Maria Helena (orgs). Histórias e Memórias da Educação no Brasil. Vol. III. Petrópolis: Vozes, 2005.

VENTURA, Jaqueline P. Educação de Jovens e Adultos Trabalhadores no Brasil: revendo alguns marcos históricos. 2011. Disponível em: http://ppgo.sites.uff.br/ wpcontent/uploads/sites/296/2017/12/educacao-jovens-adultos-trabalhadores-revendomarcos.pdf. Acesso em: 29 jul.2021. 


\title{
OS DESAFIOS DA GESTÃO ESCOLAR NO ENSINO REMOTO DURANTE O PERÍODO PANDÊMICO
}

\author{
Natália Maria Martins Moreira \\ Sheyla Maria Mota Meireles² \\ Sílvia Helena Linhares Coelho da Silva ${ }^{3}$ \\ Luciana Mascena Silva ${ }^{4}$
}

\section{Introdução}

No mês de março do ano de 2020, fomos surpreendidos pela pandemia do COVID-19, o que trouxe a convocação de adentrarmos em territórios nunca antes visitados pela nossa geração. $\mathrm{O}$ isolamento social e as incertezas com relação ao futuro nos afetaram de variadas formas e nos diversos campos de relações humanas. A humanidade teve que buscar estratégias diferentes para fazer acontecer o que não podiam esperar, e a educação era uma delas. A Educação teve que assumir novas falas, ouvir novas vozes, fazer uso de novas ferramentas e continuar. O educar não podia esperar. Esse verbo que jamais pode deixar de ser conjugado e em 2020 ele não foi. Foram muitas emoções, muitos sentimentos, desafios,

1 Graduada em Pedagogia - UVA; Especialista em Educação Inclusiva - Universidade Salgado de Oliveira RJ, Especialista em Atendimento Educacional Especializado - UVA; Especialista em Gestão Escolar - Faculdade Maciço de Baturité; Coordenadora escolar do Município de Maracanaú/CE; E-mail: natymoreira37@gmail.com

2 Bacharel em Ciências Contábeis - UVA; Técnica em Secretaria escolar e Empresarial; Secretária escolar do município de Maranguape/CE; E-mail: sheylameirelesmota17@gmail.com

3 Graduada em Serviço Social - Universidade Anhanguera; Coordenadora administrativa financeira do município de Maracanaú/CE; E-mail: silvialinharescoelho@gmail.com

4 Graduada em Biologia - UVA; Especialista em Auditoria ambiental - CENTEC; Mestra em Ciências Morfofuncionais - UFC; E-mail: lumascena2@gmail.com 
mas também muitas vitórias e conquistas. Muitas aprendizagens, competências e habilidades foram percebidas, fora dos pareceres da convencionalidade e outras mais, que só descobriremos, sentiremos, posteriormente. Mas, quem apostaria que o ano de 2021 chegaria assim? Nunca foi tão desafiador iniciar um ano letivo como esse decorrente. Porque aqui estamos e somos privilegiados em poder continuar nossa luta diante de tantos que ficaram para trás. Estamos mais experientes, mais potentes, mais lúcidos diante do enorme desafio de fazer chegar aos lares dos estudantes a nossa voz, e com isso fazer uso das ferramentas como recursos que até então não tínhamos intimidade e o que se parecia distante, está posto. Muitas ainda são as incertezas, as desigualdades, que permeiam nosso cenário, mas sigamos nos movendo e fazendo mover-se, acreditando que o nosso trabalho faz a diferença na vida de muitos educandos e de muitas famílias, pois as adversidades existem, cabe a nós educadores elaborar estratégias de acordo com a realidade da comunidade escolar, possibilitando o acesso aos estudantes (CAMBI, 2020).

Todos foram impactados pela pandemia do $\mathrm{CO}-$ VID-19, de diferentes maneiras, inclusive a gestão escolar, com nossa saúde mental abalada dado ao isolamento social, com a incapacidade de lidar com o desconhecido, o medo, a tristeza, a insegurança, a ansiedade, a angústia e as incertezas. E como manter a boa saúde mental e ter equilíbrio/inteligência emocional diante do quadro onde nos encontrávamos seria uma luta diária. Vivíamos num constante desafio (GRANDISOLI, JACOBI e MARCHINI, 2020).

Como ter tranquilidade e equilíbrio para dar aos professores que tinham tantas incertezas de como 
seria repassar sua aula diária, seus conhecimentos através de um aplicativo de celular, pois não lhes foi ensinado nos bancos de faculdade essa metodologia de ensino. Esses profissionais necessitavam de nosso direcionamento com bastante equilíbrio/inteligência emocional, pois esse novo modelo de ensino conduzido pela tecnologia era inovador, e muitos tem medo do desconhecido. Como faríamos com os alunos que não iriam participar dos grupos do aplicativo do celular, já que a aula aconteceria, mesmo que de forma remota. No entanto, nem todas as famílias teriam condições financeiras de manter um serviço de internet em suas casas. E assim de acordo com a sua condição social, o aluno seria o mais prejudicado, não podendo assim dar continuidade a seus estudos, pois a desigualdade social sempre existiu, só que na pandemia infelizmente ela aflorou ficando a cada dia mais acentuada. A cada vez que uma família nos procurava com todas as suas questões de vulnerabilidade social, desassistida pelas políticas públicas, impossibilitada de responder às necessidades básicas de seus membros, reverbera nas salas de aula mesmo que remota, e tínhamos que respirar fundo e tentar encontrar saídas para esse aluno não ser ainda mais prejudicado do que já o é.

Como ter equilíbrio emocional, se nós enquanto gestão, somos pessoas que também sofremos, perdemos amigos e parentes para essa doença, também fomos arrancados de nossas atividades, do nosso cotidiano. Mas nós precisávamos ter uma boa saúde emocional, pois se olhássemos para os nossos professores e alunos com suas famílias, eram em nós que eles buscavam referências e a educação mesmo que online tinha que chegar para cada aluno com ou sem acesso, numa 
tentativa de encontrar soluções para uma educação de qualidade que é o nosso papel enquanto gestores (MATIAS e TEIXEIRA, 2012).

\section{Adversidades enfrentadas no ensino remoto}

A pandemia COVID-19 trouxe para alunos e professores um sentido de urgência e adaptação. Devido aos novos desafios, a necessidade maior é de estabelecer uma junção entre a rotina de isolamento e a continuidade do ensino. Por mais importante que o ensino remoto seja na atual situação, apresenta graves limitações e não atende a todos os alunos da rede pública (FERREIRA e SANTOS, 2021).

Por meio da disponibilização de plataformas online, aulas ao vivo em redes sociais e envio de materiais digitais aos alunos, essas técnicas estão a serviço de muitas limitações sociais, estruturais e econômicas, que prejudicam o aprendizado dos alunos e comprometem a eficiência do ensino desenvolvido pelas instituições. Infelizmente, foram muitos desafios: escolas fechadas desde meados de março, professores sem formação para o trabalho remoto, estudantes que não têm computadores, ou outro equipamento em casa, a falta de acesso à internet na casa de estudantes e, até, de professores, entre outros (SANTOS e ZABOROSKI, 2020).

Algumas dificuldades e desafios que permeiam também o ensino a distância atualmente, é possível destacar o resultado emocional nos alunos e profissionais da Educação, o abandono e evasão escolar pela falta de recursos aptos ao estudo nas residências dos respectivos alunos, as dificuldades enfrentadas por estudantes de zonas rurais, entre outros. 
Na obra de Manzotti (2021), é enfatizado que enfrentar essa pandemia é um desafio constante: isolamento social, medo e ameaça da doença, convívio com a ideia de morte. Não é uma situação fácil para ninguém, porém, os estudantes e professores precisam, ainda, adaptar-se a uma nova dinâmica de ensino em suas próprias residências, com pessoas do outro lado da tela e com os amigos e colegas distantes.

O grande problema é que muitos alunos apresentam uma grande dificuldade em conciliar o lazer e o estudo não presencial, atingindo em uma defasagem de aprendizado que está intimamente ligado a doenças como depressão e ansiedade, e muitos ainda não tem o incentivo da família prejudicando cada vez mais a aprendizagem dos mesmos. Os professores, por outro lado, têm de procurar relacionar sua vida profissional com as atribuições familiares e domésticas. Muitos precisam, ainda, auxiliar seus filhos que estão estudando em casa, ao mesmo tempo em que lecionam para outros estudantes, causando uma sobrecarga bastante considerável, que só aumenta a tensão causada pela pandemia.

Com o ensino remoto a situação é, ainda, mais preocupante, pois segundo (ZAJAK, 2020), apenas $42 \%$ das casas brasileiras tem computador; $85 \%$ dos usuários de internet das classes $\mathrm{D}$ e $\mathrm{E}$ acessam à rede exclusivamente pelo celular e somente $13 \%$ se conectam tanto pelo aparelho móvel quanto pelo computador.

Se nas cidades o ensino remoto vem se mostrando, no mínimo, desafiador devido a dificuldades econômicas, familiares e estruturais, o que comentar das áreas rurais, onde, muitas vezes, os serviços de internet $\mathrm{e}$ telefonia não existem. São questões muito pertinentes 
que preocupam milhares de famílias, na zona Rural. Sem contar também na dificuldade que muitos estão passando financeiramente, sem empregos, muitas pessoas com a pandemia perderam seus empregos, devido a algumas empresas que também sofrem com toda essa situação que estamos vivendo.

Mesmo com todas as tribulações em comunidades sem acesso à internet, os alunos estão recebendo conteúdo didático e listas de atividades para ser feitas em casa. Entretanto, apesar dos esforços, é nítido que haverá uma grande perda curricular destes estudantes, que partirão com uma severa desvantagem em concursos e vestibulares. Nos anos de 2019 a 2021 com a COVID-19 alguns alunos que se preparavam para o vestibular, já se sentiram prejudicados, abalados com a situação de ter que adiar datas para a realização do mesmo. Com a quarentena e o isolamento social, no que afasta os instrumentos educacionais dispostas hoje com a ajuda dos meios compartilhados. Além disso, a discussão sobre o papel do professor e do profissional psicopedagogo dentro Escolas tem-se tornado, ainda mais, decisiva para desenvolver um lecionar mais humanitário e preocupado com as particularidades de cada indivíduo (professor - aluno). O mais importante, agora, na atual situação, é identificar tais prejuízos e trabalhar duro para um desenvolvimento em conjunto de todo o sistema educacional, focando a aprendizagem de nossos alunos (SANTOS e ZABOROSKI, 2020).

\section{Relatos de experiências no período de pandemia}

O presente relato de experiência está sendo vivenciado pela Educação de Maranguape nesse período de 
pandemia. Desta forma, a equipe do Núcleo de Gestão Escolar da SME, acreditando que uma educação de qualidade se faz de forma participativa e integrada, resolveu elaborar um projeto que possibilitará maior acompanhamento de forma presencial, para conhecer de perto a realidade e necessidade das unidades escolares.

Onde tem vigência de quatro anos, as visitas acontecerão de seis em seis meses, por ser um trabalho minucioso, intensificado com coletas de informações completas. Nesse encontro, será analisado todo o contexto escolar e finalizado com plano de ação para o semestre.

O título do Projeto Delivery às Unidades Escolares - DUE se deu a partir da importância do significado do nome Delivery e entrega. E isso é exatamente o que a SME se propõe: sair do seu local de trabalho para ir ao encontro das escolas, levando apoio e conhecimento técnico para potencializar o trabalho. Tornando-o ainda mais consistente e eficaz, ouvindo, planejando, aprendendo com toda comunidade escolar. Assim obteremos resultados positivos e fazendo valer o slogan "Maranguape nosso orgulho, nosso amor".

O retorno às aulas já está sendo cogitado, e isso exigirá das escolas um planejamento mais cauteloso no tocante à saúde, mais criativo, inovador e humano. Tudo terá que acontecer de forma gradual, será preciso modificar toda rotina administrativa e pedagógica, organizar calendário e adequar os espaços escolares. A escola precisa estar informada para tomar todas as precauções conforme protocolo oferecido pelos órgãos competentes.

Daí surge o motivo da criação deste projeto, o momento se faz necessário, as escolas estão fragilizadas, precisando de apoio, precisando de todas as informa- 
ções possíveis para um retorno seguro, e o Núcleo de Gestão Escolar irá até elas, para dar esse suporte, conhecendo de perto a realidade de cada uma, ouvindo suas necessidades, reorganizando todo o trabalho para que esse retorno aconteça com segurança e de forma eficaz.

Assim, temos como objetivo, a realização de um trabalho democrático intensificando, laços de confiança e afetividades com as escolas, como também objetiva promover ações Inter setoriais com todas as unidades escolares.

Estão sendo realizados encontros com todas as escolas para avaliar e alinhar as ações executadas durante os meses. O Projeto DUE tem tido uma excelente aceitação por parte dos Professores e Gestores das Escolas Municipais, é um apoio a toda comunidade escolar onde se encontram todos fragilizados e abalados com as consequências dessa pandemia.

O relato de experiência a seguir está sendo realizado na EMEIEF Manoel Rodrigues Pinheiro de Melo nesse período de pandemia. Desta forma a gestão juntamente com os professores desenvolvem um plano de ação, esperar não é saber. O futuro é presente! Que possibilitará o acompanhamento e a participação de forma não presencial dos alunos no processo de aprendizagem das aulas remotas.

Apresentar alternativas de estudos à nova proposta curricular para que escola e família possam participar e realizar as atividades de modo não presencial. Aproveitar o potencial de comunicação do universo digital e promover novos modos de aprendizagens, havendo interação professor e aluno de acordo com a realidade da nossa comunidade escolar. 
Ainda estamos no período de isolamento social, o que nos limita a chegar até nossos alunos. Desta feita, seguimos procurando alternativas que nos façam continuar seguindo com nosso trabalho. Assim os próximos períodos, nos possibilitam pensar nas temáticas onde a Cultura e as formas que estamos encontrando de conviver com os desafios de hoje incremente nosso trabalho. Apresentação das ações norteadoras que estão acontecendo neste período de isolamento social.

Entre elas, é possível citar: Criações das mídias sociais da escola, tais como Facebook, Instagram e canal do Youtube. Aulas remotas acontecem via grupos de WhatsApp, utilizando-se os seguintes recursos: videoaulas, vídeo chamada, áudios explicativos, Google Forms, Quiz, Podcast, card e Google Meet. As atividades planejadas e desenvolvidas são apresentadas de acordo com a realidade dos nossos estudantes, havendo sempre a interação e o incentivo dos professores e gestão. As devolutivas acontecem através de fotos, áudios, vídeos curtos e cartazes online. Construção de atividades impressas complementares mensais para as turmas da Creche, Educação Infantil, e Apostilas alfabetizadoras de Língua portuguesa e matemática para as turmas de 10 e 20 Anos como suporte pedagógico no processo de aquisição da leitura e escrita.

Outras ações norteadoras neste período de pandemia são a potencialização das plataformas digitais da escola, utilização de softwares para melhoria das aulas nos grupos, tornando-se mais atrativas. Além da construção de atividades de valorização das famílias em seus diferentes modelos e formatos, Projeto Família e Escola: Mãos que constroem, construções de elementos comparativos entre atividades passadas e atuais, in- 
centivam a pesquisa e leituras, assim como diversas leituras de mundo que podemos ter. Reunião de pais em horários alternativos no turno da noite, atividades de exploração a temática e projetos Valores na Educação Infantil, Olimpíadas 2021, Festejos juninos, Folclore a cultura de um povo, Semana da pátria Acaracuzinho, um pedacinho do meu Brasil, Web Lendo projeto de leitura e escrita entre outros, Agenda institucionalizada, entre outros.

Com relação à formação continuada, é possível destacar: O ensino híbrido: Conceitos e possibilidades, Profa. Joquebede Cacau; Metodologias Ativas: Conceitos e Possibilidades no ensino remoto, Profa. Alana Carvalho; Busca ativa via mensagens celular, ligações e visitas in loco aos alunos ausentes; Semana de atividades avaliativas nos grupos de whatsapp e impressa contemplando aos alunos que não tem acesso à internet; Culminância das atividades de acordo com as Temáticas em estudos tudo acontece de forma remoto.

\section{Considerações finais}

O presente artigo teve como premissa os efeitos devastadores da pandemia do Covid 19 e os desafios da educação no Brasil. Nele pode-se observar relatos exitosos de experiências vivenciadas pelas autoras e seus pares apesar de todos os obstáculos enfrentados pelo ensino remoto nesse período pandêmico com um prejuízo da aprendizagem sendo assustador. As autoras que trabalham em duas cidades próximas, com problemas sociais semelhantes, porém cada uma com suas especificidades nos trazem como a gestão educacional criou cada uma a sua maneira para atender a suas demandas, estratégias de orientação aos professores, aos alunos e 
também aos pais, como forma de mitigar a dor e vencer essa pandemia, instituindo um elo entre a rotina do isolamento e a continuidade do ensino. $\mathrm{E}$ embora com suas limitações técnicas, sociais, estruturais, econômicas e com o impacto emocional nos alunos e profissionais da educação, a gestão educacional, com o leme na mão não se furtou de seu papel e com a resiliência, que é nata do ser humano, cuidou da classe docente dando suporte emocional e técnico, buscou se reinventar em caráter emergencial, levando a educação de forma remota e ou através de atividades impressas na escola realizando a busca ativa in loco, fazendo do nosso aluno o protagonista de todo o processo ensino aprendizagem.

\section{Referências}

CAMBI, E. (2020). Pandemia da Covid-19: reflexões sobre a sociedade e o planeta. Ministério Público do Estado do Paraná, Escola Superior do Ministério Público do Estado do Paraná. Disponível em: 〈https://escolasuperior.mppr.mp.br/arquivos/Image/publicacoes/PandemiadaCovid-19Reflexoes_sobreasociedadeeoplaneta. pdf . Acesso em: 21 de setembro de 2021.

GRANDISOLI, E.; JACOBI, P. R.; MARCHINI, S.; (2020). Educação e pandemia: desafios e perspectivas. Disponível em: 〈https://jornal.usp.br/artigos/educacao-e-pandemia-desafios-e-perspectivas/>. Acesso em: $21 \mathrm{de}$ setembro de 2021.

MATIAS, I. H.; TEIXEIRA, S. M. (2012). Famílias Vulneráveis como Expressão da Questão Social e à Luz da Política de Assistência Social. Revista INTERFACE-UFRN/ CCSA ISSN Eletrônico 2237-7506, v. 9, n. 2.

FERREIRA, S. F., SANTOS, A. G. M. DIFICULDADES E DESAFIOS DURANTE O ENSINO REMOTO NA PAN- 
DEMIA: UM ESTUDO COM PROFESSORES DO MUNICÍPIO DE QUEIMADAS - PB. Revista Científica Semana Acadêmica. Fortaleza, ano MMXXI, №. 000207, 26/04/2021. Disponível em: 〈https://semanaacademica.org.br/artigo/dificuldades-e-desafios-durante-o-ensino-remoto-na-pandemia-um-estudo-com-professores-do> Acessado em: 21/09/2021.

SANTOS, J. R, ZABOROSKI, E. 2020. Ensino Remoto e Pandemia de CoViD-19: Desafios e oportunidades de alunos e professores. Interacções, v. 16, n. 55, p. 41-57.

ZAJAK, D. (2020) Ensino Remoto na Educação Básica e COVID-19: um agravo ao Direito à Educação e outros impasses. EPUFABC, 15 maio 2020. Disponível em: 〈http://proec.ufabc.edu.br/epufabc/ensino-remoto-na-educacao-basica/>. Acesso em: 17 ago. 2020.

MANZOTTI, Reginaldo. Livro a Nova Batalha. 2021. 


\title{
ABSENTEÍSMO ESCOLAR DE DISCENTE NO ENSINO REMOTO DURANTE A PANDEMIA - COVID19
}

\author{
Sônia Regina Sena de Souza \\ Valdira Almeida Monteiro² \\ Romana Fernandes Ferreira ${ }^{3}$ \\ Luciana Mascena Silva ${ }^{4}$
}

\section{Introdução}

Este artigo visa demonstrar o absenteísmo escolar discente ocorrido no ano de 2020, na EMEF Valdênia Acelino da Silva, município de Maracanaú, o qual acarretou sérios problemas no processo de ensino e aprendizagem dos estudantes. A temática escolhida (Absenteísmo escolar de discente no ensino remoto durante a pandemia - COVID19) versa sobre uma complexa situação que a referida escola enfrentou e enfrenta, após anúncio de suspensão das aulas presenciais em escolas e universidades públicas em todo estado do Ceará, conforme o Decreto n.o 19.586, de 27 de março de 2020, publicado no Diário Oficial do Estado, onde a situação fi-

1 Graduada em Pedagogia e Arte Educadora; Mestra em Ciências da Educação e Inovação Pedagógica; Especialista em: Educação Inclusiva; Psicopedagogia; AEE - Atendimento Educacional Especializado; Psicologia Organizacional e do Trabalho; Gestão Escolar: Administração, Supervisão e/ou coordenação.

E-mail: soniasena68@gmail.com

2 Licenciatura em Formação de Professores do Ensino Fundamental I - Especialista em Administração Escolar;

E-mail: valdiraalmeida0912@gmail.com

3 Licenciatura em Formação de Professores do Ensino Fundamental I - Especialista em: Planejamento Educacional e Gestão Escolar.; E-mail: fromana312@gmail.comciana

4 Graduada em Biologia - UVA; Especialista em Auditoria ambiental - CENTEC; Mestra em Ciências Morfofuncionais - UFC;

E-mail: lumascena2@gmail.com 
cou definida como emergência na saúde pública devido ao Coronavírus.

A partir desse contexto de pandemia, restrição de contato e de ajustamento social e educacional surgiu o Ensino Remoto Emergencial (ERE) como nova modalidade de ensino, trazendo consigo muitos desafios para gestores, docentes, discentes e familiares. O fato é que, frente à impossibilidade de realização das aulas presenciais, observou-se um aumento de absenteísmo escolar dos discentes na dinâmica das aulas, o qual interveio fortemente no processo de ensino e aprendizagem deles. Para tal constatação na veracidade dos fatos, buscou-se identificar os reais motivos que levam ao absenteísmo por parte dos discentes. Para isso, foram consultados documentos da referida escola (Livros de Atas de Atendimento às Famílias), registros de classe e outros documentos, com a finalidade de obter essas informações.

Esta pesquisa tem como propósito demonstrar quais estratégias e intervenções foram tomadas para diminuir o absenteísmo escolar dos discentes na EMEF Valdênia Acelino da Silva, em decorrência da COVID 19. Nossa intenção aqui é apresentar as demandas e as possibilidades viabilizadas pelos docentes e gestores para tornar o ensino remoto atrativo, participativo, e assim diminuir a defasagem no processo de aprendizagem, e consequentemente o absenteísmo escolar dos discentes, em face aos momentos atípicos, vividos por todos que fazem parte da comunidade escolar emoldurados pela pandemia.

Nessa perspectiva, esta pesquisa teve a natureza exploratória, com abordagem qualitativa descrevendo e entendendo as experiências, conhecimentos, relatos e histórias do novo normal na EMEF Valdênia Acelino 
da Silva, a partir de considerações das autoras e de teóricos da educação, tendo como base, as premissas atuais diante da pandemia da COVID 19, que prejudicou o sistema educacional no mundo inteiro.

Segundo André (1986) a pesquisa exploratória revela paisagens que se tecem no cotidiano pedagógico da escola, da sala de aula e das interações entre docentes e discentes, fato que nos ajudam compreender o universo educacional no seu macro e micro contexto social, cultural e histórico, em que esta acontece.

Sendo também bibliográfica, adotando análise de diversas posições sobre o foco da pesquisa, processo fundamental via documentação direta Conforme Fonseca apud Gehardt e Silveira (2009: 37):

A pesquisa bibliográfica é feita a partir do levantamento de referências teóricas já analisadas, e publicadas por meios escritos e eletrônicos, como livros, artigos científicos, páginas de web sites. Qualquer trabalho científico inicia-se com uma pesquisa bibliográfica, que permite ao pesquisador conhecer o que já se estudou sobre o assunto. Existem, porém, pesquisas científicas que se baseiam unicamente na pesquisa bibliográfica, procurando referências teóricas publicadas com o objetivo de recolher informações ou conhecimentos prévios sobre o problema a respeito do qual se procura a resposta (FONSECA, 2002, p. 32).

Nesse sentido, este artigo apresenta uma análise crítica e reflexiva sobre as mudanças atribuídas por essa nova forma de ensinar e aprender, o qual exige enormes desafios por parte de todos, para que o processo de ensino-aprendizagem seja executado por meio do ensino remoto emergencial (ERE), sem causar maiores prejuízos aos discentes. 
O termo Ensino Remoto Emergencial (ERE) é caracterizado por Arruda (2020), como uma necessidade de inter-relação que ele exige entre discentes e docentes, fazendo uso, quase sempre, de plataformas "on-line”, onde ambos estão disponíveis sincronicamente, podendo ser disponibilizado aos discentes, materiais como: vídeos-aulas, entre outros recursos didáticos primordiais para seu aprendizado. Para Behar (2020) o "novo ensino", referindo-se a "remoto", se faz necessário devido à distância geográfica entre docentes e discentes, enquanto o "emergencial", se devem às condições em que foi determinado, mudando toda forma de ensinar e aprender, necessitando replanejar e encontrar novas habilidades e competências.

O Ensino Remoto, não é uma novidade, porém, nesse contexto pandêmico se desenvolveu em nova forma de ensinar e aprender, Litwin (2001, p. 13), definiu como "[...] uma modalidade de ensino com características específicas, isto é, uma maneira particular de criar um espaço para gerar, promover e implementar situações onde os estudantes aprendam". Moran (2015, p. 1) caracteriza o Ensino Remoto como "[...] o processo de ensino-aprendizagem, mediado por tecnologias, onde docentes e discentes estão separados espacial e/ ou temporalmente". Conforme o Art. 10 do Capítulo I do Decreto n.0 5.622 de 19 de dezembro de 2005, assinado pela Presidência da República, o Ensino Remoto caracteriza-se como: [...] modalidade educacional onde a mediação didático-pedagógica nos processos de ensino e aprendizagem se dar pela utilização das Tecnologias da Informação e Comunicação (TIC), com discentes e docentes desenvolvendo atividades educativas em lugares ou tempos diversas (MEC, 2005, p. 1). 
Diante da situação, a EMEF Valdênia Acelino da Silva apoia-se nos seguintes Decretos: municipal n.0 3.942, de 17 de março de 2020, que declarou situação de emergência no Município de Maracanaú; estadual de n.o 19.586, de 27 de março de 2020; e federais conforme portaria do MEC 544 de 2020, que diz sobre "a substituição das aulas presenciais, por aulas em meios digitais, enquanto durar a situação de pandemia do novo Coronavírus - Covid-19 revoga-se ainda as Portarias MEC n.o 343, de 17 de março de 2020, n.o 345 , de 19 de março de 2020, e n.o 473, de 12 de maio de 2020."

Com o olhar investigativo e inserido em fontes primárias e secundárias, pode-se adentrar ao tema com mais rigor, apropriando-se das informações e proporcionando um novo olhar sobre o foco da pesquisa, pelo fato de fazer parte do meio educacional, havendo uma identificação com determinadas situações e cenários apresentados ao longo dela. Desse modo, espera-se descrever a relação do absenteísmo escolar discente com os efeitos da Pandemia, apresentando as intervenções e estratégias que a escola vem desenvolvendo para minimizar as causas e prejuízos no processo de ensino aprendizagem desses estudantes.

Com esse enfoque, neste estudo foram abordados aspectos relacionados ao absenteísmo escolar discente, como conceito, origem, características e fatores causais. Buscou-se ainda, embasamento teórico em autores como: André (1986), Luck (1998), Santos (2002), Paro (2008, 2002 e 1997), Libâneo (2003), Lopes, dentre outros, de relevância para esta pesquisa de natureza bibliográfica.

De acordo com Gesqui (2008, p.40): 
A escola é povoada por diferentes sujeitos com diferentes formações e com diferentes aspirações; a escola tem significados diferentes para alunos, professores, gestores e funcionários; a escola é representada por diferentes representações dos pais, dos moradores do bairro e do comércio onde está inserida.

Assim, para contextualizar essa experiência, torna-se necessário ressaltar que as escolas públicas são de grande importância para a sociedade, as quais assumem um relevante papel enquanto instituição provedora de educação básica sustentadas nos pilares dos conhecimentos: científico, ético e sociocultural, buscando formar crianças, jovens e adultos críticos reflexivos e conhecedores dos seus direitos e deveres.

\section{Absenteísmo Escolar Discente}

O absenteísmo escolar discente pode ser discutido a luz de conceitos, como direitos, deveres, e uma multiplicidade de fatores que intervêm neste processo, exigindo abordagens teóricas diversificadas e análises de perspectiva multidisciplinar com feições diversas, conforme seja o absenteísmo discente na escola pública neste momento de pandemia.

Sendo assim, constatou-se que o absenteísmo escolar discente vem se tornando um problema sério nesse período de pandemia nas escolas públicas, o qual se reflete diretamente no processo de ensino e aprendizagem.

A palavra absenteísmo geralmente designada como falta ao trabalho, está respaldado em Millet e Thin (2012) que utilizam o vocábulo em francês "absenteísmo", derivado do inglês absenteeism, e significa o ato de estar afastado, ausente ou fora, de não comparecer, de 
abster-se. O site, significados.com.br define que "absenteísmo" vem do latim absens que significa estar fora.

Acerca do absenteísmo escolar define-se pela ausência repetida ou prolongada das atividades escolares não justificada pelo aluno, não apenas nas aulas, mas em todas as atividades da escola. A taxa de absenteísmo corresponde à percentagem obtida a partir da relação entre o número de ausências e o número de presenças, num determinado tempo.

Segundo Tavares (2006, pp. 19) Absentismo, palavra utilizada para designar a falta do aluno à escola. Num sentido mais amplo, é a soma dos períodos onde os alunos de uma determinada escola se encontram ausentes, não sendo a ausência motivada por doença prolongada ou licença legal.

Para Reid [...] O absenteísmo escolar discente, [é] entendido como a falta injustificada de comparecimento às aulas por parte de um aluno (REID, 1981). [...] quando estas faltas de assistência se sucedem de forma reiterada ou se prolongam no tempo, o ritmo de aprendizagem do aluno é afetado e, inevitavelmente, começam a surgir problemas de insucesso escolar que, se não forem solucionados rapidamente, podem conduzir a situações de abandono. [...] o absenteísmo escolar discente constitui um dos principais fatores que contribui para o aparecimento de situações de marginalidade, delinquência e analfabetismo. Absenteísmo escolar discente vem sendo destacado em diferentes contextos socioeconômico e cultural, citados por diversos autores a seguir.

Conforme Faro, esses fatores podem ser intrínsecos e extrínsecos os quais levam o estudante ao absenteísmo. Dentre os fatores intrínsecos, são citados a saúde física e o equilíbrio pessoal, o grau de integração 
na escola, as condutas problemáticas e o profundo desinteresse, dentre outros (Ibidem, p. 12). Os extrínsecos, de acordo com Gilly (1986, apud FARO, 2007, p. 12), envolvem:

Variáveis familiares: nível socioeconômico, cultural e acadêmico dos progenitores; qualidade da relação entre os membros da família, valor atribuído à escolaridade e ao trabalho, valores morais, interesse dos pais pela educação dos filhos;

Variáveis atribuíveis à dinâmica da própria escola: sistema organizativo e de coordenação, estilos de ensino dos docentes, clima de convivência, ambiente percepcionado na turma e fora dela;

Variáveis referentes ao currículo: se este se apresenta atrativo na sua formulação, na sua prática, etc.

No âmbito educacional brasileiro, o Ministério da Educação empenha-se a situação de forma aleatória considerando absenteístas, os estudantes com determinado número de falta às aulas registradas pelos diários de classe dos docentes. [...] Devido às dificuldades sistemáticas de mensurar a incidência e manifestações do absenteísmo na escola e suas possíveis correlações com o fracasso escolar, tem-se estabelecido uma tendência preconceituosa em buscar na família, em especial famílias de baixa renda, os verdadeiros culpados por seus maiores níveis de incidência, reproduzindo assim perspectivas simplistas entre pobreza, delinquência juvenil e fracasso escolar (ABRAMOVAY; RUA, 2002, p. 13 - 14).

Referente ao absenteísmo discente escolar, a legislação brasileira determina, que em conformidade com a constituição, em seu artigo 208, parágrafo 3., que "compete ao poder público recensear os educandos no Ensino Fundamental, fazer-lhes a chamada e zelar, 
junto aos pais ou responsáveis, pela frequência à escola” (BRASIL, 1988).

Nesse sentido, buscamos compreender por meio deste estudo quais são as causas que estão ocasionando absenteísmo escolar discente na escola EMEF Valdênia Acelino da Silva, e como ele se manifesta diante da complexidade do processo de ensino e aprendizagem, e da dinâmica escolar, nas quais docentes e discentes estão inseridos.

\section{As Causas Determinantes do Absenteísmo Escolar Discente}

Buscando investigar quais são as principais causas do absenteísmo escolar discente, chegou-se à conclusão de que elas podem ter as mais diversas origens.

Dentre os casos de absenteísmo escolar discente, as causas mais frequentes são:

- desestruturação familiar; progenitores que não dão importância aos estudos;

- ambiente escolar insatisfatório; estudo desinteressante; violência na escola.

- As principais consequências que o absenteísmo escolar pode desencadear, de acordo com pesquisas conduzidas na área, são:

- Insucesso escolar; abandono escolar; analfabetismo; exclusão social; delinquência.

- Observou-se que a maior causa do absenteísmo escolar discente atualmente na escola pública, está relacionada com ao novo modelo da educação com foco no ensino remoto em resposta ao novo cenário mundial desencadeado pela pandemia de Covid-19. 
Com este recorte, apontamos os reais fatores que promoveram e contribuíram para absenteísmo dos estudantes na EMEF Valdênia Acelino da Silva, foram: a falta de acesso às tecnologias, ferramentas digitais e internet; adaptação ao Ensino Remoto Emergencial (ERE) e, outro agravante, muitos estudantes apresentaram sintomas de transtornos ansiosos e depressivos, ocasionado pelo isolamento social e perca de entes queridos, após terem sido contaminados com a COVID-19.

Conforme a CID (Classificação Estatística Internacional de Doenças e Problemas Relacionados com a Saúde) transtorno misto ansioso depressivo é definido "quando o sujeito apresenta em simultâneo sintomas ansiosos e sintomas depressivos, sem predominância nítida de uns ou de outros, e sem que a intensidade de uns ou de outros seja suficiente para justificar um diagnóstico isolado".

Infelizmente fatores como esses acarretam sérios prejuízos não apenas aos discentes, mas também ao corpo docente no desempenho de sua prática pedagógica, a qual necessita manter o elo constante com os discentes para não perder o vínculo, e a afetividade, valores esses que favorecem a credibilidade, confiança e o diálogo, facilitando assim o processo de ensino e aprendizagem. Segundo Lopes, o ser humano aprende muito mais quando há a presença ativa de um mediador. Isto é, quando há uma pessoa que usa de seu conhecimento para intervir (positivamente) na construção do outro. Dessa forma, o mediador serve para dar sentido às experiências, construir um conhecimento conjunto e desenvolver funções cognitivas.

Nesse sentido, Lopes (1996), diz que o docente deve favorecer situações que estimulem a iniciativa e o 
diálogo entre o discente e o docente, bem como o diálogo com o saber acumulado historicamente e situações que despertem o interesse dos discentes na apropriação do conhecimento. E para que essa apropriação do conhecimento aconteça de fato, o docente deve buscar apoio junto aos gestores para sensibilizar os discentes por um diálogo franco e aberto, sobre as causas desse absenteísmo. Ainda apresentar estratégias de ensino que diminuam os prejuízos no processo de ensino aprendizagem.

Dessa forma, percebe-se a importância da compreensão por parte dos docentes e gestores sobre processo pelo qual provém o absenteísmo e, em especial o absenteísmo discente escolar.

Diante do contexto, onde os docentes da EMEF Valdênia Acelino da Silva se encontravam preocupados com o processo de aprendizagem dos estudantes, e o número crescente de absenteísmo durante as aulas remotas, foi realizada uma reunião via Google Meet com o grupo gestor e docentes para buscar soluções diante do exposto. Considerando as diversas causas mencionadas sobre o absenteísmo dos estudantes, na ocasião um grupo de docentes apresentou um Projeto Interdisciplinar denominado "Conhecimento gera Saúde", onde o estudante seja o protagonista do seu conhecimento que tenha a capacidade para realizar um trabalho de busca, união e compartilhamento de saberes, atrelado ao atual contexto pandêmico. Dessa forma, espera-se que o protagonista juvenil possa viabilizar a informação e, consequentemente, conhecimento frente a crise pandêmica que assola o mundo.

De acordo com o Dicionário Interativo da Educação Brasileira - Educa Brasil. (2001) Protagonismo 
Juvenil é a participação do jovem como ator principal em ações que não dizem respeito à sua vida privada, familiar e afetiva, mas a problemas relativos ao bem comum, na escola, na comunidade ou na sociedade. Outro aspecto do protagonismo é a concepção do jovem como fonte de iniciativa, que é ação; como fonte de liberdade, que é opção; e como fonte de compromissos, que é responsabilidade. Dessa forma, o jovem pode atuar na escola, por exemplo, organizando atividades que envolvam alunos e a comunidade, visando a integração de todos. O protagonismo juvenil é importante porque, ao se preocupar com atividades para o bem comum, faz, por exemplo, diminuir o número de faltas às aulas e o envolvimento do jovem com o crime e com a violência.

A expressão protagonismo juvenil vem sendo utilizada na educação há algum tempo. Por isso, a EMEF Valdênia Acelino da Silva, vem desenvolvendo projetos que tornam os estudantes protagonistas do seu processo de aprendizagem.

\section{Comunidade escolar, estratégias e intervenções}

Preocupados com o cenário atual, de tantos desafios e dificuldades no processo educativo, gestores e docentes da EMEF Valdênia Acelino da Silva, se reuniram para apresentar intervenções, e/ou atividades interativas que poderiam ser realizadas no âmbito familiar pelos estudantes, via Web, com o intuito de minimizar as faltas nas aulas remotas e contribuir para o aprendizado deles. Um grupo de docentes propôs o Projeto Interdisciplinar "Conhecimento gera Saúde". Conforme a BNCC (2017) os educadores têm um papel fundamental 
para que o aluno desenvolva a crença no seu potencial e uma visão otimista sobre si, além de propiciar a integração dos alunos e atuação solidária em prol do bem comum.

Nesse sentido o projeto explicitou-se a intencionalidade pedagógica das atividades propostas, voltadas para o progresso no processo de aprendizagem e controle sócio emocional dos estudantes que, prioritariamente aprendem interagindo e vivenciando novos conhecimentos entre discente $\mathrm{x}$ docentes $\mathrm{x}$ discentes em seus diferentes saberes, pois a aprendizagem é produzida independentemente do lugar e do tempo, embora seja a escola o lócus de interação de todos. Essa ação buscou a união e o compartilhamento de saberes atrelados ao contexto pandêmico, de forma que o protagonismo juvenil possa viabilizar a informação e, consequentemente, conhecimento frente à crise sanitária que assola o mundo.

Conforme a concepção de Costa (2006), o Protagonismo Juvenil propõe que os adolescentes sejam os personagens principais (protagonistas) de uma iniciativa prática voltada para a resolução de problemas e conflitos reais na comunidade onde estão inseridos.

Por isso, este o Projeto Interdisciplinar "Conhecimento gera Saúde", teve como metas principais contribuir para o processo de aprendizagem dos estudantes do 6. ao 9.o ano, buscando melhorar a participação ativa em todas as aulas remotas, incentivar trabalho em grupo, mesmo diante de tantos desafios e dificuldades tecnológicas, as quais interferem em demasia na dinâmica das aulas, bem como, no desempenho pedagógico deles. Essas metas aconteceram de forma interdisciplinar, onde os estudantes puderam desenvolver seu 
protagonismo, sistematizando os saberes em ações espontâneas de pesquisa e dados pautados em práticas genuínas dentro e fora da escola.

Pois, a escola é o espaço ideal para propiciar a reflexão ampliada da vida escolar, através de uma prática de aprendizagem criativa, lúdica e significativa. Esse projeto traz uma proposta pedagógica repleta de significado à vida escolar, pois permite que o estudante desenvolva em simultâneo, suas dimensões cognitivas e socioemocionais. Daí a importância de estimular essa prática aos estudantes, a qual irá potencializar sua autodescoberta, desenvolvendo o autoconhecimento e senso de coletividade (além da autonomia), preparando-os para se tornarem protagonistas de sua vida.

Conforme a BNCC (2017) o protagonismo é uma proposta pedagógica que visa desenvolver a autonomia, através da geração de espaços e situações que estimulam a participação criativa, construtiva e solidária na resolução de problemas reais. Onde "Ser protagonista da sua própria história de vida é conseguir construir planos e concentrar esforços para realizá-los.”

Para isso ocorrer o projeto "Conhecimento gera Saúde” propôs os seguintes objetivos:

- Promover a interdisciplinaridade;

- Instigar o protagonismo dos estudantes;

- Produzir e compartilhar conhecimentos situados;

- Agregar práticas multi letradas;

- Efetivar o processo de ensino e aprendizagem pautado em práticas autênticas;

- Aproximar a teoria da prática, dando sentido ao conhecimento construído;

- Incentivar a pesquisa e a produção de dados; 
- Instigar a reciprocidade, a empatia, o espírito de coletividade e aspectos positivos para as relações sociais;

- Intensificar a participação do estudante nas atividades pedagógicas relativas ao atual contexto. Pois, é no exercício do protagonismo que os adolescentes mobilizam valores, competências e instrumental teórico-prático para atuação na sociedade.

O projeto foi aplicado nas turmas do 6.0 ao 9.0 ano por quatro docentes englobando as disciplinas de Ciências, História, Português e Matemática, onde as aulas são ministradas interdisciplinarmente conforme o conteúdo central do projeto: saúde e crise sanitária; foco em gêneros discursivos específicos. Como define a BNCC (2017) "Reconhecendo que a realidade é sincrética e complexa, a interdisciplinaridade permite que possamos combinar a profundidade da especialização de cada área do conhecimento com um olhar atento às conexões, interações e implicações entre os diferentes campos do saber".

Utilizaram-se as TDICs como ferramentas para este fim, pois as tecnologias digitais da informação e comunicação, conhecidas por TDICs, alteram as formas de trabalhar, de se comunicar, de se relacionar e de aprender. Na educação, as TDICs têm sido incorporadas às práticas docentes como meio para promover aprendizagens mais significativas, para apoiar os docentes na implementação de metodologias de ensino ativas, alinhando o processo de ensino-aprendizagem à realidade dos estudantes e despertando maior interesse e engajamento deles em todas as etapas da Educação Básica. 
Nesse sentido, percebe-se a importância do conhecimento sobre utilização das tecnologias metodológicas nas práticas pedagógicas, os quais facilitarão bastante o processo de ensino e aprendizagem, para alcançar os estudantes. Por isto, a (BNCC,2017) enfatiza a importância de "Compreender, utilizar e criar tecnologias digitais de informação e comunicação de forma crítica, significativa, reflexiva e ética nas diversas práticas sociais (incluindo as escolares) para se comunicar, acessar e disseminar informações, produzir conhecimentos, resolver problemas e exercer protagonismo e autoria na vida pessoal e coletiva."

Dessa maneira, as aulas e a produção das atividades durante o desenvolvimento do projeto aconteceram remotamente, via Web (Google Meet, Google Formulários, Canvas, PowerPoint); com discussões baseadas em textos e recursos multimídias, onde aulas aconteceram de forma síncrona e assíncrona. Pois, a Web está mudando a forma de atuar dos docentes e quando aliada à sua prática, torna-se um dispositivo pedagógico. Atualmente, há uma gama de tecnologias auxiliares do ensino remoto, ou seja, as chamadas mídias, e são colaborativas para que haja a interação. Mídias são os meios pelos quais as comunicações e as interações ocorrem, como apostilas digitais, ambientes virtuais e WhatsApp.

Todas essas práticas favoreceram o cumprimento das metas propostas no projeto "Conhecimento gera saúde", as quais favoreceram um processo avaliativo de qualidade e adequado a esses discentes da educação básica participantes. Norteados pelo princípio de que o sujeito aprende na interação com o outro, os mediadores do projeto propuseram como estratégias: que as etapas, objetivos e regras das atividades fossem cumpridas no de- 
correr de três meses (de setembro a novembro) por meio da Gamificação. O termo gamificação se origina da expressão, em inglês, gamification. Em termos gerais significa aplicação de elementos de jogos em atividades de não jogos. Dessa forma, a estratégia propõe o uso de elementos de jogos como: progresso, pontuação, avatares, desafios e rankings em contextos escolares. Sendo assim, a gamificação não precisa da tecnologia para existir.

Segundo Fardo (2013), “a gamificação se apresenta como um fenômeno emergente com muitas potencialidades de aplicação em diversos campos da atividade humana, pois a linguagem e metodologia dos games são bastante populares” (p. 3), entre elas a educação, visto que o uso de atividades gamificadas na educação favorece o engajamento dos estudantes, unindo o útil ao agradável. Levar essa abordagem lúdica para as atividades educacionais pode não apenas motivar os alunos em relação aos assuntos em estudo como também incentivar a permanência nos ambientes educacionais, pois jogos estimulam o esforço em prol de algum objetivo, enquanto proporcionam entretenimento (FARDO, 2013).

A gamificação é um dos métodos usados ao aplicar metodologias ativas de aprendizagem. Diferentemente de uma aula comum, na gamificação, os alunos ganham autonomia e constroem o aprendizado de forma coletiva. Para isso, os mediadores do projeto propuseram as seguintes regras:

- Pontuar, de forma coletiva, as diferentes atividades;

- Para alcançar a pontuação adequada, a turma deve mobilizar o maior número de alunos para participar das atividades; 
- Produzir um infográfico, como produto, a partir de pesquisas de campo (on-line) baseadas no tema geral;

- Será campeã a turma que obtiver o maior número de pontos;

- Se houver empate, os vencedores serão, igualmente, premiados;

A premiação corresponderá a avaliação bimestral em todas as disciplinas, obedecendo a seguinte ordem:

- 1.0 colocado: nota 10,0

- 2.0 colocado: nota 9,0

- 3.0 colocado: nota 8,0.

Dessa forma, o estudante se torna protagonista do seu processo de aprendizagem e o docente atua como um guia para o conhecimento. Portanto, é responsabilidade do estudante se esforçar, pensar e agir para alcançar o êxito.

\section{O processo avaliativo seguiu as seguintes tarefas e pontuação:}

- Frequência nas aulas do Google Meet 40 pontos;

- Maior quantidade de pessoas entrevistadas sobre Covid-19 pelo Google formulários 40 pontos;

- Elaborar um jingle sobre o período da pandemia 20 pontos;

- Produção de um vídeo sobre o atual contexto da pandemia 40 pontos; 
- Elaboração de infográficos 40 pontos;

- Apresentação de seminário para apresentar os dados do infográfico provenientes da entrevista 40 pontos;

- Assiduidade na entrega das atividades das disciplinas 40 pontos;

- Quiz 20 pontos;

- Divulgar o infográfico no Instagram e obter o maior de curtidas 20 ponto;

A partir dessas regras estabelecidas, os docentes responsáveis pelo projeto elaboraram relatórios para registrar e acompanhar cada atividade executada pelos participantes. Vale salientar que por meio dos grupos no WhatsApp, foi possível registrar o controle da frequência e aproveitamento das atividades propostas. Os responsáveis e familiares enviaram registros fotográficos e vídeos, tanto da execução quanto do resultado das atividades desenvolvidas em casa, sendo estas uma forma importante de acompanhamento. No tocante ao registro das atividades planejadas pelos docentes e desenvolvidas pelos estudantes, foi importante arquivá-las em portfólios, virtuais, que servirão de ponte entre o período de aulas remotas e o retorno das atividades presenciais.

Por meio destas estratégias e intervenções, o número de faltas nas aulas remotas diminuiu em até $60 \%$, a participação dos estudantes na escola em busca de atividades impressas aumentou consideravelmente, melhorando o nível de aprendizagem dos discentes participantes do projeto "Conhecimento gera saúde". Demonstrando que a transformação está acontecendo e, de forma positiva, presenteando a esses estudantes 
com uma formação para a vida, construindo, pouco a pouco, um leque de habilidades necessárias ao enfrentamento dos desafios e dificuldades do momento.

A BNCC (2017) ressalta que "Quando falamos em autoria ou em protagonismo juvenil, estamos reconhecendo que os jovens são sujeitos de sua própria aprendizagem e de seu processo de desenvolvimento, e que, portanto, as situações de ensino e aprendizagem devem ser organizadas de modo que eles exerçam, efetivamente, um papel autoral, ativo e criativo de (re)construção e invenção de saberes, que desejamos que eles dominem." Nesse contexto, pode-se afirmar que por meio da execução desse projeto os estudantes receberam novos conhecimentos de forma inovadora, favorecendo a autonomia e compromisso necessário para o cumprimento das tarefas propostas no decorrer do ano letivo de 2020, promovendo a passagem para a série seguinte.

\section{Considerações finais}

Compreende-se que, o absenteísmo escolar discente ocasionado pelo novo cenário de pandemia-COVID19, trouxe sérios problemas em várias esferas educacionais. Por esse motivo, a melhor maneira de combatê-lo é fomentar as relações humanas dentro da escola e/ou fora dela, as quais estão inseridas docentes $\mathrm{x}$ discentes $\mathrm{x}$ família.

Nesse sentido, buscou-se refletir sobre a quantidade de estudantes ausentes durante o ensino remoto, devido aos fatores impactantes relacionados à pandemia no país, bem como os desafios enfrentados por discentes, docentes e familiares. Além, das consequências trazidas pelo contexto atual, como problemas tecnoló- 
gicos, adaptação ao ensino remoto, e situações familiares, os quais acarretaram muitos impactos no processo de ensino e aprendizagem dos estudantes.

Diante do contexto, é compreensível que essas problemáticas do absenteísmo escolar discente, sejam o eixo central na busca de soluções consistentes para evitar danos maiores a formação desses estudantes. Constata-se que a escola é a responsável para encontrar estratégias e intervenções imediatas nesse processo de ensino e aprendizagem, onde todos estão enfrentando os mesmos desafios, evoluindo e aprendendo juntos. É chegado o momento de unir forças, para assegurar que todos ultrapassem esta fase de dificuldades e desafios, mas acreditando que trarão muitos ensinamentos e oportunidades de crescimento a todos que estiverem prontos a ressignificar e repensar as diferentes etapas desse novo contexto educacional.

Percebe-se que a equipe de docentes e gestores obtiveram bons resultados diante das estratégias e intervenções inovadoras desenvolvidas por meio do Projeto "Conhecimento gera saúde", onde as metas e objetivos foram alcançados. Conclui-se que as novas práticas pedagógicas utilizadas pelos docentes promoveram entusiasmo aos discentes que retornarem às aulas remotas, além de favorecer aprendizagem significativas e o protagonismo juvenil.

Torna-se evidente que, para minimizar e até mesmo acabar com o absenteísmo escolar discente, são necessárias a permanência de ações conjuntas que envolvam a gestão $\mathrm{x}$ docentes $\mathrm{x}$ discentes $\mathrm{x}$ família, devendo garantir a todos os recursos necessários para o atingimento dos objetivos propostos de cunho pedagógico, onde a escola continue estimulando os docentes na bus- 
ca incessante de práticas inovadoras, na construção de uma cultura de ensino e aprendizagem com qualidade.

\section{Referências}

ABRAMOVAY, M. A Violência nas Ruas: Absenteísmo e Fracasso Escolar http:// www.miriamabramovay.com/ site/index. php?option=com_content\&view=section\& layout=blog\&id=5\&Itemid=2. Acesso em 21/08/2021

ARRUDA, Eucidio Pimenta. EDUCAÇÃO REMOTA EMERGENCIAL: elementos para políticas públicas na educação brasileira em tempos de Covid-19. Em Rede-Revista de Educação a Distância, v. 7, n. 1, p. 257-275, 2020.

BEHAR, Patricia Alejandra. O ENSINO REMOTO EMERGENCIAL E A EDUCAÇÃO A DISTÂNCIA. Rio Grande do Sul: UFRGS, 2020. Disponível em: https://www.ufrgs. br/coronavirus/base/artigo-o-ensino-remoto-emergencial-e-a-educacao-a-- distancia/.

BRASIL MEC. Decreto № 5.622, De 19 de dezembro de 2005. Presidência da República, 2005. Disponível em: http://portal.mec.gov.br/seed/arquivos/pdf/dec_5622. pdf Acesso em 26 agosto 2021.

BRASIL. MEC. Decreto № 343, de 17 de março de 2020.

BRASIL. MEC. Decreto № 544, de 16 de junho de 2020.

BRASIL. Ministério da Saúde. O QUE É COVID-19?.2020. Disponível em: < https://coronavirus.saude.gov.br/sobre-a-doenca\#o-que-e-covid> Acesso em 02 set 2021.

BRASIL. MEC. Constituição da República Federativa do Brasil - Art. 208 http://portal.mec.gov.br/cne/arquivos/pdf/CEB011_2001.pdf

BRASIL MEC. Decreto № 5.622, De 19 de dezembro de 2005. Presidência da República, 2005. Disponível em: http://portal.mec.gov.br/seed/arquivos/pdf/dec_5622. pdf. Acesso em 26 agosto 2021. 
CID - Classificação Estatística Internacional de Doenças e Problemas Relacionados com a Saúde. https:// www.medicinanet.com.br/cid10.htm - Acesso: 06. de setembro 2021.

COSTA, Antônio Carlos Gomes da. Protagonismo juvenil: adolescência, educação e participação democrática. Salvador, Fundação Odebrecht, 2000.

Decreto no 19.586, de 27 de março de 2020, publicado no Diário Oficial do Estado https://www.ceara.gov.br/ decretos-do-governo-do-ceara-com-acoes-contra-o-coronavirus/. http://basenacionalcomum.mec.gov.br/ implementacao/praticas/caderno-de-praticas/aprofundamentos/193-tecnologias-digitais-da-informacao-e-comunicacao-no-contexto-escolar-possibilidades? Acesso em 06 de setembro de 2021.

Ebook - LIV, Laboratório Inteligência de Vida - Saúde Mental - www.inteligenciadevida.com.br/pt

FARDO. A GAMIFICAÇÃO APLICADA EM AMBIENTES DE APRENDIZAGEM. Marcelo Luís Fardo 2013. RENOTE - Revista Novas Tecnologias na Educação ISSN 1679-1916

FARO, Divisão de Ação Social, Análise da relação entre o perfil psicossocial do aluno e o abandono escolar. Projeto "Integrar para Educar" - Programa Ser Criança. Ministério do Trabalho e Solidariedade Social, da Câmara Municipal de Faro. Portugal, 2007.

FONSECA, J. J. S. Metodologia da pesquisa científica. Fortaleza: UEC, 2002.

GERHARDT, Tatiana E; SILVEIRA, Denise T. Métodos de Pesquisa. Porto Alegre: Editora da UFRGS, 2009.

GESQUI, Luiz Carlos. Organização da escola, absenteísmo docente, discente e rendimento escolar. Dissertação. Mestrado em Educação: História Política, Sociedade. Pontifícia Universidade Católica. São Paulo, 2008, p. 160. 
Instituto de Corresponsabilidade pela Educação. Modelo Pedagógico: Princípios Educativos, Ed. 2. Pernambuco: ICE, 2016, $60 \mathrm{p}$.

LEI COMPLEMENTAR № 101, DE 4 DE MAIO DE 2000. Disponível em: http://www.planalto.gov.br/ccivil_03/ leis/lcp/lcp101. Acessado em: 07 de setembro de 2021.

LITWIN, E. (Org.) Educação a Distância: temas para o debate de uma nova agenda educativa. Tradução Fátima Murad. Porto Alegre: Artmed Editora, 2001.

LOPES, G. T. et al. O adoecer em enfermagem segundo seus profissionais: estudos preliminares. Rev. Enf. UERJ, Rio de Janeiro, v. 4, n. 10, p. 9-18, 1996.

LÜDKE, M; ANDRÉ, M. E. D. A. Pesquisa em Educação: abordagens qualitativas. São Paulo: EPU, 1986.

MACHADO, Ana Maria [et. al.]. 5 Atitudes Pela Educação: Orientações para Coordenadores Pedagógicos. São Paulo: Moderna, 2014, 118 p.

MORAN, José Manuel; VALENTE, José Armando. EDUCAÇÃO A DISTÂNCIA. Summus Editorial, 2015

MORETTO, Vasco Pedro. Prova: Um momento privilegiado de estudo, não um acerto de contas, Ed. 9. Rio de Janeiro: Lamparina, 2016, $186 \mathrm{p}$.

MORIN, Edgar. Os Sete Saberes Necessários à Educação do Futuro, Ed. 2. São Paulo: Cortez Editora, 2011, 102 p.

Nova Escola. Escola é espaço de aprendizagem e protagonismo. Disponível em http://abre.ai/8lb. Acesso em 21 de agosto de 2021.

OMS - ORGANIZAÇÃO MUNDIAL DA SAÚDE. CORONAVIRUS DISEASE (COVID19) SITUATION REPORT. 2020. Disponível em: Acesso em 24 set. 2021.

REID, K. C. Alienation and persistent school absenteism. Research in Education, n. 29, p. 31-40, 1981. Disponível em: Acesso em: 27 agosto de 2021. 
SÁ, Robson Gomes de. A escola e o seu papel na construção do protagonismo juvenil. Revista Científica Multidisciplinar Núcleo do Conhecimento. Ano 04, Ed. 08, Vol. 03, pp. 74-83. agosto de 2019. ISSN: 2448-0959. Link de acesso: 03.09.21 https://www.nucleodoconhecimento.com.br/educacao/protagonismo-juvenil.

SILVA, Zeneide. Todo Educador Deve Saber. Recife: Prazer de Ler, 2017, 112 p.

Tavares, Z. (2006) Absentismo Escolar na Escola Secundária Conego Jacinto da Costa. Praia: ISE. Vasconcelos, M. (2013). Abandono e Absentismo Escolar no concelho de Ponta Delgada. Universidade Fernando Pessoa [Dissertação de Mestrado publicada] 


\title{
TIPOS DE TEMPERAMENTOS PRIMÁRIOS E SEUS REFLEXOS NO ENSINO-APRENDIZAGEM
}

\author{
Daniel Bezerra Bernardino \\ Izabel Cristina de Oliveira Pires² \\ Valéria Alves da Silva ${ }^{3}$ \\ Luciana Mascena da Silva ${ }^{4}$
}

\section{Introdução}

O temperamento do indivíduo a princípio está associado à tendência de estado de espírito, suas reações e ao grau de sensibilidade. Pode ser ainda a combinação de características inatas que se herdam dos pais, influenciando diretamente no comportamento. Já para a psicologia trata-se de um aspecto especial da personalidade, ou seja, as particularidades do indivíduo ligadas ao comportamento. Entende-se que a compreensão do temperamento é essencial para apreensão da personalidade (EVANS, ROTHBART, 2007).

Diante tantos desafios vivenciados pela criança a partir de um ensino-aprendizagem tradicional, a Pedagogia Waldorf, que se baseia na Antroposofia, ensina por meio de uma pedagogia diferente, valorizando espe-

1 Graduado em Pedagogia - FAEPI; Especialista em Gestão Escolar e Coordenação Pedagógica - KURIOS; Diretor Escolar do Município de Maracanaú/CE; E-mail: danielbernardino@yahoo.com.br

2 Graduada em Direito - UNIFOR; Especialista em Docência do Ensino Superior; E-mail: Izabelcristinaoliveira@gmail.com

3 Graduada em Matemática pela UVA; Especialista em Docência do Ensino Superior - KURIOS; Professora da rede estadual do estado do Ceará; Professora da Faculdade Cesma de Maracanaú; E-mail: valstee.alves7@gmail.com

4 Graduada em Biologia - UVA; Especialista em Auditoria ambiental - CENTEC; Mestra em Ciências Morfofuncionais - UFC;

E-mail: lumascena2@gmail.com 
cialmente o sentir, o querer e o pensar - "conhecimento do ser humano - desenvolvida por Rudolf Steiner no início do século XX, não é uma religião; é um caminho de conhecimento" (CASTRO,2010).

O processo de ensino-aprendizagem acontece de várias formas. Sendo assim é transformar o indivíduo e o universo em algo melhor. Dessa forma mediar o processo do conhecimento para que o aluno possa aprender e evoluir cognitivamente, socialmente e culturalmente.

Quando o ser humano realiza a solução de um problema em matemática ou realiza uma avaliação, o mesmo experimenta reações emocionais baseadas acerca das expectativas que apresentaram nas soluções e sobre experiências vividas. Entende-se que as emoções como estadas mentais, positivas ou negativas, conscientes ou inconscientes, têm um impacto relevante nas funções cognitivas e executiva de aprendizagem, podendo ser uma experiência agradável, favorecendo bons resultados, ou ser uma experiência desagradável, traumática.

Assim, essa abordagem é relevante para entendermos a importância sobre os quatros tipos de temperamentos primários, e de que forma os mesmos podem colaborar com uma educação de excelência.

Mediante aos desafios que cercam os profissionais da educação, os temperamentos de acordo com Luria (1990) influenciam no processo de ensino aprendizagem? A partir dessa problemática chegou-se à hipótese de que quando o professor conhece seu aluno por meio do temperamento, buscará o melhor caminho para interagir com seu aluno.

O presente trabalho tem como um de seus intuitos relacionar oportunamente o fator forma de transferir a 
mensagem, e a forma de como bem abordar seu público a depender de seu perfil, afinal, quando sabemos o perfil do nosso interlocutor com certeza podemos nos aperfeiçoar quanto a forma de transferir a mensagem. Assim o objetivo geral que norteou o presente artigo consiste em apresentar por meio da revisão literária a concepção da influência da teoria dos quatros tipos de temperamentos primários no ensino-aprendizagem refletindo sobre a Pedagogia Waldorf, bem como à ligação do mesmo com as inteligências múltiplas.

Nesse contexto, ao ler sobre temperamentos, quando hoje a filosofia e a doutrina nos trazem quatro formatos, quais sejam: o colérico, o sanguíneo, o fleumático e o melancólico, podem aprender com isso, oportunamente, a não só compreender mais do outro, mas, sobretudo mais de si, o que nos proporciona um amadurecimento profissional, pessoal e emocional.

O material utilizado para análise do trabalho compreende a pesquisa de cunho exploratório, que a partir de um levantamento bibliográfico, proporciona maiores informações acerca da problemática levantada, com a finalidade de construir hipóteses, e assim colaborar com a compreensão da temática apresentada.

Neste texto você descobrirá o que é o temperamento, a definição de temperamento de acordo com uma das linhas da psicologia, e os tipos de temperamento que existem além, é claro, de como é que cada um dos tipos de temperamento são.

\section{História de temperamentos}

A teoria Humoral foi desenvolvida na Grécia antiga por Hipócrates(460 a.c-357a.c), "pai da medicina", 
baseado na teoria de Empédocles (terra, ar, fogo e água) que relaciona os temperamentos de acordo com o estudo do corpo humano, nos quais representavam quadros humores corporais (sangue, fleuma, bile branca e bile negra), ficando organizado da seguinte forma: o estado calórico (tipo sanguíneo); o estado seco (tipo colérico); o estado frígido tipo melancólico); e por fim o estado húmido (tipo fleumático).

Mais tarde, Cláudio Galeno (considerado o mais talentoso médico investigativo do período romano) usou esta teoria para desenvolver os quatro temperamentos primários e secundários relacionados à dominância de uma das quatro qualidades descritas por Hipócrates. Atualmente essa tipologia é conhecida por teóricos e leigos de todo o mundo. De acordo o mesmo Caron (2001), "o Galeno - 200 a.C. foi o primeiro a nomear os quatro temperamentos: sanguíneo, colérico, melancólico, fleumático, e a aperfeiçoar o pensamento de Hipócrates" (p. 57).

\section{Temperamento}

Temperamentos são um conjunto de características que, aliadas a fatores externos (experiências vividas, ambiente, cultura, educação, etc.) definem nossa personalidade e comportamento. Naturalmente todos os temperamentos possuem pontos fortes e fracos. Sobre temperamento, Allport (1937) citado por Mesquita (2014, p.4), diz:

Segundo Strehlau (2002), Allport foi o teórico que contribuiu da melhor forma para a compreensão deste conceito, pelo menos nos países ocidentais. Allport (1937, citado por Strelau, 2002, p. 29), dá relevância às emoções e define o tempe- 
ramento da seguinte forma: "O temperamento refere-se aos fenómenos característicos da natureza emocional de um indivíduo, incluindo a sua suscetibilidade à estimulação emocional, a sua habitual força e velocidade de resposta, a qualidade do seu humor dominante e todas as particularidades de flutuação e intensidade do humor, estando esses fenômenos dependentes de uma base constitucional, e logo, largamente hereditários na sua origem".

Na perspectiva do autor supracitado, compreende-se que temperamento está intrinsecamente ligado à personalidade, porém observa-se diferentes discussões sobre o mesmo. Não obstante é notório que existem pontos de concordância entre os teóricos, por exemplo, acerca da base biológica do temperamento.

É importante ressaltar que existe diferença entre os conceitos de personalidade, temperamento e caráter, porém os mesmos estão interligados. Tanto o caráter quanto o temperamento são conjuntos de características das pessoas que definem a personalidade. A principal diferença entre temperamento e caráter é a origem, enquanto o temperamento é biológico e inato, o caráter é apreendido (MCADAMS; PALS, 2006).

Nesse sentido, quando pretendemos descrever uma pessoa exaustivamente, costumamos detalhar os aspectos que definem o caráter dessa pessoa, uma vez que o caráter é o que as pessoas mostram em nível social. A segunda diferença entre temperamento e caráter, deriva da primeira diferença, e é sua possibilidade de modificação.

O temperamento, sendo biológico, é mais estável e permanece o mesmo, enquanto o caráter, sendo aprendido, pode ser modificado através da aprendizagem 
(MESQUITA, 2014). Em suma, assimila-se, temperamento e caráter são dois conceitos facilmente confundidos pela relação que ocorre entre eles, já que ambos fazem parte da personalidade.

\section{Tipos de temperamento}

Os estudos científicos confirmam a existência de quatro tipos de temperamentos: sanguíneo, colérico, melancólico e fleumático. O tipo sanguíneo caracteriza o homem com alegre, comunicativo e despreocupado. Sente emoções momentâneas de forma intensa, reage rápido às situações e não costuma guardar rancores. Assim prevalece o terceiro membro da entidade humana que reflete tudo que é prazer, sofrimento, alegria e dor. Para Antroposofia é um corpo real dos impulsos e desejos (STEINER, 1919 traduzido por MONGES, 2005).

Pessoas com um temperamento sanguíneo são emocionalmente instáveis, egoístas, egocêntricas, indisciplinadas, com pouca força de vontade, eles querem ser o centro das atenções e fazer o melhor para isso, são inquietos, despreocupados, desorganizados e, apesar de extrovertidos, são pessoas inseguras.

O Tipo colérico mandão, impetuoso e líder. Sente emoções de forma intensa, reage rápido às situações e costuma guardar rancores. Nesse temperamento a força da pulsação do sangue é o que predomina, fortalecendo o seu "eu", gerando um centro forte e firme no interior do homem. O temperamento colérico favorece o quarto membro da entidade, que é o eu. Nesse sentido o seu "eu" é o precursor do atuar e querer direcionado ao exterior. Com isso o colérico mostra-se um homem 
que em todas as circunstâncias quer impor a sua vontade (STEINER, 1919 traduzido por MONGES, 2005).

Este tipo de temperamento, ou seja, o temperamento colérico se refere àqueles que provarem para ser rápido, muito ativo, arrojado, excitável, rápido - temperado, a prática na tomada de decisões, autossuficiente, independente, extrovertida (mas não tanto quanto as pessoas sangue), metas e objetivos conjunto são ambiciosos, intuitivo, quente, voluntarioso, determinado, firme, impondo, dominantes, manipuladoras, criativas opiniões de pessoas (tem muitas ideias, planos, metas, objetivos ...) consideram-se muito capaz de alcançar o que eles propõem, entre outros.

O tipo melancólico é pensador, criativo e pessimista. Sente emoções de forma intensa, é lento para reagir às situações e costuma remoer mágoas temperamento melancólico é caracterizado por um fraco sistema nervoso, fato que faz com que as pessoas com elevada prevalência neste tipo de temperamento possuam uma alta sensibilidade, um elevado nível de atividade, concentração e atenção, e um baixo grau de flexibilidade do corpo as mudanças.

Em adição, às pessoas com um temperamento melancólico são caracterizados como introvertido, pouco expressivo, perfeccionistas, pessimista, inveja, ansiedade, antissocial, desconfiado, excessivamente sensível emocionalmente, propenso ao sofrimento, seu humor é geralmente uma tristeza profunda e estável tempo, eles tendem a dar muita importância a tudo, criando preocupações e dificuldades desnecessárias, etc.

Nesse temperamento o que se sobressai é o corpo físico se expressando a partir dos órgãos sensoriais. $O$ homem melancólico não consegue dominar seu corpo, 
tem dificuldades de se sustentar em sua própria estrutura corporal, apesar do andar firme, ao mesmo tempo é pausado, arrastado, mostrando que o homem que tem como característica o seu interior, não tendo poder sobre seu corpo físico, assim sente sofrimento e dor (STEINER, 1919 traduzido por MONGES, 2005).

O tipo fleumático é controlado, equilibrado e passivo. Sente emoções de forma fraca, é lento para reagir às situações e não guarda rancores. Entende-se por temperamento fleumático aquele que se baseia em um sistema nervoso lento e equilibrado, que caracteriza as pessoas pelo facto de ter uma baixa sensibilidade, elevada atividade, concentração e atenção, com baixa flexibilidade para mudar.

Nesse temperamento o corpo sublime do homem é que prevalece. O primeiro membro muito sensível da sua natureza humana que prevalece, onde os membros são tão reais e primordiais quanto o corpo físico. O coração físico está por baixo de um coração elétrico, assim como o cérebro físico está por baixo de um 'cérebro elétrico"' (STEINER, 1919 traduzido por MONGES, 2005).

Finalmente, o temperamento fleumático é distinto dos outros três, particularmente devido à sua tendência para se concentrar em sua vida interior e tentar não entrar ou se envolver em atividades e vida pessoal dos outros, demonstrando carinho sem demonstrá-lo.

\section{Os reflexos dos temperamentos primários no ensino-aprendizagem}

Diante do exposto compreende-se que os temperamentos possuem características distintas, das quais refletem habilidades individuais, havendo relação dire- 
ta com o ensino-aprendizagem, visto que cada indivíduo possui uma forma diferente de aprender. Desta forma, de acordo com Gardner (1994, traduzido por VERONE$\mathrm{SE}, 1995)$, as pessoas possuem habilidades diversas, e dessa forma se valem para criar algo, para resolver problemas e produzir bens sociais e culturais, dentro do contexto. Então fica claro que existe uma inteligência uniforme, padronizada para cada ser humano, mais que há vários tipos de habilidades.

O processo ensino-aprendizagem parte do pressuposto do conceito de Pedagogia, conduzir a criança, a arte de ensinar. É importante entendermos que o ensino-aprendizagem não acontece de forma dissociada, ou seja, não existe ensino sem aprendizagem, e que as relações estabelecidas por meio do ensino-aprendizagem ocorrem de várias maneiras: educador e educando, trocam de papéis o tempo inteiro, crianças e adolescentes têm muito o aprender entre si, assim como, todos o que fazem parte do universo escolar, constrói saberes o tempo inteiro. Dessa forma, educação é um processo permanente do homem, em qualquer período de sua vida cultural e social, valorizando vivências, histórias e individualidade de cada um que circula pelos ambientes escolares.

Sobre ensino-aprendizagem Paulo Freire (1996, p. 13), afirma:

Ensinar inexiste sem aprender e vice-versa e foi aprendendo socialmente que, historicamente, mulheres e homens descobriram que era possível ensinar. Foi assim, socialmente aprendendo, que ao longo dos tempos mulheres e homens perceberam que era possível - depois, preciso - trabalhar maneiras, caminhos, métodos de ensinar. Aprender precedeu ensinar ou, em outras pala- 
vras, ensinar se diluía na experiência realmente fundante de aprender. Não temo dizer que inexiste validade no ensino de que não resulta um aprendizado em que o aprendiz não se tornou capaz de recriar ou de refazer o ensinado, em que o ensinado que não foi apreendido não pode ser realmente aprendido pelo aprendiz.

Para atingirmos uma educação de excelência, é imprescindível que o professor seja consciente do seu papel, pois o indivíduo, influencia no universo, não apenas pelo que faz, mas por tudo que o mesmo representa como ser, ou seja, por tudo que ele "é". Para tanto o professor por meio da autoeducação, procure estabelecer uma relação espiritual com seus alunos, procurando diminuir a heterogeneidade existente entre os alunos de uma sala de aula, aos tipos fundamentais de temperamento - sanguíneo, colérico, melancólico e fleumático. Cogita-se ainda, que o educador nos primeiros dias de aula, identifique seus alunos de acordo com o temperamento para que, para que, assim possa organizar grupos de quatros alunos contemplando os quatro tipos de temperamentos, para que os mesmos possam realizar atividades, e dessa forma os grupos se complementariam, compartilham interesses e consequentemente aprenderiam uns com os outros, respeitando a individualidade de cada um (MUTARELLI, 2006).

De acordo com a literatura fica cada vez mais evidente a importância da afetividade no processo de aprendizagem, despertando no indivíduo a confiança, a realizar atividades desafiadoras, e pôr fim à vontade de aprender. "Pedagogia Waldorf, que apresenta outra realidade, uma realidade baseada no amor, no afeto e no diálogo. Tem vida, poesia e esperança” (CASTRO, 2010). 
Então, o presente estudo pode sim ajudar muitos a compreenderem que seu modus operandi deve ser elaborado a partir do conhecimento em face do seu temperamento e do temperamento do outro, favorecendo um aprendizado humanizado e com foco na aprendizagem.

\section{Considerações finais}

É consenso que o fracasso escolar não é só do aluno e/ou do professor, mas de um conjunto de fatores que interferem na escola em seu dia-a-dia, os quais influenciam o processo ensino-aprendizagem e contribuem com o sucesso ou fracasso escolar. Estrutura física, métodos de ensino, gestão da escola, graus de dificuldades de conhecimento prévio dos alunos e desigualdades socioeconômicas são sempre os principais fatores apontados nesta influência, seja de forma positiva ou negativa.

Por outro lado, no presente artigo tivemos a pretensão de destacar que a construção do conhecimento ocorre a partir de um intenso processo de interação entre as pessoas e que o conhecimento acerca dos temperamentos irá auxiliar o professor na condução dessas interações de suas aulas em todas as disciplinas.

Neste sentido, é fundamental que o educador se desvincule um pouco das regras curriculares e perceba que a influência da teoria dos 04 temperamentos é altamente positiva para o sucesso escolar, pois chama a atenção para o fato de que preocupar-se com o desenvolvimento da capacidade de se relacionar bem com os outros e consigo mesmo, evita transtornos que repercutem no processo ensino-aprendizagem.

Assim, o presente trabalho cumpre o seu objetivo de abordar os fatores emocionais que podem influen- 
ciar o aprendizado dos estudantes, trazendo algumas possibilidades de soluções para os impasses potenciais encontrados em ambientes de aprendizagem.

Por fim, os autores propõem o aprofundamento de trabalhos futuros relacionados a essa temática e as relações existentes entre sentimentos e emoções nas relações escolares para possíveis mediações de conflitos no ambiente escolar.

\section{Referências}

CARON, G. Acompanhar a criança segundo o seu temperamento, na escola e em casa. [S.l.]: Les Éditions de Mortagne, 2001.

CASTRO, M. J. M. G. Pedagogia Waldorf: uma educação baseada no diálogo, afeto e arte. 2010. 84 f. Dissertação (Mestrado em Educação). Centro Universitáario Salesiano de São Paulo, São Paulo, 2010.

EVANS, D.; ROTHBART, M. (2007). Developing a model for adult temperament. Journal of Research in Personality, [S.1.], v. 41, p. 868-888, 2007.

FREIRE, P. Pedagogia da autonomia: saberes necessários à prática educativa. 25. ed. São Paulo: Paz e Terra, 1996.

GARDNER, Howard. Inteligências múltiplas: A teoria na prática. Tradução de Adriana Veríssimo Veronese. Porto Alegre: Artes Médicas, 1995.

LURIA, A. R. Desenvolvimento cognitivo: Seus fundamentos culturais e sociais. Tradução de Fernando Limongeli Gurgueira. São Paulo: Ícone, 1990.

MCADAMS, P.; PALS, L. A new big five: fundamental principles for an integrative science of personality. American Psychologist, [S.1] v. 61, 204-217, 2006. 
MESQUITA, A. G. Desenvolvimento da versão portuguesa do questionário de temperamento do adulto: relações com a personalidade, a psicopatologia, a religiosidade e a espiritualidade. 2014. 87 f. Dissertação (Mestrado Integrado em Psicologia) Núcleo de Pesquisa Cognitiva Comportamental e Integrativa, Universidade de Lisboa, Lisboa, 2014.

MUTARELLI, S. R. K. Os quatros temperamentos na antropofasia de Rudolf Steiner. 2006. 152 f. Dissertação (Mestrado) Pontifícia Universidade Católica de São Paulo - PUC-SP, São Paulo, 2006.

SMOLE, K. C. S. Múltiplas inteligências na prática escolar. Brasília: Ministério da Educação/Secretaria de Educação a Distância,1999, 80p.

STEINER, R. Arte da educação I: o estudo geral do homem, uma base para a pedagogia. Tradução de Rudolf Lanz, Jacira Cardoso. São Paulo: Editora Antroposófica, 1988. 


\title{
A AFETIVIDADE E A INTELIGÊNCIA EMOCIONAL COMO ELEMENTOS DE UMA GESTÃO EDUCACIONAL HUMANIZADA COM VISTAS À APRENDIZAGEM SIGNIFICATIVA
}

\author{
Yana Mara Lessa Bernardo ${ }^{1}$ \\ Maria Marylene Ferreira Farias ${ }^{2}$ \\ George Lopes Valentim ${ }^{3}$ \\ Luciana Mascena Silva ${ }^{4}$ \\ Rita Cristiane de Oliveira Gomes ${ }^{5}$
}

\section{Introdução}

Psicologia Organizacional e do Trabalho, segundo Bertoldi (2013, p. 19), se ocupa das pessoas em seu trabalho, objetivando contribuir com as organizações no alcance máximo de seus recursos humanos, igualmen-

1 Graduada em Pedagogia - UVA; Especialista em Gestão Escolar UFC; Especialista em Gestão Publica Municipal - UECE; Especialista em Docência do Ensino Superior - FACESMA; Professora do município de Maranguape-CE Técnica da SEDUC de Maracanaú-CE; E-mail: yanamara3@gmail.com

2 Graduado em Direito - UNIFOR; Administração - UFC; Especialista em Direito e Processos Administrativos - Unifor; Servidor Público do município de Maranguape; Secretário de Educação do município de Maracanaú/CE E-mail: georgelopesvalentim@hotmail.com

3 Graduada em Administração - UFC; Coordenadora de Planejamento do município de Educação de Maracanaú;

E-mail: meyrefarias20@gmail.com

4 Graduada em Biologia - UVA; Especialista em Auditoria ambiental - CENTEC; Mestra em Ciências Morfofuncionais - UFC;

E-mail: lumascena2@gmail.com

5 Especialista em Docência do Ensino Superior - Facesma; Gestão Escolar e Coordenação Pedagógica - Falc; Psicopedagogia Clínica, institucional e hospitalar - CETREDE; Gestão e Políticas Públicas - Fak. Graduada em Licenciatura Pedagogia - UVA; Professora da rede municipal de Maracanau há 33 anos e de Fortaleza há 20 anos; Atualmente Diretora Acadêmica da Faculdade Cesma de Maracanaú- FACESMA; E-mail: cristiane@facesma.com.br 
te cuidando do bem-estar e saúde mental desses. Nesse sentido, as emoções e os afetos tem significativa atribuição na vida das pessoas ao auxiliar ou complexificar a evolução do clima de bem-estar no trabalho e, por consequência, agir na saúde do trabalhador e de sua instituição. De forma que, as expressões de afeto gentis no trabalho, a probabilidade de agregar a emoção e a razão para apreender a complexidade do comportamento institucional e o efeito das condições ambientais de trabalho nas emoções e o humor do trabalhador podem fazer a diferença no processo de aprendizagem.

Com fundamento em estudos realizados por Correia e Mata (2020, p. 4) é imensa "a quantidade de situações em que a Inteligência Emocional (IE) pode ser aplicada no local de trabalho das organizações". Ainda consoante Correia e Mata (2020, p. 4) são habilidades decorrentes da aplicabilidade da IE na vida das pessoas: o desenvolvimento da capacidade necessária para manter um bom relacionamento com os colegas; habilidade para solucionar um problema complicado; habilidade para realizar uma tarefa de maior complexidade [...].

Outros sim, as emoções exercem uma função notável no ambiente de trabalho, visto que é um espaço em que a pessoa está continuamente sujeita à encontrar episódios imprevisíveis, tendo que lidar com emoções de forma ágil, aplicando-as de forma a conduzir a atitude e raciocínio com o propósito de obter mais acertados resultados e resolver desafios e conflitos.

Nessa direção, o presente artigo tem por objetivo compreender até que ponto o trabalho técnico tem contribuído, para o bem-estar, a satisfação, o apropriado desenvolvimento intelectual e compromisso com todos os envolvidos no processo educacional, investigando 
possibilidades de uma gestão democrática em prol de uma educação humanizada.

Metodologicamente optou-se pela pesquisa bibliográfica e documental com uma abordagem qualitativa. Por fim, esse texto foi organizado em cinco seções. A primeira traz a parte introdutória, contexto, relevância, seu objetivo, metodologia e estrutura. A segunda discute a relação afetividade $\mathrm{x}$ aprendizagem. Na terceira, de forma breve e resumida, se dialoga sobre autoestima na educação e aprendizagem. A quarta descreve a relação da afetividade vista por alguns autores. E na quinta e última seção, são elencadas as conclusões.

\title{
A relação Afetividade x Aprendizagem
}

O conceito de afetividade em conformidade com Salla (2011) está relacionado:

\begin{abstract}
[...] à capacidade do ser humano de ser afetado positiva ou negativamente tanto por sensações internas como externas. A Afetividade é um dos conjuntos funcionais da pessoa e atua, juntamente com a cognição e o ato motor, no processo de desenvolvimento e construção do conhecimento (SALLA, 2011, p. 1).
\end{abstract}

Destarte, trabalhar com educação exige muitas habilidades e muita disposição por parte dos profissionais. Visto que, afetividade é uma questão essencial para uma educação de qualidade, pois permite uma relação mais sólida, entre técnicos, gestores, docentes e discentes o que possibilita um maior desenvolvimento e aprendizagem dos discentes.

A Psicologia define a Inteligência Emocional como o poder de identificar as suas emoções e as alheias, assim no contexto ensino-aprendizagem, adultos que 
quando criança apresentavam dificuldades emocionais, poderá sofrer consequências que dificultaram o desempenho de suas atividades caso não consiga desenvolver gatilhos, habilidades comportamentais.

A interação social que se estabelece no ambiente de trabalho contribui para o desenvolvimento cognitivo do indivíduo, porquanto este é constantemente confrontado com diferentes pontos e influenciado pela escala de valores que o grupo adota. Destas interações sociais se determinará o papel que cada um desempenha socialmente.

Nesse sentido, faz-se necessário analisar quais tipos de conflitos afetivos podem ser desencadeados nestas relações e quais as consequências para o desenvolvimento da aprendizagem no final do processo. Em um período de pandemia sentimentos como a insegurança se aflora, deixando mais evidentes os aspectos técnicos e nessa relação se destaca no trabalho quem traz na vida pessoal mais equilíbrio.

É basilar fazer esta análise para que o processo de ensino e aprendizagem não seja prejudicado no decorrer do tempo. Por isso consideramos importante que os profissionais trabalhem o autoconhecimento, conhecer minimamente sobre habilidades que permitam o gerenciamento de seus sentimentos e a forma como darão respostas baseada nesta inteligência, ampliando a relação afetiva com os companheiros de trabalho, instigá-lo, incentivá-lo e estimulá-lo de modo que ele se sinta capaz de aprender e ensinar. O reflexo do bom trabalho de uma equipe técnica reflete no chão da escola.

Nessa perspectiva Tassoni (2000) esclarece:

Toda aprendizagem está impregnada de afetividade, já que ocorre a partir das interações so- 
ciais, num processo vincular. Pensando, especificamente, na aprendizagem escolar, a trama que se tece entre alunos, professores, conteúdo escolar, livros, escrita etc., não acontece puramente no campo cognitivo. Existe uma base afetiva permeando essas relações (TASSONI, 2000, p. 71).

As experiências vividas ocorrem, inicialmente, entre os indivíduos envolvidos, no plano externo (interpessoal). Por intermédio da mediação, elas vão se internalizando (intrapessoal), ganham autonomia e passam a fazer parte da história individual. Essas experiências também são afetivas. Os indivíduos internalizam as experiências afetivas com relação a um objeto específico e isso faz com que eles possam aprender de forma mais eficaz, refletindo nas tomadas de decisão. Embora adultos, alguns indivíduos relembram e repetem posturas de quando era criança, de quando ainda estava na educação básica, de início de carreira.

Elias Leite cita que "muito mais importante do que a quantidade de conhecimento e informação que possamos ter é a capacidade de acessá-los" (2017, p. 73) pessoas amadurecidas emocionalmente, independente do nível de formação, conseguem mais tranquilamente buscar resolutividade, ponderar e avaliar os problemas. Destacam-se nas equipes como bons conselheiros.

Então, a boa relação de líder com seus colaboradores é fator fundamental para o processo de aprendizagem, pois em forma de cascata esses sentimentos são transmitidos até alcançar aos discentes. Posto que, todos eles (desde o líder até quem está na ponta) necessitam de uma atenção dobrada ouvindo e orientando sobre as motivações e os medos, acessando o conhecimento que há em cada um, pois a aprendizagem se dá 
em um ritmo muito próprio, o qual precisa ser levado em consideração. Assim sendo, será garantida uma aprendizagem significativa e tal processo se dará de forma mais saudável, evidenciando um processo com responsabilidade e compromisso.

O aluno sente que seus professores constituem equipe com uma finalidade e que está se valoriza pela intensidade com que se respeita, respeita sua individualidade e a inteligência e age com espontaneidade afetiva (ANTUNES 2006, apud TAIAR, 2009, p. 83).

É necessário relatar a importância que tem o bom relacionamento entre secretaria e escola. Esta relação quando é realmente satisfatória possibilita um maior interesse e, consequentemente, sucesso nos encaminhamentos. Gestores que tratam mal os seus docentes, provavelmente não terão um desempenho positivo no trabalho e com certeza dificulta a possibilidade de ampliação do conhecimento dos discentes. Técnico que não possui um bom diálogo com o núcleo gestor, perde de vista as ações da escola, as demandas fogem do controle. Técnicos, docentes e discentes requerem uma relação afetiva sólida, o que não significa dizer que a secretaria não poderá agir com autoridade, mas o que não pode é atuar com autoritarismo, descartando toda a possibilidade de um vínculo mais afetivo entre os setores e as escolas.

Ao se pensar na relação secretária e escola numa perspectiva dialética, não se pode pensar nos sujeitos dessa relação de forma bipolar e nem em um desenvolvimento que ocorra de maneira linear, mas, numa relação dinâmica, que proporciona transformações nas pessoas envolvidas, de maneira evolutiva, de forma 
a obter acréscimo de experiências e conhecimentos o que causa modificações nos sujeitos da ação e no próprio processo de aprendizagem. Assim, enquanto os indivíduos envolvidos produzem e usufruem o conhecimento, também se tornam produto do mesmo, da mesma forma que interagem entre si, ensinando e aprendendo, independente do papel ocupado por cada um, seja o de técnico, de gestor, de docente ou de discente.

Sempre que as pessoas se reúnem para chegarem a um consenso, seja numa reunião de planejamento executivo ou como uma equipe trabalhando para chegar a um produto partilhado, têm num sentido muito concreto um QI de grupo, que é a soma total dos talentos e aptidões de todos os envolvidos. A forma como realizarão a sua tarefa bem como o êxito que obterão, serão determinados pelo nível desse QI. O tipo de elemento mais importante na inteligência de grupo, revela-se, não é o QI médio no sentido acadêmico, mas sim a inteligência emocional. A chave para um alto QI de grupo é a harmonia existente entre os membros que o compõem. É essa capacidade de harmonizar que, mantida a igualdade de condições em tudo mais, tornará um grupo especialmente talentoso, produtivo e bem-sucedido, e fará outro - com membros cujo talento e habilidade são iguais em outros aspectos - se sair mal (GOLEMAN, 2011, p. 203).

Por esse ângulo é significativo, valorizar as interações sociais. Algo que ficou bastante restrito, devido às orientações sanitárias, o trabalho remoto e mesmo presencial em formato de rodízio (escala para diminuição do quantitativo de pessoas no mesmo ambiente). A interação entre as pessoas além de permitir a soma total dos talentos e aptidões de todos os envolvidos, proporciona uma aprendizagem e um melhor entendimen- 
to das situações que são colocadas nas relações interpessoais.

Vygotsky (1994, apud TASSONI, 2000, p. 77), ao destacar a importância das interações sociais, traz a ideia da mediação e da internalização como aspectos fundamentais para a aprendizagem, defendendo que a construção do conhecimento ocorre a partir de um intenso processo de interação entre as pessoas. Portanto, é a partir de sua inserção na sociedade que a criança, através da interação social com as pessoas que a rodeiam, vai se desenvolvendo.

A capacidade de pôr de lado nosso foco e impulsos autocêntricos tem vantagens sociais: abre o caminho para a empatia, para ouvir de fato, para adotar a perspectiva de outra pessoa. A empatia, como vimos, leva ao envolvimento, ao altruísmo e à piedade. Ver as coisas da perspectiva dos outros quebra estereótipos tendenciosos e, assim, gera a tolerância e a aceitação das diferenças. Essas aptidões são cada vez mais exigidas numa sociedade cada vez mais pluralística, permitindo que as pessoas convivam em respeito mútuo e criando a possibilidade do discurso público produtivo. São artes básicas da democracia (GOLEMAN, 2011, p. 337).

Nesse ponto de vista, a relação que a pessoa estabelece no ambiente em que vive é determinante no processo de construção do seu próprio conhecimento. É ver as coisas da perspectiva dos outros, aceitando as diferenças e respeitando-se mutuamente. Por isso, a convivência é muito importante no processo ensino-aprendizagem, dado que a afetividade estará mais ou menos aguçada a partir do relacionamento entre as pessoas. Dependendo de como ela estará, poderá contribuir positiva ou negativamente. 


\section{Autoestima na educação e aprendizagem}

Para aprender algo na vida precisa-se de interesse, vontade própria e motivação. Só se aprende aquilo que chama atenção e desperta curiosidade. Mas para que a aprendizagem se efetive faz-se necessário que a pessoa esteja com a autoestima elevada e motivada a receber novas informações. Em época onde as mortes (pandemia) fazem parte da grade principal da maioria dos telejornais fica difícil encontrar nas pessoas a motivação de forma latente.

O desafio se torna maior quando técnicos da educação precisam fazer direcionamentos sobre algo que é desconhecido até para eles, mais uma vez evidenciando a necessidade em saber lidar com as emoções, essa ação é mais valorosa que a competência de processar informações. Saber trabalhar as emoções colabora na tomada de decisões.

Aprender por que alguém quer que a gente aprenda ou simplesmente por que alguém diz ser importante aprender, muitas vezes não desperta curiosidade, vontade ou motivação para desenvolver-se intelectualmente. A aprendizagem precisa de um sentido e um significado real para os que buscam ampliar seus conhecimentos em qualquer situação.

As experiências cotidianas exercem influências consideráveis na autoestima. Situações de perda, frustrações, o não reconhecimento pelo que se faz, pelo que se é, críticas negativas, comentários depreciativos, entre outros fatores, contribuem para a baixa autoestima, gerando insegurança, dúvidas, negativismo, inibindo a relação positiva com o meio e o prazer de extrair o melhor da vida (SPAGOLLA, 2009, p. 13). 
Nessa perspectiva, no processo educacional, elevar a autoestima dos envolvidos (profissionais e discentes) é imprescindível. A motivação e o despertar para novas descobertas se dão pela capacidade que se tem e muitas vezes não se percebe.

Uma convivência saudável traz diversos benefícios, a importância do reconhecimento, fortalecer o trabalho do outro, regar a esperança a vontade de lutar e conquistar os sonhos, compreendendo que fazer bem ao próximo reflete diretamente no seu dia a dia. Possibilitar diferentes tempos para aprender, considerando o ritmo de cada um e o exercício da persistência necessária e algumas aprendizagens. Propiciando momentos em que possam mostram os seus talentos, sendo desafiados e estimulados, sentindo livre para expressar-se.

A importância da relação do bem-estar com a aprendizagem, pode ser confirmada até na postura, observando aspectos da autoestima, de maneira histórica e conceitual, relacionando os profissionais individualmente e toda sua história familiar.

Paulo Vieira afirma que "Se você quer influenciar e conduzir pessoas a grandes desafios, seja capaz primeiro de influenciar sua própria fisiologia, de mudar a você mesma, tornando-se parecida com suas palavras e objetivos. Aí sim todos, e principalmente você, crerá em suas palavras e seus propósitos, todos seguirão suas ideias" (2017, p. 92). A forma como os comandos são dados, a postura do líder, tudo influencia no resultado final da ação.

É possível compreender que a autoestima é um fator muito relevante para a saúde psicológica do ser humano, pois ela se conceitua em o indivíduo saber gostar e valorizar a si mesmo, para que possa enaltecer 
os demais aspectos da vida, o mundo em geral. Dessa maneira, a abordagem de trabalho na educação, como fator que potencializa o favorecimento da autoestima dos profissionais envolvidos, independente da função que exercem, é um estudo analítico bastante apropriado que pode dar ênfase na conclusão de que a autoestima é fator importante a qualquer indivíduo que viva em meio aos outros, em sociedade, pois necessita notabilizar a si mesmo para poder valorizar aos outros.

Quem se sente amado e reconhecido acaba descobrindo por si mesmo seu próprio valor e, por consequência, seu próprio potencial. As relações afetivas no âmbito do trabalho tornam possíveis resultados satisfatórios em todos os sentidos. Por isso, profissionais das escolas precisam ser respeitados por seus gestores e por todos os técnicos da secretaria de educação. Eles também devem ser valorizados e elogiados sempre que necessário.

Então, sem dúvida, os técnicos precisam estar sempre com sua autoestima elevada, fortalecendo e enaltecendo o ensino, sentindo-se parte do processo, valorizado da forma como ele é. Vale ressaltar que o bem-estar também influencia no processo de transferência de informação, na realização dos comandos e orientações gerais e específicas. É preciso despertar o respeito e o carinho uns pelos outros, pois uma relação abalada pode provocar consequências graves para ambos.

$O$ gestor de setor também precisa estar bem e deve ter seu trabalho reconhecido. Como reação alguns profissionais inibem sua criatividade e sua vontade de poder inovar e fazer a diferença. Daí a importância de estar, e se sentir bem para que possa passar toda tranquilidade e motivação possível. 
[...] saber lidar com discordâncias para que elas não cresçam, saber entrar em fluxo na execução de um trabalho. Liderar não é dominar, mas, sim, a arte de convencer as pessoas a trabalharem com vistas a um objetivo comum. E, em termos de condução da própria carreira, talvez não haja nada mais essencial do que saber o que sentimos a respeito do quê - e que mudanças nos deixariam de fato satisfeitos com o nosso trabalho (GOLEMAN, 2011, p. 191).

Alguns símbolos da autoestima são importantes para o trabalho nas instituições tais como, usar os talentos e as aptidões (adequando quando necessário) para amar e estudar, ter um grau mínimo de autoaceitação e de orgulho próprio, reconhecer as necessidades e valorizar as vitórias fazendo valer os direitos e aceitar suas limitações, ter desejos e projetos pessoais, enfim, relacionar-se livremente com os outros, com autossuficiência e independência. Isto torna uma relação mais viável e sólida do ponto de vista da autonomia e da partilha de ideias, pensamentos e das aprendizagens.

É importante que todos os que fazem a educação estejam felizes no desempenho de suas funções, contribuindo positivamente para o crescimento da qualidade do serviço ofertado, do processo ensino-aprendizagem e da gestão democrática. É indispensável garantir um ambiente agradável e livre de tensões. Docentes, discentes e funcionários devem sentir prazer em estarem na instituição permitindo que a autoestima de todos esteja elevada para que se possa alcançar os objetivos propostos pelas diretrizes legais.

Portanto, a afetividade é primordial para se criar um clima positivo entre todos, superando dificuldades, enfrentando barreiras e encontrando novas formas de 
engrandecer o trabalho realizado e as relações interpessoais existentes, como forma de dar mais qualidade ao processo final de ensino-aprendizagem.

\section{A relação da afetividade na visão de alguns autores}

Complicado imaginar evolução sem afeto, trabalhar sem amor, sem propósito, ser educador é um ato de coragem, já dizia Chalita na publicação Educar é um ato de coragem e afeto:

[...] podemos afirmar que a educação é um ato de coragem e afeto. Coragem, porque não será a máquina ou o computador que substituirão o maestro da orquestra, o regente do processo de saber, a essência da educação: o professor. Nesse contexto, a educação torna-se ainda mais importante. Afeto, porque educar é um ato de amor ao próximo e a si mesmo. Quem educa não apenas ensina como, permanentemente, aprende. Crescem ambos os que estão envolvidos nesse diálogo, o mestre e o aprendiz. Porque se confundem na mesma pessoa, na troca de conhecimento. $\mathrm{Na}$ evolução pelo saber. No equilíbrio do amar e ser amado, do dar e receber (CHALITA, https://gabrielchalita.com.br/2003/05/27/educar-e-um-ato-de-coragem-e-afeto/)

As palavras do autor fortalecem o que se compreende a empatia e o afeto no processo de ensino aprendizagem. Pode até haver aprendizagem em relações frias, porém a conexão entre profissionais influencia na qualidade do serviço prestado.

Existe um pensamento equivocado onde se acredita que quanto maior o conhecimento, quanto maior o currículo menos envolvimento com os demais, e essa 
distância em determinados casos prejudica a relação no trabalho, pois nas relações mais próximas há uma ampliação do interesse pelas temáticas abordadas, soma-se ao saber técnico os saberes cotidianos. E nessa troca aproxima-se a teoria da prática e chega-se a melhores resultados.

Consoante Goleman (2011, p. 195) "imaginem as consequências para um grupo de trabalho em que um dos participantes não pode expressar sua raiva e não é sensível ao que sentem as pessoas à sua volta". Para que profissionais se sintam aptos para questionar e para colaborar é necessário que ele se sinta à vontade, pois em um ambiente afetivo a criatividade brota mais facilmente.

Na obra Pedagogia da Autonomia é enfatizado que:

Não temo dizer que inexiste validade no ensino em que não resulta um aprendizado em que o aprendiz não se tornou capaz de recriar ou de refazer o ensinado, em que o ensinado que não foi apreendido não pode ser realmente aprendido pelo aprendiz (FREIRE, 1996, p.26).

Sempre temos algo para aprender com as pessoas que convivemos, independente dos cargos que ocupam. A descrição de Rubéns Alves na publicação a arte de produzir fome:

Toda experiência de aprendizagem se inicia com uma experiência afetiva. É a fome que põe em funcionamento o aparelho pensador. Fome é afeto. O pensamento nasce do afeto, nasce da fome. Não confundir afeto com beijinhos e carinhos. Afeto, do latim "affetare", quer dizer "ir atrás". É o movimento da alma na busca do objeto de sua fome. É o Eros platônico, a fome que faz a alma voar em busca do fruto sonhado (ALVES, https://www1.folha.uol.com.br/folha/sinapse/ ult1063u146.shtml.) 
A motivação é algo imprescindível para uma gestão eficiente e humanizada, é como faca e queijo na mão para saciar a fome de conhecimento.

\section{Conclusão}

Observou-se neste trabalho que o relacionamento ruim em uma instituição é o caminho mais certo para se levar ao fracasso. Então, o profissional da contemporaneidade necessita exercitar o domínio das funções da Inteligência Emocional, porquanto convive em sociedade com elevado índice de exaustão emocional, dos quais as repercussões podem suscitar desgastes, que poderão causar entraves no desenrolar dos processos educacionais.

Assim sendo, investir no amor próprio e regular a inteligência emocional é ter habilidade para inferir as próprias emoções, tendo familiaridade com elas, compreendendo seus gatilhos direcionando a melhor forma de cuidar das emoções, tornando-se coadjuvante no processo de construção de instituições mais humanizadas.

Propõe-se que a gestão da instituição seja humanizada, justa e reconhecedora do trabalho dos técnicos e profissionais lotados nas escolas. Compreende-se que estes precisam se sentir bem e valorizados, com o entendimento de que por sua vez, não estão sozinhos, fazem parte de uma rede. Os colaboradores devem ser estimulados, considerados ativos e participativos e a relação afetiva entre todos precisa ser preservada sem prejuízo a nenhuma parte.

Portanto, um dos maiores desafios é estabelecer uma identidade entre técnicos, gestores, docentes e discentes é realçar que este conhecimento não está livre 
no espaço, mas, faz parte de uma cultura e de histórias, vivas e escritas diariamente. É fundamental compreender que técnicos da secretaria não são plateias, muito pelo contrário são protagonistas do futuro, suas decisões norteiam os trabalhos nas instituições de ensino e a sua competência para gerenciar sentimentos contribui para o resultado dessas ações atingindo de forma positiva ou negativa as pessoas que estão na roda da vida levando nessas instruções (dadas e recebidas) variáveis, para vivê-la, construí-la e ressignificá-la.

\section{Referências}

ALVES, R .A arte de produzir fome 9/10/2002 - 02h49 folha de São Pualo online. Disponível em https://www1. folha.uol.com.br/folha/sinapse/ult1063u146.shtml. Acesso em 24 out. 2021

CHALITA, G. Educação: a solução está no afeto. 12.ed. São Paulo: Gente, 1998.

G. Educar é um ato de coragem e afeto. Disponível em https://gabrielchalita.com.br/2003/05/27/ educar-e-um-ato-de-coragem-e-afeto/. Acesso em 240ut.2021.

CORREIA, J. P. S; MATA, V. E. A Inteligência Emocional e sua influência no Trabalho Remoto. FESPSP, 2020. Disponível em: https://www.fespsp.org.br/store/file_source/FESPSP/Documentos/Manuais/FESPSP\%20-\%20 GT\%2019\%20-\%20Vit\%C3\%B3ria\%20Evelyn\%20da\%20 Mata.pdf. Acesso em: 26 out. 2021.

BERTOLDI, A. D. Psicologia organizacional e do trabalho. Indaial: Uniasselvi, 2013. 257 p. Disponível em: https://www.uniasselvi.com.br/extranet/layout/request/ trilha/materiais/livro/livro.php?codigo=16337. Acesso em: 26 out. 2021. 
FREIRE, P. Educação e mudança. Tradução de Moacir Gadotti e Lílian Lopes Martin. Rio de Janeiro: Paz e Terra, 1983.

FREIRE, P. Pedagogia da Autonomia. 51.ed. São Paulo: Paz e Terra, 1996.

GOLEMAN, D. Inteligência emocional [recurso eletrônico] / Daniel Goleman; tradução Marcos Santarrita. Rio de Janeiro: Objetiva, 2011. Disponível em: https:// edisciplinas.usp.br/pluginfile.php/4133507/mod_resource/content/2/Inteligencia-emocional-Daniel-Goleman.pdf. Acesso em: 25 out. 2021.

LEITE, E.B. Lider de resultado: o poder da gestão que entende de gente, desenvolve pessoas e multiplica resultados. 2. ed. São Paulo: Gente, 2017, 184p.

SALLA, F. O Conceito de afetividade de Henry Wallon. novaescola@fvc.org.br. Outubro 2011. Disponível em: https://novaescola.org.br/conteudo/264/0-conceito-de-afetividade-de-henri-wallon. Acesso em: 25 out. 2021.

SPAGOLLA, R. P. AFETIVIDADE: POR UMA EDUCAÇÃO HUMANIZADA E HUMANIZADORA. Disponível em: http://www.diaadiaeducacao.pr.gov.br/portals/pde/arquivos/2343-8.pdf. Acesso em: 25 out. 2021.

TAIAR, E. M. M. de. A importância da afetividade para o aprendizado da criança. Web Artigos, [S.l.:s.n.], 2009. Disponível em: https://www.webartigos.com/artigos/a-importancia-da-afetividade-para-o-aprendizado-da-crianca/17619. Acesso em: 25 out. 2021.

TASSONI, E. C. M. Afetividade e aprendizagem: a relação professor-aluno. In: ASSOCIAÇÃO NACIONAL DE PÓS-GRADUAÇÃO E PESQUISA EM EDUCAÇÃO, 23, 2000. Caxambu, MG. Anais. Caxambu, MG: ANPED, 2000. Disponível em: http://23reuniao.anped.org.br/ textos/2019t.pdf. Acesso em: 25 out. 2021. 
VIEIRA, P. Poder e alta perfomace: o manual prático para reprogramar os seus hábitos e promover mudanças profundas em sua vida. São Paulo: Gente, 2017, 256p. VYGOTSKY, L. S. A formação Social da Mente. São Paulo: Martins Fontes, 1994. 


\section{A GESTÃO ESCOLAR EM MEIO A PANDEMIA DA COVID 19: DESAFIOS DO ENSINO APRENDIZAGEM NO CONTEXTO REMOTO \\ Mara Rubia de Araújo Dantas ${ }^{1}$ \\ Rita de Cassia Lopes Gomes² \\ Rosangela Cosmo Batista ${ }^{3}$ \\ Iury Torquato de Almeida ${ }^{4}$}

\section{Introdução}

A elaboração deste trabalho tem sua origem no curso de especialização em MBA Gestão Educacional Pública e Privada, o qual nos possibilitou a reflexão sobre diversas temáticas pertinentes à educação. Dentre elas, a que gerou mais inquietação foi o impacto da pandemia e suas consequências na vida de todos e, em específico, no processo de ensino aprendizagem dos estudantes.

1 Graduada em pedagogia - UVA; Especialista em Gestão Escolar - UVA; Especialista em Coordenação Pedagógica - UFC; Gestora Escolar do município de Maracanaú/CE;

E-mail: gestoramara@gmail.com

2 Especialista em ensino de língua portuguesa - UVA; Especialista em Gestão Escolar na área da educação - FALC; Graduada em Pedagogia - UVA; Gestora Escolar do município de Maracanaú/CE; E-mail: rita01coimbra@gmail.com

3 Especialista em Gestão Escolar e Coordenação Pedagógica - UVA; Graduada em Pedagogia - UVA; Gestora do município de Maracanaú/CE; Professora do município de Maracanaú/CE;

E-mail: rosangellabatista1@gmail.com

4 Graduado em Administração - FAK; Licenciado em Pedagogia - FAK; Especialista em Gestão de Projetos - ABED; Especialista em Psicologia Organizacional e do Trabalho - FAK; Especialista em Gestão Escolar - FAESL; Especialista em Docência do Ensino Superior - FAK; Especialista em Gestão e Tutoria - UNIASSELVI; Mestre em Gestão de Negócios Turísticos - UECE; Doutor em Ciências da Educação - USC/PY; E-mail: iuryt.almeida@gmail.com 
Vivenciarmos experiências, dificuldades e grandes desafios no período das aulas remotas, que fundamentaram a decisão de assumir o desafio de aprofundar este tema, visto que a situação pandêmica é algo novo e que todos tivemos que aprender a conviver com os desafios inerentes ao processo de aprendizagem no sistema remoto.

Para a construção do referencial teórico utilizou-se como fundamentação as ideias, dos autores, Daniel Goleman, Celso Vasconcellos, Cipriano Luckesi, documentos oficiais do observatório da pandemia no Brasil e da organização mundial da saúde.

A presente pesquisa tem por objetivo refletir sobre as contribuições da gestão diante dos desafios, na construção possível da aprendizagem no ensino remoto em tempo pandêmico, a partir de um estudo de natureza bibliográfica e a consolidação de dados provenientes de entrevistas com os segmentos envolvidos professores, pais e alunos.

Para a realização da investigação dessa temática temos por objetivos específicos: identificar as principais dificuldades vivenciadas pelos docentes em sua prática; conhecer as necessidades de aprendizagens dos educandos e as dificuldades encontradas pela família; propiciar orientações sobre as ferramentas tecnológicas para a comunidade escolar buscando minimizar as dificuldades encontradas para a melhoria do processo ensino aprendizagem.

$O$ interesse da pesquisa se insere no fato de que, com o surgimento da pandemia da Covid-19 repentinamente, surgiram repercussões não apenas de ordem biomédica e epidemiológica em escala global, mas também impactos sociais, econômicos, culturais políticos. 
Em relação ao impacto na educação, vivenciamos um grande desafio diante de um novo contexto envolvendo a gestão escolar, sendo necessário fazer mobilizações com todos os segmentos, buscando reinventar uma prática educacional possível através da utilização de ferramentas tecnológicas diversas, principalmente priorizando a dimensão humana, visto que foi a mais afetada, influenciando diretamente nas emoções.

\section{Referencial teórico}

Diante da pandemia da Covid-19 que afetou o mundo e trouxe consequências gravíssimas e com diferentes impactos na vida das pessoas em todas as dimensões. Visto que é um algo novo para todos, exigiu-se que a sociedade mudasse completamente o seu modo de vida. Tendo um cenário na saúde trágico de doentes e mortes incessantes, passou a ser necessária a adoção de várias práticas de prevenção como o uso de máscaras, distanciamento social, álcool gel e higiene constante nas ações cotidianas.

Nesse sentido, o isolamento social foi a principal ação onde impactou e gerou consequências severas. Ressaltamos em específico o processo educacional em que o ensino aprendizagem acontece através da interação presencial no ambiente escolar. Exigiu de todos da educação um novo olhar e a perseverança para reinventar novos e possíveis caminhos para que os educandos tivessem acesso às aprendizagens em tempos remotos. Principalmente a reconstrução de olhares e ação dos docentes diante desse novo contexto.

Diante do contexto atual, temos hoje uma ferramenta na sociedade contemporânea que é um suporte 
imprescindível nas aulas remotas: A evolução tecnológica e as transformações dinâmicas e cada vez mais rápidas e eficazes. Dessa forma tivemos que desenvolver as habilidades de "Aprender a Aprender" juntos.

A princípio houve um período de adaptação para se adequar as mudanças e superar as dificuldades, principalmente a ansiedade e os sentimentos de angústia e insegurança, ocasionados por tal situação, para só então conseguir utilizar as tecnologias educacionais remotas com destreza. Logo, após o período de adequação foi possível usufruir tudo aquilo que as tecnologias educacionais têm para nos ofertar, as aulas foram substituídas por aula remotas com a utilização de celulares, ferramentas mais próximas da realidade do aluno, proporcionando a continuidade do aprendizado com qualidade, e respeitando as medidas de segurança. A utilização da tecnologia em favor da educação durante a pandemia do Covid-19 foi uma estratégia de grande contribuição para o âmbito da educação. As instituições de ensino substituíram as aulas presenciais por aulas remotas, por aplicativos e plataformas digitais que possibilitaram a realização de encontros de diversas pessoas em salas virtuais, além de ofertar várias maneiras de comunicação, tais como: vídeos-chamadas, áudios e chats online, proporcionando a interação entre os docentes e estudantes em tempo real, mesmo à distância.

Além do exposto, a implementação das aulas remotas enalteceu a desigualdade social existente no Brasil. Visto que nem todos têm acesso à internet, computador, smartphone e de um local silencioso para a realização de seus estudos, onde ainda existe no Brasil uma vulnerabilidade de renda, moradia e saneamento 
(IBGE, 2018). Ademais, com o surgimento do isolamento social essa situação se apresenta ainda mais explícita (FEITOSA et al., 2020).

\section{Os problemas emocionais causados pelo impacto do Coronavírus e o isolamento social}

Segundo o psicólogo e jornalista Daniel Goleman (1999), considerado o principal pesquisador contemporâneo dedicado a pesquisar o conceito de inteligência emocional, definida por ele como "a capacidade de identificar nossos próprios sentimentos e dos outros, de nos motivarmos e gerirmos os impulsos em nós e em nossos relacionamentos". Ele ficou famoso mundialmente ao defender que lidar com as emoções é fundamental para o desenvolvimento de um indivíduo, pois não há uma loteria genética que predestina vitoriosos e fracassados no jogo da vida.

Sua tese é de que a inteligência emocional promove diminuição dos níveis de ansiedade e estresse; maior empatia pelo próximo; mais equilíbrio emocional; maior clareza nos objetivos de vida e capacidade de tomada de decisão; melhor gestão do tempo; aumento de produtividade e de comprometimento com metas; e maior autoestima e autoconfiança. Além disso, defende que essa inteligência pode ser aprendida e desenvolvida, dependendo de um exercício cotidiano.

Com base nesses conceitos, compreendemos que não fazer julgamento de valor para cada emoção facilita seu entendimento e acolhimento, além de aumentar a probabilidade de que o ser humano fale sobre o que está sentindo ou pensando com mais abertura. Todas as emoções são entendidas como importantes para a ma- 
nutenção da vida, com a consciência de que não podemos controlar o que sentimos, mas podemos escolher o que fazer com os nossos sentimentos.

Goleman afirma que a parte cerebral que sustenta a inteligência emocional é uma das últimas a amadurecer anatomicamente. Para ele, como a neuroplasticidade molda o cérebro conforme a repetição das experiências, faz sentido investir em práticas regulares e sistemáticas que estimulem o autoconhecimento, a empatia e o relacionamento. Para tanto se faz necessário o conhecimento dos cinco pilares da Inteligência emocional.

1. Autoconhecimento: conhecimento sobre o que se sente, sobre os próprios impulsos e fraquezas. É a base para uma boa intuição e tomada de decisão, bem como uma "bússola moral". As emoções que ficam fora do limiar da consciência podem impactar poderosamente os comportamentos;

2. Autorregulação: capacidade de escolher respostas e não reagir apenas por impulso, ou seja, cuidar das emoções de forma que não sejam prejudiciais para a pessoa ou para a situação. Essa autogestão é o que ajuda a sintonizar as vivências emocionais com o processo de aprendizagem, facilitando a recuperação das perturbações da vida, sem reprimir os sentimentos indesejados e incômodos, e saber adiar as satisfações quando necessário;

3. Automotivação: capacidade de dirigir as emoções a serviço de um objetivo ou realização pessoal. Nas palavras de Goleman (1999): "As pessoas com altos níveis de esperança têm certos 
traços comuns, entre eles o poder de motivar-se, e sentir-se com recursos suficientes para encontrar meios de atingir os seus objetivos, ter flexibilidade bastante para encontrar meios diferentes de chegar às metas, e ter o senso de decompor umas tarefas formidáveis em outros menores, mais manejáveis";

4. Empatia: capacidade de compreender e considerar os sentimentos de outros. Isso permite maior sintonia com o mundo;

5. Habilidades sociais/de relacionamento: capacidade de relacionar-se melhor, comunicando-se de maneira clara e atenta às demandas e postura do outro. É colocar todos os elementos acima coordenados para facilitar os encontros sociais.

A partir dessa premissa, podemos refletir como é difícil e complexo lidar com as emoções e em especial em tempos de pandemia da Covid-19, nas escolas municipais no município de Maracanaú, onde de uma hora para outra tudo mudou e se fez necessário um repensar das ações para superar as dificuldades da aprendizagem com aulas remotas. Professores tiveram que lidar com novas tecnologias, pais passaram a acompanhar as atividades dos filhos em seus domicílios sem ter as habilidades acadêmicas necessárias, para dar um melhor suporte na rotina escolar e para o aluno surgiu à instabilidade e a incerteza no formato das aulas e com o surgimento de medidas sanitárias, pelas organizações de saúde para conter a Covid19, surgiu os lockdowns promovendo o isolamento social, uso de máscara para diminuir a contaminação, gerando um clima de medo e 
comoção social. Todos esses fatores trouxeram vários problemas emocionais o que levou a gestão escolar a um estado de exaustão, na busca de resolver todas as situações em tempo hábil mesmo de maneira intuitiva e sem os conhecimentos necessários no que se refere ao uso das técnicas da inteligência emocional.

Nesse sentido, o papel da gestão escolar em tempos de pandemia se configura como uma atividade que exige do gestor, pensar estratégias para que toda a comunidade escolar encontre uma solução para as dificuldades encontradas, sem perder o foco principal que é a aprendizagem dos alunos e para que os objetivos sejam alcançados. Todos os conflitos e dificuldades precisam ser trabalhados de forma individual e coletiva na busca de soluções plausíveis.

A pandemia da Covid-19 trouxe oportunidades de lidar com as emoções propiciando um aprendizado na tomada de decisões da gestão escolar, isso se tornou visível em relato feito pelos diversos segmentos da escola, por ocasião de um questionário elaborado durante a experiência vivenciada ao longo do período de aulas remotas.

\section{A gestão democrática e sua atuação com os colegiados em prol da efetivação das ações nos desafios em meio a Pandemia}

Segundo Eloisa Lück (2006), escola é o local possível de proporcionar uma educação de qualidade a todos, é neste lugar, onde se formam indivíduos críticos, que buscam exercer sua cidadania, com perspectivas de cumprir seu papel frente à sociedade em que vive. A tarefa pedagógica e administrativa, não é uma 
tarefa simples, requer raciocínio, observação, replanejamento, busca de novos caminhos para os erros e fracassos. Sendo assim, o ambiente escolar necessita de democracia, a ponto de que todos os envolvidos possam participar das decisões de forma consciente, para isso é preciso disposição, trabalho em equipe e redistribuição de responsabilidades, o que irá promover o sucesso da escola. Lück (2006, p.54) nos alerta que "democracia e participação são dois termos inseparáveis, à medida que um conceito remete ao outro." Para que a gestão democrática realmente ocorra devemos pensar primeiramente em intervenções no Projeto Político Pedagógico da escola, dando abertura para maior implementação de projetos, com a participação efetiva da comunidade escolar como a implementação das instâncias democráticas: conselho escolar, associação de pais e mestres de modo que eles possam influenciar na gestão, de modo que todos tenham a oportunidade de liberar seu potencial a ponto de propor soluções aos problemas enfrentados no ambiente escolar.

Compreende-se que o principal objetivo da gestão democrática é a construção de políticas educacionais engajadas na formação do indivíduo, não se tratando apenas da função do gestor, mas sim de todos os indivíduos inseridos no âmbito educacional. Para que todos estejam engajados na proposta é necessário um planejamento, com propostas articuladas, coletivas e responsáveis pelas decisões tomadas para melhoria e organização da escola. Segundo Lück (2009) planejamento é: Planejar constitui-se em um processo imprescindível em todos os setores da atividade educacional. É uma decorrência das condições associadas à complexidade da educação e da necessidade de sua organização, assim 
como das intenções de promover mudança de condições existentes e de produção de novas situações, de forma consistente. $O$ planejamento educacional surgiu como uma necessidade e um método da administração para o enfrentamento organizado dos desafios que demandam a intervenção humana. Cabe destacar também que, assim como o conceito de administração evoluiu para gestão, também o planejamento como formalidade evoluiu para instrumento dinâmico de trabalho (LÜCK, 2009 p. 32). Propor este envolvimento e orientação desenvolve no contexto escolar resultados positivos na formação dos educandos. Após a elaboração deste planejamento é necessário avaliar este plano para compreender seus resultados, e insucessos propondo uma reflexão sobre o que deve ser mudado e melhorado.

Partindo desse pressuposto de que a gestão democrática se faz com a participação de todos onde todos tem vez e voz, que os gestores das escolas municipais do município de Maracanaú, resolveram por embasamento teórico e prático munidos do sentimento e da necessidade emergencial elaborar estratégias para contemplar a aprendizagem dos alunos mesmo que com aulas remotas, durante o período de pandemia da Covid-19. Essas ações foram efetivadas com a participação dos segmentos escolares tais como gestão, professores, pais, alunos e funcionários de forma virtual para refletir como cada um dos segmentos poderia colaborar de maneira mais efetiva em relação ao ensino aprendizagem. Também foi organizado planejamentos pedagógicos sistemáticos com os discentes e o núcleo gestor, com a colaboração e acompanhamento da Secretaria de Educação com o intuído dar um maior suporte nas ações pedagógicas. 


\section{O papel da gestão no desafio de construir estratégias desenvolvidas no processo educacional em tempo Pandêmico}

A gestão escolar buscou construir uma prática possível e efetiva durante o ensino remoto. Além de fazer os encaminhamentos conforme as orientações dos documentos legais (resoluções; portarias) também da Secretaria de educação, nós gestores escolares também organizamos as nossas ações diante do contexto. Diante de situações novas e imprevisíveis, que gerou a insegurança e a resistência dos docentes e familiares, foi necessário como líder organizar uma rotina escolar e um plano de ação possível. Primeiramente percebemos a necessidade de trabalhar a sensibilização e fortalecimento emocional que consequentemente foi atingido deixando as pessoas fragilizadas, com medo, anseios e resistentes ao novo.

Outra ação foi desenvolver momentos de escuta com os segmentos envolvidos, pois os mesmos estavam precisando de atenção e alguém para ouvir, de maneira desprendida e de muita compreensão. Foram momentos enriquecedores de troca de experiências, angústias e principalmente o fortalecimento do vínculo afetivo.

Então se fez necessário organizar um planejamento que contemplasse ações que minimizassem os problemas em virtude da pandemia e efetivasse o ensino aprendizagem. E conforme aponta Vasconcellos (2000, p. 79), quando diz que

"O planejamento enquanto construção-transformação de representações é uma mediação teórica metodológica para ação, que em função de tal mediação passa a ser consciente e intencional. Tem por finalidade procurar fazer algo vir 
à tona, fazer acontecer, concretizar, e para isto é necessário estabelecer as condições objetivas e subjetivas prevendo o desenvolvimento da ação no tempo." (VASCONCELLOS, 2000, p. 79).

O planejamento construído contemplou a construção de um plano de ações que contemplou a realização de encontros de sensibilização trabalhando as potencialidades do grupo, valorizando e também construindo um espaço de confiança e de apoio para se sentirem seguros e fortalecidos para desenvolver as atividades propostas e planejadas.

Outro grande desafio diante de uma pandemia, foi a reconstrução de um novo currículo, onde priorizasse as habilidades necessárias de cada turma, sem deixar vácuo e fossem desenvolvidas com eficácia. Pois, o Currículo é fundamental e o fio condutor de todo processo na construção da aprendizagem. E este por ser intencional e sistemático implica na elaboração de um programa de experiências pedagógicas a serem realizadas as atividades propostas.

Nesse sentido, temos que compreender o conceito de currículo, que conforme afirma Doll et al. (1997, P.200) "Currículo vem do latim currículo (do verbo currere = correr). Refere-se tanto à proposta feita pela instituição quanto ao caminho, ao trajeto que o discente percorre no período de sua formação escolar. Ao invés de ser pensado como uma pista de corrida, onde o percurso já previa e definitivamente estabelecido, cabendo pouquíssima opção.”

Nesse sentido, por ser flexível a realidade em que se está inserido, foi necessária a priorização de habilidades e conhecimentos diante a realidade pandêmica atualmente. 
Foram realizados virtualmente encontros coletivos para construir as ações e estratégias para o processo didático de aprendizagem dos alunos, como também a família. Ressaltamos também o apoio e a parceria da Secretaria de Educação com a realização de Formação Continuada aos docentes e reuniões contemplando orientações fundamentais para a eficácia em todo o processo e sendo assim, fez-se necessário um novo olhar diante da pandemia em relação ao currículo a ser trabalhado, priorizando as habilidades necessárias a serem desenvolvidas com os educandos.

Dessa forma as estratégias de ensino foram planejadas coletivamente, por uma atuação efetiva da gestão com o saber-fazer do professor através do uso das tecnologias como ferramentas de aprendizagem, os mesmos se viram tendo que transformar espaços físicos de suas casas em salas de aula. Tiveram que aprender a lidar com as tecnologias atuais para tornar mais interessantes e não arriscar perder o aluno. Muitos professores não tiveram incentivos financeiros para adquirir materiais tecnológicos e se viram tendo que se virar sozinhos para continuar trabalhando e fazendo garantir ao aluno o direito de estudar.

Foi utilizado especificamente o canal do WhatsApp, tendo que ser contemplados nesse processo do novo normal, os embasamentos teóricos necessários para desenvolver suas ações, de papéis diferentes, de saberes diversos, podendo assim buscar um encontro eficaz cujo fruto fosse a construção de uma prática pedagógica mais consistente, enriquecida e criativa. Para isso foram formados grupos por turmas no sentido de realizar a interação e orientação das atividades para os alunos, efetivando a parceria entre escola e família. 
Assim sendo, para desenvolver esta nova concepção pedagógica foi necessária a intervenção de uma gestão dinâmica e de forma coletiva capaz de articular e buscar superação de obstáculos e resistência, com foco na participação entre os segmentos envolvidos e fazer se cumprir a função social da escola sendo o desenvolvimento das potencialidades físicas, cognitivas e efetiva do indivíduo, capacitando-o e tornando-o cidadão participativo na sociedade em que vive de modo remoto.

Com os índices da covid em queda, foram pensadas estratégias de planejamento aos profissionais da educação com o apoio da secretaria de educação, para um desafio maior ainda que seja o retorno responsável das aulas presenciais, dando todo apoio possível aos envolvidos, pois se acredita que crianças e jovens devem ser desenvolvidos em todas as suas dimensões. É Um grande desafio da gestão, nesse contexto de pandemia e numa perspectiva de um retorno presencial das aulas, pois não envolve apenas os cuidados com os protocolos sanitários, é principalmente acolher todos com tudo que trazem em todas as suas dimensões.

\section{Considerações finais}

Compreendemos que ao longo da construção deste artigo, que a atuação do núcleo gestor é imprescindível no desenvolvimento das ações propostas em prol do sucesso do ensino aprendizagem diante de uma inesperada pandemia.

Dessa forma, foi preciso desenvolver ações para minimizar as fragilidades e os desafios durante todo o processo. Percebemos que por ser um contexto novo, 
fizeram-se necessários uma reflexão de uma nova prática educativa, adaptação e priorização do currículo, aprender ferramentas tecnologias que atendessem todas as necessidades dos nossos alunos.

Nessa perspectiva, nós gestores temos a realização de ações dinamizadoras que possibilitam a ressignificação e melhoria do processo de ensino aprendizagem, minimizando os obstáculos, visando a garantia do sucesso escolar.

Com essa pesquisa, esperando estar contribuindo para a reflexão sobre a organização do fazer pedagógico nesse novo contexto pandêmico, desejamos que se traduza na construção de novos saberes.

\section{Referências}

DOLL, JÚNIOR, W. E. Currículo: uma perspectiva pós-moderna. Porto Alegre: Artes Médicas, 1997.

FEITOSA, Ankilma do Nascimento Andrade et al. TECNOLOGIAS EDUCACIONAIS EM TEMPOS DE PANDEMIA: RELATO DE EXPERIÊNCIA: EDUCATIONAL TECHNOLOGIES IN PANDEMIC TIMES: EXPERIENCE REPORT. Brazilian Journal of Production Engineering-BJPE, p. 166-172, 2020.

GOLEMAN, Daniel. O Cérebro e a Inteligência Emocional: Novas Perspectivas. Objetiva, 2012.

GOLEMAN, Daniel. Trabalhando com a inteligência emocional. Objetiva, 1999.

IBGE - INSTITUTO BRASILEIRO DE GEOGRAFIA E ESTATÍSTICA. Síntese de Indicadores Sociais - 2018. Rio de Janeiro, IBGE, 2018.

LÜCK, Heloísa. A gestão participativa na escola. 9. ed. Petrópolis: Vozes, 2006. 
LÜCK, Heloísa. Dimensões de gestão escolar e suas competências. Curitiba: Editora Positivo, 2009.

VASCONCELLOS, Celso dos Santos. Planejamento: projeto de ensino-aprendizagem e projeto político-pedagógico. São Paulo: Libertad, v. 1, 2000.

VASCONCELOS, Celso dos Santos. Coordenação do trabalho pedagógico. Do projeto político-pedagógico ao cotidiano da sala de aula. São Paulo: Libertad, 2007. 
EDUCAÇÃO EM TEMPOS PANDÊMICOS: DESAFIOS

SOCIAIS E EMOCIONAIS E OS IMPACTOS DE AÇÕES

SOCIAIS NO PROCESSO DE ENSINO APRENDIZAGEM

NA EMEIEF JOSÉ ASSIS DE OLIVEIRA

(MARACANAÚ-CE)

\author{
Antônio Flávio de Sousa ${ }^{1}$ \\ Cristiane Silva Lima² \\ Francisca Ticiane Gondim da Costa Jales ${ }^{3}$ \\ Iury Torquato de Almeida ${ }^{4}$ \\ Rita Cristiane de Oliveira Comes ${ }^{5}$
}

1 Graduação em Licenciatura em Física pela UFC. - Graduação em Ciências Náuticas pela Escola de Formação de Oficiais da Marinha Mercante. - Pós-Graduação Lato Sensu em Gestão Escolar Integrada e Práticas Pedagógicas pela Universidade CÂNDIDO MENDES. - Pós-Graduação: Mestrado Profissional em Ensino de Física pela Universidade Estadual do Ceará

2 Pós graduada em psicopedagogia pela Universidade estadual Vale do Acaraú UVA, graduada em pedagogia /UVA e professora efetiva da Educação Básica do município de Maracanaú-CE,

E-mail alex-cris22@hotmail.com

3 Formação Pedagogia - Universidade Estadual do Ceará, pós graduação em Psicopedagogia Clínica e Hospitalar - Faculdade Vale do Jaguaribe, Mestranda em Avaliação em políticas públicasMapp UFC

4 Graduado em Administração - FAK; Licenciado em Pedagogia - FAK; Especialista em Gestão de Projetos - ABED; Especialista em Psicologia Organizacional e do Trabalho - FAK; Especialista em Gestão Escolar - FAESL; Especialista em Docência do Ensino Superior - FAK; Especialista em Gestão e Tutoria - UNIASSELVI; Mestre em Gestão de Negócios Turísticos - UECE; Doutor em Ciências da Educação - USC/PY; E-mail: iuryt.almeida@gmail.com

5 Especialista em Docência do Ensino Superior - Facesma; Gestão Escolar e Coordenação Pedagógica - Falc; Psicopedagogia Clínica, institucional e hospitalar - CETREDE; Gestão e Políticas Públicas - Fak. Graduada em Licenciatura Pedagogia - UVA; Professora da rede municipal de Maracanau há 33 anos e de Fortaleza há 20 anos; Atualmente Diretora Acadêmica da Faculdade Cesma de Maracanaú- FACESMA; E-mail: cristiane@facesma.com.br 


\section{Considerações Iniciais}

A Pandemia mundial provocada pela coronavírus é atualmente um dos maiores problemas sociais existentes em nosso mundo, isso não só pelos impactos econômicos que ela vem causando a todos os países, mas também por conta dos diversos transtornos emocionais que ela agravou ou criou no início de 2020 até o atual momento do ano de 2021. Uma das maiores áreas afetadas por tais questões sociais são a área da educação, ao se afastarem do ambiente escolar as crianças começaram a perder o vínculo não só com a escola como também com os professores, além da falta de ânimo para continuar com a rotina de estudos normalmente; os pais atualmente são os que mais sofrem com o sistema educacional atual muitas vezes por não possuírem tempo para ajudar os filhos e/ou por estarem ocupados demais com a crise financeira que a pandemia global tem causado. Diante desse processo percebe-se a inviabilidade de algumas famílias participarem do processo de ensino aprendizagem e continuarem nessa caminhada escolar.

Iniciamos o ano de 2020 de forma presencial e fomos ao longo do mês dialogando diante de um ano normal como todos os outros que o antecederam, porém, ao longo de março, surgiu um pressuposto que nos forçou a pensar em um novo modelo de educação, diferente da sala de aula tradicional, onde o professor está diante dos alunos e pode seguir seu planejamento de forma sistemática, nos vimos estagnados com um vírus invisível e sem perspectiva de retorno fazendo por onde todos os segmentos da educação pensasse no sistema todo para atender de forma diferenciada o mesmo 
público onde estava inserido fisicamente na escola. Foi travada então uma nova forma de educar, com diferentes metodologias e formas de atender ao aluno, pensando em uma forma para que o aluno não perdesse o vínculo com a escola. Durante o isolamento, um grau muito grande de adaptabilidade foi exigido de adultos, crianças e jovens. Esse processo causou impactos emocionais em todas as pessoas, muitas famílias de nossa escola não possuíam sequer um celular para acompanhar as aulas, ou até um nível de escolaridade que lhes favorecesse esse acompanhamento. Era tudo muito novo e todos estavam em fase de aprendizado, cada um tentando de forma cautelosa desenvolver uma maneira que pudesse ser confortável para seguir, mesmo sabendo que por inúmeras vezes houve receio em diferentes patamares de educadores em usar suas internets, celulares, imagens, dentre outros e, por outro lado, estavam as famílias, sofridas com os impactos da crise econômica e emocional.

Houve, portanto, uma sensibilização em massa na escola, com vídeos, áudios e em diferentes circunstâncias para que esse processo educacional seguisse de forma remota, sendo pertinente ressaltar que vários reflexos da pandemia foram sentidos no período e demonstraram que as crianças e jovens eram os mais vulneráveis diante da situação porque ainda não estavam maduros emocionalmente, manifestando em conseguinte, sentimentos de tristeza, ansiedade e depressão. Sabe-se que foram muitas perdas e esse sofrimento psíquico sentido principalmente pelos jovens de nossa comunidade escolar pode ser comprovado diante de mudanças de padrão de comportamento, como a hiperatividade, com manifestações de raiva, agressividade 
e inquietação; ou a passividade exagerada, com apatia, tristeza e até abandono de hábitos funcionais.

A pertinência do tema justifica-se nos problemas emocionais e sociais vivenciados pelos professores da escola e famílias durante o período de isolamento e nas ações sociais onde a escola José Assis de Oliveira se mobilizou para minimizar os problemas que foram surgindo ao longo do percurso.

À medida que a pandemia da Covid-19 atingiu a educação em praticamente todo mundo, e seus impactos nos fizeram sentir indubitavelmente na educação a curto, médio e longo prazo, foi-se exigido uma readaptação e redesenho do sistema educacional, portanto o artigo em suma, objetiva-se em analisar os impactos da pandemia na educação, bem como evidenciar os desafios sociais e emocionais, e os pormenores causados à educação ao longo do processo de ensino aprendizagem, bem como situações utilizadas no enfrentamento a esta excepcional situação. Como procedimento metodológico utilizou-se pesquisa bibliográfica, enquanto visa proporcionar amplo domínio do tema ao pesquisador, facilitando a reflexão sobre o assunto proposto. Deste modo, buscar-se-á apresentar conhecimento retirado das bibliografias as mais recentes e consistentes referentes à aspectos que tangenciam o objeto do trabalho.

A EMEIEF José Assis de Oliveira precisou se adaptar aos novos ditames sociais impostos pela pandemia de Coronavírus. Após um período de suspensão das aulas, algumas instituições e redes de ensino entenderam ser viáveis e oportunas ministrar ensino remoto, tendo em vista as incertezas quanto ao fim da pandemia (ou pelo menos o seu controle) e o receio de perda do ano 
letivo e dos conteúdos aprendidos, preocupações totalmente pertinentes (BOTO, 2020).

Se atualmente a única forma de acesso à educação é por meios virtuais, o direito ao acesso à educação passa diretamente pelo direito ao acesso às tecnologias necessárias para isso, mas a realidade tem trazido desafios. Se, por um lado, a educação à distância é uma forma de garantir a educação de muitos estudantes resguardando a saúde da população, por outro lado, a educação via virtual pode segregar uma parcela de alunos, desfavorecidos economicamente (ВОTO, 2020).

\section{Histórico da EMEIEF José Assis de Oliveira, localizada no Maracanaú-CE}

A EMEIEF José Assis de Oliveira está situada na Rua Paulo Afonso, 4259 - Parque Jari - Maracanaú-Ce, de frente ao IV Anel Viário, em uma região que carece de muitos serviços de infraestrutura. A Escola situa-se na ADL VI e sua entidade mantenedora é a Prefeitura de Maracanaú por meio da Secretaria de Educação, dividida em dois prédios (SEDE e ANEXO). A SEDE, a qual é situada na Rua Paulo Afonso, principal via do Parque Jari, embora muito carente de uma estrutura asfáltica e o Anexo, que fica situado a 2,5KM de distância da escola, próximo ao Final da Linha de ônibus Canidezinho Urucutuba, mais precisamente na Rua Santo Antônio, 265 - Parque Jari. A sede e anexo juntos possuem cerca de 900 alunos, atendidos desde a creche de 3 anos até o Nono Ano do Ensino Fundamental, destacamos que o Ensino Fundamental também é oportunizado na modalidade EJA no Turno Noite. Ressaltamos que desde 2017 resgatamos na EMEIEF José Assis de Oliveira em par- 
ceria com o Estado, a EJA Médio, tendo hoje pouco mais de 100 alunos maiores de 18 anos que na SEDE de nossa escola no Turno Noite por meio da parceria com a EEM Eudes Veras concluem a Educação Básica na Modalidade EJA.

Temos na SEDE e no ANEXO, área administrativa com Coordenação e Secretaria escolar. Temos em ambos os espaços, sala dos professores, cantina escolar e pátio coberto e área descoberta para recreio, sendo que no anexo tudo é bem reduzido e mais precário, urgente e necessária uma reforma geral no prédio, o que é inviável, por o espaço ser alugado. Na sede temos a sala de AEE, LIEM, espaço destinado às atividades de contraturno, quadra esportiva e depósito de material, além de uma considerável área não construída que pode ser utilizada com inúmeras atividades, bem como com ações do poder público municipal que favoreçam a integração da escola com a comunidade do entorno, uma sugestão da escola para o poder público é a construção de uma academia de ginástica popular. A Escola Municipal José Assis de Oliveira está sendo gerida atualmente pelos professores Márcio Roque Cordeiro, Antônio Flávio de Sousa, Beatriz Dias Sousa, Edinir Silva Teixeira, Francisca Ticiane Gondim Costa Jales. No anexo da escola contamos com a valiosa coordenação da Professora Cristiane Silva Lima. Nossa Secretária escolar é a servidora Tereza Alves da Penha. A escola possui mais de 25 servidores entre terceirizados e servidores públicos. Conta com um quadro docente de 58 professores e possui quatro estagiários de nível médio e uma estagiária de nível superior. Contamos com o serviço de laboratório de informática (LIEM), com o atendimento educacional especializado (AEE) e com ações de tem- 
po integral por meio do programa novo mais educação, além do serviço de assistência ao Professor Alfabetizador por meio do Programa Mais Alfabetização.

A missão desta escola é proporcionar com equidade um ensino de qualidade para todos os que se beneficiam do serviço educacional por ela prestado e tem como visão de futuro formar cidadãos críticos, ativos e conscientes de seu papel junto à sociedade, de modo a lutar para ela ser justa e solidária.

\section{Desafios sociais e emocionais na comunidade escolar da EMEIEF José Assis de Oliveira, causados pela pandemia da Covid-19}

Logo ao iniciar a pandemia fora tudo novo e não se tinha previsão de quanto tempo todos ficariam fora de sala de aula, fora cogitado uma volta breve, porém a evolução da doença fechou as portas de todas as aglomerações, sendo pertinente ressaltar que a educação a priori iniciou a busca de formas para que o aluno não perdesse o vínculo com a escola.

Com o fechamento das escolas, os profissionais da escola se viram desafiados a encontrar novos caminhos para o ensino-aprendizagem de crianças, jovens e adultos. Ciente de que a educação é fundamental para que todas as pessoas tenham a oportunidade de alcançar o seu melhor como seres humanos, enumerou-se uma série de fatores que poderia desafiar o processo de ensino aprendizagem nesse momento de dificuldade $e$ perdas em todos os segmentos e etapas da educação.

Uma das principais preocupações nesse momento, além da aprendizagem e cumprimento do currículo escolar, foi o apoio às famílias em sua trajetória deste 
momento, tendo em suma a grande importância diante dos problemas que impactam a participação nas atividades escolares. Sabendo que esse acolhimento é necessário para que as famílias compreendam que a escola está além de somente organizar e efetuar um currículo, que ela tem papel fundamental na formação integral do aluno e que nesse momento onde se está vivenciando, esse ambiente tornou-se um dos elos mais importantes na parceria com o colegiado.

Nossa escola não é um espaço só de transmissão de conhecimento, ela perpassa pela organização e atuação social, ética, política e estética do aluno, repercutindo em suas escolhas como cidadão em formação, sendo âncora e detectando os principais desequilíbrios na comunidade onde está inserida, trabalhando de forma efetiva com as famílias de maior vulnerabilidade em uma rede de apoio na busca de uma melhor qualidade emocional e na promoção de uma equidade social.

Parafraseando Kenski (2012), ao citar o filósofo francês Jean- François Lyotard, "[...] o grande desafio da espécie humana na atualidade é a tecnologia [digital]". E mais do que isso, o uso e a real democratização da internet. Esse ainda é, e vai ser por algum tempo, o maior dos desafios a ser enfrentado, pois, atualmente, temos uma rede que, tem tese, está democratizada, mas não está acessível a todos os brasileiros

O eco que emanava das famílias era o pedido de orientação, apoio e compreensão com tudo que estava acontecendo, sabendo serem inúmeros os fatores que afastam suas crianças da interação, tais como a falta de internet, a quantidade de celulares por famílias, a falta de escolaridade dos pais, a falta de mantimentos para poderem manter-se, a violência doméstica, dentre ou- 
tros fatores que nos fora adormecido no olhar e sensibilidade. A escola como órgão de acolhimento e aprendizagem precisou reinventar-se junto a comunidade escolar para que pudesse em sua atuação amparar a todos os casos e como pressuposto disso foi moldando ações para minimizar os entraves da pandemia para que os prejuízos da mesma a longo prazo fossem reparados ou minimizados de forma gradativa e contínua.

\section{Educadores da escola José Assis de Oliveira e as barreiras frente à aprendizagem na Pandemia}

A modalidade de aulas virtuais não é uma novidade que surge junto a pandemia, no entanto, diante da interrupção abrupta que ocasionou o fechamento das escolas causada pelo surto do novo Coronavírus, ganhou destaque. Assim, após o início da pandemia, o modelo de oferta de aulas virtuais se expandiu devido aos argumentos que destacam a necessidade de dar continuidade às aulas, diante da inviabilidade dos encontros presenciais nesse contexto (SENHORAS, 2020).

Dessa forma, educadores precisam de alguma forma reorganizar-se. Reinventar-se em um processo em que a interação seria de forma tecnológica, sem a presença do aluno, sem poderem observar onde estavam as dificuldades ao exercer o ofício. Firmou-se, portanto, uma complicada e oportuna reflexão. Como os estudantes iriam aprender sem poderem dialogar, perguntar, expressar suas dúvidas? Diante disso, pode-se perceber a fragilidade do ensino remoto, mas optar por ele, pelo menos para minimizar os prejuízos que seriam irreparáveis se a educação estivesse parada e os alunos tivessem perdido o vínculo com a escola. 
Logo, a educação passou a ser desafiada a uma nova realidade, profissionais da educação em conjunto com os pais e responsáveis, procuraram uma forma de tentar minimizar o tamanho impacto ocasionado com a pandemia. Sendo assim, houve a implantação de uma nova metodologia de ensino, a chamada "educação remota emergencial”, a qual foi o único meio cabível encontrado, para dar continuidade à educação de forma não presencial durante esse período. Educação essa que mesmo em meio a todos os desafios propõem de formas diferentes, maneiras de abrangência a todos os públicos escolares, tendo em vista que muitas famílias não conseguem fazer esse acompanhamento de forma remota.

Os educadores tiveram que aprender uma nova forma de educar, usando a tecnologia como sua aliada nesse processo de forma síncrona e assíncrona, ou em outras plataformas digitais como WhatsApp, aprendendo de forma rápida e sem nenhuma instrução, um modo novo de educar e passar a mediar conhecimento. Sabendo que a educação remota difere da educação à distância. Corroborando os autores Hodges et al. (2020) quando afirmam que a educação remota online digital se diferencia da Educação a Distância pelo caráter emergencial que propõe usos e apropriações das tecnologias em circunstâncias específicas de atendimento onde outrora existia regularmente a educação presencial.

É de suma importância ressaltar que os professores sem tempo de aprendizagem ou adequação a teoria alguma e de forma abrupta passaram a ter que utilizar as mídias como pressupostas e ferramenta essencial de aprendizagem, tendo acarretado diante dos desafios, muitos problemas psicológicos, emocionais e sociais 
diante desse processo de uso das ferramentas como foco principal do ensino aprendizagem.

Fora chegado o momento em que os professores estavam sobrecarregados, por apresentarem outras responsabilidades fora a de prestar o suporte educacional para os filhos, como afazeres domésticos, perda dos horários, rotinas, e foco no processo de planejamento e tempo de oportunizar seus estudos, dentre outro a interação fora dos horários, ligações, reuniões e formações virtuais ou até mesmo trabalho externo. Logo, como consequência, este fator pode ter sido a chave para o desenvolvimento de prováveis transtornos psicológicos, como um sentimento de baixa autoestima, ansiedade, medo, depressão ou então de incapacidade por parte dos educadores, dentre outras lamentações e problemas desenvolvidos nesse período, tendo a gestão da escola, uma sensibilidade de está nessa caminhada dando suporte e acolhimento, orientando esse professor para que os danos fossem minimizados. Tutoriais foram descritos, auxílios e atividades foram compartilhados, suporte e diálogos acerca de melhores processos tecnológicos foram explanados para que os professores se sentissem confortáveis diante dessa nova realidade. A gestão foi a muleta para que a educação pudesse caminhar sem muitos impasses e esteve e está ao lado dos professores, pais e alunos ao longo de toda essa caminhada estreitando os grandes percalços da educação remota.

\section{Ações sociais escolares na comunidade escolar} da escola José Assis e seus reflexos positivos na busca da participação e interação familiar

Diante da nova realidade vivenciada pela escola, houvesse um diálogo acerca do que poderia ser feito 
para aproximar as famílias e os alunos das aulas remotas, para que não se distanciasse diante das dificuldades que surgiriam nesse processo de fechamento, pois se sabe quem muitas famílias que não possuem suporte financeiro, viam a escola como uma aliada no processo de alimentação dos filhos, além de todo o amparo social, emocional e cognitivo. Foram longos diálogos acerca de projetos respeitando todos os protocolos estabelecidos pela Pandemia, para irem criadas redes de ajuda às famílias que não tinham como caminhar junto à escola nesse processo.

A escola viabilizou atividades impressas elaboradas pelos educadores, revisadas pelos coordenadores, para que essas famílias pudessem pegá-las na escola e mesmo que não tivessem acesso à internet, poderiam estar sem perder o vínculo com o aprendizado das crianças. Embora saibamos que a grande dificuldade no processo de resolução dessas atividades, porém fora pensado dessa forma no intuito de encurtar os prejuízos que já serão irreparáveis em um possível retorno.

Fora criada uma grande rede de sensibilização e amparo às famílias que mais necessitavam, contando com a ajuda de várias pessoas que faziam nem sequer parte da escola ou da área da educação, mas se sensibilizaram com as falas dos gestores diante da realidade posta nesse momento difícil, sendo oportuno explanar a entrega de quentinhas para as famílias da comunidade escolar, doações de alimentos, momentos de sopão e entrega de máscaras, álcool em gel, momento de fala e escuta as famílias em observação e ajuda psicológica diante de todos os fatos que eram por eles colocados. Momentos de oração em redes sociais, lives educativas para professores, pais e alunos, kits de suporte aos alu- 
nos contendo alguns materiais necessários para que os mesmos fizessem as atividades, dentre outras ações que demandaram planejamento, busca e dedicação por parte de todos que compunham a gestão desta escola.

A escola diante das doações receberá inúmeros depoimentos, sendo pertinente ressaltar a fala da mãe da Letícia Cunha de Araújo, aluna do 2.0 ano de nossa escola, onde revela que não tinha nada para jantar quase todas as noites e que o sopão ajudou em muitos dias de aflição.

É perceptível que a escola de formas diferenciada tentou acomodar e acolher sua comunidade para não as deixa-lá desassistida, considerando as fragilidades, os anseios, medos e a falta de conhecimento onde os pais apresentavam, os mesmos, orientados e instruídos, tendo como pressuposto a proximidade dessas famílias com a escola em todo o período de afastamento das aulas presenciais.

\section{Considerações finais}

O presente artigo traz uma reflexão acerca dos problemas causados com o fechamento das escolas devido à pandemia da Covid -19 e suas nuances diante do processo de ensino aprendizagem, na EMEIEF José Assis de Oliveira, bem como expõe as dificuldades encontradas durante esse período por educadores, gestão, pais e alunos para adequar-se a nova maneira de ensino.

Sabendo-se que ao longo de todo o processo da pandemia puderam ser minimizados muitos problemas sendo dadas muitas soluções diante do fato observado pela escola de como algumas famílias estavam vivenciando esse processo e o olhar sensível nesse momento foi peça fundamental para que essas famílias não desis- 
tissem, não só em não perder o vínculo com a escola, mas em continuar a luta pela sobrevivência.

Foram dias muito difíceis e por inúmeras vezes a escola foi amparada por doações de pessoas que não tinham vínculo com a mesma e contribuem diante das falas da realidade vivenciada, chamadas anjos sem asas, por estarem de forma voluntária contribuindo para que o sofrimento fosse estreitado naquele momento de tanta vulnerabilidade.

Ao longo de todo o isolamento a gestão incansavelmente procurou em todos os momentos não desampararem a comunidade e com todos os movimentos proporcionados pela união da gestão em busca de amparo, percebeu-se a alegria e gratidão das famílias para com a escola, sendo válido todo o esforço e dedicação em está ao lado para que o processo fosse sentido de forma branda, sendo importante expor o quanto é fundamental a escola e a comunidade estarem em parceria, ambas sendo um suporte para a outra, para haver equidade na qualidade do percurso escolar.

O trabalho diário da EMEIEF José Assis de Oliveira busca a excelência do serviço público e o respeito a todos os que de forma direta e/ou indireta fazem o cotidiano desta grande escola, repleta de desafios, mas primeiro, de boa vontade para oportunizar aos seus educandos um futuro promissor, com base em ações no presente que colaborem para ele realizar seus sonhos e mantenha sempre acesa a chama da esperança.

\section{Referências}

BOTO, Carlota. A educação e a escola em tempos de coronavírus. Jornal da USP, ano 2020. Disponível em: https://jornal.usp.br/artigos/a-educacao-e-a-escola-em-tempos-de-coronavirus/. Acesso em: 31 mai. 2020. 
CENTO DE INOVAÇÃO PARA A EDUCAÇÃO BRASILEIRA (CIEB). Planejamento das Secretarias de Educação do Brasil para Ensino Remoto. 3 de abril de 2020 (v8). Disponível em: https://cieb.net.br/wp-content/uploads/2020/04/CIEB-Planejamento-Secretarias-de-Educac\%C3\%A3o-para-Ensino-Remoto-030420.pdf. Acesso em 28 jul. 2020.DOURADO, Luiz Fernandes. Políticas e gestão da educação básica no Brasil: Limites e perspectivas.Educ. Soc., Campinas, vol. 28, n. 100 - Especial, p. 921-946, out. 2007.

EDUCAÇÃO NA PANDEMIA: ensino a distância dá importante solução emergencial, mas resposta à altura exige plano para volta às aulas. Site Todos Pela Educação, ano: 2020. Disponível em: https://www.todospelaeducacao.org.br/con-teudo/Educacao-na-pandemia.

FREIRE, Paulo. Pedagogia da autonomia: saberes necessários á prática educativa. SP: Câmara brasileira do livro, 1996.

HODGES, Charles et al. The difference between emergency remote teaching and online learning. EDUCAUSE Review. 27 mar. 2020. Disponível em: https:// er.educause.edu/articles/2020/3/the-difference-between-emergency-remote-teachingand-online-learning, 2020. Acesso em: 11 maio 2020.

KENSKI,VM.(2012). Educação e tecnologias: o novo ritmo da informação. Campinas: Editora Papirus.

SENHORAS, E. M. Coronavírus e Educação: Análise dos impactos assimétricos. Boletim de Conjuntura (BOCA), vol. 2, n. 5, 2020. 


\section{O volume 01 Líderes que Transformam: Novos}

paradigmas de gestão na educação, da coleção Fa-

cesma, aborda a temática da Inteligência Emocional, em referência a inspiração da Professora Sueli dos Santos Leitão, na disciplina Assessment, Coaching e Mentoring.

Este livro nasceu a partir do incentivo da referida professora em seu valoroso trabalho junto à turma de MBA em Gestão Educacio-

nal e Financeira no Setor Público e Privado da Faculdade Cesma de Maracanaú - FACESMA, ao provocar o protagonismo literário para juntos escrevermos as nossas práticas. Uma ação realizada pela Professora Rita Cristiane de Oliveira Gomes, Diretora Acadêmica, que com sua visão empreendedora, dedicou todo o apoio e incentivo para que chegássemos à publicação desta obra. Entre seus feitos, está a reunião de um time de profissionais de excelência na área da educação, como organizadores desta coletânea, e que dedicaram arduamente seus saberes para a construção do conhecimento coletivo, aqui ofertado aos nossos leitores. A professora Maria Eliene Magalhães da Silva, que ministrou a disciplina de Metodologia Científica, nestas trilhas podemos contar com a Organizadora Professora Luciana Mascena Silva - Secretaria Acadêmica, com o Orientador Professor Iury Torquato de Almeida - Coordenador do Curso de Administração e com a Professora Dolores Raissa Teixeira Cunha no campo da revisão geral.

Assim, conduzimos por meio da escrita, nossas vivências profissionais na educação, levando para o mundo reflexões, aprendizados, ações para pensar e sentir o ato de ensinar. Não temos aqui, a pretensão de transferir conhecimento, mas de apresentar uma aventura criadora, onde tornamos viável a aceitação de novos paradigmas, que nos traz esperança de um novo alvorecer, ainda que em tempos tão desafiadores.

É nessa esperança do aprender e ensinar, que esta coleção nos motivará, tornando real o registro de nossos saberes e fazeres na Facesma e no mundo, diante do que hoje vivemos no cenário político, educacional, econômico e social, que nos impulsionam a vivenciar rupturas, descobertas, mudanças, inovações, diálogos, discussões e quebra de paradigmas, nos quais relatamos os desafios apresentados e as respostas adotadas no enfrentamento à pandemia da Covid-19 (SARS- CoV-2), em que nós, docentes e discentes, de forma coletiva vivenciamos mudanças e inovações no formato online, sobre às quais dedicamos a construção desta obra, tornando-nos autores e autoras de novos rumos na gestão educacional.

Dolores Raissa Teixeira Cunha

Luciana Mascena Silva

FACESMA

Iury Torquato de Almeida

Maria Eliene Magalhães da Silva

Rita Cristiane de Oliveira Gomes

Sueli dos Santos Leitão 